INTERVENTIONS: NEW STUDIES IN MEDIEVAL CULTURE ETHAN KNAPP, SERIES EDITOR 


\title{
Imagining the Parish in Late Medieval England
}

\author{
Ellen K. Rentz
}


Copyright () 2015 by The Ohio State University.

All rights reserved.

Library of Congress Cataloging-in-Publication Data

Rentz, Ellen K., 1978-

Imagining the parish in late medieval England / Ellen K. Rentz. — 1 [edition].

pages $\mathrm{cm}$. - (Interventions: new studies in medieval culture)

Includes bibliographical references and index.

ISBN 978-0-8142-1275-2 (cloth : alk. paper) - ISBN 978-0-8142-9380-5 (cd-rom)

1. England-Church history-1066-1485. I. Title.

BR750.R46 2015

$282^{\prime} \cdot 420902-\mathrm{dc} 23$

2014041735

Cover design by Laurence J. Nozik

Text design by Juliet Williams

Type set in Adobe Minion

Printed by Thomson-Shore, Inc.

Cover Image: Priest addressing a congregation. Omne Bonum, entry for Excommunicacio [Excommunication]. () The British Library Board, Royal 6 E VII (c. 1350-75), fol. 75v. The image is not the original version.

(0) The paper used in this publication meets the minimum requirements of the American National Standard for Information Sciences-Permanence of Paper for Printed Library Materials. ANSI Z39.48-1992.

$\begin{array}{lllllllll}9 & 8 & 7 & 6 & 5 & 4 & 3 & 2 & 1\end{array}$ 
In honor of Ellen Brown Rice

In memory of Betsey Rice Ketels 


\section{CONTENTS}

List of Illustrations ix

Acknowledgments $x i$

List of Abbreviations xiii

Introduction $\quad 1$

Chapter 1 At the Font and in the Grave: The Fabric of Parochial Identity 8

Chapter 2 Parochial Penance and the Making of the Parish 33

Chapter 3 The Parish on Its Feet: Lay Devotion and the Metaphor of Walking 64

Chapter 4 Working the Land, Working the Spirit: Agrarian Metaphor and Spiritual Community $\quad 91$

Chapter 5 Reading the Prick of Conscience in the Parish 122

Epilogue How Do I Save My Soul? 149

Bibliography 155

Index 177 


\section{ILLUSTRATIONS}

\section{FIGURES}

1 Mass helps souls in Purgatory (c. 1460-70) 20

2 Churchyard burial scene (c. 1420-30) 27

3 Priest addressing a congregation (c. 1350-75) 44

4 The Trotton Doom (c. 1380-90) 89

5 The Luttrell household at dinner (c. 1330-45) 96

6 The Prick of Conscience Window (c. 1410-20) 123

7 "Of pe relefyng of saules in purgatory" (c. 1460-70) 129

8 The Prick of Conscience Window, buildings fall (c. 1410-20) 135

9 The Prick of Conscience Window, terrified penitents (c. 1410-20) 136

10 The Corporal Works of Mercy Window (c. 1410-35) 140

11 The Blackburn Window (c. 1412-35) 142

\section{PLATES}

1 Plowing (c. 1330-45)

2 Sowing; Psalm 94 (c. 1330-45) 
x - illustrations

3 Harrowing; Sir Geoffrey's shield (c. 1330-45)

4 Clod-breaking; clerics with scroll (c. 1330-45)

5 Weeding (c. 1330-45)

6 Reaping (c. 1330-45)

7 Stacking sheaves (c. 1330-45)

8 Cart full of sheaves (c. 1330-45)

9 Clerics at a lectern (c. 1330-45) 


\section{ACKNOWLEDGMENTS}

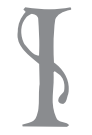

could not have written this book without advice and encouragement from so many people, and it is an honor to thank them here. This project began as a dissertation, and I owe a special debt of gratitude to Susan Crane, Paul Strohm, and Helen Barr for all of their help in framing and developing it and for their thoughtful guidance as it evolved. I would also like to extend my warmest thanks to Robert Hanning, Sandra Pierson Prior, and the members of the Columbia Medieval Guild.

I am extraordinarily grateful to a number of friends and colleagues who have helped along the way, including Patricia Akhimie, Elizabeth Allen, Michael Calabrese, Ian Cornelius, Christine Crockett, Rebecca Davis, Andrea Denny-Brown, Erika Dyson, Karen Emmerich, Jennifer Garrison, Shannon Gayk, Lily Geismer, Ghenwa Hayek, Jen Jahner, Ashby Kinch, Shayne Legassie, Seth Lobis, Asifa Malik, Brenna Mead, Rosemary O’Neill, Raquel VegaDuran, and Tamara Venit-Shelton. I would like to thank all of my colleagues in the Literature Department at Claremont McKenna College for their help and encouragement, and I am especially grateful to John Farrell for reading a complete draft of the manuscript. I must also thank the Gould Center for Humanistic Studies, the Faculty Research Committee, and the Office of the Dean of the Faculty for supporting my research. 
It has been such a pleasure working with the Ohio State University Press, and I would like to thank Ethan Knapp, Malcolm Litchfield, Eugene O'Connor, and Tara Cyphers for all of their hard work in bringing this project to completion. I must also express my deep gratitude to the two readers for the Press, whose thoughtful and incisive suggestions made this a better book.

Parts of this study have appeared in earlier forms in Yearbook of Langland Studies 25 (2011) and Studies in Iconography 31 (2010) (copyright () held by Studies in Iconography). I thank the editors of both journals for their permission to present adapted versions of this material here.

I am most grateful to my family, and I would like to thank my father, Marty Ketels, for his admirable work ethic, his unflagging enthusiasm, and his goofy sense of humor. And of course my husband, David Rentz, whose love and generosity are without measure. 


\title{
ABBREVIATIONS
}

\author{
EETS Early English Text Society \\ e.s. extra series \\ o.s. original series \\ MED Middle English Dictionary. Ed. Hans Kurath and Sher- \\ man M. Kuhn. Ann Arbor: University of Michigan Press, \\ 1952-2001. http://quod.lib.umich.edu/m/med/ \\ OED Old English Dictionary. 2nd ed. Oxford: Oxford Univer- \\ sity Press, 1989. http://www.oed.com/
}

\section{Note}

When quoting from the Bible, I have used the New Revised Standard Version (NRSV). I use Vulgate numeration when quoting from the Psalms. When offering quotations in Middle English, I have silently omitted the square brackets that various editors use to indicate variant readings or expanded abbreviations; when square brackets do appear, they enclose material that I have either added or amended, with glosses of difficult Middle English words appearing in italics. Many of the glosses that I offer for words and phrases from Piers Plowman have been reproduced from Schmidt's 1995 edition of the poem. Unless otherwise indicated, translations are my own. 


\section{INTRODUCTION}

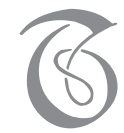

his is a book about the parish-not one particular parish, but the parish as an idea. In medieval parlance, "parish" was an umbrella term that encompassed not only the physical space of the parish church and its churchyard but also the congregation and even the district in which its members lived. ${ }^{1}$ But the parish was also a model of the ideal spiritual community and the eternal community of heaven. It offered a framework for negotiating the relationship between individual, community, and God, and it also shaped the way medieval people thought about time and about the relationship between the living and the dead.

1. Although Chaucer makes a clear distinction between parish and parishioner-"parisshe" and "parishen"-in the General Prologue to the Canterbury Tales, the two words are used interchangeably by most authors. According to the Middle English Dictionary, the words parish and parishen can be used to refer to both parishes and parishioners, and distinguishing between the two can be extremely difficult (see the entries for "parish," n.; and "parishen," n.1 and n.2). Both "parish" and "parishen" are in wide use in the fourteenth century, but the term "parishioner" does not appear until the fifteenth century ( $M E D$, "parishioner," n.). Parishioners were also frequently described as "evenCristen" (MED, "even," adj., 16c). Kümin discusses the problem of terminology in Shaping of a Community, 2. 
Collective worship and the life of the parish mattered deeply to laypeople, and both loom large in late medieval visual and vernacular culture.

It may seem obvious, given the ubiquity of parish churches across medieval England (upwards of 9,000 by about 1200), ${ }^{2}$ that the parish would be a central site and subject of Middle English literature. But far more historians than literary scholars have given their attention to these sites of social organization. For many generations, the parish was viewed solely as an index of post-Lateran and pre-Reformational compliance and change; studies were generally angled toward the sixteenth century, the growth of lay organization, and the rise of Protestantism. ${ }^{3}$ More recently, however, a number of scholars have focused on the parish in its own right. Eamon Duffy championed the parish in Stripping the Altars: Traditional Religion in England, 1400-1580, a sweeping account of lay devotion that, in turn, paved the way for several important regional studies of the parish. ${ }^{4}$ Both Peter Brown and Katherine French have made meticulous use of a large body of documentary evidencechurchwardens' accounts, episcopal registers, guild records, wills-in order to examine many aspects of late medieval piety, religious practice, and lay organization. ${ }^{5}$ French, in particular, has given us a much better sense of the import of the parish in the lives of laypeople, especially women, and their involvement in its upkeep and maintenance. ${ }^{6}$ Middle English literature often factors into historical studies of the parish, but too often it is used principally to illustrate and affirm the data gleaned from other kinds of documents.

In drawing attention to the parish imaginary, I assemble a somewhat heterogeneous collection of Middle English texts, including sermons, handbooks, and liturgical texts as well as narrative poetry, exempla, and drama. I also explore a range of visual sources, including manuscript illuminations, parish wall paintings, and stained glass. What motivates this diverse array of texts and images is the conviction that they operate at parish level, whether they were produced expressly for lay readers, listeners, or viewers, or for parish priests looking to better educate the laypeople in their care. They all grapple in different ways with questions related to parochial identity and the importance of collective worship. They are intensely concerned, moreover, with the extent to which salvation might be a collective enterprise.

2. Swanson, Church and Society, 4 .

3. French provides an overview of early approaches to the parish in the introduction to People of the Parish, 15-17.

4. In recent decades, a number of important monographs and essay collections have appeared: French, Gibbs, and Kümin, eds., Parish in English Life; Burgess and Duffy, eds., Parish in Late Medieval England; Kümin, Shaping of a Community.

5. Brown, Popular Piety; French, People of the Parish.

6. French, Good Women of the Parish. 
Their parish-orientation also means they are fundamentally concerned with the negotiation of public life-the parishioner both in the nave and out in the world-and they ask their readers, listeners, and viewers to imagine and understand themselves not just as individuals seeking reconciliation with God but as members of a much broader community. We should not assume, of course, that the parish was a place in which sermons and pastoral handbooks were delivered verbatim or followed to a tee. Parishioners were not, as Emma Mason observed decades ago, "dutifully programmed automatons." Indeed, the texts and images that I consider offer much more than a reflection of what the parish looked like or what took place in it. As Paul Strohm reminds us, "only rarely can we expect [texts] to tell us 'what happened, or to contribute materially to our factual base. They offer crucial testimony on other, though no less historical, matters: on contemporary perception, ideology, belief and-above all—on the imaginative structures within which fourteenth century participants acted and assumed that their actions would be understood." As actors in and products of a dense network of perceptions, discourses, experiences, and practices, the texts, images, and objects that I consider in this book are "vehicles of conception" that order and construct the parish. ${ }^{10}$

It is surprising that the parish has not been more central to the study of late medieval lay devotion and vernacular theology. In a seminal essay that appeared in Speculum in 1995, Nicholas Watson drew special attention to the study of late medieval English religious culture and, more particularly, to the aftermath of the imposition of Archbishop Thomas Arundel's repressive Constitutions in 1409, an event that, to Watson's mind, imposed a deadlock on the production of vernacular theological writing. Defining "vernacular theology" as "any kind of writing [. . . ] that communicates theological information to an audience," he focused almost exclusively on works written between 1350 and 1450 and deliberately excluded drama, saints' lives, and most sermons in order to limit his focus to "more intellectually challenging texts." ${ }^{11}$ In more

7. Mason, "Role of the English Parishioner," 17.

8. Strohm, Hochon's Arrow, 4.

9. Geertz, Interpretation of Culture, 212. Pocock describes a text as "an event as well as a framework within which further events occur" in "Texts as Events," 22. For Barr, language is "a form of social behavior," a mode "not just of writing or speaking, but of doing," Socioliterary Practice, 1, 7. See also Strohm, "What Happens at Intersections?" 223-32.

10. Binski has argued that "the parish church was in part a vehicle of communication" and that its images "had a constitutive, rather than representational, role in the making of religion itself." "English Parish Church," 18, 3.

11. Watson, "Censorship and Cultural Change," 823. Gillespie expands Watson's more limited categorization of the field in "Vernacular Theology," 401-20. 
recent years, however, scholars have expanded the disciplinary and literary parameters of vernacular theology to include a wider variety of texts-drama, liturgical texts, sermons-and a broader range of questions about their performative, poetic, and imaginative potential..$^{12}$

Texts falling under the broad rubric of vernacular theology are often associated with self-examination and self-correction, and a number of recent studies draw special attention to literature derived from the cloister. For Nicole Rice, late medieval prose spiritual guides enable ambitious readers to take up the self-discipline of the professional religious rule. ${ }^{13}$ Jennifer Bryan argues that Middle English devotional literature is more fundamentally concerned with selfhood and interiority, prompting its readers to turn inward in order to see and behold themselves. ${ }^{14}$ This book aims instead to show how Middle English devotional literature engages with questions of collective worship and community. Like other studies, my book positions late medieval devotional literature in relation to the pastoral reforms that followed the promulgation of the Fourth Lateran Council in 1215. Throughout the thirteenth and fourteenth centuries, the Council's call for reform was met with an outpouring of catechetical treatises and penitential handbooks, all aimed in different ways at improving the spiritual health of the laity. ${ }^{15}$ Late medieval Christians wanted to know how to go about ensuring their salvation at the end of time. Indeed, this is one of the driving questions of Piers Plowman: "How do I save my soul?"16 I argue that, in seeking to answer the question that was on every Christian's mind, vernacular theology emphasizes not only the importance of collective devotion but the idea that salvation is best achieved through the ritual life of the parish, alongside one's even-Cristen. Kneeling in the nave during the Mass, many English laypeople would have been able to see a Last Judgment painting looming above them on the chancel arch. With the damned on the left and the saved on the right, such an image-what Pantin called "a sermon in itself"-reminded viewers of the two outcomes that awaited them. ${ }^{17}$ Even more importantly, however, it articulated the relationship between parochial

12. See especially the cluster of essays on the topic of vernacular theology and medieval studies in Holsinger, ed., "Literary History and the Religious Turn," a special issue of English Language Notes.

13. Rice, Lay Piety and Religious Discipline.

14. Bryan, Looking Inward.

15. See especially Pantin, English Church, 189-243; Boyle, "Fourth Lateran Council," 30-44; Shaw, "Influence of Canonical and Episcopal Reform," 44-60; Woods and Copeland, "Classroom and Confession," 376-406.

16. "Teche me no tresor, but tel me this ilke- / How I may save my soule." Langland, Vision of Piers Plowman: A Critical Edition of the B-Text, ed. Schmidt, 1.83-84.

17. Pantin, English Church, 239. 
practice and future salvation, between the ritual life of the parish and the eternal life of the saved.

In turning my attention to collective parochial worship, I focus on a number of texts that, despite their popularity among medieval readers, continue to be sidelined in modern scholarship, even by scholars working in the field of vernacular theology. The Prick of Conscience, by all accounts a medieval bestseller, ${ }^{18}$ has been described but rarely interpreted or analyzed. ${ }^{19}$ This is also largely true for John Mirk's Festial ${ }^{20}$ and the anonymous Northern Homily Cycle. ${ }^{21}$ Robert Mannyng's Handlyng Synne, a veritable reservoir of stories, has garnered more attention than most, particularly in recent decades, and yet its emphasis on the parish has been largely overlooked. ${ }^{22}$ And the Lay Folks Mass Book has received almost no interest from literary scholars, despite the fact that it is filled with vernacular prayers and the rich descriptions of parochial practice that historians often cite. I bring peripheral texts to the fore but I also put them in conversation with the visual and material culture of the parish, from the baptismal font and the churchyard grave to wall paintings and stained glass. ${ }^{23} \mathrm{I}$ also set these texts and images in conversation with more canonical works such as Piers Plowman, a poem that is itself deeply committed to thinking about spiritual community and religious practice. ${ }^{24}$ Middle English literature raises important questions about the nature and function of parochial worship and about what it meant to be a parishioner. In considering such a wide-ranging combination of texts and

18. The poem survives in more than 100 manuscripts. Raymo, Manual of the Writings, 2268. Lewis pointed out the problem of neglect several decades ago in "Medieval Popularity, Modern Neglect," 3-8. Sargent considers the poem's transmission in the fourteenth and fifteenth centuries in "What Do the Numbers Mean?" 218-21.

19. Notable exceptions include Chickering, "Rhetorical Stimulus," 191-230; and Fitzgibbons, "Enabled and Disabled 'Myndes," 72-94.

20. As Ford puts it in a recent book-length study of the Festial, Mirk's sermon collection "offers an unrivaled opportunity to study late fourteenth-century Christianity as it was expounded to the ordinary, rural men and women who comprised the majority of the English population." John Mirk's Festial, 13.

21. Apart from Morey, who has explored the Northern Homily Cycle in its legal and literary contexts, studies of the collection have focused almost exclusively on its textual sources and affiliations: see Morey, "Legal and Spiritual Sanctuary," 326-35.

22. A handful of recent studies focus on Mannyng's treatment of the relationship between priests and laypeople. See especially Greenspan, "Lessons for the Priest," 109-21; Hasenfratz, "Terror and Pastoral Care," 132-48; Garrison, "Mediated Piety," 894-922.

23. Parish art has been the subject of much recent work. Kamerick discusses the visual culture of the parish and the important role that images played in lay devotion. Popular Piety and Art, 69-105. See also Stanbury's wide-ranging exploration of late medieval visual culture in Visual Object of Desire.

24. Benson suggests that Langland may have drawn on the "common artistic grammar" and "familiar" iconography of parish wall paintings in Public "Piers Plowman," 164. 
images, this book aims to enrich our understanding of why the parish and the ideal of collective worship mattered to late medieval laypeople. I seek to understand, moreover, the role that vernacular literature plays in articulating and shaping this ideal, and the extent to which it invites readers themselves to enter into the process of imagining and constructing the parish.

I begin where all parishioners began their lives in the church: at the font. I begin, too, in the churchyard, where earthly life ended but where deceased parishioners entered the extended community of the living and the dead. Chapter 1 argues that late medieval sermonists (the anonymous author of the Northern Homily Cycle, for example, or John Mirk in his Festial) sought to shape lay expectations about religious identity and experience by turning to two tropes, font and churchyard grave, that offered a means of exploring how the parish articulated itself. Both are closely associated with the capacious concept of kynde, especially in Handlyng Synne and Piers Plowman, where they provide a staging ground for the performance and renewal of parochial identity. Continuing with the sacramental life of the parish, chapter 2 explores penitential practice and argues that, after 1215, confession became a fundamentally parochial and, more particularly, collective enterprise. Later medieval liturgical prayers such as the Confiteor-widely available in vernacular translation-emphasize the distinctly parochial contexts of penance while also framing the Mass in collective penitential terms. Literature certainly draws on liturgy and doctrine, but it is also keenly attentive to the symbolic role that parochial space plays in the life of the penitent. Looking at sermon exempla from Handlyng Synne, I argue that, in order to illustrate the efficacy of parochial penance, Mannyng concentrates on its physical setting, paying particular attention to the role that parochial thresholds-the churchyard gate, the church door-play in repelling the devil and compelling the layperson from sin to salvation. I then explore the more beleaguered parish of Langland's Piers Plowman, a parish whose walls are vulnerable to outside attack and the infiltration of profit-seeking friars. Throughout the poem, Langland uses the metaphor of horticultural grafting to emphasize the friars' physical violation of the parish and its practices.

Chapters 3 and 4 examine two powerful metaphors for lay devotion and the work of getting saved: walking and labor. In the context of the parish, the layperson's spiritual progress is often figured as a kind of pedestrian journey, however halting or slow. I begin by demonstrating that walking was itself a medium of religious experience in the parish: parochial processions brought a congregation to its feet, all walking together toward salvation. I also explore the long tradition-going back to Augustine's description of love as the foot of the soul-of associating charity and the avoidance of sin with pedestrian 
movement in sermons, handbooks, and visual art. In chapter 4, I explore the motif of agricultural labor, which offered a lexicon for exploring the collective and cooperative nature of medieval devotion. Manual labor is used in such texts as the Northern Homily Cycle to describe not only penance and charity but also pastoral care. Priests are cast as farmers who till the word of God, and laypeople the day laborers who do God's work. In the well-known agricultural sequence in the Luttrell Psalter, images of manual labor are paired with images of singing clerics in order to draw an analogy between working the land and working the spirit, and in order to shape the extended members of the Luttrell household into a spiritual enterprise. Langland takes up many of these concerns in Piers Plowman, and I argue that he invokes the language of agricultural bylaws in order to explore spiritual community on the half-acre.

Although this is a book about how vernacular literature explores the idea of the parish, the fifth and final chapter considers how one particular parish-All Saints, North Street in York-used vernacular literature to imagine itself. The so-called Prick of Conscience Window is best known for its Middle English quotations from the Prick of Conscience, but I argue that, beyond merely citing and illustrating the poem, the window adapts it for a parochial audience. By interpolating the poem directly into the ritual life of the parish, the window makes vernacular reading a tool of parochial worship and, ultimately, a means to salvation. 


\title{
1 \\ At the Font and in the Grave
}

\author{
The Fabric of Parochial Identity
}



hen Langland's dreamer meets Holy Church at the beginning of Piers Plowman, he has no idea who-or what-she is. "Thanne hadde I wonder in my wit what womman she weere," he says, "That swiche wise wordes of Holy Writ shewed." He greets her in a formal way-he "halsede hire on the heighe name"-as he would a total stranger. ${ }^{1}$ As it turns out, however, he and Holy Church have a long history together. "Thow oughtest me to knowe," she says,

I underfeng [received] thee first and the feith taughte.

Thow broughtest me borwes [pledges] my biddyng to fulfille,

And to loven me leelly [loyally] the while thi lif dureth. ${ }^{2}$

You ought to know who I am, she scolds, because I baptized you. And yet, even though Will has made a lifelong commitment to her, he does not know who she is.

1. Langland, Vision of Piers Plowman: A Critical Edition of the B-Text, ed. Schmidt, 1.71-73. Unless otherwise indicated, all Piers quotations are taken from this edition of the B-text, hereafter referred to as Langland, Piers Plowman.

2. Ibid., $1.75-78$. 
Holy Church constitutes one of the poem's most expansive concepts, a capacious "entity", in Galloway's formulation, that encompasses church doctrine, textual authority, the apostolic tradition, and sacramental theology. ${ }^{3}$ The encounter between Holy Church and Will has been explored from a wide variety of perspectives, particularly in relation to philosophical and homiletic traditions, gender discourse, and theories of allegory and language. ${ }^{4}$ As the personification of Ecclesia, she represents church authority, ${ }^{5}$ but she also figures the church more broadly, including its congregation, its practices, and the material spaces and objects through and in which the church constituted itself. The local parish is perhaps also one of Holy Church's many facets. Indeed, as Galloway reminds us, Langland's figure of Holy Church evokes John Thoresby's mid-fourteenth-century definition of the "holy Catholic church" as an entity consisting of "the congregation and the communion of the faithful" and "the sacraments of the church and other things by which the Christian church communes." I want to suggest that Will's failure to recognize Holy Church draws attention to the ritual, material, and spatial aspects of parochial identity. His confusion may stem at least in part from the fact that Holy Church exhibits none of these features when he encounters her; in personified form, she lacks the very spaces, objects, and practices through which medieval laypeople experienced religion. We might compare Will's early encounter with Holy Church with his later encounter with Thought, another personification whom Will is unable to recognize:

3. Galloway, Penn Commentary, 148. In exploring Langland's episodic treatment of Holy Church, I am indebted to Anne Middleton's discussion of the poem's form, particularly her suggestion that Langland constructs "chains of ideational association" that link episodes and ideas together across the poem. "Narration and the Invention of Experience: Episodic Form in Piers Plowman," 96.

4. Galloway provides a brief introduction to some of these approaches in Penn Commentary, 148-50. On the Latin poetic tradition that undergirds Langland's figure of Holy Church, see Piehler, Visionary Landscape: A Study in Medieval Allegory, 31-68; Paxson, Poetics of Personification, 8-34; Raskolnikov, Body against Soul: Gender and Sowlhele in Medieval Allegory, 33-50. On the speech of Holy Church and its relationship with contemporary sermon-writing, see Wenzel, "Medieval Sermons," 165-67. Simpson observes that Holy Church "uses the homiletic, didactic style we might expect of the authority figure in an oraculum," but he warns that her sermon-like speech cannot be characterized as the kind of instruction offered in the manuals that proliferated in the centuries following the Fourth Lateran Council of 1215. "Piers Plowman": An Introduction to the B-Text, 25-28. For a discussion of Holy Church and the broader topic of gender personification, see Cooper, "Gender and Personification in Piers Plowman," 32; Paxson, "Gender Personified," 65-96.

5. Raskolnikov, Body against Soul, 173. Hanna suggests that Holy Church "evokes the fraught correction of the grammar master." "School and Scorn: Gender in Piers Plowman," 223.

6. As Galloway observes in Penn Commentary, 149; Lay Folks' Catechism, 25 (lines 416-20). 
A muche [tall $]$ man, as me thoughte, lik to myselve,

Cam and called me by my kynde name.

"What art thow," quod I tho, "that thow my name knowest?"

"That thow woost wel," quod he, "and no wight bettre."

"Woot I," quod I, "who art thow?" “Thought," seide he thanne.?

As Smith has recently observed, Will has trouble recognizing Thought because thought requires thinking: "It is not surprising that the narrator cannot recognize thought as a substance [. . .] because it is the very means by which he recognizes, or conjures, thought." ${ }^{\prime 8}$ Holy Church is not something entirely external to the dreamer, or to any Christian for that matter-instead, it is actively constituted by way of ritual participation in and through the material space and fabric of the church. Will fails to recognize Holy Church because church is, like thought or thinking, a practice-something one does. And in late medieval England, it was something one did in the parish church. Indeed, Holy Church's appearance as a person may be what makes her the most unintelligible: she lacks the ritual and material features that were so central to the medieval church and to the layperson's experience of it. In personified form, she looks nothing like the conglomeration of practices, spaces, and people that constituted the church.

When the dreamer thinks of Holy Church later on, however, he does so in the context of a heated conversation about burial location, and he associates Holy Church with parochial space and ritual. The moment of recollection occurs in passus 11, when Will dreams that he is an old man faced with making his last confession and choosing his place of burial. Although Lust of the Flesh and Covetise of Eyes encourage him to work out a deal with the friars, he decides not to be buried at the friary but rather in his own parish:

And tho fond I the frere afered [afraid] and flittynge [changeable] bothe Ayeins [against] oure firste forward [agreement], for I seide I nolde

Be buried at hire hous but at my parisshe chirche

(For I herde ones how Conscience it tolde

That there a man cristned were, by kynde he sholde be buryed). ${ }^{9}$

7. Langland, Piers Plowman, 8.70-74.

8. Smith, "Negative Langland," 46-47. Moreover, as Kay observes, thought is a faculty of the mind and therefore has no literal place. Place of Thought, 8. Paxson contends that Will's failure to recognize Holy Church is a familiar "narratological formula" apparent every time he meets (and subsequently fails to identify) a personification. Poetics of Personification, 124-26.

9. Langland, Piers Plowman, 11.63-67. 
Angered that the friars care more about burial than baptism, his mind is drawn to Holy Church once more:

$\mathrm{Al}$ for tene of [distress at] hir text trembled myn herte, And in a weer gan I wexe [I became perplexed], and with myself to dispute Wheither I were chose or noght chose; on Holy Chirche I thoughte, That underfonged [received] me atte font for oon of Goddes chosene. ${ }^{10}$

The dreamer's decision to commit his body to the parish rather than the friary draws particular attention to the spatial specificity of both burial and baptism and to the symbolic function of the font as an emblem of parochial identity. In refusing burial at "hire hous," he chooses his own parish-"my parisshe chirche"-instead. And he does so, it seems, out of a sense of belonging; wherever a person was christened is where, "by kynde," the dreamer determines, he should be buried. His later memory of Holy Church centers not only on the parish but on one of its most striking monuments.

Late medieval laypeople understood and experienced parochial devotion in ritual and spatial terms: in the parish, at the font, even in a churchyard grave. Baptism and burial were central to lay spirituality and to the construction and representation of the parish and parochial identity. They also framed the nave of a parish church, from the font at the western end to the image of souls rising from their graves in a Last Judgment painting over the chancel arch. Throughout the fourteenth century, the rituals, objects, and spaces associated with baptism and burial appear as emblems of parochial identity in a wide variety of texts, from poetry and sermon exempla to handbooks written for priests. Beyond its role in welcoming new Christians, the baptismal font emerges as the source not only of parochial identity but of an extended sense of spiritual kinship among parishioners, both living and dead. The churchyard was just as central to lay spiritual identity and is often figured as a site for negotiating the extended spiritual community that baptism established between the living and the dead. The newly baptized parishioner entered a community that included both the living and the dead, and churchyard burial, in turn, represented a renewal of that vow, a homecoming or return to the place of one's baptism, and a lateral move into the fellowship of the dead. This chapter explores the productivity of font and churchyard, both in the parish and on the page. Given the important role they played in making and shaping the parish, their prominence in late medieval poetry and sermons, for example, should not come as a surprise. Even as the textual representation of

10. Ibid., $11.115-18$. 
font and churchyard reflects the productive role they played in late medieval culture, however, it also does productive work of its own by conjuring up the very matter of the parish.

\section{At the Font}

The life of the Christian began "atte font." Will uses this phrase to describe the location of baptism - in passus 11, he thinks of Holy Church, who "underfonged [him] atte font." But beyond its descriptive function, the phrase activates the material and liturgical contexts of baptism, calling up the parish nave and its most striking monument. ${ }^{12}$ In some parish churches, fonts were works of art, carved with images and topped with ornate wooden pinnacles that reached into the rafters. But even the most basic font was a monument to parochial membership because it was the focal point of the baptismal ceremony. Indeed, the phrase "atte font" gestures to the liturgy itself, which carefully choreographed the catechumen's movement through church space, beginning at the church door and ending at the font. For example, in the Sarum Rite, the ceremony begins with the priest calling the child "to the font of baptism." After a series of readings and prayers, the priest carries the child "into the church, having asked his (or her) name, saying: N., enter into the temple of God that thou mayest have eternal life, and live forever." At the start of the baptism proper, the child is then "carried to the font by those who are to receive him at baptism." ${ }^{13}$ Will's prepositional phrase also calls attention to the spatial fixity of baptism, which was reinforced by the font itself. The Sarum Rite stipulates not only that baptism should occur only "in churches," but that the font itself-ideally constructed of "stone whole" - should be immovable. ${ }^{14}$ And even on days when the font was not being used for baptism, it was very likely the first thing a person saw upon entering the church. ${ }^{15}$

11. Ibid., 11.118.

12. For Vitz, when liturgical quotations are used in literature, they have the potential to evoke the visual, ritual, and emotional contexts of the liturgy. "Liturgical versus Biblical Citation in Medieval Vernacular Literature," 443-49.

13. Quotations from the Sarum Rite for baptism are from Fisher's translation, offered as an appendix to Christian Initiation, 158-79 (at 164-65, 172, emphasis mine).

14. "It is not lawful to baptize someone in a hall or apartment or some other private place, but only in churches in which there are fonts specially appointed for this purpose, unless it be the child of a king or prince, or such necessity have arisen that it is not possible to come to church without risk. Moreover if possible let a presbyter have always a font of stone whole and decent for baptizing: but if he cannot, let him have a vessel suitable for baptism which may on no account be put to other uses nor taken outside the church.” Ibid., 176-77.

15. Davies observes that the font would have been "immediately visible upon entering the 
In referencing the font, Will also calls up the broader social context of baptism. Kellie Robertson's recent study of medieval objects reminds us, via Heidegger, that material things function as "assemblies" that gather people together. ${ }^{16}$ The ceremony itself drew catechumens to the font, but it also amassed a broader spiritual network around the newly baptized Christian; this is often emphasized in visual representations of baptism, which are typically packed with people, all congregating around the font. ${ }^{17}$ Godparents played a central role in assembling this community; they named the child at the church door, carried him or her to the font, and promised to teach him or her a catalogue of prayers "after the lawe of all holy churche." ${ }^{18}$ They also formed the roots of an extended spiritual family for the child: although the simple fact of baptism gave a child access to Christian salvation, the involvement of godparents had the added practical benefit of establishing a system of mutual spiritual support between godparent and godchild. But the commitment forged at the font extended far beyond a catechumen and his or her godparents. The author of Jacob's Well (c. 1375-1400), for example, articulates a complex web of "gostly kynrede" that includes not only the child and its godparents but also the spouses and children of the godparents, the parents of the baptized child, and the person administering the baptism:

Be twixen [between] pe god chyld \& godfadyr \& godmodyr is gostly kynrede. Also a twixe pe godchyld \& pe chyldryn of godfadyr \& godmodyr. Also atwixe pe godchyld \& pe husbonde of pe godmodyr zif he knewe here fleschly beforn. Also atwixen pe godchyld \& pe wyif of pe godfadyr of hym beforn fleschly knowyn. Also a twixe pe fadyr \& modyr and godfadyr and godmodyr of pe godchyld. Also atwixe pe godchyld \& hem pat baptysen pe chylde. Also atwixe pe godchylde \& pe chylderyn of hem pat baptysen. Also a twyxe pe godchyld \& pe wyif of hym pat baptyseth pe chyld. 3yf sche be of hym beforen fleschly knowyn. Also a twixe pe godchylde \& pe husbonde of here pat baptysed pat chyld zif he knewe here fleschly beforn. Also a twixe hem pat baptysen pe chyld \& fadyr and modyr of pat chyld. ${ }^{19}$

church" because it would not have been "masked by enclosing pews," which were a late fifteenthcentury invention. Architectural Setting of Baptism, 76.

16. Robertson, "Medieval Things," 1074.

17. Nichols analyzes a number of stone fonts carved with images of the seven sacraments in Seeable Signs. See especially plates 34,36 , and 37 for examples of baptismal scenes that feature crowds of people - the priest, the parents, and several godparents—at the font.

18. Fisher, Christian Initiation, 166.

19. Only the first half of Jacob's Well is available in the EETS edition. The author's treatment of baptism appears in the second half of the treatise, edited by Atchley in "The 'Wose' of 
The network of relationships established through a child's baptism precludes marriage among its members: "All pis gostly kynrede," the Well-author warns, "lettyth matrimonye to be solenyzed \& departyd hem pat ben weddyd in pis kynrede." ${ }^{20}$ But the repetition of the phrase "also a twixe" simultaneously reinforces the spiritual productivity of baptism and the robust, infinitely expanding network of relationships that it brought into being, inaugurating what John Bossy has called "a formal state of friendship between the spiritual kin and the natural kin," a voluntary "kinship-group partly natural and partly artificial." ${ }^{21}$ This special bond of kinship had the advantage of "securing mutual support in salvation" because "one's chance of eternal life, as well as one's welfare in the present, depend[ed] on the size, cohesiveness and wealth of one's kindred."22 Baptism enlarged the spiritual networks of both catechumens and godparents, bettering everyone's access to salvation.

The font was a powerful symbol of the parish community and its collective efforts toward salvation. The location of the font played an important role in this: standing at the east end of the nave, it formed an axis with the high altar that linked the death of Christ with the eternal life of the Christian. The Rite itself ends, in fact, by looking ahead to death and urging the new Christian to "guard" his or her commitment to God by returning a clean chrismal robe to him at death. ${ }^{23}$ The author of the Prick of Conscience (c. 1325-50) sharpens the connection between font and future salvation by emphasizing that the robe should be "als clene as it first was, / When he was hoven [raised] at funstane." ${ }^{24}$ In churches where the nave was flanked at one end by the font and at the other with a chancel arch painting of the Last Judgment, the connection between baptism, death, and salvation would have been even more powerful. At the font, the members of a parish made commitments to God and to one another in anticipation of rising from their graves together to face judgment. Indeed, when Will thinks of his baptism, he does so as part of an extended rumination

Jacob's Well," 315-16. I have slightly modified the passage by silently expanding the abbreviations and adding punctuation. Fitzgibbons reads Jacob's Well with an eye to parochial devotion, focusing in particular on its concern with the "process" of lay religious instruction and on its "conception of parish life [as] defined by shared intellectual engagement." "Jacob's Well and Penitential Pedagogy," 215, 220.

20. Atchley, "The 'Wose' of Jacob's Well," 316.

21. Bossy, "Blood and Baptism," 133-34. Tanner and Watson argue that "the Church as a society of the baptised brought a communal dimension to the responsibility of baptism." Tanner and Watson, "Least of the Laity: The Minimum Requirements for a Medieval Christian," 398.

22. Bossy, "Blood and Baptism," 136. Bennett discusses spiritual kinship and the transcendence of traditional social boundaries such as "age, lineage, affinity, neighborhood, occupation, [and] rank," in "Spiritual Kinship and the Baptismal Name," 125.

23. Fisher, Christian Initiation, 174.

24. Prick of Conscience, lines 3125-26. 
on both burial and salvation. The phrase "atte font" conjures up the material and liturgical contexts of baptism, but it also taps into the vast spiritual network that baptism established, a temporally complex network that included both the living and the dead. The font itself gathers this community, but it also looks ahead to another site of assembly: the grave. Will links font and grave when he ventriloquizes Conscience's claim that a person "sholde be buryed" where he was "cristned." ${ }^{25}$ If the font produced and assembled Christians, the churchyard offered opportunities, through the practices surrounding burial and the care of souls, for reaffirming and renewing these relationships.

In Handlyng Synne, Robert Mannyng explores the relationship between baptism and salvation in a story about the terrible fate of a godparent who betrays the commitment he made when he presented his goddaughter at the font. Mannyng's book, written between 1303 and 1317, ${ }^{26}$ offers commentary on a wide range of pastoral subjects, including the Ten Commandments, the Seven Deadly Sins, and the Sacraments. Although the story about the godfather appears as part of Mannyng's treatment of the sacrament of baptism, it focuses on the death of a sinner and his eventual rejection from the parish and its churchyard. The narrative begins with a godfather lifting up his goddaughter at the font on the day of her baptism but quickly zooms ahead several years. The "mayde chyld" whom the godfather "hefe [lifted] ones at pe fonte" is now on the cusp of "wommannes elde." ${ }^{27}$ Nearing the end of his Lenten fast, the man requests the company of his goddaughter on Easter Sunday, not just at Mass but "all pat yche ester day / And lenger $3 y f$ hyt were here pay." ${ }^{28}$ Thinking that "none euyl myght be done," her parents grant the request. ${ }^{29}$ But the godfather, drunk and "vnryght," rapes his goddaughter that very night. ${ }^{30}$ Seven days later, the man dies. Soon after his burial, the churchyard bursts into flames, incinerating the godfather's body until no trace of it remains:

Sone after pat he byryed was,

Veniaunce com for pat trespas.

Out of hys graue a fyre vp smote,

Ful stynkyng and ful hote,

25. Langland, Piers Plowman, 11.67.

26. Raymo, Manual of the Writings, 2256. According to Sullens, Handlyng Synne survives in nine manuscripts, all dating to c. 1400 or later. Mannyng, Handlyng Synne, xviii-xix. All quotations from Handlyng Synne have been taken from the Sullens edition.

27. Ibid., lines 9727-30.

28. Ibid., lines 9735-36.

29. Ibid., line 9738 .

30. Ibid., line 9739 . 
And brenned pat cursed body al, And stone \& erpe bope gret \& smal;

$\mathrm{Al}$ was so brend yn to pe grounde, pat of hys body myght noght be founde.

Here mowe ze here apertly why

God toke veniaunce greuusly, pat God shewed so moche hys yre, For he synned pat tyme wyp hyre, pat he lyfte of pe font stone.

Hyt ys a warnyng to vs echone pat we kepe pe sacrament, Oure bapteme pat God hap lent. ${ }^{31}$

Soon after he was buried, vengeance came for that trespass; a hot, stinking fire rose up from his grave and burned that cursed body in its entirety, even the earth and stones, both big and small. Everything burned into the ground-no part of his body could be found. Here may you openly hear why God took such grievous vengeance, and why he showed his anger so forcefully: he sinned with the one he lifted at the font stone. It is a warning to us all to keep the sacrament of baptism, given to us by God.

The punishment of the sinful godparent draws close attention to the space and fabric of the church as Mannyng explores the relationship not only between baptism and salvation but between godparents and the wider parish community. Mannyng figures baptism as a vertical pathway to heaven; the lifting of the girl at the font points to her potential for salvation as a new member of Christendom and looks ahead to her future ascension to heaven. But Mannyng also explores the opposite end of this vertical spectrum by demonstrating the dire consequences of the godfather's betrayal. While baptism produces Christians, sin can destroy them. Indeed, the protagonist lifts up his goddaughter at the font only to hurl himself down to hell by violating the terms of the sacrament.

Although Mannyng frames the story with references to the font, he stages most of the drama in and through the churchyard. In this tale of postmortem justice, the churchyard is a site of rejection and exclusion, at least for those who betray the commitments they make at the font. Mannyng's baptism story chronicles the disenfranchisement of a sinful godparent for whom the churchyard, instead of providing a long-term place where the living might pray on

31. Ibid., lines $9773-88$. 
his behalf, becomes a kind of earthly hell that destroys his body and deletes him from the extended community of the parish. The fire is so destructive that nothing of the man's corpse remains, not even a bone: his disappearance from the churchyard suggests his deletion from the book of life. ${ }^{32}$ In linking font and churchyard grave, Mannyng's story ultimately explores the churchyard as a kind of material map of the parish, a roster of those who deserve access to its long-term spiritual benefits. When Mannyng exhorts readers to "kepe pe sacrament," he asks them to think about what a sinner stands to lose by being rejected from a site that was powerfully associated with mutual help among the living and the dead. ${ }^{33}$ Baptism gave a person access to Christendom and, more particularly, to a spiritual network founded on reciprocity. These bonds were retained and even intensified through parochial churchyard burial. Clive Burgess rightly suggests that the characteristic "penitential mentality" of the later Middle Ages was "channelled through the parish," ${ }^{34}$ and I want to argue that this channeling occurred most explicitly in the parish churchyard, where intersections of individual and community, living and dead, past and present, were made manifest.

\section{Churchyard Reciprocity}

Despite Mannyng's emphasis on exclusion and rejection, the churchyard was also powerfully associated with reciprocity and solidarity among the extended generations of the parish. In a Middle English sermon for the Feast of All Souls, John Mirk offers an exemplum in which the churchyard brings together the living and the dead. He begins by describing the feast and by emphasizing the spiritual needs and demands of the dead: on the Feast of All Souls, he explains, "Holy Chyrch makyth mynde, and syngeth and reduth generalych for alle pe soules pat ben in purgatory, hauyng full beleue to releson hem of hure peyne." ${ }^{35}$ Even "pe lest preyere," he maintains, "doth hem gode." ${ }^{36}$ But this

32. This is not the only example of churchyard corpse rejection in Handlyng Synne. Readers might be reminded of the well-known story of the Dancers of Colbek, who commit sacrilege by dancing in the churchyard during the celebration of the Christmas Mass. When one of the dancers loses an arm, the priest attempts to bury the severed limb, and the earth rejects it no fewer than three times. Mannyng, Handlyng Synne, lines 9015-260. See also Miller's discussion of this story in "Displaced Souls," 610-12.

33. Mannyng, Handlyng Synne, line 9787.

34. Burgess, "Purgatory and Pious Motive," 71.

35. Mirk, Festial, 242 (lines 6-8). Written between 1385 and 1390, Mirk's sermon collection survives in forty-three manuscripts and several printed editions. Powell, "Festial: The Priest and His Parish," 160-61.

36. Mirk, Festial, 242 (line 11). 
reciprocity was mutual, and Mirk tells the story of a man who prays for the dead and receives their help in return:

per was a man pat hadde hys hous be pe chyrch-3orde so pat pe dore oponyd towarde pe chyrch. Pan hadde he a maner pat, as ofton os he com or zode oure pe chyrch-zorde, he wolde seyn De profundis for alle criston soules. Pan it happonid so pat on a day he was pursuod wyth enmyes pat he flow homwarde. Bot whan he com into pe chyrch-3orde he powth: "Now is tyme to say De profundis," and knelud adoune and sayde it. And anone perwyth alle pis chyrch-zorde rose ful of bodyes, vchone wyth an instrument in hys hond of hys crafte, and dryuon azeyne hys enmyes. And whan pei sene pat, pei cryed God mercy, and pis mon, and he was eure aftur be more devoute preying for soules. ${ }^{37}$

There once was a man who had a house next to the churchyard, its door opening toward the church. Whenever he went through the churchyard, he had a habit of saying the De profundis for all Christian souls. Then one day, he rushed home, pursued by enemies. When he came into the churchyard, however, he thought, "now it is time to say the De profundis," and he kneeled down and said it. Immediately the churchyard was full of risen bodies, each holding a tool of his trade, and each driving against his enemies. When they saw this, they all asked God for mercy, including the man who had been pursued, and he was ever after more devout in praying for the souls of the dead.

Mirk's All Souls story explores the sense of spiritual reciprocity that increasingly defined the relationship between the living and the dead in the medieval parish. Prayers for the dead were beneficial to those languishing in Purgatory, but they also helped the living: when pursued by enemies, Mirk's devout layman is rescued by the risen dead, each of whom carries an "ynstrument" of the "crafte" he practiced during life. The layman's prayers also have a positive effect on the unnamed enemies who, in an important addition to Voragine's barebones account in the Golden Legend, undergo a kind of spiritual conversion when they witness the rising of the grateful dead and beg God for Mercy. ${ }^{38}$

Beyond teaching listeners about the efficacy of praying for the dead, Mirk draws special attention to the role of the churchyard. An earlier version of the

37. Ibid., 242 (lines 22-32).

38. Ibid., 242 (line 32 ). 
story appears in the Golden Legend, where it provides a more straightforward illustration of the benefits of prayer:

Another example, this one from the Cantor of Paris, shows how grateful the dead are for the prayers of the living. There was a man who, as he walked through the cemetery, always recited the De profundis for the dead. Once, when he was running away through the cemetery with his enemies after him, the buried, each one armed with the tool proper to his craft, quickly rose and defended the fleeing man with might and main. His pursuers, terrified, retreated in haste. ${ }^{39}$

In adapting the story, Mirk foregrounds the role of the "chyrch-3orde," a term he repeats four times in the brief narrative. Although Mirk follows the Golden Legend in confirming that the prayers of the living are "pleasing" to the dead, his story focuses on the churchyard as the place where this reciprocal relationship is negotiated. In addition to its association with purgatorial obligation, Mirk's churchyard is a place where Purgatory meets parish, where the living and the dead come together as an extended parochial community.

As many scholars have observed, the "bookkeeping logic" associated with Purgatory forged a temporal link between the living and the dead: suffrages made by the living on behalf of the dead were indirectly proportional to the duration of a soul's residence in Purgatory. ${ }^{40}$ In other words, earthly time expended in the form of a commemorative prayer functioned as a time-saving voucher that could be directly applied to a dead person's term of penance. But the churchyard also offered a spatial link between the living and the dead. In Mirk's story, for example, the world of the dead is comfortingly close at hand. The nearness of Purgatory is often represented in the context of the church; in some books of hours, for example, the illuminated miniatures that accompany the Office of the Dead call even more attention to the proximity of Purgatory by depicting it directly beneath the church. In an image of a funeral Mass from a fifteenth-century book of hours (fig. 1), Purgatory and its smoldering inhabitants are portrayed in a subterranean crypt directly beneath the tiled floor of a church where a funeral mass is being celebrated. ${ }^{41}$ Purgatory is archi-

39. "Quam gratae etiam sint defunctis orationes vivorum, patet ex hoc, quoniam quidam, ut refert cantor Parisiensis, dum per cimiterium transiret, semper psalmum de defunctis dicebat pro defunctis. Qui cum ab inimicis per cimiterium fugiens insequeretur, continuo mortui surrexerunt et unusquisque instrumentum sui officii in manu habebat et sic ipsum viriliter defenderunt et inimicos territos fugaverunt." Voragine, Legenda Aurea, 733. The English translation is from Voragine, Golden Legend, 2:285.

40. Le Goff, Birth of Purgatory, 227.

41. For a discussion of this manuscript, see Randall, Medieval and Renaissance Manuscripts 


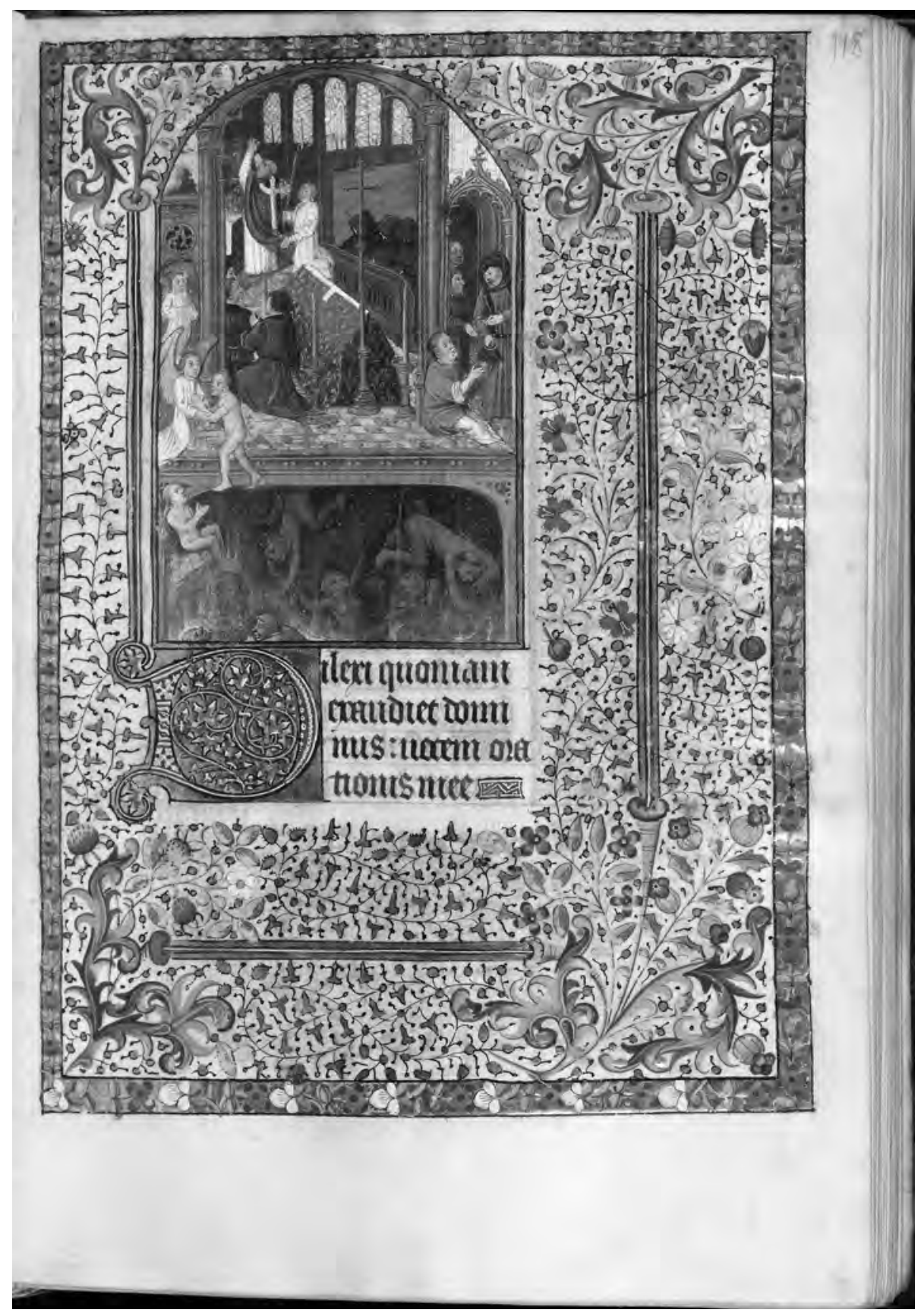

Figure 1. Mass helps souls in Purgatory. Baltimore, Walters Art Gallery, MS W.274 (c. 1460-70), fol.118r. 
tecturally distinct from the church, separated by the tiled floor and by a thick wooden frame that cuts across the image, dividing it into upper and lower halves. The image does more than show the efficacy of the Mass: beyond its proximity to the altar, Purgatory also borders on the world outside the chancel, where a layman gives alms to the poor. As he dips his hand down into his purse, two naked souls rise up and out of the flames toward a pair of angels. Purgatory is thus part of a complex spiritual landscape that encompasses liturgical time, eschatological time, and everyday life in the present. But as Mirk's All Souls exemplum suggests, the proximity of the dead is also powerfully expressed in the churchyard, a place where past, present, and future collide, a place where the dead rise from their graves to walk among the living. The author of the Prick of Conscience explores the figurative nearness of Purgatory in more explicitly topographical terms, locating it just beneath the surface of the earth. ${ }^{42}$ The dead were, in fact, just outside, under the grass. In a number of Last Judgment paintings, the dead rise from outdoor graves that strongly evoke the churchyard. In the well-known doom paintings at Salisbury and Coventry, for example, artists have taken great pains to reinforce the outdoor setting by strewing the scene with rocks and tufts of grass, the visual equivalent, perhaps, of Mirk's repetition of "chyrch-3orde" in his All Souls tale. ${ }^{43}$

\section{Sharing the Churchyard}

The late medieval churchyard was associated not only with intergenerational reciprocity but also with sharing, and, for this reason, it was also subject to certain behavioral expectations. In Handlyng Synne, Robert Mannyng treats the subject in a section devoted to sacrilege in which he chastises those who abuse the space by acting out of self-interest:

Vnkynd man ys he hardyly

pat yn cherche zerd dop vyleyny.

in the Walters Art Gallery, 2:157-66. See also the comparison of purgatorial reciprocity to the mechanism of a well in an image from a fifteenth-century Carthusian miscellany, which I discuss in chapter 5 (fig. 7 ).

42. "Pe stede pat purgatory es calde, / Under pe erthe es, als I halde, / Aboven pe stede, als som clerkes telles, / Par vncrysomd + childer duells" (Prick of Conscience, lines 2788-91) [The place called Purgatory is under the earth, as I understand, above the place, as some clerks say, where unbaptized children dwell].

43. Photographs of the mural at Coventry are available at http://paintedchurch.org/coveht .htm. For a more general discussion of Last Judgment murals, including a photograph of the Salisbury Doom, see Benson, Public "Piers Plowman," 172-81 and fig. 2. See also Caiger-Smith, English Medieval Mural Paintings, 31-43; Rosewell, Medieval Wall Paintings, 72-81. 
Oure long hous hyt ys to come

To rest yn tyl pe day of dome.

parfore we shuld, 3yf we were kynde,

Kepe hyt clene with gode mynde.

And pese prestes me pynkp do synne

Pat late here bestes fyle per ynne.

pe gres ys hys pat pere grenes,

pe place ys pe parysshenes. ${ }^{44}$

The man who acts villainously in the churchyard is audaciously unkind; it is the longhouse that we rest in until doomsday. Therefore we should, if we were kynde, have the good sense to keep it clean. I think these priests sin when they allow their animals to defile it. The grass belongs to him who greens it; the place is the parishioners'.

Mannyng reinforces the shared nature of the churchyard by studding the passage with first-person pronouns and by describing it as "oure long hous," a place of collective rest until doom. ${ }^{45}$ In doing so, he makes an important departure from his Anglo-Norman source text, ${ }^{46}$ which describes the "cemetery" (cymiter) more simply as "our house" (nostre mesun). ${ }^{47}$ Mannyng's addition amplifies the temporal dimensions of the churchyard as a long-term resting place that fills the expanse of time between death and the Last Judgment. It also evokes a powerful sense of horizontality-the body laid from west to east in the grave. In imagining the grave as a longhouse, Mannyng perhaps borrows from parochial Last Judgment iconography. Like those resurrected bodies dragging themselves up and out of a landscape of opened graves, the residents of Mannyng's longhouse wait there "tyle pe day of dome." The horizontality of the longhouse stands in sharp contrast with the verticality that is to come: upright, resurrected bodies abandon their churchyard graves in order to ascend to heaven alongside their fellow parishioners. Indeed, Mirk describes the laying out of a corpse as advanced preparation for bodily resur-

44. Mannyng, Handlyng Synne, lines 8655-64.

45. Ibid., line 8657 .

46. As Mannyng explains in his prologue, he "tournede" the "manuel de pecchees" into "englyssh tonge out of frankys." Handlyng Synne, 77-82. Furnivall presents excerpts from William of Waddington's Anglo-Norman Manuel de Péchés (c. 1260) in his parallel text edition of Handlyng Synne. Schemmann has warned that Furnivall's edition, currently the only one available, is unreliable: Confessional Literature and Lay Education, 4-5. For further discussion of the Manuel des Péchés, see especially Sullivan, "Brief Textual History of the Manuel des Péchés," 337-46; idem, "Author of the Manuel des Péchés," 155-57.

47. "Cymiter est nostre mesun / Ou nus tresuz reposerum / E le iugement atendrum; / Pus, net garder le deuum." Waddington, Manuel des Péchés (in Mannyng, Handlyng Synne, ed. Furnivall), 273 (lines 6697-704). 
rection. As he writes in his burial day sermon, the body of a dead person is oriented eastward "to ben pe more redy to sene Criste pat comyth oute of pe est to pe dome, and so ryson azeynus [facing] hym." 48 "Longhouse" is, moreover, an agricultural term generally used to describe one-story buildings that provide general storage space and shelter for farm animals. ${ }^{49}$ In Mannyng's description of churchyard burial, the parochial longhouse ultimately retains its agricultural significance as the site of the Last Judgment harvest, where Christians will be reaped and collected by God..$^{\circ}$

Mannyng's description of the churchyard as a shared longhouse points toward the sense of parochial solidarity that was deeply associated with churchyard burial practices. Burial rights were central to the identity and autonomy of the parish, and parishioners petitioned for them when necessary. ${ }^{51}$ A church's possession of a cemetery meant not only that its parishioners would have access to all of the sacraments in a single location but that the extended parish community would be kept intact, even in death. According to canon law, any church that had a churchyard was required to offer free burial to its parishioners, although there were often fees owed to gravediggers and other personnel. ${ }^{52}$ Those looking to make more of an individual statement might seek burial inside the church; some commissioned carvings in brass and stone, while others paid for elaborate effigies along aisles, under arches, or nestled against altars or shrines. ${ }^{53}$ The vast majority of laypeople, however, would have been buried outside in their parish churchyards.

48. Mirk, Festial, 257 (lines 28-29).

49. According to Grenville, a medieval reference to a "longhouse" or domus longa generally refers to "a long building, usually separate from the main dwelling, with an agricultural purpose." Medieval Housing, 137. Mercer tentatively defines the medieval longhouse as a type of farm building "which might house animals, which might be attached to a dwelling, but which was thought of as one whose functions were distinct from that of the dwelling." "Domus Longa," 9. Neither Mercer nor Grenville notes late medieval literary deployments of the term.

50. Handlyng Synne marks one of the term's earliest uses as a way of describing burial. See the $M E D$ entry for "hom," n., 2c: "long , a final resting place, the grave."

51. In the case of semi-independent chapels, for example, securing burial rights was a stepping stone to achieving full parochial status. On the evidence from Bath and Wells, see French, People of the Parish, 24-25; on London, see Harding, Dead and the Living, 38.

52. Ibid., 55-56; Dinn, "Burial Patterns, Social Status and Gender," 241. Fixed fees were generally paid to gravediggers. Harding, "Burial Choice and Burial Location," 125-26.

53. Rogers explores "the positioning of monuments" as "a reflection of the devotional priorities and the social networks of the living" in "Location of Monuments in Late Medieval Parish Churches," 276. Canon law stipulated that only benefactors and members of the clergy could be buried inside the church itself, but this restriction became increasingly relaxed in practice; by 1500, paying for indoor church burial was a "standard practice" among laypeople of means in London. Harding, "Burial Choice and Burial Location," 30. Harding warns, however, that even though burial inside the church was "always a minority option," the "social bias of willmaking makes it appear more important in statistical terms than it really was." Dead and the Living, 132. And as Rogers reminds us, "testators did not always get what they asked for." "Location of Monuments," 262. 
Churchyard burial practices reinforced the shared nature of the space. For example, many parishes provided a communal parish coffin or "common box" used and reused for transport to and from the churchyard..$^{54}$ Long-term grave markers seem not to have been a standard feature of late medieval burial practice..$^{55}$ If anything, a churchyard grave may have been marked with a wooden cross. In Middle English sermons, this kind of humble churchyard burial symbolizes membership in the greater community of the saved. In the Speculum Sacerdotale (c. 1425), for example, a cross is staked at the head of a person's grave "in tokenynge that he is a Cristen man." ${ }^{56}$ For Mirk, a person is buried with a "cros of tre sette at hys hed, schewing pat he hath ful beleue to ben sauid be Crystus passion pat dyud for hym on pe cros of tre." 57 Although testamentary evidence demonstrates parishioners' concern with expressing individual loyalties through personal bequests and monetary donations, churchyard burial constituted a more generic and collective memorial; in the absence of more permanent markers, churchyard graves would not have been recognizable over long periods of time, their inhabitants a collection of unidentifiable skeletons.

This sense of anonymity was reinforced through the use of on-site storage for dry bones. To free up space in heavily used burial grounds, bones were exhumed and collected either in crypts underneath the church or in freestanding charnel houses outside in the churchyard.$^{58}$ From communal parish coffin to charnel house bone pile, churchyard burial deindividualized the dead while also celebrating their ongoing membership in the parish. Churchyard charnels served an important space-saving function, but they were also impressive monuments in their own right. Even so, few outlasted the Reformation. ${ }^{59}$ The charnel nestled against the churchyard wall of St. Michael's

54. Cox, Parish Registers of England, 21; Daniell, Death and Burial in Medieval England, 58; Gittings, Death, Burial, and the Individual, 61. Harding reports that "many burials in church up to the mid-sixteenth century were not coffined, and nor were most churchyard burials for another half-century at least." In London churchyards, moreover, references to coffined burial are "unusual" before the late sixteenth century. Dead and the Living, 59; and see 141-45 for further discussion of coffin usage.

55. Daniell, Death and Burial, 108; Dinn, “Burial Patterns, Social Status and Gender, 246. Harding, Dead and the Living, 62.

56. Speculum Sacerdotale, 230 (lines 7-8).

57. Mirk, Festial, 257 (lines 29-31). On shrouding more generally, see Daniell, Death and Burial, 43.

58. Harding speculates that, unlike Parisian charnels, which were "systematically managed," "it seems probable that London parish charnels were the product of a more casual process in which the sexton collected bones disturbed by later burials and stored them appropriately." Dead and the Living, 64. For further discussion of English charnel practices, see Bond, Introduction to English Church Architecture, 2:84-88; Cook, English Mediaeval Parish Church, 124-30.

59. Harding, Dead and the Living, 64; Houlbrooke, Death, Religion, and the Family, 333. 
in Mere (Wiltshire) is a rare exception. ${ }^{60}$ At St. Mary's in Mildenhall (Suffolk), only the ivy-covered ruins remain. ${ }^{61}$ Because parish charnels have never been studied in any sustained or systematic way, their use and management remains unclear. ${ }^{62}$ At Exeter and Norwich, charnels were staffed by chaplains who spent their days singing Masses for the dead. ${ }^{63}$ And evidence from extant indoor crypts offers a window onto the care with which a charnel's bones may have been stored and even artfully displayed. ${ }^{64}$ In the average parish churchyard, then, very plain and with few if any permanent grave markers, a charnel house gave the dead an impressive visual and ritual presence, insuring that the living members of the parish were in constant contact with generations of dead parishioners.

Keeping bones on-site enabled the churchyard to unite the extended family of the parish. With this in mind, we might think once again about Mannyng's baptism exemplum. In a chilling reminder about the spiritual and social import of the churchyard, the man's corpse disappears when a fire erupts from his grave and burns everything to the ground. Mannyng tells the story, he explains, as a "warnyng" about keeping commitments made at the font. ${ }^{65}$ But if the churchyard united the extended generations of the dead, the fact that no trace of the man's body can be found, not even a bone for the charnel, also points to the absolute nature of his exclusion: with no physical presence in the churchyard, he has no purchase on the spiritual network that churchyard burial facilitated. The social and spiritual benefits that he loses

Cook discusses the rediscovery of several charnel crypts during post-WWII reconstruction in London in his English Mediaeval Parish Church, 129-30.

6o. Friar has suggested that the Mere charnel, "erected against the churchyard wall," is typical among "churchyard ossuaries." Companion to the English Parish Church, 327.

61. In a brief entry for Mildenhall, Pevsner reports "the remains of a charnel house with a chapel of St. Michael over." Suffolk, 365. Mortlock adds that the charnel was "founded in 1387 by Ralph de Walsham" and that it was "endowed with a priest to say masses for the dead." Guide to Suffolk Churches, 343 .

62. Churchyard charnels are typically only briefly mentioned in area guides and architectural surveys. Bond includes a list of nearly two dozen surviving "bone houses," but he does not differentiate between church crypts and free-standing churchyard charnels. Introduction to English Church Architecture, 86-88.

63. On the evidence from Exeter and Norwich, see Orme, "Charnel Chapel of Exeter Cathedral, 162; Houlbrooke, Death, Religion, and the Family, 332-33; Gilchrist, Norwich Cathedral Close, 34 .

64. Friar includes an image of skulls shelved at the ossuary of St. Leonard's, Hythe (Kent). Companion to the English Parish Church, 327. See also Roberts, "Femora from a Medieval Charnel House," 120 (plate 1). In some striking Continental examples, bones were displayed in underground catacombs or used for decorative purposes inside churches. Ragon, Space of Death, 51-52.

65. Mannyng, Handlyng Synne, line 9786. 
are powerfully expressed in an image from an early fifteenth-century French book of hours (fig. 2). ${ }^{66}$ This churchyard scene appears at the beginning of the Office of the Dead and emphasizes the communal and ceremonial aspects of burial: clerics enter the churchyard with a cross, a bell, a bucket of holy water, and a liturgical book. In the foreground of the image, a priest leads a procession from the church into the churchyard as two men lower a shrouded body into a freshly dug grave. The man who stands at the center is probably a representative of the deceased person's fraternity or parish guild. ${ }^{67}$ Further in the background, three wooden grave markers stick up out of the ground, and a cloistered walkway along the back wall doubles as a display case for bones, with rows of skulls peering out from a lofted arcade. ${ }^{68}$ The churchyard in this image is actively shared by the living, the newly dead, and the long dead; in a single patch of ground, the extended age-groups of the parish are brought together as a unified spiritual community. ${ }^{69}$

But churchyards could also be caught up in conflict and disorder. Indeed, when English bishops made formal visitations to the parishes in their dioceses, they found churchyards marred by broken gates and crumbling walls, defiled by farm animals, and incurred upon by greedy, land-filching neighbors. $^{70}$ In chronicling churchyard abuse, however, visitation records evince the ideal churchyard, revealing clear expectations about mindful conduct in a shared space. In 1408, a Salisbury chaplain was cited for, among other things, his selfish misuse of the churchyard:

66. According to Wieck, the so-called Master of Morgan 453 was a Flemish artist who was active in Paris in the 1420s. Painted Prayers, 56. On the representation of death and burial in books of hours, see especially Wieck, "Death Desired," 431-76; Fiero, "Death Ritual," 271-94; Binski, Medieval Death, 53-54; Kinch, "Affirmative Negation," 15-27.

67. Wieck, Painted Prayers, 131.

68. See also Baltimore, Walters Art Gallery MS W.197, f.175V., reproduced in Wieck, "Death Desired," 473 (fig. 25). Like the churchyard pictured here, the famous Cemetery of the Innocents in Paris was surrounded by cloistered arcades in which skulls and bones were stored. See Harding, Dead and the Living, 101-13. Its walls were painted with a danse macabre scene which inspired the fifteenth-century Dance of Death murals at St. Paul's in London. Ibid., 102-3; see also Gertsman, Dance of Death.

69. Natalie Zemon Davis (citing Varagnac) describes the dead as an "age group" in "Some Tasks and Themes in the Study of Popular Religion," 327.

70. In Salisbury, for example, two members of the same parish were accused of encroachment in 1405. John Dauntesey "built a house taking in along it a foot of the graveyard," and William Wyly "made a hedge round his house taking in along it 4 feet of the graveyard." Register of John Chandler, 27. Harding explores the many uses of London churchyards in Dead and the Living, 52-55. Unlike jurisdiction over the chancel and nave, which was clearly divided among clergy and parishioners and reinforced in Episcopal statutes, churchyard regulation was a much more complicated matter, and visitation records from the period regularly record struggles between priests and parishioners over its maintenance. French, People of the Parish, 154-62. 


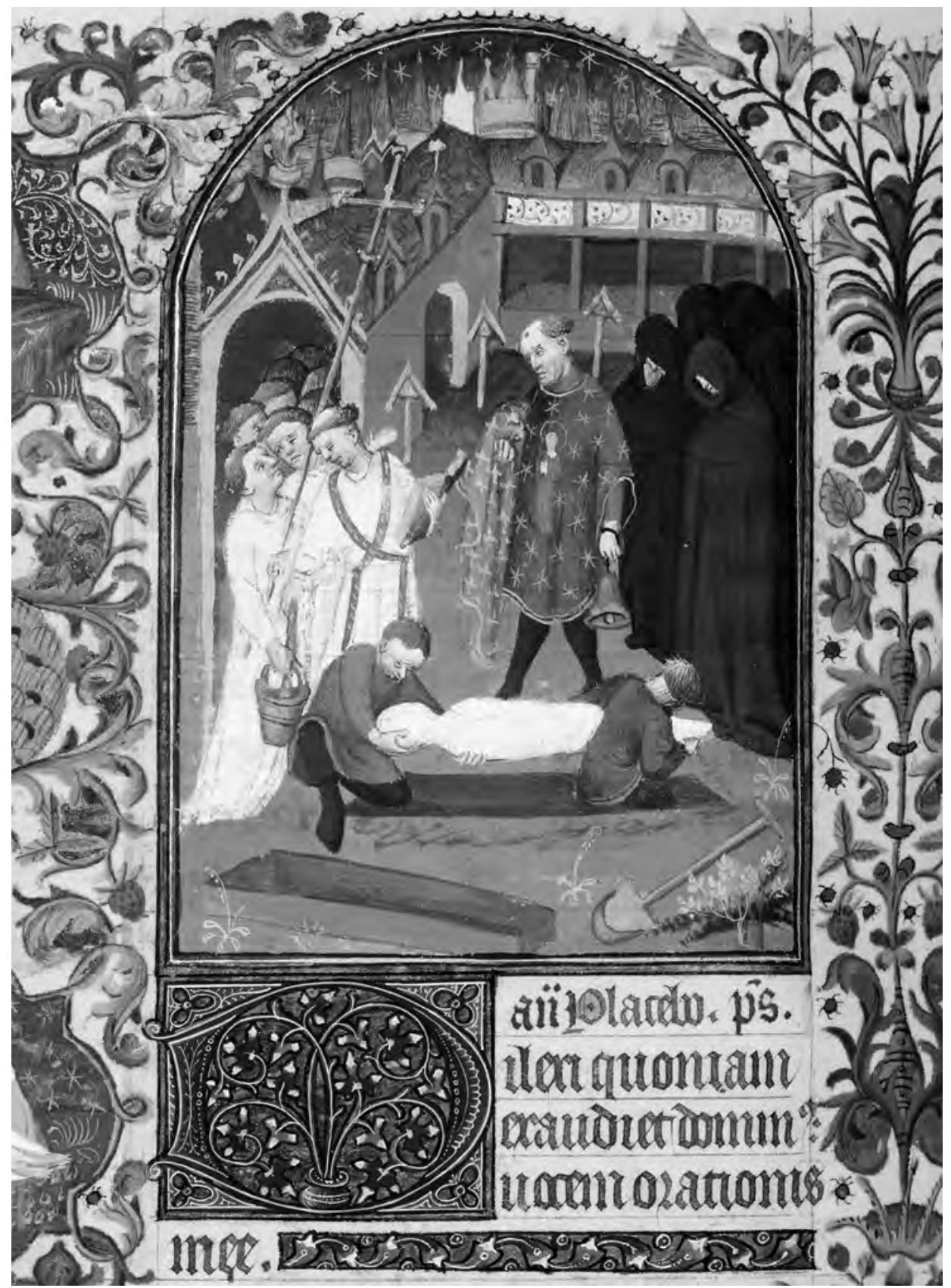

Figure 2. Churchyard burial scene. New York, Pierpont Morgan Library, MS M.453 (c. 1420-30), fol. 133v. 
Richard Bromhulle commits adultery again with Edith Godesgrome; he habitually disturbs the peace between his parishioners; he beats a pathway over graves; he tethered his horse to the churchyard gate-post, and it broke the gate-post and fouls the churchyard disgracefully; he keeps wills and compels executors to pay before returning them. Denied charges on 26 Nov. ${ }^{71}$

I have singled out this particular citation not only because of its attention to churchyard jurisdiction but because it presents the churchyard itself as a victim of insidious abuse. In addition to exploiting his parishioners both sexually and financially, Richard Bromhulle tramples his own shortcut through the graves, behaving no better than his horse. The charge represents Bromhulle as a repeat offender who puts his own interests first, but it also sheds light on certain expectations about churchyard propriety; the problem is not just that Bromhulle uses the space for grazing, or that he tramples the grass, but that he behaves like an animal in a space that was shared by both the living and the dead.

We might remember that Robert Mannyng lodges a complaint against churchyard tramplers such as Bromhulle. But instead of comparing them to horses, he calls them unkynde. Kynde has an exceptionally broad range of meanings in the Middle English: nature and natural reason; kinship and humankind; even kindness, morality, and generosity. ${ }^{72}$ Mannyng exploits this valence of possibilities in his discussion of the shared "long hous," calling on the term's association with nature and kinship as well as graciousness and reciprocity when he claims that "we shuld, 3yf we were kynde, / kepe [the churchyard] clene." ${ }^{\prime 3}$ As a space shared by the living and the dead, the churchyard represents the extended generations of the parish; its users are spiritual kin, and their conduct should reflect that affinity. Indeed, Mannyng's notion of kynde accounts for churchyard reciprocity and articulates a scale of decorum: while the "unkynde" person commits "vyleyny," those who are "kynde" work more mindfully to maintain the churchyard out of a sense of mutual respect and propriety. ${ }^{74}$ Bromhulle would, of course, stand at the lowest, most selfish, and most "unkynde" end of the spectrum.

71. Register of John Chandler, 74 .

72. See $M E D$, "kinde," both adjective and noun forms. Galloway explores the social and ethical systems that inform kynde in "Making of a Social Ethic," $365-83$. See also the entry for "kind" in Lewis, Studies in Words, 26-33.

73. Mannyng, Handlyng Synne, lines 8657, 8659-60.

74. Harding explores the relationship between medieval property ownership and its effect on an individual's conception and experience of a space in "Space, Property and Propriety," 569. 


\section{Burial "by kynde"}

A similar understanding of kynde also informs Will's decision about burial location in passus 11 of Piers Plowman. Although the important and wideranging concept of kynde has received considerable attention from scholars, ${ }^{75}$ its distinctly parochial resonances have gone unnoticed. As we have seen, when Will decides to have his body buried in a parish rather than a friary, he makes the decision according to kynde. The dreamer's preference for his own parish rather than "hire hous" brings to mind Mannyng's discussion of churchyard propriety. ${ }^{76}$ But for Will, baptism is what makes the parish his parish. Baptism welcomed new Christians into the church, giving them access to salvation while also positioning them in a reciprocal spiritual network that included both the living and the dead. In Will's formulation, "my parisshe chirche" constitutes a spiritual family, formed at the baptismal font and renewed in the grave. ${ }^{77}$ His decision accords with kynde because it acknowledges this sense of parochial kinship and secures his long-term membership in the community of the parish. Will's expression of parochial allegiance also demonstrates the relationship between parochial identity and space. I began this chapter by looking at Will's failure to recognize Holy Church-a failure that raises important questions about parochial identity and about the predication of that identity on the very space and fabric of the parish church. One reason that Holy Church may be unintelligible to Will is because she lacks the features that made the church visible to a layperson-the features through which a layperson experienced religion. In passus 11, Will conceptualizes the church in distinctly material and spatial terms, both at the font and in the grave.

When Langland gestures to particular objects, he conjures up the spatial, liturgical, and social contexts of the parish. The phrase "atte font," for example, calls up not only the liturgy of baptism but also the extended spiri-

75. On the "extreme polysemy" of kynde and its centrality to Piers Plowman, see White, Nature and Salvation, 1. Karnes considers kynde in relation to natural knowledge and experience in Imagination, Meditation, and Cognition, 179-206. Zeeman has argued that kynde should be "understood as a site of lack." "Condition of Kynde," 1-30. Returning to kynde as part of a discussion of the poem's recurring cycles of denial and desire, Zeeman argues that "suffering" is "an essential component of the kynde experience" in "Piers Plowman" and the Medieval Discourse of Desire, 206. For a discussion of kynde in the context of conversion and universal salvation, see Davis, "Spiritual Charity and the Logic of Conversion in Piers Plowman," 68-71. Langland's exploration of kynde in relation to knowledge and learning has also generated considerable interest. Mary Clemente Davlin, "Kynde Knowyng," 1-19; Morgan, "Meaning of Kind Wit," 63-74; Harwood, "Langland's Kynde Wit," 330-36.

76. Langland, Piers Plowman, 11.65.

77. Ibid. 
tual network that the ceremony established as well as the east-west axis that the font formed with the high altar. ${ }^{78}$ The poem's earliest readers continued to grapple with Langland's exploration of parochial identity in passus 11, particularly its association with space and practice. A spurious scribal addition to the B-text registers a certain ambivalence about the relationship between baptism and burial and about the suggestion that a person should, "by kynde," be buried wherever he was baptized. The line, which appears in all copies of the B-text, comes immediately after Will's memory of what Conscience told him about burial location. I include it here in italics along with the passage that it works to clarify:

For I herde onys how Conscience it tolde

pat pere a man were crystened by kynde he shulde be buryed.

Or where he were parisshene rizt pere he shulde be grauen. ${ }^{79}$

Kane and Donaldson have called the line an instance of scribal participation in "criticism of the clergy" ${ }^{\circ}$ As Wendy Scase points out, however, the practice of repaying one's baptism with parochial burial is "favourable to the parish clergy" ${ }^{\prime 1}$ Indeed, the added line confines baptism and burial to the jurisdiction of parish priests. It also reinforces the spatial fixedness of parochial identity; the "or" perhaps reads as "that is to say," or "in other words," and the line it introduces underscores the idea that burial is only "kynde" if it happens "rizt pere" in one's parish. In one copy of the poem, a fifteenthcentury reader bolsters this interpretation with a marginal gloss in abbreviated Latin: "ubi" baptized, it reads, "ibi" buried, the Latin where and there reinforcing once again the link between the fixed spaces of devotion and the communal ritual practices that took place within them..$^{82}$ A person's parochial allegiance- "where he were parisshene" - is ultimately defined by his or her

78. Ibid., 11.118 .

79. Langland, Vision of William Concerning Piers the Plowman, ed. Skeat, B. 11:65-67, emphasis mine.

80. Langland, Piers Plowman: The B Version, ed. Kane and Donaldson, 193; Langland, Piers Plowman: A Parallel-Text Edition of the A, B, C and Z Versions, ed. Schmidt, 2:398.

81. Scase speculates that these lines were omitted from the C-text in order to advance "an anticlerical viewpoint." "Piers Plowman" and the New Anticlericalism, 34.

82. "vbi baptiza' / ibi sepelir' d." London, British Library, MS Additional 35287, f. 48v. Benson and Blanchfield offer a description of the manuscript and an expanded transcription of the Latin gloss ("quia vbi baptizatur ibi sepeliri debet") in Manuscripts of "Piers Plowman," $64-67,178$. The manuscript has been dated to the early fifteenth century in Langland, ParallelText Edition, ed. Schmidt, 1:5. This copy of the poem is part of a small group of manuscripts that are "only two generations of copying removed from the archetype." Warner, Lost History of "Piers Plowman", 5. 
place of baptism, and this same place is where an individual "shulde" seek burial. ${ }^{83}$ These readings attend to the idea that, in choosing parochial burial, Will reaffirms his membership in the parish community and lays claim to the powerful network of spiritual reciprocity that parochial membership offered.

But if authors such as Langland were exploring the relationship between baptism, burial, and the community of the parish, they were also grappling with the relationship between the ideal and reality. Robert Mannyng, for example, idealizes the churchyard even as he acknowledges the acts of "vyleyny" that take place within it, and in Piers Plowman, parochial burial stands at the center of a conflict between the ideal of parochial reciprocity and the financial motivations of the friars. There is also, of course, the problem of mobility: medieval people were on the move, living and dying away from their hometowns and in parishes other than the ones in which they were baptized. Indeed, wandering itself is central to Piers Plowman, whose unfixed protagonist is walking "wide in this world" when we meet him in the prologue. ${ }^{84}$ The spurious line in passus 11 may illuminate some of these concerns, offering a different take on Will's understanding of burial according to kynde. Instead of suggesting that a person should be buried where he was baptizedthat is, where he has been a parishioner since childhood-the line may present an altogether different option: a person should be buried either where he was christened or where he is currently a parishioner. ${ }^{85}$ If a person cannot be buried where he was baptized-if that ideal cannot be achieved because, for example, a person has moved to the city to find work - then Langland may be suggesting a reasonable alternative: get buried at the very least where you now attend Mass and make your obligatory annual confession. At least one early reader of the poem registered disapproval at the prospect of burial in a parish that was not also one's place of baptism. In Corpus Christi 201, a copy of the B-text from c. 1400, the scribe has added a phrase that discourages burial outside of one's baptismal church:

Ffor y herde onys how co'science it tolde

pt per a man wer' c'stnyd per sholde he be beryed

Wher' he p'shene or noon 3 it sholde he per be g'vyd. ${ }^{86}$

83. Langland, Vision of William, ed. Skeat, B.11.67.

84. Langland, Piers Plowman, Prol. line 4.

85. As Schmidt puts it, the line "underscore[s] the axiom attributed to Conscience by extending it to cover a man's whole life or the part of it spent in the parish he may have moved to." Langland, Parallel-Text Edition, ed. Schmidt, 2:398.

86. Oxford, Corpus Christi College, MS 201, f.41.r. My transcription and emphasis. Schmidt has most recently given this manuscript a date of 1400. Langland, Parallel-Text Edition, ed. Schmidt, 1:5. Kane and Donaldson date the manuscript to the first half of the fifteenth century 
A person should be buried wherever he was christened, whether he is currently a parishioner there or not.

Any number of circumstances could take people away from their baptismal parish - a move or a marriage, for instance, or the lure of voluntary associations such as religious fraternities and guilds. Even those who chose an unmarked parish grave might also fund a more elaborate form of commemoration elsewhere. The ideal parish-one in which the living and the dead mutually benefit each other in perpetuity, in which children experience the same spiritual cycle from font to grave to charnel as their parents and grandparents - had serious staying power, but the ambivalence of Langland's early readers about the relationship between baptism and burial also suggests that ideas about the parish and parochial identity were evolving. In exploring the space and fabric of the medieval parish, fourteenth-century authors demonstrate that parochial identity is something that is actively made over the course of a lifetime and in a number of different ways. Churchyard burial at one's place of baptism is just one way to knit oneself into the fabric of the parish. Its members are also those who make sure the font is covered and those who serve as godparents, even at fonts where they themselves were not baptized. They are also those who say the De profundis when walking through a parish churchyard, even a churchyard that does not contain the bodies of their parents or grandparents. Langland's reasonable alternative to the parochial ideal-that is, his suggestion that Christians should, at the very least, be buried where they are currently parishioners-acknowledges that church is something one does, that a parish is something that its members produce. Baptism marks one's initiation into the Christian community, but parochial membership must be made, remade, and renewed on a regular basis through active involvement in a parish of some kind, alongside one's even-Cristenold and new, living and dead.

in Langland, The B Version, 8. For further discussion, see Benson and Blanchfield, Manuscripts of "Piers Plowman," 98-101. 


\section{2}

\section{Parochial Penance and the Making of the Parish}

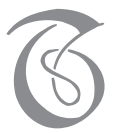

he sacrament of penance-confession and contrition, followed by satisfaction-gave late medieval laypeople a chance to renew their commitment to the church, a chance to renew the spiritual contact they had made with God at the baptismal font. Confession offered individual reconciliation with God but was also a fundamentally social and parochial enterprise. As the author of the Prick of Conscience explains it, a sin performed or "wroght" in the earth cannot pass from the earth unpunished." For this reason, sin must be reconciled, "Outher upon erthe or within / Pat es outher here par we duelle / Or in purgatory or in helle." Because sin is earthly, it must be punished either "within" the earth or "upon" it-that is, in Purgatory, hell, or here on earth where we dwell in this life. Beyond alluding to the temporal and geographical logistics of penance, the Prick-author explicitly describes it as a collective endeavor-something "we" do, whether here in this life or in Purgatory after death.

1. "Pe syn pat es in erthe wroght / Fra erthe unpunyst passes noght." Prick of Conscience, lines 2862-63.

2. Ibid., lines $2865-67$. 
Although discussions of late medieval devotion and lay community tend to take the celebration of the Eucharist as their focus, confession, too, was a collective enterprise. And it was much more central to parochial devotion than scholars have tended to assume. Indeed, it happened throughout the year: in addition to making an annual individual confession before their parish priest, a practice mandated by the Fourth Lateran Council of 1215, English laypeople were also confessing alongside their fellow parishioners every time they went to Mass. An opening prayer called the Confiteor-or, "I confess"- not only reinforced the distinctly collective and parochial contexts of penance but also framed the Mass in penitential terms. The efficacy of penance was also taught throughout the liturgical year during the quarterly celebration of the General Sentence, when the priest performed a dramatic reading of excommunicable sins before reminding listeners to amend their ways. Although many have observed, following Foucault, that confession constituted the individual subject, I argue that it also shaped the parish community. ${ }^{3}$

Parochial confession was a key subject of late medieval literature. Sermon exempla and poetry draw on the liturgy and doctrine of penance, but they also imagine its parochial setting, paying special attention to the material space and fabric of the parish as well as the symbolic function these might play in a layperson's journey from sin to salvation. In Handlyng Synne, Robert Mannyng figures penance as site-specific, concentrating on its physical setting in order to explore the efficacy of parochial confession and, even more significantly, to explore the role that thresholds such as the churchyard gate or the church door might play in repelling the devil and ushering laypeople to salvation. For Mannyng, parochial space plays a crucial role in the sacrament of penance and the very making of the parish and the community of the saved. But even though penance was closely associated with the parishwhether in conciliar literature or in vernacular sermons-the advent of the friars brought more and more opportunities for confession outside of the context of the parish. ${ }^{4}$ Indeed, the parish is often figured as shockingly vulnerable in the context of penance, particularly when extraparochial figures such as friars were elbowing their way into the church or, even worse, when penance was wrested away from the parish entirely. William Langland imagines a weak and porous parish, encumbered and enfeebled by the advent of the friars and their filching of pastoral offices. Throughout Piers Plowman, he turns to the metaphor of horticultural grafting as a way to illustrate the damaging

3. On the penitential production of the subject and, more particularly, the subject in relation to power, see Lochrie, Covert Operations, 20-21; Little, Confession and Resistance, 11-12.

4. Tentler, Sin and Confession, 64-65. Margery Kempe famously made confession multiple times a day. Book of Margery Kempe, lines 368-69, 1159-60. 
consequences of the friars' physical violation of the parish and their appropriation and abuse of parochial confession.

\section{The Parochial Context of Confession}

Confession was a central part of parochial devotion and it was understood as a fundamentally collective enterprise, due in no small part to the Fourth Lateran Council of 1215. Canon 21-also known as Omnis Utriusque Sexusfamously mandated annual individual confession. It also parochialized penance, making it a tool for shaping the parish and its membership and, by prescribing its timing and location, making confession a shared obligation and a public rather than private act:

All the faithful of either sex, after they have reached the age of discernment, should individually confess all their sins in a faithful manner to their own priest at least once a year, and let them take care to do what they can to perform the penance imposed on them. Let them reverently receive the sacrament of the Eucharist at least at Easter unless they think, for a good reason and on the advice of their own priest, that they should abstain from receiving it for a time. Otherwise they shall be barred from entering a church during their lifetime and they shall be denied a Christian burial at death. Let this salutary decree be frequently published in churches, so that nobody may find the pretence of an excuse in the blindness of ignorance. If any persons wish, for good reasons, to confess their sins to another priest let them first ask and obtain the permission of their own priest; for otherwise the other priest will not have the power to absolve or bind them. The priest shall be discerning and prudent, so that like a skilled doctor he may pour wine and oil over the wounds of the injured one. Let him carefully inquire about the circumstances of both the sinner and the sin, so that he may prudently discern what sort of advice he ought to give and what remedy to apply, using various means to heal the sick person. Let him take the utmost care, however, not to betray the sinner at all by word or sign or in any other way. If the priest needs wise advice, let him seek it cautiously without any mention of the person concerned. For if anyone presumes to reveal a sin disclosed to him in confession, we decree that he is not only to be deposed from his priestly office but also to be confined to a strict monastery to do perpetual penance. ${ }^{5}$

5. "Omnis utriusque sexus fidelis, postquam ad annos discretionis pervenerit, omnia sua solus peccata confiteatur fideliter, saltem semel in anno proprio sacerdoti, et iniunctam sibi 
Canon 21 makes penance a parochial endeavor first and foremost by repeatedly stipulating its performance in the presence of one's own parish priest. Although scholars have long acknowledged the "social dimension"6 of confession, late medieval penance has often been misconstrued as a fundamentally private act. Misleading translations of the word solus as "private" may have something to do with modern misconceptions of confession as a private rather than public and social act. Tentler, for example, claims that canon 21 made "private confession [. . .] universally obligatory." But solus refers to the individual nature of the encounter between priest and penitentthe "loneliness" of it, as Mansfield suggests_rather than a sense of privacy or secrecy. ${ }^{8}$ As others have observed, canon 21 establishes the authoritative role of the priest in the penitential process, characterizing the ideal practitioner as a cautious and discerning medic who carefully heals his wounded congre-

poenitentiam studeat pro viribus adimplere, suscipiens reverentur ad minus in pascha eucharistiae sacramentum, nisi forte de consilio proprii sacerdotis ob aliquam rationabilem causam ad tempus ab eius perceptione duxerit abstinendum; alioquin et vivens ab ingressu ecclesiae arceatur et moriens christiana careat sepultura. Unde hoc salutare statutum frequenter in ecclesiis publicetur, ne quisquam ignorantiae caecitate velamen excusationis assumat. Si quis autem alieno sacerdoti voluerit iusta de causa sua confiteri peccata, licentiam prius postulet et obtineat a proprio sacerdote, cum aliter ille ipsum non possit solvere vel ligare. Sacerdos autem sit discretus et cautus, ut more periti medici superinfundat vinum et oleum vulneribus sauciati, diligenter inquirens et peccatoris circumstantias et peccati, per quas prudenter intelligat, quale illi consilium debeat exhibere et cuiusmodi remedium adhibere, diversis experimentis utendo ad sanandum aegrotum. Caveat autem omnino, ne verbo vel signo vel alio quovis modo prodat aliquatenus peccatorem, sed si prudentiori consilio indiguerit, illud absque ulla expressione personae caute requirat, quoniam qui peccatum in poenitentiali iudicio sibi detectum praseumpserit revelare, non solum a sacerdotali officio deponendum decernimus, verum etiam ad agendam perpetuam poenitentiam in arctum monasterium detrudendum." Latin text and English translation are from Decrees of the Ecumenical Councils, 245-46. On canon 21, see Mansfield, Humiliation of Sinners, 66-78; Tentler, Sin and Confession, 21-22, 60-61; Tanner and Watson, "Least of the Laity: The Minimum Requirements for a Medieval Christian," 405-8.

6. John Bossy emphasizes the sacrament's "social dimension as both a prerequisite to communion and as a means of entry into broader Christendom" in "Social History of Confession," 22. Lochrie has argued more recently that, in making confession a prerequisite for Easter communion, the "conjunction" of these two sacraments-Confession and Eucharist-effectively made confession an essential part of the "social act" of Easter communion. Covert Operations, 25. Rubin takes a different approach, arguing that "penance was essentially private," but it gave access to the communal celebration of the Eucharist and to "universal" salvation. Corpus Christi, 84-85.

7. Tentler, Sin and Confession, 16.

8. Mansfield observes that the "ordinary term" for describing private penance is penitentia privata, and that the usage of solus is "without parallel in contemporary theology and canon law." Humiliation of Sinners, 66-67. Schroeder's translation dodges the issue by avoiding the word solus altogether: "All the faithful of both sexes shall after they have reached the age of discretion faithfully confess all their sins at least once a year to their own (parish) priest." Disciplinary Decrees of the General Councils, 259. 
gants. ${ }^{9}$ Beyond defining the relationship between priest and penitent, however, canon 21 also characterizes penance as an act that shapes and regulates parochial space and community, particularly because it serves as a gateway to both communion and burial.

In the decades before confessional boxes came into use, confession probably took place in the nave, either on the steps leading up to the chancel or in a side chapel. ${ }^{10}$ Late medieval visual sources often foreground the powerful link between penance and public parochial space. Representations of confession regularly appear, for example, on baptismal fonts alongside carved depictions of the other sacraments. ${ }^{11}$ Such a context underscores the fact that baptism offers the potential for salvation-a potential that can only be achieved through a lifetime of regular penance. The scenes carved into fonts regularly convey the collective nature of penance by carefully situating the sacrament in parochial space, often with detailed architectural frames that evoke the bays and semi-enclosed chapels of the nave aisle. Tom Elich has argued that these scenes also draw attention to "the communal dimensions of reconciliation" by depicting images of penitents who wait their turn. ${ }^{12}$ Rubbing elbows with one's neighbors during confession seems to have been part of the point of parochial penance: French theologian Jean Gerson explained in the mid-fourteenth century that confession was to be "made in a public space" so that "everyone should be able to see and understand it." ${ }^{13}$

Late medieval laypeople made a public confession alongside their fellow parishioners every time they went to Mass, joining the priest in the recitation of the Confiteor, a collective confession of sins in preparation for the Mass proper. ${ }^{14}$ A kind of supplementary form of penance that helped stave

9. Lochrie discusses the traditional motif of the "confessor/physician" in Covert Operations, 26.

10. On the sixteenth-century invention of the confessional box by Carlo Borromeo, Archbishop of Milan, and its general appearance throughout northern Europe thereafter, see Bossy, "Social History of Confession," 28-33. Jeremy Tambling explores the confessional box as a symbol of the panopticon in Confession: Sexuality, Sin, and the Subject, 66-70. See also Senior, In the Grip of Minos, 78-85.

11. Nichols, Seeable Signs, 222-41; idem, "Etiquette of Pre-Reformation Confession," 155.

12. Tom Elich, "Communal Reconciliation," 139. See also Nichols, "Etiquette of PreReformation Confession," 155-61 (and figs. 11-12). Waiting penitents also appear in the illuminations that accompany entries for confession and contrition in the fourteenth-century Omne Bonum (c. 1350-75). Sandler, Omne Bonum, 1:22, 26. See f.354v, f.357, and f.368v (2:123-24) for images of confession, and f.414v (2:133) for contrition.

13. Quoted in Root, "Space to Speke," 72. On French synods and their stipulations about the public space of confession, see Mansfield, Humiliation of Sinners, 79; Tanner and Watson, "Least of the Laity," 407.

14. The Confiteor was standardized by the Council of Ravenna in 1314 and marked the beginning of the Mass in secular usage. Jungmann, Mass of the Roman Rite, 1:280; Dallen, 
off temptation from one Easter penitential season to the next, the Confiteor offered an expression of individual penance in a communal context and signified the restoration and reconciliation of the congregation as a whole. ${ }^{15}$ Indeed, this reconciliation was physically reinforced both bodily and verbally. In the Lay Folks Mass Book, an early fourteenth-century guide to the Mass, the Confiteor is associated with collective kneeling and prayer among the members of the congregation. ${ }^{16}$ Once the priest has begun his own confession, a moment signaled when he "haldes to god vp bothe his handes," parishioners are instructed to kneel and begin theirs. "Knelande on pi knese," the Lay Folks Mass Book prescribes,

als pou bisyde pe oper sese,

shryue pe pere of all pi synnes,

bigynnande pus when [the priest] bigynnes. ${ }^{18}$

Kneel on your knees, as you see others beside you doing. Confess yourself of all of your sins, beginning at the same time as the priest.

The choreography of this mutual confession works to frame the Mass as a social enterprise, but even more importantly, it shapes the parish as a penitential community, all kneeling together to confess. The book's English translation $^{19}$ of the Confiteor reinforces the collective context of penance by shifting between singular and plural, "I" and "we." The prayer's opening statement in the first person- "I know to God" that "I have synned"-is underscored by a

Reconciling Community, 127-28; Dudley and Pinnock, "Rites of Penance and Reconciliation," 182. On the representation of the Confiteor in an illustrated Mass tract from the 1320s, see Kumler, Translating Truth, 124.

15. The early fourteenth-century Book of Penance describes "be Confiteor pat es / Wont to be said at pe messe" as one of several ways to satisfy one's penance for confessed sins. Extant in six manuscripts, the Book of Penance is printed in part 5 of Morris's edition of the Cursor Mundi, lines 25684-29555 (at 28582-83). Trudel discusses the different versions and their manuscript contexts in "Middle English Book of Penance," 12-14. Chaucer's Parson lists the "general confessioun of Confiteor at masse" among other preventative measures against venial sin. Canterbury Tales, fragment 10, line 385.

16. The Lay Folks Mass Book survives in nine fourteenth- and fifteenth-century manuscripts of broad distribution. Raymo, Manual of the Writings, 2350-51, 2555-56.

17. Lay Folks Mass Book, 6 (line 40).

18. Ibid., 6 (lines 53-58).

19. The author of the Lay Folks Mass Book explains that, although "many saien confiteor"that, is the Latin version of the prayer-reciting the vernacular version "were als gode." Ibid., 8 (lines 63-64). For a recent discussion of the church's efforts to accommodate a broad range of "discourse communities" and "ensure that participation was as extensive as possible," see Swanson, "Prayer and Participation," 131, 134. 
proliferation of objective and possessive pronouns in the first-person singular: the penitent asks the priest to "praye for me," to "gyue me grace and forgyueness / of my mys-dede." And yet it also positions the speaking individual before a broad group of listeners that includes not only the parish priest but also God, Mary, and All Hallows. ${ }^{20}$

The Lay Folks Mass Book makes the communal context even more explicit by shifting from the first-person singular to first-person plural ("we") and the plural objective ("us," "us alle") in the unnamed Middle English prayer that follows the Confiteor. Congregants mark this turn from the individual to the collective with a change of posture. Having recited the Confiteor and the Creed, kneeling penitents are instructed to stand up: "When pou pi crede pus has done, / vp-on pi fete pou stande vp sone." ${ }^{21}$ The vernacular prayer that they then recite begins with a general plea to God on behalf of the priest and the congregation and articulates four different groups of listeners: those standing in earshot of the nave (all "pate hit shal here" during the Mass), those in heaven (God, his "modir," and his "halouse [hallows]"), friends and family members ("sib or fre[n]de bi ony kynde"), and, finally, the dead ("cristen soules passed away"). ${ }^{22}$ These last two groups draw particular attention to the parish, an extended community that, as we saw in chapter 1, included a person's familial and spiritual kin, both living and dead. From beginning to end, the prayer not only broadens from individual to community but also moves up and down a vertical axis from the heavens to the parish, locating the penitent in relation first to God and priest, then to Mary and the saints, and finally in relation to his fellow Christians, both living and dead. Together, the two prayers move from the first-person singular to the collective "we," making the

20. "I know to God, ful of myght, / \& to his modir mayden bright, / \& to alle halouse here, / \& to pe, fadre gastly, / pat I have synned largely. / In mony synnes sere: / In thoght, in speche, \& in delite, / In worde, \& werk I am to wite / And worth to blame; / Per-fore I praie saynt mary / And alle halouse haly, / In gods name, / And po preste to praye for me, / Pat god haue merci \& pyte, / For his manhede, / Of my wreched synfulnes, / \& gyue me grace \& forgyuenes / of my mys-dede. Pater. Aue. Credo." Lay Folks Mass Book, 8-10 (lines 65-82).

21. Ibid., 10 (lines 83-84).

22. "God, for pi godnes, / at po bigynnyng of pis mes, / graunt alle, pate hit shal here, / of conscience be clene \& clere; / lord, saue po prest pat hit shal say, / fro temptacions to day, / pat he be clene in dede \& poght, / pat yuel spiritis noy him noght, / pat he fulfille pis sacrament / with clene hert \& gode entent, / first heghly to pin honoure, / pat souerayne is of al socoure; / \& to pi modir, mayden clene, / \& to pi halouse alle bi-dene; / \& to alle pat heres hit, soul hele, / helpe \& grace \& al kyns wele; / and to alle pate we haue in mynde, / sib or fre[n]de bi ony kynde, / god lord graunt hom for pis messe / of alle hore synnes forgyfnesse; / And rest \& pese pat lastis ay, / to cristen soules passed away; / and til vs alle pi socoure sende, / \& bring vs to ioy with-outen ende. Amen." Ibid., 10-12 (lines 91-114). Simmons notes that this post-Confiteor prayer "occupied the time between the office and the Epistle, except when the Gloria in exclesis was sung.” Ibid., 191. 
parish as a whole the object of penitential prayer as the congregation finally asks God to bring comfort and joy to everyone: "And til vs alle pi socoure [relief] sende, / \& bring vs ioy with-outen ende." ${ }^{23}$ This collective emphasis is underscored in another late medieval handbook on the Mass, which warns penitents against praying only for themselves during the Confiteor: "And ze preye but only / For zor owne hele [healing]," the author chastises readers, "3e beo not worp so muche meede [reward]." ${ }^{24}$

While the Confiteor emphasizes inclusivity as it works to situate the individual layperson within a much broader penitential community, other expressions of penance drew attention to the unconfessed sinner's potential exclusion from that community. Looking once more at the Fourth Lateran Council, canon 21 imagines this circumscription in explicitly ritual and spatial terms, mandating that those who fail to make confession and, subsequently, Eastertide communion, are "barred from entering a church" and "denied a Christian burial at death." ${ }^{25}$ This exclusion extends to priests, too. Those who betray the confidence of their congregants will be deposed and, moreover, evictedthrust out of the parish (detrudendum) and locked away in monasteries.

The specter of exclusion is also central to representations of the Palm Sunday procession in vernacular sermon collections. According to the Speculum Sacerdotale (c. 1425), penitents who had confessed ahead of time were publicly rewarded a week before Easter during the Palm Sunday procession. As the congregation gathered in the churchyard, those who had already confessed were invited to join the Palm Sunday procession and "bere [their] palme[s]." ${ }^{26}$ For those who had not yet been absolved, the palms were a vivid reminder of the urgency and efficacy of confession and a motivating nudge for as-yet unconfessed penitents in the final countdown to Easter communion. As John Mirk explains in the Palm Sunday sermon from his Festial (c. 1385-90),

Iche criston man and womman schal pis day beron palmus in processioun, schewing pat he hathe fowton wyth pe fende, and hath pe victorye of hym bi clene schryuing of mowpe, repentaunce of herte, and mekely done his penaunce. $^{27}$

23. Ibid., 12 (lines 113-14). Edden argues that the liturgy "combined private and communal religion" and that "the language of hymns often expresses shared experience." "Devotional Life of the Laity," 38 .

24. The Manner and Mede of the Mass (c. 1375) has been edited by Simmons and appears at the end of his edition of the Lay Folks Mass Book, 128-47 (at 133, lines 198-99, 201).

25. "Alioqun et vivens ab ingressu ecclesiae arceatur et moriens christiana careat sepultura." Decrees of the Ecumenical Councils, 245-46.

26. Speculum Sacerdotale, 98 (lines 16-17).

27. Mirk, Festial, 102 (lines 53-57). 
Each Christian man and woman shall on this day hold palms in procession, in order to show that he has fought with the fiend and had victory over him by making an oral confession, by experiencing heartfelt repentance, and by meekly undertaking penance.

In both sermons, the palm makes penance visible and demonstrates the central social role that it plays in shaping and constituting the parish community. The procession negotiates the relationship between the individual penitent, the wider Christian community, and the physical space of the parish church. Indeed, while only the cleanly confessed palm bearer earns a place in the procession, all those who confess in time for Easter communion earn, at the very least, the right to an unmarked grave in the parish churchyard.

The threat of exclusion looms much larger in the General Sentence, a ceremony celebrated up to four times per year, during which the priest read a detailed list of excommunicable offenses and performed a symbolic dramatization of excommunication, all in order to encourage his parishioners to confess their sins. While the Confiteor emphasizes the Christian community at its most inclusive, from the kneeling penitent in the parish nave to the broader circle of All Hallows in heaven, the General Sentence explores the terrifying threat of disbarment from this community. The basic structure of the ceremony-an anonymous list of excommunicable offenses or, as Swanson has described it, a "roll-call of failings" followed by a formal curse-was promulgated by English Archbishops beginning in the last quarter of the twelfth century. ${ }^{28}$ The 1222 Council of Oxford advocated recitation four times per year, ${ }^{29}$ and in 1289, a Winchester Council instituted the reading of the General Sentence in the vernacular, prompting widespread circulation of the ceremony in the centuries that followed. ${ }^{30}$

The General Sentence was part of the standard repertoire of catechetical teaching and appears in several pastoral handbooks alongside instruction on the basic tenets of the faith. ${ }^{31}$ The best-known versions of the General Sen-

28. Swanson, Religion and Devotion in Europe, 61.

29. Councils and Synods, 2:106-8, 125.

30. Ibid., 2:1089. In 1434, Archbishop Chichele issued an "abbreviated English form" of the General Sentence, which circulated in both manuscript and print. Register of Henry Chichele, 3:6, 222-23. Little discusses the sixteenth-century "Service of Commination," which appeared in the first two editions of the English Book of Common Prayer, in an appendix to Benedictine Maledictions, 272-74. Despite its continued revision and circulation in both manuscript and print well into the sixteenth century, the Middle English texts of the General Sentence have never been the subject of a literary study. The most useful source on the subject remains Pickering's catalogue and description of more than forty manuscript copies in "Notes on the Sentence of Cursing in Middle English," 229-44.

31. Pickering lists four manuscripts in which "the Sentence forms part of a manual for parish priests in English prose that also deals with the Lord's Prayer, the articles of the faith, 
tence appear in copies of John Mirk's late fourteenth-century Instructions for Parish Priests, in which a brief preface in verse is followed by a comprehensive list of curses and a description of the priest's closing gesture with candle and bells. ${ }^{32}$ The ceremony is framed as a parochial enterprise: the introduction recommends recitation of "this idous thing" two or three times a year, "whan thi parisse is togidir mette," with "crosse \& candell and bell knylling." ${ }_{33}$ After an exhaustive and wide-ranging catalog of punishable offenses-from sacrilege, slander, and usury to coin-clipping, eavesdropping, and child abandonment-perpetrators are "departe[d] from alle gode dedes and preres of holy chirch, and of all pes halowen," and "dampne[d] into pe peyn of hell." ${ }^{34}$ In denying offenders any benefits from the Mass, or from prayer or good deeds, the curse cuts them off from the church, revoking their Christian membership. The General Sentence marshals the extended community of Christendom, promulgating the curse "by the aucthorite of the father and of the son and of the holy goost and of our lady Seynt Mary goddes moder, of heuene, and all oper virgines and Seynt Mighele and all oper apostles and Seynt Steven and all oper martires, and Seynt Nicholas and all oper confessoures \& of all the holy hallowen of heuen." ${ }^{35}$ God, Mary, the saints, and all Christian souls-the group recalls the broad community assembled in the Confiteor, threatening listeners with the terrifying possibility of disenfranchisement.

The General Sentence makes dramatic use of the space and fabric of the church itself. It ends with a spectacular moment of spitting, candle dashing, and, once again, bell ringing:

Than pou thi candell shalt cast to grounde

And spet therto pe same stound

the commandments, the vices and virtues, the sacraments, etc." Ibid., 230. In addition to reciting the General Sentence several times throughout the year, priests were also incorporating instruction on excommunicable sins into their sermons, particularly during the weeks leading up to Easter: in his Lenten sermons, Mirk repeatedly exhorts his listeners to make confession and to remain vigilant against the devil's virulent attacks during "bese fourety dayes." Festial, 79 (line 55). See also Jacob's Well, where the "Exhortacio contra articulos sentencie excommunicacionis maioris" has been stretched across four chapters, a suggestive division that points toward the four Sundays preceding Easter. Jacob's Well, 5-36.

32. Mirk, Instructions for Parish Priests, ed. Peacock, lines 675-786. The General Sentence appears in three of the seven copies of Mirk's Instructions: Oxford, Bodleian Library MS Douce 60; Oxford, Bodleian Library MS Douce 103; London, British Library MS Cotton Claudius AII. A fourth copy of the Festial (Cambridge University Library MS Ff.5.48) includes a heading for the General Sentence but is followed only by blank lines. For further discussion of these copies, see Mirk, Instructions for Parish Priests, ed. Kristensson, 12-13; Pickering, "Notes on the Sentence of Cursing," 229-30.

33. Mirk, Instructions, ed. Peacock, lines 678-80.

34. Ibid., lines 756-57.

35. Ibid., lines 750-55. 
And lete also pe belles knylle

To make her hortes the mor grylle. ${ }^{36}$

Then you should cast your candle to the ground and spit. And let the bells toll in order to make their hearts more sorrowful.

This final gesture functions as a symbolic excommunication that reminds parishioners of the dangers of heinous sin. A rare piece of commentary on the ceremony from a fifteenth-century register draws an analogy between the dashed candle and the excommunicant: "Rizt as pis Candelle is qwenched and departed fro lizt: so pei for to be departed fro god pat is lizt of pis worlde for euer and to dwelle in helle all way in derkenesse without end." ${ }^{37}$ The setting - a parish church packed with people-emphasizes the sinner's exclusion from the parish community and its benefits, while the bells tolling in the background sound a kind of spiritual death knell, a terrible reminder of the finality of excommunication..$^{38}$ And yet the ceremony also reminds wrongdoers that exclusion need not be permanent: sinners are "put oute of the boke of lyfe," but only "tyll they come to amendment," a phrase that appears twice in the curse. ${ }^{39}$

A powerful image of the candle-dashing spectacle and its endorsement of parochial penance as a means to salvation appears in the fourteenth-century Omne Bonum, an illustrated compendium of information on a wide variety of subjects, including law, theology, biblical history, and the natural world (fig. 3)..$^{40}$ Alongside the entry for excommunication, a historiated letter E (for excommunicacio) is illuminated with a scene in which a priest stands in a pulpit, candle in hand, before a crowd of plainly dressed male and female laypeople, one of whom holds a rosary. ${ }^{41}$ With all eyes focused on the priest's raised candle, the miniature captures the moment just before the spitting and candle-dashing spectacle while also looking ahead to the possibility of penance and reconciliation among members of the congregation. The enormous

36. Ibid., lines 777-80.

37. English Register of Godstow Nunnery, 3 (lines 35-38).

38. On the use of bells in funerary ritual, see Walters, Church Bells of England, 152-64. Bells were often the product of large-scale lay fundraising. French, People of the Parish, 100, 143-47.

39. Helmholz discusses the General Sentence as a warning rather than a curse in "Excommunication in Twelfth-Century England," 237-40.

40. Sandler, Omne Bonum, 1:13.

41. The artist represents several different ceremonies over the course of the book. Sandler argues that while images of betrothal and marriage are "regularly illustrated in law books," there is less visual evidence for the other rituals depicted in the compendium. The illustrations "could well have come from other sources familiar to the artist," Sandler suggests, "not excluding, of course, his own experience of these ceremonies." Ibid., 1:90. 


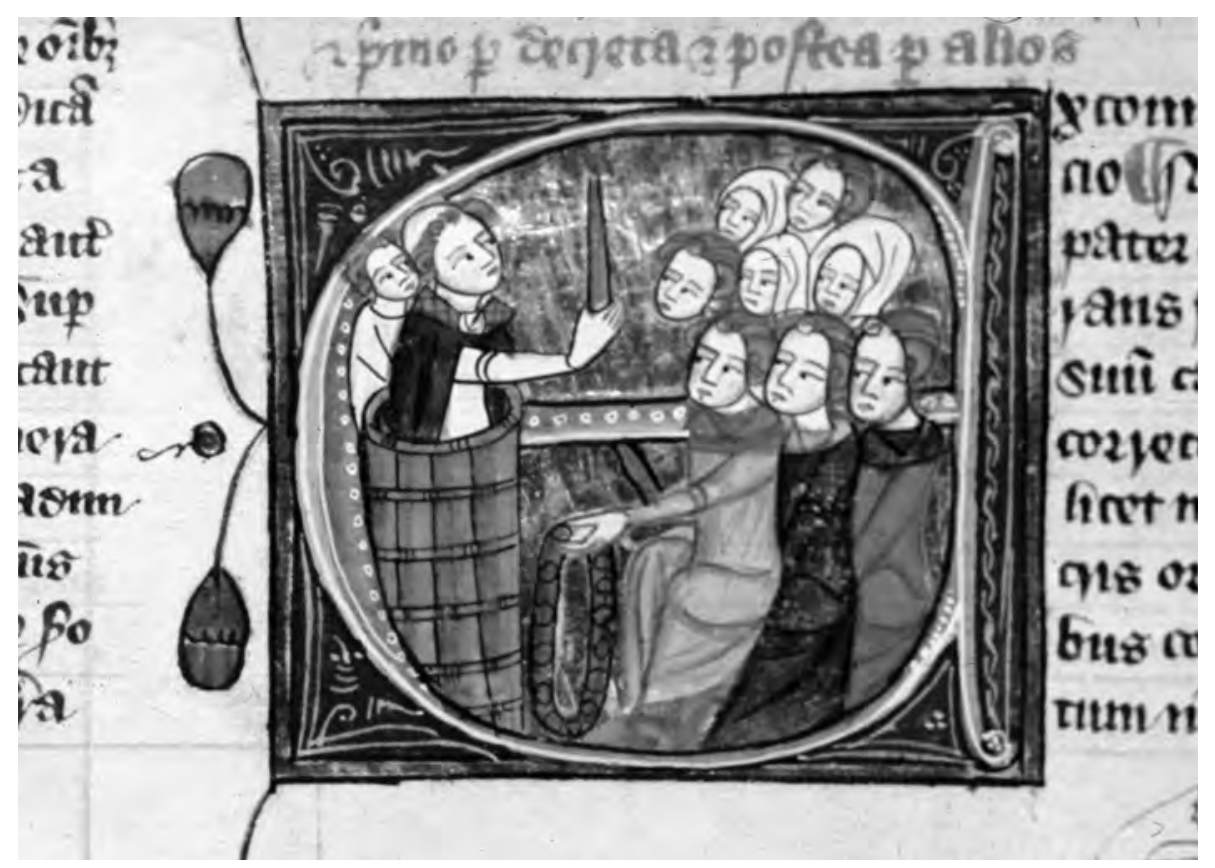

Figure 3. Priest addressing a congregation. Omne Bonum, entry for Excommunicacio [Excommunication]. () The British Library Board, MS Royal 6 E VII (c. 1350-75), fol. 75v.

rosary in the foreground offers a powerful visual reminder of the exhortative "tyll"-clause that appears throughout Mirk's version of the General Sentence; it counterbalances the candle, translating the utility of penance into visual terms. ${ }^{42}$ Together, the two objects divide the image in half, setting up a lateral opposition between priest and laity that replicates the traditional architectural distinction between clerical and lay space-chancel and nave-in the late medieval parish. ${ }^{43}$ The central axis formed by candle and rosary perhaps also gestures to the Last Judgment and to the separation of the saved from the

42. Sandler observes that, "although the devotion to Christ and the Virgin that is associated with the counting of the beads of a rosary arose during the thirteenth century, the representations of rosaries in the Omne Bonum are extraordinarily early, and provide heretofore unrecognized visual evidence of the prevalence of this practice in England at this time." Ibid., 1:107. See also Winston-Allen, Stories of the Rose, 12-18.

43. French, People of the Parish, 154-55. Jung argues that the "dual role" of the choir screen encompasses both "its physical function as a divider of space and social groups" and "its liturgical function as a uniter of spaces and groups through the ritual of the Mass." "Beyond the Barrier," 630. 
damned, an opposition underscored by the crosspiece of the E, which divides the upper and lower halves of the image. Canon 21 parochialized penance by regulating the timing and location of the sacrament. It also established a connection between penance and parochial space by making the sacrament a prerequisite for burial and by barring uncooperative penitents-and priests, for that matter-from entering churches. From the Confiteor to the Palm Sunday procession and even the General Sentence, medieval liturgy represents penance as a collective enterprise that shapes and regulates the parish community. Perhaps especially in the General Sentence and in the Omne Bonum's representation of excommunication, parochial space itself plays an important role in the penitential process.

\section{Handling Sin in Parochial Space}

In the prologue to his early fourteenth-century handbook Handlyng Synne, Robert Mannyng repeatedly calls attention to parochial space when treating the subject of penance and the idea of "handling" of $\sin .{ }^{44}$ The term "handling" comes from Mannyng's Anglo Norman source text, the Manuel des Péchés, a text so titled in reference to its portability as a handbook or manual: "Le Manuel est apelé, / Car en main deit estre porté" 45 [It is called a manual because it can be carried by hand]. In one sense, the act of handling sin concerns the physical use of the book itself; as Mannyng notes in the prologue, the "skyl" of handling sin involves the careful reading and rereading of the handbook. He explains, however, that sin must also be handled through oral confession, a practice that he closely associates with the parish and its priest, the only figure who can help a penitent move from handling to absolving. ${ }^{46}$ Indeed, he unequivocally endorses parochial confession: "Alle prestes haue nat powere / For to assoyle [absolve] pe ryght clere," he warns, "but hyt be py

44. Mannyng, Handlyng Synne, ed. Sullens, line 83. Robertson argues that the book models the process of "handling" sin for its readers: "Handlyng Synne 'handles' sinful actions so that the reader may 'handle' them in thought and finally 'handle' them at confession." "Cultural Tradition of Handlyng Synne," 167.

45. Waddington, Manuel des Péchés (in Mannyng, Handlyng Synne, ed. Furnivall), 4 (lines 63-64). Of Shrifte and Penance, a lesser-known prose translation of the Manuel des Péchés that survives in a single manuscript, stays much closer to the Anglo-Norman original: "Pe Manuel hyt is called, for in pe honde hyt schulde be bore." Of Shrifte and Penance, 34. On Mannyng's assumption that readers have access to a physical copy of the book, see Scott, "For Lewed Men Vndyr Toke," 386.

46. A noupyr handlyng per shulde be / Wyp shryfte of moupe to clense pe [...] Pys ys a skyl pat hyt may be tolde / Handlyng synne many a folde." Mannyng, Handlyng Synne, lines 97-98, $113-14$. 
parysshe preste." ${ }^{77}$ The book aims to teach readers to manage their spiritual health through careful self-reflection, but it does so while also establishing a central role for the parish and its priest in the penitential process.

Storytelling is central to Mannyng's efforts to teach his lay audience how to handle sin. Sermon exempla are perhaps particularly well suited for grappling with penance and the parish because they were, in fact, already framed by both: designed for use in sermons, they address a parochial audience in a church and in the context of the Mass, a service that was itself framed in penitential terms through the opening Confiteor. ${ }^{48}$ As many have observed, Handlyng Synne covers the basic syllabus of lay instruction outlined by the Fourth Lateran Council in 1215, treating such subjects as the Ten Commandments, the Seven Deadly Sins, and the Sacraments. ${ }^{49}$ At the end of the book, Mannyng devotes nearly 1,500 lines - about a tenth of the book-to penance and, especially, confession..$^{50}$ Mannyng divides the section on "shryfte" into twelve points and eight graces-the points describing the ideal conditions in which to make confession (with good will, for example, and as soon as possible after committing a sin), and the graces cataloging its many positive benefits (confession heals the soul, kills the devil, brings joy to heaven). In treating the seventh grace of confession (it blinds the devil), Mannyng tells a story that uses the negotiation of parochial spaces and thresholds to conceptualize the layman's progression from sin to absolution..$^{51}$ The story is told from the perspective of a hermit who, stationed in the churchyard, monitors the daily traffic of parishioners. One day, while watching "be folke pat come in pe gate," he

47. Ibid., lines 11611-13.

48. Larry Scanlon argues that the "the exemplum's status as narrative gave it an ideological power doctrine often lacked." Narrative, Authority, and Power, 27-36 (at 31). In his analysis of Mannyng's story about the Dancers of Colbek, Miller claims that exempla are concerned more with "engaging the territory of agency than with defining a range of transgressions and appropriate penalties." "Displaced Souls," 608. Allen explores medieval exemplary narratives, their audiences, and the "moral consequences of reading" in False Fables and Exemplary Truth, 25. On the "interpretive" function of the exemplum in relation to biblical narrative, see Little, Confession and Resistance, 24-25. Scott has recently argued that the plethora of exempla in Handlyng Synne reflects Mannyng's aim "to compete for the laity's attention by providing his own tales to rival the usual literary entertainment of ordinary people." "For Lewed Men Vndyr Toke," 385.

49. Ibid., 381; Robertson, "Cultural Tradition of Handlyng Synne," 171-72. Garrison explores Mannyng's treatment of the Eucharist in relation to thirteenth-century discussions of transubstantiation, including the first canon of the Fourth Lateran Council. "Mediated Piety," 899-905.

50. Mannyng, Handlyng Synne, ed. Sullens, lines 10819-950 (on the sacrament of Penance), 11311-2638 (on confession). All quotations from Handlyng Synne have been taken from the Sullens edition. Hasenfratz argues that fear is central to the book's efforts to redirect readers and listeners from sin to confession. "Terror and Pastoral Care," 148.

51. Mannyng, Handlyng Synne, lines 12171-260. 
sees a man shackled to the devil..$^{2}$ As the chained pair make their way through the gate and into the churchyard, the devil stops dead in his tracks, unable to enter the church itself:

As [the hermit] stode, he toke gode hede

How a deuel, a man gan lede.

With hym he com al weyl pe gate

And ledde hym to pe chyrche zate.

And ynto pe cherche zerd

Ferper durst he nat for ferd,

And whan he in to pe cherche shuld go,

pan brast pe fendes chayne in two.

pe fende stode stylle \& loked aboute

And abode pys man wypoute.

On hys clawes he helde pys cheyne

And loked what tyme he com azeyne. ${ }^{53}$

As he stood, he noticed a devil who was leading a man who had a gone astray. The devil led him to the churchyard gate and into the churchyard, but he was afraid to go any further. When the man entered the church, the devil's chains broke. The devil stood there, looking around as he waited outside for the man; in his claws he held the chains as he waited for the man to return.

In rhyming gate and zate, Mannyng wastes no time in highlighting the relationship between spiritual status and movement through parochial space. The chained pair have come "weyl pe gate," which is to say they have gone astray: in Middle English, gate can refer to a path or to a manner of walking (a gait), and wilgate to taking a wrong turn. ${ }^{54}$ Their sinful travels end at an altogether different kind of gate, however, one that opens onto a parish churchyard. Mannyng pays meticulous attention to the pair's parochial itinerary and to the devil's ultimate exclusion from the parish church. Having passed through the churchyard gate and into the churchyard proper, the devil is overcome with fear and can go no further. When the layman enters the church, the shackles "brast," leaving the devil "wypout," broken chain in hand. Before arriving at

52. Ibid., line 12183 .

53. Ibid., lines 12189-200.

54. MED, "wil," 1a: "Wandering, straying, lost; also fig.; of wealth: gone; gate, a wrong turn; of gate, wandering from (one's) direction." OED, “will," adj., 3c: "will gate," and "gate will," meaning "going astray." 
the gate, man and devil are rendered nearly indistinguishable by Mannyng's spray of pronouns. But their identification proves no stronger than the chain that yokes them together-it breaks, and the two become separate entities again, "pe fende" and "pys man." The layman keeps moving, purposefully, from gate to church door, but the devil is stuck, his stasis pointing back to the sinful wandering gait that defined both devil and man at the story's beginning. The devil becomes not only paralyzed, but blind: awaiting his former charge, he searches in vain as the church doors open at the end of the service. When the onlooking hermit asks him what he is doing in the churchyard, the devil explains that he has been waiting for his "prysun," his prisoner:

Langer wente he yn fro me;

He com nat out 3yt pat y may se.

Among manye y haue hym soght:

Me pynk wndyr, y fynde hym noght. ${ }^{55}$

He left me to go inside a long time ago and has not come out since, as far as I have seen. I have looked for him among the crowd; I think it a wonder that I have not found him.

Scanning the parishioners as they exit the church, the devil is unsuccessful in his efforts: "Pe syghte of hym hadde he lore [lost]," Mannyng writes." ${ }^{56}$

The blinding of the devil neatly illustrates an earlier point that Mannyng makes when discussing the virtues of confession. "We putte out hys ye gostly," he writes, "Whan we shryue vs opunly. / Certes he may nat knowe vs efte / For oure shryfte hap hym pe syghte refte." ${ }^{77}$ Seeing one's own sins and making them known to a priest through confession incapacitates the devil-he no longer "knows us," Mannyng claims, no longer sees us. What's more, confession prevents him from being able to "know" laypeople the way a priest can. Mannyng's devil stands in stark contrast with, for example, a parish priest we encounter earlier in the handbook who has been graced with the ability to see his parishioners' sins painted on their faces. ${ }^{58}$ This priest possesses many of the ideal qualities outlined in canon 21: A "man of ful gode dyscrecyoun," Mannyng's thoughtful priest seeks to understand his parishioners and to know- "ryghtly to ges"- which were "ylle" and which were "gode." 59

55. Mannyng, Handlyng Synne, lines 12226, 12229-232.

56. Ibid., line 12215.

57. Ibid., lines 12165-68.

58. Ibid., lines 10167-260.

59. Ibid., lines 10168-72. 
As Easter approaches, however, the priest worries about two of his parishioners. Anxious that they might take communion without having fully confessed their sins, he asks God for the ability to diagnose his parishioners' inner spiritual health by reading their bodies. The story calls attention, of course, to the danger of taking communion while in a state of sin, and it highlights the crucial role that priestly discernment plays in ushering laypeople to salvation. More than a cautionary tale for unconfessed penitents, this is a story about the parochial penitential process which, as a requirement for worthy communion, shapes the community of the saved. The work of the priest is site-specific: his diagnostic skills are put into practice in the parish nave, as if the space were a direct conduit between God and the mind of the priest. Only a parish priest can absolve a person's sins, Mannyng explains, and only in the parish can confessors wield their God-given diagnostic skills. ${ }^{60}$

Parochial confession thus endows priests with powers of discernment but blinds the devil, who can see only sin. In Mannyng's exemplum about a layman's unshackling, the devil loses sight of his former captive, unable to find him when he exits the church cleanly confessed. The devil's inability to see the layman completes the process of detachment that began with the breaking of the chains. Beyond signaling the man's break from sin, however, the devil's faulty vision also points to the seamlessness of the layman's reincorporation into the penitential community of the parish. No longer marred by sin, he blends in with the rest of the crowd, one "among many," as the befuddled devil complains. ${ }^{61}$ The story of his spiritual reform is also powerfully articulated in and through physical space and through the series of increasingly repellant thresholds that weaken the bond between man and devil. Earlier in the handbook's section on penance, when Mannyng discusses the general benefits of confession, he explains that "shryfte ys pe zate of heuene," the metaphorical "wey" that "ledep" its penitents to salvation; those who confess are rewarded with access, while those who fail to repent "gete noun entre." ${ }^{\text {" }}$ Mannyng applies this theme of access and exclusion directly to the terrain of the parish in the exemplum by setting up an opposition of literal and metaphorical gates. The devil can enter the literal gate of the churchyard, but he is barred from entering the church proper and, subsequently, the metaphorical gate of heaven.

Parochial space itself proves compelling, a point that Mannyng underscores with a series of prepositional phrases. As we discover at the end of

6o. On the physiognomic skill required of priests, see Somerset, "Training the 'Lewed' Gaze," 319. Ford discusses "the visible nature of sin" in "Autonomy of Conscience," 16-17.

61. Mannyng, Handlyng Synne, line 12221.

62. Ibid., lines 12147-52. 
the story, the former sinner claims retrospectively to have felt the urge to confess his sins while making his way "to the church." Mannyng adds further emphasis by breaking up the syntax in order to put the prepositional phrase first: "To pe cherche as y wente my weye, / Y felt me charged yn a synne." "Y3 poghte y wlde me per of shryue," he decides, "and amende pe trespas in my lyue." ${ }^{64} \mathrm{He}$ makes a full confession "at pe cherche" - the phrase front-loaded once again. ${ }^{65}$ Having gravitated toward it while heavy with sin, he leaves the building feeling as though a burden has been lifted from his shoulders: "Me pynkp y am wndyrly lyght," he observes, newly unchained from the devil. ${ }^{66}$ The church at the story's gravitational center stands in for the act of confession itself, an event that takes place unseen behind its closed doors. Mannyng focuses instead on its violent repulsion of the devil on the one hand, and, on the other, its magnetic pull for a layman who feels the need to confess.

Although it centers on the performance of parochial confession, Mannyng's exemplum opens with a lengthy portrait of its narrator, the hermit stationed in the churchyard. "Pyr was ones an ermyte," he begins,

Pat was eure yn Gode parfyte.

So moche he had of goddes grace

Pat he coude knowe yn eury place,

Whyche men were yn dedly synne,

And who was gode lyff wyp ynne.

And also he myghte se wele

pyng pat was spyrytuele.

An haly day fyl as ys pe acyse,

Men to go to goddes seruyse;

Pys Ermyte lenede hym on a wal

And bad hys bedes \& loked oueral,

And byhelde be folk pat come in pe gate,

Whyche come erly \& whyche late,

Whyche come for gode deuocyun,

And whyche for ouper enchesun:

Al sagh pys Ermyte eurydeyl,

who com wrong \& who come weyl. ${ }^{67}$

63. Ibid., lines 12238-39.

64. Ibid., lines 12241-42.

65. Ibid., line 12243 .

66. Ibid., line 12246 .

67. Ibid., lines 12171-88. 
There once was a hermit, perfect in God and so endowed with His grace that he knew, in every place, which men were in a state of sin and who was leading a good life. He could also see spiritual things. A holiday fell when, according to custom, men go to Mass. This hermit leaned against a wall, bidding his beads and looking everything over. He watched the people entering the gate-who came early and who came late, who came out of devotion and who came for other reasons. He saw it all: those who came in the wrong, and those who came virtuously.

Mannyng draws particular attention to the hermit's watchfulness—he "loked" everything over, "beheld" it, "sagh" it all. The man's abilities invite comparison with the priest who reads sins on his parishioners' color-coded faces; he can see spiritual things and "know[s]" whether the parishioners entering the church are sinful or good. Indeed, when the hermit first appears, bidding his beads, he is leaning on the churchyard wall, a perch that affords him a good view of the parishioners as they come and go.

The story's prologue perhaps suggests to readers that this exemplum will concentrate on a skillful, all-seeing hermit whose abilities rival those of a priest. But instead, this spatially charged exemplum about the efficacy of parochial confession is conveniently narrated from the perspective of a liminal bystander whose churchyard location makes him well suited to report on the layman's condition as he exits the church. As a seer of "spiritual things," one of his virtues as a narrator is that he enables the reader to join him in the process. We too observe the layman's spiritual transformation as he enters and exits the church, and the hermit ultimately allows us to hear about it from the layman's own perspective. As the man exits the church, the hermit runs after him and, catching up, asks him to recount his experience: "Pys Ermyte [. . .] preyde hym a stownde to dwelle / And of hys lyff sumwhat to telle." ${ }^{68}$ The layman then recalls having long felt "charged yn synne" and subsequently feeling "w[o]ndyrly lyght." ${ }^{69}$ Importantly, the layman's account never amounts to an actual confession; we learn nothing about the sin that chained him to the devil. Instead, the layman's words offer a more general confirmation of the success of the confession he made, on the other side of the church doors, to his parish priest. I felt weighed down by sin, he claims, so I confessed, and now I feel better.

In calling his narrator a hermit, Mannyng makes a suggestive departure from his source text. In the Manuel des Péchés, the figure stationed in the

68. Ibid., lines 12233-36.

69. Ibid., lines 12239, 12246. 
churchyard is described as a holy man (un seint home).$^{70}$ In the lesser-known Middle English prose translation of the Manuel, whose anonymous translator was apparently unaware of Mannyng's verse translation, the "seint home" is translated as "holy man." ${ }^{\text {71 }}$ Although he uses the hermit's work to reinforce the efficacy of parochial confession, Mannyng's decision to call the man a hermit rather than a more generic holy man adds a layer of ambivalence by tapping into an ongoing contemporary debate about hermits and their questionable and potentially illegitimate profession. ${ }^{72}$ In addition to introducing such a loaded term, Mannyng is also vague about the hermit's location in respect to the churchyard. In the Manuel des Péchés, the holy man leans (se apoua) on the churchyard wall from the outside (outre le mur). ${ }^{73}$ But in Mannyng's version, it is unclear whether the hermit is in or out: "Pys Ermyte lenede hym on a wal / And bad hys bedes," he writes, glossing over the detail of where the man's feet are planted. ${ }^{74}$ This admittedly minor detail nevertheless suggests a level of beneficial churchyard porosity. We might even see the leaning hermit as an extension of the churchyard wall and its efforts to repel the devil by instilling him with fear and breaking the chains he uses to attach himself to laypeople. Indeed, after he hears from the newly confessed layman, the hermit approaches the devil and tells him to go back to hell. ${ }^{75}$ If Mannyng's churchyard is porous, its admission of a hermit would seem to bolster security against the devil while also reinforcing the primacy of parochial confession.

The story concludes with two interpretive voices but gives Mannyng himself the final word. Having interviewed the reformed layman, the hermit concludes that a person can free himself from the devil just by feeling a desire

70. "Un seint home iadis esteit / Qe tiel entendement aueit / Receu grace de Deu out, / Car sauer poeit, quant qe il vout, / Quant vn home ot auisé, / Si il esteit en peché." Waddington, Manuel des Péchés, 379-8o (lines 8951-56).

71. Of Shrifte and Penance, 119 (lines 28, 37).

72. Although ambivalence toward hermits was widespread, Hanna and Jones have argued that an emergent form of late medieval eremitism legitimized hermits' social interactions with laypeople, from preaching and hearing confessions to (in the famous example of Margery Kempe) chaperoning laypeople on pilgrimage. See Hanna, "Meddling with Makings," 74-76; idem, "Will's Work," 31-32, 40-41. In post-plague labor statutes, hermits were seen as doing spiritual "work" that benefited the larger Christian community, and because that work was not for profit, hermits could beg for sustenance without being criticized. Scase, "Piers Plowman" and the New Anticlericalism, 125, 136. Jones reports that royal letters of protection that enabled hermits to solicit alms, either in churches or on the road while traveling, were granted in increasingly high numbers in the first half of the fourteenth century. "Langland and Hermits," 74-75.

73. Waddington, Manuel des Péchés, 380 (line 8963).

74. Mannyng, Handlyng Synne, lines 12181-82.

75. The hermit "come pan to pe deuel / And bad he shuld do no man euel, / But go to helle, pere he come fro." Ibid., lines 12255-57. 
to confess. A man who takes "delyt" in sin is an easy target for the devil, whereas when a sinful person "hap wyl hym to shryue," the hermit resolves, "hys bands breste."76 Simply wanting to confess one's sins is powerful enough to break the devil's hold. Only once the sinner is cleanly confessed, however, does he become unknowable to the devil: "Whan he ys clene shryuen, / pe deuel knowep hym no more sypen." ${ }^{77}$ The story's central act of penance takes place, of course, behind the closed doors of the parish church, and as Mannyng makes clear when he steps in for the exemplum's closing couplet, the story is designed to draw listeners to church. In a final exhortation, he urges sinners to "bygynne" the process of confession, a process that he closely associates with parish priests. ${ }^{78}$ There is no need to mention the parish church at the end of this spatially charged tale because Mannyng assumes his listeners are already there in the nave and in the presence of the only priest who can truly absolve them of their sins.

\section{"Open the door to him that knocks"79}

But the porosity of the parish could also be a source of tremendous anxiety. Mannyng's exemplum stands in stark contrast to the antifraternal tradition and its outright condemnation of extraparochial figures and their invasion of the church. In Piers Plowman, for example, instead of benevolent hermits devoted to shoring up the churchyard and celebrating the virtues of parochial penance, we are more likely to find dishonest and duplicitous interlopers who worm their way in by whatever means necessary. At the end of his poem, Langland famously deploys the traditional antifraternal image of the domestic intruder: a friar named Penetrans Domos-so called in reference to a passage about "those who make their way into households" in 2 Timothyarrives at the Barn of Unity to "plaster" Conscience with an easy absolution. While Mannyng's hermit ultimately reinforces the boundaries of the parish and bolsters the sacrament of penance, Langland's friar exposes the acute vulnerability of both by insinuating himself into the church and attacking it from within. When called in as a confessor to Conscience, Penetrans Domos is

76. Ibid., lines 12248, 12251-52.

77. Ibid., lines $12253-54$.

78. Ibid., line 12259.

79. From the Sarum Rite for Baptism: "Receive him, Lord: and because thou hast vouchsafed to say, Ask and ye shall receive, seek and ye shall find, knock and it shall be opened unto you, grant a reward to him that asks, and open the door to him that knocks, so that having obtained the eternal blessing of the heavenly washing, he may receive the promised kingdom of thy bounty." Fisher, Christian Initiation, 161. 
described as a "leche," a "surgien," and a gentle plasterer, ${ }^{80}$ making him eerily similar to the ideal parish priest of canon 21, who, "like a skilled doctor," heals the "wounds of the injured." Because plastren can refer to the application of a plaster or poultice to a bodily wound, it certainly evokes the traditional motif of the doctorly priest. ${ }^{82}$ But Penetrans Domos' medicinal skills prove entirely superficial, offering no more than a quick band-aid solution to the problem of sin. The scene abounds with language related to concealment and disguise. When Penetrans Domos appears at the gate with a license to hear confessions, for example, Pees the Porter asks him to identify himself, or rather, not to conceal his identity: "I praye thee, hele noght thi name," he says. ${ }^{83}$ Langland brings together two very different verbs; helen can mean to cure or to heal but also to hide or to conceal. ${ }^{84}$ Although the friar claims to have come "for profit and for helthe" - that is, to provide healing-he ultimately fulfils the word's more negative and deceptive meaning. ${ }^{85}$ Even worse, while a full confession should reveal sins, Penetrans Domos' approach involves concealing sin and covering it up. The verb helen appears again inside the Barn, when Conscience asks Penetrans Domos whether or not he can "heele sike" before telling him to "conforte" Contrition and "take kepe to his soores." Ultimately, as we learn in the last ten lines of the passus, the friar heals by obscuring: he "enchaunt[s]" his patient with flattery and "phisyk" until Contrition forgets to feel contrite. ${ }^{87}$ Penetrans Domos destroys penance by annihilating one of its main components. In doing so, he derails the very mechanism through which the church constituted and perpetuated itself.

Although Penetrans Domos' work as a plasterer evokes the medical motif, it also gestures to the plastering of walls, a connotation that works to reinforce his association with physical violation. ${ }^{88}$ True to his name, the break-in

8o. Langland, Piers Plowman: A Critical Edition of the B-Text Based on Trinity College Cambridge MS B.15.17, ed. Schmidt, 20.305, 310-11. Unless otherwise indicated, all Piers quotations are taken from this edition of the B-text, hereafter referred to as Langland, Piers Plowman.

81. "The priest shall be discerning and prudent, so that like a skilled doctor he may pour wine and oil over the wounds of the injured one." Decrees of the Ecumenical Councils, 245. For a discussion of this passage in relation to "the 'proprius sacerdos' question," see Scase, "Piers Plowman" and the New Anticlericalism, 35.

82. MED, "plastren," 1a: "To cover (a sore, part of the body) with a plaster, poultice, or ointment; ben plastred, be covered with a plaster; also, be healed or cured."

83. Langland, Piers Plowman, 20.340.

84. $M E D$, "helen," v. 1, 1a: "to cure, heal; c. to apply treatment to." Cf. $M E D$, "helen," v. 2, 1a: "to cover; 2a: to conceal, hide; b. to shelter, protect; c. to be silent, keep a secret."

85. Langland, Piers Plowman, 20.333.

86. Ibid., 20.357, 359.

87. Ibid., 20.379.

88. MED, "plastren," 3a: “To plaster (a wall, etc.); besmear, bedaub, or overlay (sth.) with an adhesive substance." 
of Penetrans Domos involves a series of parochial violations, both spatial and liturgical. The Barn of Unity had been billed as a fortress against the friars, but it only takes a knock at the gate for one to gain entrance, a knock that recalls both the liturgy of Palm Sunday and the ceremony for the dedication of a church, both of which involved perambulatory processions that ended with a knocking at the door. ${ }^{89}$ It also echoes the Rite for Baptism, in which the priest, describing the relationship between baptism and salvific potential, reminds the catechumen and the broader congregation that, should a baptized Christian knock on the door, "it shall be opened" for him or her..$^{\circ}$ In contrast to these ceremonies, which celebrate the very making of the parish, the knock of Penetrans Domos signals its physical vulnerability.

As many scholars have observed, the Penetrans Domos scene satirizes the advent of the friars and the threat that their presence posed to the parish and its practices. The friars had been granted pastoral privileges-preaching, hearing confessions, and burying the dead-that had traditionally been reserved for the secular clergy, and, beginning in the middle of the thirteenth century, these privileges were the subject of intense debate in England and on the continent..$^{91}$ In part because they were so new, the friars were seen as fundamentally extrinsic to the institution of the church, and their critics had to look no further than the Bible for proof of the friars' illegitimacy: they were sweet-talking thieves and house breakers, idle ne'er-do-wells. ${ }^{92}$ The friars

89. For a description of the Dedication ceremony, see Bowen, "Tropology of Mediaeval Dedication Rites," 469-79. Cf. Ps. 23:7 (NRSV 24:9), "Lift up your heads, O gates! And be lifted up, O ancient doors! that the King of glory may come in." Margery Kempe recalls a Palm Sunday procession in which "the preyste toke the crosse-staf and smet on the chirche-dor, and the dor openyd ageyn hym, and than the preyst entryd with the sacrament and al the pepil folwyng into chirche." Book of Margery Kempe, 339 (lines 6262-65). See also passus 18 of Piers Plowman, in which Christ orders Lucifer and his followers to unlock the doors-to "unpynneth and unlouketh" - at the Harrowing. Langland, Piers Plowman, 18.263.

90. Fisher, Christian Initiation, 161. See also Matt. 7:7 and Luke 11:9 ("Ask, and it will be given you; search, and you will find; knock, and the door will be opened for you").

91. In 1300, Pope Boniface VIII issued a bull (Super Cathedram) that was intended to improve relations between mendicants and parish priests by regulating activities related to preaching, confession, and burial. Szittya, Antifraternal Tradition, 125; Scase, "Piers Plowman" and the New Anticlericalism, 20-22; Williams, "Relations between the Mendicant Friars and the Secular Clergy," 23-25.

92. The phrase penetrans domos comes from 2 Tim. 3:6: "For among them are those who make their way into households" (ex his enim sunt qui penetrant domos). Discussions of the friars' idleness often reference 2 Thess. 3:6 as well, in which Paul urges his reader to "keep away from believers who are living in idleness and not according to the tradition that they received from us." Paul also warns against those who "cause dissensions and offenses" with their "smooth talk and flattery" in Rom. 16:17-18. For further discussion of the penetrans domos motif and its biblical sources, see Scase, "Piers Plowman" and the New Anticlericalism, 15-16; Szittya, Antifraternal Tradition, 57-61. 
were suspiciously new, strange, and, to borrow a phrase from Kathryn KerbyFulton, "dangerously footloose." 93 They were also growing in number, and their ubiquity was widely lampooned..$^{94}$

\section{Grafting onto the Parish}

The administration of confession was at the heart of late medieval antifraternalism, in part because the friars' arrival postdated the Fourth Lateran Council of 1215 and its requirement of annual confession before one's own parish priest. In an effort to maintain parochial control over the sacrament of penance, English diocesans repeatedly argued that confession before a friar did not satisfy the obligation as mandated in canon $21 .{ }^{95}$ Archbishop Richard FitzRalph, whom Szittya has called "the most notorious opponent of the friars in the fourteenth century," ${ }^{\prime 96}$ emphasized this very problem in his Defensio Curatorum, a Latin proposicio that he delivered before the papal court at Avignon in $1357 .{ }^{97}$ The Defensio, translated by Trevisa between 1387 and $1398,{ }^{98}$ covers material that FitzRalph treated in a series of influential vernacular sermons at St. Paul's Cross in London. ${ }^{99}$ FitzRalph maintained that "for parischons of eny chirch to schryue hem wip exclusion of oper places, pe parische chirche is more worpi to be chosen pan oratory [a private chapel] oper chirche of freres." ${ }^{100}$ Not only was the parish the worthiest location for confession but the parish priest was a worthier listener than a friar. ${ }^{101}$ Parish priests make better

93. Kerby-Fulton, Reformist Apocalypticism, 136.

94. One of the most memorable examples appears in the prologue to the Summoner's Tale, in which the Summoner tells the story of the throng of friars swarming out from under the devil's tail: "Right so as bees out swarmen from an hive, / Out of the develes ers ther gonne drive / Twenty thousand freres on a route, / And thurghout helle swarmeden aboute, / And comen again as faste as they may gon / And in his ers they crepten everychon." Chaucer, Canterbury Tales, fragment 3 , lines 1693-97.

95. Williams, "Relations between the Mendicant Friars and the Secular Clergy," 25; Haren, "Friars as Confessors," 503-16.

96. Szittya, Antifraternal Tradition, 123.

97. See especially Walsh, "Archbishop FitzRalph and the Friars," 223-45; idem, FourteenthCentury Scholar, 413-14, 422-26.

98. Dolan, "English and Latin Versions of FitzRalph's Sermons," 34-35.

99. Dolan explains that "no English versions of any of these sermons (or indeed any of FitzRalph's works) survives, presumably because he worked from Latin notes or drafts." Ibid., 28. Horner discusses the importance of St. Paul's Cross and the sermons preached there in "Preachers at Paul's Cross," 261-82.

100. FitzRalph, Defensio Curatorum, 40 (lines 10-13).

101. "For parischons of eny chirche to schryue hem onlich to oon persone, pe ordenarye person is more worpi to be chosen pan eny freres persone." Ibid., 40 (lines 14-16). 
confessors, FitzRalph contends, because they are "bounde" to their parishioners and have their best interests in mind; a parish priest is motivated by love and can therefore offer more "profitable medicyn" than "eny friar, pat is a straunge person." ${ }^{102}$ Although FitzRalph is known for his vitriol against the friars, ${ }^{103}$ he was not alone in taking issue with their strangeness and their penchant for wandering. As far as their critics were concerned, the friars did not belong in the parish, nor did they have any business involving themselves in the administration of confession; they were, quite simply "bastard branches," and they needed to be pruned. ${ }^{104}$ This particular formulation appears in two different Wycliffite tracts from the late fourteenth century, and it draws attention to the friars' foreignness by comparing them to grafts or scions from other, unrelated trees. The image revisits a passage from Isaiah in which the "oaks of righteousness" are described as "the planting of the Lord." 105 The friars were, by contrast, "spronge in wipout auctorite of God," 106 or "cropun in by po fende." ${ }^{107}$

The metaphor of grafting was especially useful for the authors of antifraternal literature because it offered a dramatic illustration of the friars' illegitimacy. As a horticultural process, grafting involved uniting a cutting from a plant or a tree with a foreign stem or trunk, ${ }^{108}$ and instructional texts on the practice were widely available in both Latin and English. ${ }^{109}$ Gardeners used grafting to produce sweeter, longer-lasting fruit, but they could also use it to more artificial ends, coaxing plants and trees into yielding "frutes without cores," or "diuerse frutes in oon stok," as Nicholas Bollard's Book of Planting and Grafting (c. 1300-1350) instructs. ${ }^{110}$ Another contemporary horticultural

102. Ibid., 52 (lines 10-21).

103. Szittya has suggested that FitzRalph's preoccupation with the friars may stem from the poor state of affairs in his own diocese. Antifraternal Tradition, 124-25.

104. Selected English Works of John Wyclif, 3:239, 417. In Jack Upland, friars are chastised for being "unkynde as bastard braunchis." Six Ecclesiastical Satires, 200. See also Barr's discussion of this motif in Socioliterary Practice, 139-40.

105. Isa. 61:3.

106. Selected English Works of John Wyclif, 3:417.

107. Ibid., 3:239.

108. MED, "graffen," "to graft (a cutting or scion on a stock), insert; make a graft on (a tree); graft a cutting of (a tree) onto a stock." $M E D$, "impe," 1a: "a branch of a tree; a shoot, sprig." 1 b: "a scion, a graft." MED, "imping(e)," “a) a plant, shoot; esp. one newly set out or transplanted; b) a twig or shoot ready to be grafted on another plant, a scion; also, the action of grafting." Only in the nineteenth century does the verb begin to connote a dishonest financial practice (OED, "graft," 5).

109. Braekman, "Bollard's Middle English Book of Planting and Grafting," 19-39; Cylkowski, "Middle English Treatise on Horticulture," 301-29; Reinert, "Middle English Text on Planting," 9-16.

110. Braekman, "Bollard's Middle English Book," 32-33. 
guide teaches readers how to "make cherijs growe withoutyn stonys."111 The modificatory potential of grafting made it a useful metaphor for exploring unnatural pairings and conjunctions. Shakespeare often uses the metaphor to register social change and "the mixing of classes," as Rebecca Bushnell observes, "whether the bastard scion is being grafted on royal stock or a better plant on a wild one." 112

In fourteenth-century literature, grafting offers a forceful way of exposing the friars and their destructive meddling in the parish. Langland in particular exploits the metaphor's richness. In passus 20, Penetrans Domos' abuse of the sacrament of penance goes hand in hand with his physical violation of the church through breaking and entering. At other stages in the poem, and in a subtler interpretation of Timothy's warning about house-penetrators, Langland represents the friars as an invasive species that creeps its way into parochial space. In the confession of the Seven Deadly Sins in passus 5, for example, Wrath is figured as a friar who happens also to have been employed as a gardener in his convent. His confession chronicles the damaging longterm effects of his grafting:

"I am Wrathe," quod he, "I was som tyme a frere,

And the coventes [friary's] gardyner for to graffen impes.

On lymitours and listres lesynges I ymped [on mendicants and lectors I grafted lies],

Til thei beere leves of lowe speche, lordes to plese,

And sithen thei blosmede abrood in boure [bedrooms] to here shriftes.

And now is fallen thereof a fruyt-that folk han wel levere

Shewen hire shriftes to hem than shryve hem to hir persons [parsons, parish priests].

And now persons han parceyved that freres parte with hem,

Thise possessioners preche and deprave freres;

And freres fyndeth hem in defaute, as folk bereth witnesse,

That whan thei preche the peple in many places aboute,

I, Wrathe, walke with hem and wisse [teach] hem of my bokes."13

Grafting has enabled Wrath to engineer a new, more mendacious kind of friar who lures laypeople away from parochial confession. First, Wrath grafts lies ("lesynges") onto mendicant and preaching friars, and the earliest shoots of flattery and deference-the pleasing "leves of lowe speche"-soon blossom

111. Cylkowski, "Middle English Treatise on Horticulture," 313.

112. Bushnell, Green Desire, $148-49$.

113. Langland, Piers Plowman, 5.135-46. 
in the form of extraparochial confessions that take place "abrood in boure," a detail that intensifies the illicit nature of off-campus confession by sexualizing it. The graft yields abundant fruit: parishioners would rather confess to a friar than a parson. As Wendy Scase has shown, the ultimate end product of Wrath's horticultural tinkering is a "longstanding" conflict between parish priests and the friars over pastoral privileges, including the right to hear confessions. ${ }^{114}$ In addition to propagating fraternal mendacity, Wrath has developed a new, more vituperative priest who devotes his sermons to the vilification of the friars.

Langland also links grafting with the friars in his representation of Antichrist, an evil gardener by trade who also serves as clothier to the friars:

Antecrist cam thanne, and al the crop of truthe

Torned it tid [quickly] up-so-doun, and overtilte [upturned] the roote,

And made fals sprynge and sprede and spede mennes nedes.

In ech a contree ther he cam he kutte awey truthe,

And gerte [made] gile growe there as he a god weere.

Freres folwede that fend, for he gaf hem copes,

And religiouse reverenced hym and rongen hir belles,

And al the covent [convent] cam to welcome a tyraunt. ${ }^{115}$

Undoing the truth-tilling labor of Piers, Antichrist rips truth out at the roots and propagates guile and falsehood in its place. Antichrist's horticultural work flows seamlessly into his role as clothier. Indeed, we might even think of Antichrist as a gardener whose crops include not only "fals" and "gile" but a bountiful swarm of cope-wearing friars.

Horticultural imagery illustrated the ubiquitous and invasive nature of the friars. It also helped to show the extent to which the parish, now encumbered by friars, had begun to suffer; as the friars grew more robust through grafting, the parish was thinning out. As one antifraternal text puts it, "sith pei comen in has po chirche payred in everiche member."116 Payren extends the horticultural metaphor. The verb often refers to the kind of thinning and cutting back that a farmer or gardener does, but here it describes the thinning of its lay membership as a consequence of the friars' invasive presence. ${ }^{117}$ While friars were often imagined as unwanted grafts that had overgrown the

114. See Scase's discussion of this passage in "Piers Plowman" and the New Anticlericalism, $17-23$ (at 18 ).

115. Langland, Piers Plowman, 20.53-60.

116. Selected English Works of John Wyclif, 3:418.

117. MED, "paren," v.1, 1a. 
parish, laypeople themselves were being figured as scions that had been cut away from the parish and rerooted in friaries. This reverse form of grafting could take any number of forms. Laypeople might seek out friars as confessors or, for a more permanent form of transplant, they could, in addition to commissioning postmortem prayers, pay to have their bodies buried at friaries. Perhaps not surprisingly, a favorite motif in antifraternal literature is the vulturine corpse-chaser looking to profit from burial fees. ${ }^{118}$ Burial was just one of many ways for laypeople to interpolate themselves into the space and fabric of a friary; they could also make their mark by donating to building campaigns or glazing stained-glass windows.

\section{Meed and the Problem of the Parish}

In passus three of Piers Plowman, Langland exposes the unnaturalness of these forms of lay self-inscription by associating them with grafting. In exchange for easy absolution, a female figure named Meed (or "reward") becomes a major benefactor to a friary, supporting not only a significant construction campaign but also "graving" her name in a stained-glass window that broadcasts her generosity. Although the encounter between Meed and the friar begins with an ostensibly spiritual transaction, it quickly becomes a scene of protracted financial haggling and ante-raising. First, in exchange for a "seem of whete," the friar offers to serve as her "bedeman" and put a good word in for her among people who matter, "to bere wel [her] erende / Amonges knyghtes and clerkes." ${ }^{\prime \prime 9}$ The spiritual and the financial go hand in hand: not only does Meed make a bogus confession while handing over a coin, but the friar immediately absolves her and, in the same breath, asks her to glaze a window. We have a window in the works, he says; "Woldestow glaze that gable and grave there thy name, / Sykir sholde thi soule be hevene to have." 120 The bargaining continues as Meed agrees to repair the roof, build a cloister, whitewash the walls, and commission a donor portrait, all in exchange for the friar's gentle treatment of lechers. "Have mercy," she says, "of men that [lechery] haunteth,"

118. Richard FitzRalph describes the friars as vultures keeping an eye out for wealthy corpses: "Pei rauyschip no pore dede mennes bodyes for to burie, but pei smellep her mete \& witep where hit is \& feccep hit fyve hundrid myle ouer pe see as vulturs dop." FitzRalph, Defensio Curatorum, 72 (lines 19-20). See also Pierce the Ploughman's Crede, in which the friars are figured as lying in wait to "catch" confessions and burials: "Thei coueten confessions to kachen some hire, / And sepultures also some wayten to cacchen." Piers Plowman Tradition, 80 (lines 468-69).

119. Langland, Piers Plowman, 3.40-42.

120. Ibid., 3.49-50. 
And I shal covere youre kirk, youre cloistre do maken,

Wowes [walls] do whiten and wyndowes glazen,

Do peynten and portraye who paied for the makynge,

That every segge [person] shall see I am suster of youre house. ${ }^{121}$

The scene emphasizes the explicitly financial and decidedly nonspiritual nature of Meed's relationship with the friars. ${ }^{122}$ But it also chronicles Meed's aggressive pursuit of every possible surface for purposes of self-promotion and self-inscription. Her emphasis on the friars' possession of the building, its walls, and its windows- "youre kirk," "youre cloistre," "youre house"ultimately points to her own foreignness. Her desire for others to "see I am suster of youre house" only reinforces the problematic fact that her presence there is unnatural, that the basis of her sisterhood is financial rather than familial or spiritual. Meed is not a legitimate sister but an artificial transplant, a nonnative scion. Indeed, the horticultural metaphor comes to mind when the friar invites Meed to "grave" her name in a window because graven can refer both to burial and cultivation ${ }^{123}$ and because the words grave and graven are sometimes spelled graffe and graffen. ${ }^{124}$ Beyond suggesting a window engraving, then, the friar effectively invites Meed to graft herself onto the friary through self-inscription.

Meed is also grafted by way of the grave, at least in two early copies of the poem. When the friar offers to absolve Meed, he also promises that he will "be [her] bedeman, and bere wel [her] erende / Amonges knyghtes and clerkes, Conscience to torne." ${ }^{125}$ In two fifteenth-century manuscripts of Piers Plowman, the noun erende, which means message, has been miscopied as erdyn, which means burial place. ${ }^{126}$ What Schmidt has recently dismissed as a "backspelled" and "pointless synonym substitute" substantially alters the meaning of the line by introducing the practice of friary burial. ${ }^{127}$ Instead of offering to "bere wel" her message (her erende) among knights and clerks, the friar imag-

\footnotetext{
121. Ibid., 3.59-63.

122. See especially Lawler's recent discussion of the Meed episode in "Harlots' Holiness," 150-51; Wood discusses the problem of the friars in relation to Meed in Conscience and the Composition of "Piers Plowman," 87-106.

123. MED "graven," 1a: "to bury"; 2a: "to dig," "to cultivate."

124. For these spelling variants, see the MED entries for "grave" (n. 1) and "graven" (v.1).

125. Langland, Piers Plowman, 3.41-42.

126. MED, "erden," 4: "to bury (a corpse)." MED, "erding, -ung," n., c: "burial place." "Erdyn" appears in the H manuscript of the B-text (London, British Museum, Harley 3954). Piers Plowman: The B Version, ed. Kane and Donaldson, 273, n. 41. The J manuscript of the A-text (Ingilby MS, Pierpont Morgan Library of New York, M 818) contains “erdene." Langland, Piers Plowman: The A Version, ed. Kane, 229, n. 40.
}

127. Langland, Piers Plowman, 367, n. 41. 
ined in this alternative reading offers to "bere wel" her burial (her erdyn). In addition to inviting Meed to engrave her name in glass, the friars encourage her to reject the parish outright through friary burial.

The grafting metaphor perhaps also extends to the friar's offer to become Meed's "bedeman," a term that refers to his involvement in a conspicuous and lucrative prayer industry while also gesturing toward the bede-roll, the list of living and dead benefactors that was read regularly in the parish in order to commemorate those who had given monetary gifts or bequests of particular items. ${ }^{128}$ In some parishes, the bede-roll provided a source of revenue used at the discretion of the laity for the maintenance of the church and its fabric; in others, proceeds from the bede-roll were considered part of the priest's salary or benefice. Because it immortalized generations of benefactors, the bede-roll was not only itself a cherished item of church fabric but also a historical artifact that fostered a tangible relationship between the living and dead members of a particular parish. In this respect, the bede-roll provided what Duffy has called a "social map of the community" that promised each benefactor "a continuing place in the consciousness of the parish in which he or she had once lived, not as one of the anonymous multitude of the dead but as [a] named provider." ${ }^{129}$ Langland criticizes the friars for usurping pastoral privileges such as hearing confessions and burying the dead, but he also exposes their manipulation of a lay tradition that played an important role in constructing the parish and its spiritual network. The friar lures Meed away from parochial commemorative practices by encouraging her to seek out the prayers of friars rather than those of her parish priest or her fellow parishioners. Although Langland elsewhere uses the metaphor of grafting to explore the friars' invasion of the church, in the Meed episode he draws particular attention to the attrition of laypeople from it. Meed grafts herself onto the space of the friary by painting its walls and engraving her name in its windows, and when she gives the friar "a noble / For to ben hire bedeman and hire brocour alse," she registers herself in its bede-roll. ${ }^{130}$

As part of a broader censuring of the friars, this scene exposes the problem of parishioner attrition and the disturbing dislocation of penance. When confession leaves the parish, it occasions financial bargaining, and the space

128. MED, "bede-man," 3a: "One who prays for another; esp., an almsman who prays for his benefactors, an inmate (of a religious foundation) whose duty is to pray for the founder and his heirs." Bedemen were ubiquitous enough to have been considered "a class of pensioner whose sole occupation was to remember the benefactor." Duffy, Stripping of the Altars, 328. On the parish bede-roll, see French, People of the Parish, 102; Gasquet, Parish Life in Mediaeval England, 222-25.

129. Duffy, Stripping of the Altars, 335.

130. Langland, Piers Plowman, 3.45-46. 
and fabric of the church no longer chart a layperson's progression from sin to salvation-or from churchyard gate to church door, as we saw in Handlyng Synne. Instead, walls and windows become vehicles for self-promotion. In Mannyng's exemplum, penance plays a central role in shaping the parish and welcoming a reformed sinner back into its fold: after confessing, the formerly shackled layman is "one among many," indistinguishable from his fellow parishioners. In Langland's Meed episode, however, confession ends not in reincorporation but in the exaltation of the individual who pays the most. Instead of generating a community of cleanly confessed penitents, extraparochial confession generates profit and notoriety, all publicly displayed on the walls and in the windows. 


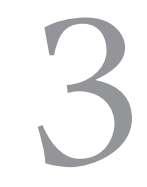

\section{The Parish on Its Feet}

\section{Lay Devotion and the Metaphor of Walking}

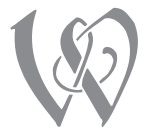

alking was one of the most defining features of parochial worship. Processions were a regular occurrence in the ritual life of the parish, an important expression not only of the layperson's step-by-step progression toward God but of the broader parochial ideal of walking together in charity. Processional movement was part of a much broader tradition of associating spiritual development-in particular, the cultivation of charity and the avoidance of sin-with walking and climbing. Augustine, for example, described love as the foot of the soul, and in Middle English sermons, devotional handbooks, and catechetical guides, walking and climbing measure a person's progress toward salvation. Whether by climbing a ladder of charity or by healing their rotten limbs through confession, laypeople were taught to correct and regulate their spiritual gait in this life. As I argue in this chapter, pedestrian movement was an important emblem of the layperson's lifelong pursuit of salvation.

Although it was conventional to think of earthly life as a pilgrimage, a kind of temporary stopover on the way to eternal life with God, the motif of spiritually efficacious walking engages a 
different set of aims. ${ }^{1}$ Pilgrimage - whether actual or imaginary, regional or international-prioritizes the traveler's final destination and figures the journey itself as the means to that more important end. ${ }^{2}$ Instead of prioritizing only the final goal, the motif of walking prizes the means to it. That is, the motif assigns special value to the layperson's efforts in this life to avoid sin and live charitably, efforts that are inherently difficult and which ultimately register as productive, hard-earned steps on the long road to salvation. In finding value in the mundane, "step-by-step" process of achieving salvation, the motif also recognizes the distinctly parochial nature of getting saved. ${ }^{3}$ Unlike pilgrimage, with its emphasis on a traveler's final destination, the metaphor of walking focuses attention on the layperson's work in the here and now and suggests that climbing one's way to heaven is a local endeavor, rooted in and facilitated by the collective ritual life of the parish.

\section{"Alle maner of peple be a-bowte to-geder": Parochial Procession and Passage ${ }^{4}$}

The liturgical year was studded with processions. A regular feature of the Sunday Mass, processions in more elaborate forms marked special days and seasons throughout the year, particularly Eastertide, Corpus Christi, and Candlemas. They were also part of the celebration of saints' feasts and church dedications, and the annual observance of Rogationtide involved a perambulation of the boundaries of the parish on three consecutive days. ${ }^{5}$

1. On the traditional association of earthly life with pilgrimage, see especially Wenzel, "Pilgrimage of Life as a Late Medieval Genre," 370-88.

2. Geary has suggested that pilgrims experienced pilgrimage as "a temporary hiatus in their normal lives." Living With the Dead, 163. Dyas offers a useful introduction to late medieval English pilgrims and their practices in Pilgrimage in Medieval English Literature, 128-44; see also the essays collected in Pilgrimage: The English Experience from Becket to Bunyan, particularly Morris's "Pilgrimage to Jerusalem in the Late Middle Ages” (141-63) and Duffy's discussion of regional pilgrimage in "Dynamics of Pilgrimage in Late Medieval England" (16477). Connolly explores the ways in which maps were designed to engage monastic viewers in active meditation, thereby enabling them to embark on spiritual or "imagined" pilgrimage in Maps of Matthew Paris, 28-39.

3. As Robert Banks observes in an essay on the metaphor of walking in biblical texts, the effort was construed as a "step-by-step affair, an ongoing, everyday process." "Walking' as a Metaphor," 309-10.

4. Speculum Sacerdotale, 139 (lines 20-21).

5. On medieval processions, see Flanigan, “The Moving Subject: Medieval Liturgical Processions," 35-51; Reynolds, "The Drama of Medieval Liturgical Processions," 127-42; Rubin, Corpus Christi, 243-71; Duffy, Stripping of the Altars, 15-22, 23-28, 136-39; Hutton, Stations of 
The author of the Speculum Sacerdotale, a Middle English sermon collection from about 1400, conceives of the liturgical year as a series of collective commemorative processions. "Pere bep made thre processiouns," the author writes in his sermon for Easter Sunday, "one that is made in the Purificacion of oure lady" and "another procession pat is made yche yere in the Sonday of Ramispalmarum." "Still other processions are made "yche Sonday," he explains, summing up the liturgical year.? The author's inventory of processions certainly reflects, at least in part, the late medieval penchant for liturgical instruction. Indeed, given the fact that sermons were "surrounded by liturgical actions," it is perhaps not surprising that sermon collections such as the Speculum Sacerdotale and Mirk's Festial provide detailed instruction on processions, encouraging listeners to make connections between biblical events and their liturgical commemoration and to find spiritual meaning more generally in church rituals and practices. ${ }^{8}$ Middle English sermons offer crucial evidence about the meaning and function of liturgical practices, especially the processions that shaped the liturgical year.

The Speculum-sermonist's conception of the liturgical year as a series of processions also acknowledges the important role that processional activity played in constructing the parish. He closes the sermon by observing that "the procession is made yche Sonday in representacion of that [which] the apostles made to oure lord in the day of his ascencion." The original event "ne was not made in the Sonday," he notes, but "it is now translatyd in-to the Sonday for pat pe procession mowe be solemply doon when the peple are togedre." This is a prime example of liturgical practice shaping the layperson's understanding and conception of biblical events, as Duffy has argued. ${ }^{10}$ But it also emphasizes the collective dimension of processions and suggests, moreover, that laypeople themselves have shaped the liturgy: in celebrating the apostles' Ascensiontide procession on Sundays, the contemporary practice prioritizes widespread participation on a day when the church is at its fullest. As a medium of worship, processions brought a parish together in what

the Sun, 182-97, 204-13, 277-87. Graves explores the relationship between liturgical processions and parochial space in "Social Space in the English Medieval Parish Church," 306-7.

6. Speculum Sacerdotale, 128 (lines 32-37).

7. Ibid., 129 (line 1).

8. Poleg, "A Ladder Set Up on Earth': The Bible in Medieval Sermons”, 207-8. Liturgical explication is common in Middle English sermon collections. See Powell's discussion of John Mirk's interest in helping his readers perform and, more importantly, understand liturgical rituals. Mirk, Festial, xxxviii. See also Weatherley's introduction to Speculum Sacerdotale, xxiv, xxxiii.

9. Speculum Sacerdotale, 129 (lines 1-7).

10. Duffy, Stripping of the Altars, 35 . 
Kathleen Ashley has called a "public statement" of their shared commitment to the church and to the pursuit of salvation. ${ }^{11}$

Parish communities were, of course, not as neat and harmonious as their orderly processions made them out to be. ${ }^{12}$ Instead of concentrating on whether or not processions fostered an ethos of solidarity, however, I want to suggest that vernacular sermons emphasize the collective nature of processions in the service of shaping the processing parish as a kind of working group, actively engaged in the ongoing struggle against sin. Processional activity offers not just a reflection of the parish, harmonious or not, but a representation of its participants' step-by-step movement toward salvation. The Palm Sunday procession, we might remember, chronicles the penitential progress of parishioners: those who had made an early confession were rewarded for their achievement with palms. ${ }^{13}$ The procession commemorates Christ's own entry into Jerusalem, but as Mirk explains in his Festial, it also celebrates the contemporary participants' own resurrection from the "deth of evel leuyng [living] to pe lyue [life] of grace." ${ }^{14}$ The palms signify not only that their individual carriers have "fowton wyth pe fende" but that the parish as a whole has triumphed, that "oure enemye" has been overcome. ${ }^{15}$ Rogation processions make an even more explicit demonstration of collective progress against sin and the devil. Performed on each of the three days preceding the Ascension, the procession required both clergy and congregants to trace the outer limits of the parish, a practice sometimes referred to as the "beating of the bounds." ${ }^{16}$ Representations of dragons-either on banners or in the form of more complex, mechanized puppets-were a standard feature of the three-day procession. On the first two days, a dragon banner or straw-stuffed

11. Ashley, "The Moving Subjects of Processional Performance," 15. On the Corpus Christi procession as an expression or embodiment of "social wholeness," see James, "Ritual, Drama, and Social Body," 9, 15-16. See also Sargent's recent description of a late medieval image of a parochial Corpus Christi procession in which a congregation walks the perimeter of a churchyard. The parish imagined here is, as Sargent notes, a "microcosm of the world," and its well-manicured churchyard, neatly enclosed by a wooden fence, reflects the unity of its idealized congregation as they process through it. Sargent, "Program of Illustration," 258, 266 (plate 6).

12. Rubin in particular warns against placing too much emphasis on the capacity of processions to create neat and tidy communities or "body-town[s]." See "Small Groups," 132-50, at 145. See also Beckwith, Signifying God, 24-31.

13. Speculum Sacerdotale, 98 (lines 16-17). For further discussion of Palm Sunday processions, see chapter 2.

14. Mirk, Festial, 101 (lines 22-23).

15. "Iche criston man and womman schal pis day beron palmus in processioun, schewing pat he hath fowton wyth pe fende, and hath pe victorye of hym bi clene schryuing of mowpe." Mirk, Festial, 102 (lines 53-57).

16. Duffy, Stripping of the Altars, 136. 
dragon would occupy a place of prominence at the head of the procession, in front of the cross. On the third day, the defeated dragon-signified by removing the stuffing from its tail or carrying the banner backwards-would be relegated to the foot of the procession as a symbol of the participants' shared victory over the devil. ${ }^{17}$

In emphasizing the success of the parish as a whole, sermonists underscore the importance of widespread participation in Rogation processions. "None schal excuson hym from peise processiones pat may godely ben per," writes Mirk; "Holy Chyrch ordeyneth vche man to faste pese pree dayes and to gon in processyoun." ${ }^{18}$ The author of the Speculum Sacerdotale explains that "worldly occupacionis" are to be left behind and that servants and bondmen should be excused from their work in order to attend the procession. "Alle maner of peple," he instructs, should be "a-bowte to-geder." ${ }^{19}$ Rogation processions played an important role in the formation and preservation of village and town identities, and as Steven Justice observes, they "made the community visible as a population - displayed the village to itself-while recalling and making visible the community as a locality, a place and a unit of production." ${ }^{20}$ As a public statement of parochial identity, the act of processing during Rogationtide also defined a parish by its collective effort against the devil; that is, these processions not only produced a parish, they produced a parish actively engaged in the battle against sin. Taking place over the course of three days, the series of three processions underscores the incremental nature of this battle-only on day three is the dragon defeated. Nor is the victory complete. The Speculum-sermonist explains that the threeday format represents the devil's long history as a troublemaker in three different ages: before Christ, during the life of Christ, and after Christ's death. Unfortunately, the devil remains on the prowl, even now: he "deceyued the peple" in each of these ages, the sermonist warns, "and zit is abowte for to deceyue hem.." In celebrating parishioners' triumph over sin and the

17. The Rogationtide sermon in the Speculum Sacerdotale describes a three-day procession in which a long-tailed dragon is carried before the cross for the first two days and behind the cross on the third (141 [lines 25-31]). For a Rogation procession involving both banners and a dragon, see the South English Legendary, 162 (lines 41-48). Mirk describes a procession with banners. Festial, 139 (lines 46-47). Vauchez discusses the Rogation procession and its history in Laity in the Middle Ages, 133-37. See also Duffy, Stripping of the Altars, 136-39.

18. Mirk, Festial, 138-39 (lines 6-7, 43-45).

19. Speculum Sacerdotale, 139 (lines 18-21).

20. Justice, Writing and Rebellion, 165 (author's emphasis). According to Fletcher, Rogation processions served an essential documentary purpose until the mid-nineteenth century, when the Ordnance survey began mapping England's parochial and administrative boundaries. "Parish Boundary," 182-84.

21. Speculum Sacerdotale, 141 (lines 30-31). 
devil, the Rogation procession also acknowledges that the fight against sin is ongoing. Indeed, the Speculum-sermonist explains that participants come together at Rogationtide "to haue foryeuenes and grace rizt as they alle togeder hadde synned." ${ }^{22}$ The procession ultimately celebrates their provisional defeat of the devil while gesturing to their shared status as penitents who must continue to work toward salvation.

On both Palm Sunday and during Rogation, the enactment of a procession symbolizes the spiritual triumph of a parish. In his sermon for Easter, Mirk draws special attention to processional movement- to "passyng," or passage-as a medium of spiritual development, a means of moving from sin to virtue and from earthly life to salvation. Mirk explores the etymology of pasche, the Latin word for Easter, in order to link the holiday with pedestrian movement. ${ }^{23}$ In "englys tonge," he writes, "Pashe Day" means "passying day," a fitting description, to Mirk's mind, because Easter "passes" all other days in terms of Christians' eagerness to come together in forgiveness, having been healed with the "salve of charity." ${ }^{24}$ Easter is also a passing day, Mirk explains, because the procession marks the very passage of its participants out of sin. As we know from Palm Sunday sermons, the Easter season itself celebrated Christians' early fulfillment of the sacrament of penance, and on Easter Sunday, those who had fully confessed their sins were eligible to take communion. And yet, while Christians may have satisfied their penitential obligations, at least for the time being, Mirk's Easter sermon emphasizes the ongoing nature of the fight against sin. Indeed, his explication of Easter enacts the very "passinge" that it celebrates. Instead of observing that his listeners have already passed from sin to virtue, he claims that they should. He then works his way through the seven deadly sins, one by one, pairing each with its opposing virtue:

Hit is also a passinge day, for vche criston man schulde passon owte of euel lyuing into gode lyuynge, owte of vices into vertues, owte of pryde into meknesse, owte of couetyse into largenesse [generosity], owte of sclowthe [sloth] into holynesse or bysines, owte of envye into loue and charite, owte of wrathe into mercy, owte of glotonrye into abstinens, owte of lecherye

22. Ibid., 139 (lines 21-22).

23. Mirk's discussion of pasche is heavily indebted to John Beleth's Summa de Ecclesiasticis Officiis, a twelfth-century commentary on church ritual: see Powell's discussion in her notes to Mirk's Festial, 352, n. 40-54; Macy, "Commentaries on the Mass during the Early Scholastic Period," 27-29. Mirk was not the only sermonist to take an interest in the etymology of Pasche; the author of the Speculum Sacerdotale, for example, explores its roots in the Greek and Hebrew words for "passing." Speculum Sacerdotale, 117 (lines 25-32).

24. Mirk, Festial, 115 (lines 40-41, 45). 
into chastite, owte of pe fendus clokus [clutches] into Goddus barme [arms], and so of Goddus enmy make hym hys dere frende and derlynge $\left[\right.$ darling.$^{25}$

Mirk presents the passage from vice to virtue as a series of incremental steps-from pride to meekness, from covetousness to largesse, and so onthat culminate in future salvation. Those who have completed the passage will trade "fendus clokus" for "Goddus barme" and, ultimately, God's friendship. "Whoso passus pus," Mirk explains, "is worthy for to cum to pat grete feste pat God makyth pis day to alle pat pis passage makyth." ${ }^{26}$ The ritual thus celebrates the participants' achievement of having avoided sin, but it also recognizes the step-by-step nature of passing from evil to good.

Although Mirk never mentions footsteps per se, pedestrian movement looms over the sermon, in part because the Easter liturgy featured an elaborate procession on foot but also because Mirk repeatedly folds the Latin word for step-passus - into his discussion of Eastertide passing and passage. The collective passage that Mirk's listeners undertake at Easter and throughout the liturgical year anticipates-perhaps even rehearses-their eventual passage to heaven. In observing that Christians achieve salvation by way of incremental passus, however, Mirk also activates a powerful trope used in sermon exempla, narrative poetry, and even visual imagery as a way of exploring the mechanics of getting saved.

\section{My Foot Is My Love}

Mirk's treatment of Eastertide passage is part of a long tradition of associating both charity and the avoidance of sin with pedestrian movement. The parochial ideal of charity (or caritas) had its roots in the Golden Rule, the injunction to love both God and neighbor. ${ }^{27}$ In the Lay Folks' Catechism (1357), the Middle English translation of Archbishop Thoresby's Latin Injunctions, charity is described as "a dere loue that us augh to haue / Unto god almighten and all our euen-cristen." ${ }^{28}$ Above all, charity concerned doing

25. Ibid., 115 (lines 45-52).

26. Ibid., 115-16 (lines 52-54).

27. "[Jesus] said to [the Pharisees], 'You shall love the Lord your God with all your heart, and with all your soul, and with all your mind.' This is the greatest and first commandment. And a second is like it: 'You shall love your neighbor as yourself.' On these two commandments hang all the law and the prophets" (Matt. 22:37-40). On charity and the "two loves," see Swanson, Religion and Devotion in Europe, 18-19.

28. Lay Folks' Catechism, 80 (lines 407-8). Swanson discusses the relationship between Thoresby's Latin Injunctions and the Middle English translation in "Origins of the Lay Folks' 
what one should-one "augh to haue" love not only for God but for one's fellow even-Cristen. As a spiritual imperative tied to the ideal of loving God and neighbor and to the principle of mutual help, charity permeated all aspects of lay social, civic, and spiritual life. ${ }^{29}$ The neighborly ideal went hand in hand with avoiding the socially destructive behavior associated with the Seven Deadly Sins, and Paul, in his First Letter to the Corinthians, defines charity in part by explaining what it is not: neither envious nor proud, for example. ${ }^{30}$ It was commonplace in medieval sermons, handbooks, and visual sources to juxtapose each of the seven vices with each of the seven virtues, and as a general antidote to all sins, Charity was often considered the highest virtue. ${ }^{31}$ The Mass itself was studded with references to charity, from the plea for mutual forgiveness at the end of the Pater Noster to the priest's request that parishioners receive the requisite "bond of peace and charity" in preparation for communion. ${ }^{32}$ Charity was also closely associated with the physical space of the church itself-the Dedication Rite, for example, includes a petition to God for help in providing the church and its parishioners with the "unbreakable bonds of charity."33

More than a means of avoiding sin, and more than what Thoresby described as a feeling that one ought to have toward others, charity was also

Catechism," 92-100. Fitzgibbons examines the translation and its more particular emphasis on lay learning in "Disruptive Simplicity: Gaytryge's Translation of Archbishop Thoresby's Injunctions," 39-58.

29. For a recent discussion of the "religious character" of charity, see Brodman, Charity and Religion in Medieval Europe, 9-44, at 2. See also Buhrer, "From Caritas to Charity," 113-28. The topic of mutual obligation has received much attention from social historians of the Early Modern period. See especially Brigden, "Religion and Social Obligation," 68; Wrightson, "Mutualities and Obligations," 157; Hindle, "A Sense of Place?" 108-9.

30. 1 Cor. 13:4-7: "Love [caritas, charity] is patient; love is kind; love is not envious or boastful or arrogant or rude. It does not insist on its own way; it is not irritable or resentful; it does not rejoice in wrongdoing, but rejoices in the truth. It bears all things, believes all things, hopes all things, endures all things."

31. "Charitye destroyep al maner synnus." Memoriale Credencium, 75 (lines 16-17). In his First Letter to the Corinthians, Paul describes charity as "the greatest" virtue, taking precedence over faith and hope (1 Cor. 13:13). On the vices and virtues in medieval art, see Katzenellenbogen, Allegories of the Virtues and Vices, 63-68; O'Reilly, Studies in the Iconography of the Virtues and Vices, 325-32.

32. "Habete vinculum pacis et caritatis ut apti sitis sacrosanctis mysteriis Dei," from the York Use, printed as an appendix to Lay Folks Mass Book, 114 (line 1). On charity as a prerequisite for communion, see especially Bossy, "Mass as a Social Institution," 29-61; Thiery, Polluting the Sacred, 78-81.

33. Thiery examines charity in relation to the liturgy of church dedication in ibid., 41-45 (quotation appears at 45). See also the Speculum Sacerdotale, in which the dedication sermon describes the church as the "habitacion of God, concourse of angels, [and the] reconsiliacion of man," a place within which "the lowenes of erpe" is "fellascipid to the hyenes of heuene" (163 [lines 34-36]). 
a call to action. Late medieval Christians looking for a more practical guide to charitable living - not just what to avoid but what to pursue-found it in the Corporal Works of Mercy, the outward expressions of charity outlined in Matthew 25 and treated in late medieval catechetical works such as Mirk's Instructions for Parish Priests. ${ }^{34}$ The seven Corporal Works were taught in sermons and during confession and comprised a set of obligatory charitable works that laypeople were expected to do on behalf of their "euen-cristen." 35 As a call to action, charity was often associated with motion and, more specifically, with walking, running, and climbing. The ambulatory theme is central to the biblical writings of Paul, who, on dozens of occasions, describes Christian life in peripatetic terms, urging his followers to "walk in love,"36 to walk worthily, ${ }^{37}$ and to walk in the Spirit ${ }^{38}$ and in Christ. ${ }^{39}$ Augustine forges a link between charity and movement in De Doctrina Christiana, where he describes caritas as "the motion of the soul towards the enjoyment of God." ${ }^{40}$ Charity is not just the motion of the soul, however, but the motion of feet: in his Commentaries on the Psalms, Augustine likens love to a foot that, when headed in the right direction, is called charity. ${ }^{41}$ While pride is associated with falling,

34. Matt. 25:34-36 prescribes the first six Corporal Works (feeding the hungry, giving drink to the thirsty, welcoming the stranger, clothing the naked, healing the sick, and visiting the prisoner), and the Book of Tobit (Tob. 1:16-17) provides the seventh (burying the dead). For further discussion, see Cullum, "Practice of the Spiritual and Bodily Works", 177-79.

35. Lay Folks' Catechism, 70 (line 350).

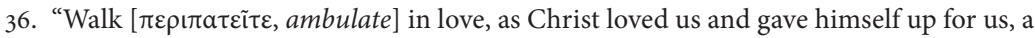
fragrant offering and sacrifice to God" (Eph. 5:2). Here and in the following three quotations, I have modified the NRSV (which offers "live" rather than "walk") to reflect Paul's use of the verb $\pi \varepsilon \rho \iota \pi \alpha \tau \varepsilon \tilde{\imath}$ (peripatein, to walk), rendered ambulare in the Vulgate, and translated in many English editions as "walk." On Paul's literal and figurative use of this verb and on "the wider linguistic field of words associated with walking” in Pauline texts, see Banks, "Walking' as a Metaphor," 303-13. See also Konsmo, Pauline Metaphors, 100-107; Williams, Paul's Metaphors, 198-99.

37. "Walk [ $\pi \varepsilon \rho \iota \pi \alpha \tau \tilde{\eta} \sigma a \mathrm{l}$, ambuletis] worthy of the calling to which you have been called" (Eph. 4:1).

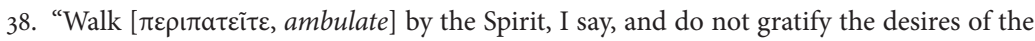
flesh" (Gal. 5:16).

39. "As you therefore have received Christ Jesus the Lord, continue to walk [ $\pi \varepsilon \rho\llcorner\pi \alpha \tau \varepsilon i \tau \varepsilon$, ambulate] in him" (Col. 2:6).

40. "Caritatem voco motum animi ad fruendum Deo propter ipsum et se atque proximo propter Deum.” Augustine, De Doctrina Christiana, 86 (3.10.16).

41. "Pes animae recte intelligitur amor: qui cum pravus est, vocatur cupiditas aut libido; cum autem rectus, dilectio vel charitas" Augustine, Enarrationes in Psalmos 1-50, 202 (Ps. 9:15) [The foot of the soul is rightly understood to be love; which, when crooked, is called greed or lust; but when upright, love or charity]. For a discussion of the use of Augustine's commentary on the psalms in medieval England, see Kuczynski, Prophetic Song: The Psalms as Moral Discourse in Late Medieval England, 21, 47-48. 
charity walks, advances, and ascends. ${ }^{42}$ Perhaps not surprisingly, the ladder made a particularly appropriate motif for conceptualizing the upward trajectory of charity. In his early fourteenth-century poem on the Seven Sacraments (c. 1300-1350), William of Shoreham bemoans the fact that "heuene his heize [high], and we bep hevy." He asks, "How scholde we pider [get there] panne? Bi leddre." ${ }^{43}$ This is a ladder made not of wood but of charity, its rungs consisting of "gode peawis," or good behaviors. ${ }^{44}$ For Augustine, pedestrian movement offers a register of inner psychology and of the relationship between the will (affectus) and the intellect (intellectus), the twin powers-or feet-of the soul, and Peraldus later associated the pes affectus with the love that results from good works. ${ }^{45}$ As Freccero observes in his study of the stumbling pilgrim in Dante's Inferno, a person's gait offered an index of his or her spiritual decision making: choose love, and climb toward God; choose sin, and limp your way down to hell. ${ }^{46}$

In medieval sermons, walking was a popular theme for exploring the relationship between charitable works in this life and salvation in the next. As we saw in Mirk's Easter sermon, parochial processions symbolized-and occasioned discussion about-a congregation's ongoing and incremental effort to pass from sin to virtue. But a sermon on the theme of walking could, in fact, be used on numerous occasions throughout the year. The late fourteenthcentury sermons housed in the Royal 18 B. xiii collection-edited by Woodburn O. Ross under the title Middle English Sermons-includes a sermon for the third Sunday of Lent on the theme of ambulate in dilectione (walk in love)

42. "Ad abulandum et proficiendum et ascendendum caritas mouet; ad cadendum superba mouet" [Charity moves toward walking, progressing, and ascending: pride moves toward falling]. Augustine, Enarrationes in Psalmos 101-50, 62 (Ps. 120:5).

43. Poems of William of Shoreham, 2 (lines 43-49). Keiser explores Middle English adaptations of the Scala Claustralum and the concept of the ladder in both monastic and lay contemplative tradition in "The Laity and the Ladder of Perfection," 145-59. See also Brantley's discussion of ladder images in the Desert of Religion and the Speculum Christiani in Reading in the Wilderness, 115-17; Cahn, "Ascending to and Descending from Heaven," 697-724.

44. The cardinal virtues (faith, hope, charity) are often referred to as "peawis." MED, "theu," n., 3b. Charity constitutes the third of three "heued [head] thewes" in the Lay Folks" Catechism (8o, line 406), for example, but occupies a place of primacy in Cursor Mundi as the primary or "heuid [head] gode thewe of al" (1524 [line 27532]).

45. According to Wenzel, "affectus is, of course, not a matter of sentiment and 'feeling' but of will and love resulting in 'good works.'” Peraldus makes this connection, Wenzel notes, "equating the image of pes intellectus with 'good intention' and of pes affectus with 'work." Sin of Sloth, 65 .

46. "The figure of a man in the act of walking was quite literally the incarnation of the act of choice, for walking was simply choosing brought down to the material plain." Freccero, "Firm Foot on a Journey without a Guide," 42. See also Gillespie's discussion of the feet of the soul in English mystical writing. "Mystic’s Foot," 199-230. 
from Ephesians 5:2. ${ }^{47}$ Variant forms of the verb ambulare appear throughout the Bible, and in the upper and lower margins of the sermon's opening folio, a helpful scribe provides a list of twelve additional Sundays for which this sermon might also be appropriate. ${ }^{48}$

The collection's Ambulate sermon begins with a man named Ladas who ran so fast that he left no footprints behind. Ladas becomes an exemplar of perpetual motion directed toward God, as the sermonist urges his listeners to keep moving rather than standing still and allowing their feet to sink into the ground. "We muste nedis goye and not to stonde here in pis worlde," he warns. ${ }^{49}$ "Goye we lyghtly," he recommends, "not settynge oure fete of oure affeccion or loue to grettely pere-in." ${ }^{\circ}$ For the Ambulate-sermonist, moving or "going" has to do with directing oneself away from the stagnation associated with sin and towards eternal salvation: "He pat goyp here in pis world wurthelye, he shall com to pe liffe pat euermore is lastynge." ${ }^{51}$ Those who go "wurthelye" are like pilgrims on the move, "euermore spedynge hem in here weyes." ${ }^{2}$ Although we might expect the motif of the pilgrim to play a central role in a sermon on the theme of Ambulate, the sermonist is more interested in movement itself than in travel. Indeed, the sermonist spends a mere fifteen lines on the pilgrimage comparison before moving on to the more everyday movement of the sea and the sun. Just as the sea continuously moves, the sermonist explains, "so shulde man here in pis liffe euermore be sterynge [leading] and worchynge [working] good [w]erkes." ${ }^{53}$ And just as the sun unceasingly follows its daily east-to-west track in the sky, so should the layperson cultivate a daily routine of good works. Like the sun, never departing from its course, "lat hym do good werkes contynulye [. . .] fulffillynge [his] course of goodness to pat he com to a good ende; as doth pe sonne, pat day by day ne lettep nowthe [its] cours." ${ }^{54}$ Running, going, coursing-the sermonist repeatedly uses verbs related to pedestrian movement to describe the nature of this life and the layperson's ongoing struggle to live a life worthy of salvation. Although these verbs are all directed toward God and future salvation, they also point to tangible work in the here and now. With a clarifying pun, the sermonist explains that one gets to God not by traveling but by travailing:

47. Sermon 14, “Ambulate," in Middle English Sermons, 72-83. For a recent discussion of the sermon and the collection more generally, see Repertorium of Middle English Prose Sermons, 1381-82, 1406-8.

48. Middle English Sermons, 72, xlii.

49. Ibid., 74 (lines 26-27).

50. Ibid., 73 (lines 29-30).

51. Ibid., 74 (lines 3-5).

52. Ibid., 74 (line 29).

53. Ibid., 75 (lines 13-14).

54. Ibid., 75 (lines 33-38). 
"3iff so be that he traveyll and goye besely porow good [w]erkes," he explains, the layperson will "com to pe londe of liff and blisse." 55

Stasis and inaction are thus the hallmarks of sin: a man who is "not goyinge ne wirchynge [working] in good [w]erkes," he explains, "vexep corrupte and stynkynge porowe dedelye synne." ${ }^{56}$ The person who does not walk in love does not perform the good works that outwardly express his or her own feelings of charity. The sermonist sharpens the connection between ambulation and charitable good works by invoking Augustine's treatment of the foot of the soul in a discussion of the sciopod, a one-footed beast that offers an "ensample" of "how and in what maner pat we shall do and goye in pis werlde":

By pis beeste pat hap but on fote I vndirstonde euery Cristen man and womman pat owep to haue oon loue to God and to here evencristen. And skillefulliche may loue be likened to a fote, for pus seip Seynte Austyn, "Pes meus, amor meus - my fote is my loue." In pis fote ben v toes. Pe firste tooe is often tyme to penke on God. The second too ys oft tyme to speke and tell of hym to opur men. The pride too ys gladdely to here speke of God. The iiij too ys to flee pinges pat God hatep. The v too ys for to do pinges pat shuld plese God. On pis fote of loue shulde we goye to-Godwarde, aftur pe techynge of pe holy apostell Seynte Poule, ad Ephesios, quinto, "Ambulate in dileccione-goye in loue of God." ${ }^{37}$

I understand the beast with only one foot to be each Christian man and woman, who ought to have one love toward God and toward his or her fellow Christians. Love may be appropriately likened to a foot, for as St. Augustine says, Pes meus, amor meus-my foot is my love. This foot has five toes. The first toe is thinking about God often. The second toe is speaking to and telling other men about him often. The third toe is gladly hearing others speak about God. The fourth toe is fleeing things that God hates. The fifth toe is doing things that please God. On this foot of love, we should go God-ward, according to the teachings of the holy apostle St. Paul, in the fifth chapter of Ephesians: Ambulate in dileccione-go in love of God.

To walk in love is to do things that please God, and in doing these things, a person puts his or her feet on the right path. Carruthers has suggested that the sermonist never "goes anywhere" with his sciopod, that the fanciful image

\footnotetext{
55. Ibid., 76 (lines 29-30).

56. Ibid., 75 (lines 17-19).

57. Ibid., 77 (lines 3-4, 13-25).
} 
serves primarily as a "compositional device" that helps him organize his thoughts. ${ }^{58}$ But the image also draws on a broader discourse that roots charity in the human body and in feet made for walking. Not all of the toes are linked with movement or works - while the fourth and fifth toes refer to fleeing from the bad and pursuing the good, the first three are linked with thinking, speaking, and listening. But together, the five toes make up a foot that can compel a person "Godwarde." Although sciopods were often relegated to the monstrous outer margins of mappae mundi, as Carruthers reminds us, the one-legged "beeste" in this sermon perhaps also resembles Augustine's singular foot of the soul or, in Gregory the Great's formulation, the person who balances on the foot of the love of God without allowing the foot of the love of the earth to touch the ground. ${ }^{59}$

\section{Churchward Steps}

The Ambulate-sermonist opposes charitable movement with slothful inertia when he explains that the best way to stray from the path to salvation is by not doing anything at all, "not goyinge ne wirchynge in good [w]erkes." ${ }^{60}$ Stasis and inaction were, of course, closely associated with sloth. For laypeople, the sin of sloth was often characterized by slowness in the service of Goddelaying penance, neglecting one's prayers, skipping or arriving late to the Mass. Sloth ran contrary to charity and to the love of God and neighbor because, as Chaucer's Parson explains it, sloth squelched a person's positive and productive desires: it "binimeth him the love of alle goodnesse," leaving him feeling "anoyed and encombred." ${ }^{61}$ And in annihilating positive desires, sloth could result in what the Parson calls "undevocioun," a state of spiritual inaction that inhibits, among other things, the performance of good works. ${ }^{62}$ Bernard of Clairvaux associated devotionis inopia, or lack of devotion, with

58. Carruthers, "Allegory without the Teeth," $36-37$.

59. Freccero notes that, in his homily on Ezekiel, Gregory "identifies the feet as love of God and love of the world." When a soul "supports itself, with all virtue, on the love of God alone," Gregory explains, it stands on one foot, the foot of love of God, and "suspend[s] above the earth the foot of the love of the world which it had been accustomed to placing on the ground." "Firm Foot on a Journey without a Guide," 40.

60. Middle English Sermons, 75 (lines 17-18).

61. Chaucer, Canterbury Tales, fragment 10, lines 678, 687.

62. "Thanne comth undevocioun, thurgh which a man is so blent, as seyth Seint Bernard, and hath swich langour in soule, that he may neither rede ne singe in holy chirche, ne heere ne thinke of no devocioun, ne travaille with hise handes in no goode werk that it nis to him unsavory and al apalled." Ibid., lines 723-24. 
spiritual inertia in the monastery, ${ }^{63}$ but later authors, such as Chaucer, linked the absence of devotion with the end of charity itself. Indeed, while charitable good works were associated with physical movement and with the climb to salvation, sloth was construed as preventing laypeople from learning and practicing the very things that, as the author of the vernacular sermon collection Jacob's Well (c. 1375-1400) puts it, "may rayse [them] vp fro deth of slowthe to pe lyif of deuocyoun \& of amendment." ${ }^{34}$ In sermons and handbooks, slothful inertia is consistently associated with a failure to move, a failure to rise up from sin. The slothful person flatly rejects the opportunities available to him or her, particularly the metaphorical ladder to heaven that charitable works and the avoidance of sin provided. In fact, in the Book of Vices and Virtues, the slothful person is compared to a prisoner who refuses to climb altogether, a prisoner who would rather languish and die than "clymbe vpon a ledder \& goo his wey." ${ }^{65}$

Slothful undevocioun rendered laypeople spiritually inert and uncharitable. It also isolated them from the church, in part by keeping them off their feet, and the author of Jacob's Well emphasizes the slothful person's physical remoteness. Early on in a sermon devoted to sloth, the Well-author suggests at some length that the sin involves loving one's bed more than God:

pou louyst nozt pi god feruently abouyn all thyng, but settyst pi loue slowly in god; \& whan pou castyth pe all to lyuen in reste, \& to slepe myche, to lyen longe in pi bed, \& whanne pou louyst to sytten stylle \& to don nouzt ellys, to lenyn on pin elbowe, to lyen on-long on pi o syde. ${ }^{66}$

You do not love your God fervently above everything else, but rather you set your love slowly in God; and when you apply yourself to living in rest

63. In one of his Sermons on the Song of Songs, Bernard explains that devotionis inopia results in a monk's inability to sing the psalms, read, meditate, or take pleasure in prayer. Devotionis inopia is associated with stumbling and falling: "Non sine causa sane ab heri et nudiustertius invasit me languor iste animi et mentis hebetudo, insolita quaedam inertia spiritus. Currebam bene; sed ecce lapis offensionis in via: impegi et corrui. Superbia inventa est in me, et Dominus declinavit in ira a servo suo. Hinc ista sterilitas animae meae, et devotionis inopia quam patior." Bernard of Clairvaux, Sancti Bernardi Opera, 2:107-8, lines 20-24 [It is not without reason that this languour of soul, this dullness of mind has laid hold of me since yesterday and the day before, an unwonted impotence of the spirit. I was running well; but there in the way was the stumbling block: I tripped and fell. Pride was discovered in me, and the Lord has turned away in anger from his servant. Hence the barrenness of my spirit and the resourcelessness of devotion that I suffer]. English translation is taken from Walsh, Bernard of Clairvaux, 3:76.

64. Jacob's Well, 116 (lines 32-33).

65. Book of Vices and Virtues, 27 (lines 22-41).

66. Jacob's Well, 103 (lines 22-27). 
and sleeping too much, to lying for a long time in your bed; and when you love to sit and do nothing, to lean on your elbow, to lie on your side for a long time.

The slothful person's love of sleep prevents him from learning his prayers and the basic tenets of the faith and also inhibits his ability to undertake "holy \& gode occupacyouns." ${ }^{\prime 67}$ More likely to be found in his bed than in the church nave, the slothful person is characterized by his spiritual inattention, his love of lying down, and his physical distance from the church. He "tarye[s] longe fro pe cherche \& fro dyvyne seruyse," ${ }^{\prime 6}$ and even stands outside the churchyard, afraid to enter it. ${ }^{69}$ If a "slow man"70 makes it to church at all, he sleeps his way through both the sermon and the prayers for the living and the dead. In his early fourteenth-century handbook Handlyng Synne, Robert Mannyng warns that lounging in bed in this life means languishing in Purgatory in the next: "For eury oure pat pou per yn lay, / Yn purgatorye pou gest py pay."71 Those who sleep late lose an opportunity to serve God, a failure that Mannyng emphasizes in an end-rhyme juxtaposition between not rising and not serving. ${ }^{72}$ As Mannyng brings his long discussion of sloth to a close, he returns to the idea of rising up, this time in reference not only to rising from sin and from the comfort of one's bed but also to rising to a good end at the Last Judgment: "Ne be we nat slogh but sone vpryse, / Ne drede vs pan on no wyse, / But, hope alle to gode endyng." ${ }^{73}$ He may even be making a near-pun here on hoping (hopen) and hopping (hoppen), as Langland does in passus 17 of Piers Plowman with hope and hippen-a verb that, like hoppen, refers to forward movement. ${ }^{74}$

67. Ibid., 104 (lines 2-3).

68. Ibid., 108 (line 7).

69. "Bou faryst as he pat dar nozt entryn pe cherch-zerd for pe snayl pat puttyth his horn oute azens hym.” Ibid., 107 (lines 2-3).

7o. Ibid., 103 (line 10).

71. Mannyng, Handlyng Synne, ed. Sullens, lines 4783-84.

72. "For sloghnes pey wylnat ryse; / lyggyng [lying] yn synne, ys lore [lost] seruyse." Ibid., lines 4791-92.

73. Ibid., lines 5319-21.

74. In passus 17, Hope comes "hippynge," only to "drawe" himself back, like a duck from a falcon, when he spots the Samaritan. "Hope cam hippynge after, that hadde so ybosted / How he with Moyses maundement hadde many men yholpe; / Ac whan he hadde sighte of that segge, aside he gan hym drawe / Dredfully, bi this day, as doke dooth fram the faucon!" Langland, Vision of Piers Plowman: A Critical Edition of the B-Text, ed. Schmidt, 17.60-63. Unless otherwise indicated, all Piers quotations are taken from this edition of the B-text, hereafter referred to as Langland, Piers Plowman. MED, "hoppen" v., 2b: "to hop, leap, bound, bounce." $M E D$, "hippen" v., 1a: "of persons, animals, things: to leap, spring, hop, bounce." 
The slothful person's physical and spiritual remoteness from church comes with dire consequences, even exclusion from its prayer network, and the Wellauthor illustrates the problem with a shocking tale of postmortem disenfranchisement. The story takes place during the burial service for a man who was notoriously "slawe and sluggy" when it came to church attendance. 75 "Slawly he com to pe cherche, \& selde [seldom], \& late," the Well-author writes, and once there, he spent his time either sleeping or jangling so loudly that it "lettyd [prevented] manye opere fro pe heryng [hearing] of dyvin seruyse."76 During the Office of the Dead, "whil his body lay on pe bere [bier] in pe cherche, \& clerkys seydin 'Placebo \& dirige' for his soule," something astonishing happens: the crucifix comes to life. ${ }^{77}$ The figure of Jesus unpins his hands from the cross in order to cover his ears and muffle the sound of prayers being said on the slothful man's behalf:

Pe crucifix on pe bere loosyd his handys fro pe crosse, \& stoppyd his eerys wyth his handys. Pe peple sey3 pis, \& merueyledyn sore. An holy preest prayid god wyth pe peple, to wyten what pat ment. A voys fro a-bouyn seyde to hem: "Pis cursyd man wolde neuere for slauthe heryn my woord, ne don per-after, ne heryn my seruyse in holy cherch deuoutly; perfore, his soule is in powere of feendys dampnyd. Perfore, myn ymage on pe cros stoppyth his erys, to schewe zou bat I, god, stoppe myn erys in heuen, pat I here no prayere prayed for hym in holy cherche. Perfore, prayeth no more for hym, for he is dampnyd." ${ }^{8}$

The crucifix on the bier lifted his hands from the cross and stopped his ears. The people saw this and marveled. A holy priest prayed with the people in order to understand what it meant. A voice from above said to them, "This cursed man would never, because of sloth, hear my word or follow it, nor would he devoutly hear my service in church. Therefore his soul is in the power of damned fiends. Therefore, my image on the cross stops his ears to show that I, God, stop my ears in heaven, and that I hear none of the prayers said for him in holy church. Therefore, pray no more for him, because he is damned."

The story puts the consequences of sloth in stark relief: God turns a deaf ear on prayers uttered on behalf of those who do not listen to the Mass and

\footnotetext{
75. Jacob's Well, 110 (line 16).

76. Ibid., 110 (lines 16-17, 19-20).

77. Ibid., 110 (lines 21-22).

78. Ibid., 110 (lines 22-32).
} 
those who come to church late or not at all. Slothful uninvolvement ultimately results in exclusion from the parish and its prayers. When God stops his ears and refuses to hear any prayers on the man's behalf, he denies him access to one of the major spiritual benefits of parochial membership. The story of the deaf crucifix illustrates the spiritual and physical remoteness that sloth can engender, both in this life and after death. Indeed, the man's spotty church attendance and his inattention in the nave not only cut him off from the prayers of the parish but render him even further removed from future salvation; with no prayers to speed him, the slothful man now faces, at best, a much longer tenure in Purgatory.

In distancing themselves from the church, slothful people ultimately distance themselves from heaven, and the Well-author punctuates this point at the end of the sermon by turning to the theme of walking. The final exemplum concerns a hermit who, for the sake of his own convenience, thinks about moving his cell closer to the well where he gets his water. He "thouzte to haue esyd hym wyth schortere travayle."79 An angel appears to "folewyn hym, \& tellyn his steppys" and explains why the move might not be a good idea. ${ }^{80}$ While the devil will count the hermit's "synne ward" steps, the angel keeps a tally of his hardworking steps: "I noumbre pi steppys in pi trauayle," the angel claims, "for to schewyn pe noumbre perof a-for god azens pe feend, pat pou ther-thrugh mowe haue mede [be rewarded] in heuen" ${ }^{81}$ The hermit accordingly moves his cell further away in order to have "manyere steppys" and "more mede." ${ }^{82}$ Shifting his attention back to his lay listeners, the Wellauthor explains that, while "pe feend wryteth \& noumbryth pe slauthe [sloth], slugnes [laziness], \& ydelnes, idell woordys, ianglyng, \& pi rownyng [snoring] in cherche," angels keep track of their "steppys to cherche ward." ${ }^{83}$

\section{Mangled Feet}

As part of the effort to link sloth with inaction and physical remoteness, late medieval depictions of the sin pay close attention to the sinner's feet, often associating them with disease and deformity. In the Prick of Conscience, for example, when the author catalogs the maladies that souls will endure in Purgatory, he condemns the slothful to "pe potagre and pe gout," both of which

\footnotetext{
79. Ibid., 111 (line 7).

8o. Ibid., 111 (lines 9-10).

81. Ibid., 111 (lines 15, 11-14).

82. Ibid., 111 (lines 18-19).

83. Ibid., 111 (lines 20-21, 25).
} 
caused painful inflammation in the joints of the feet and toes. ${ }^{84}$ And in a gruesome rendering of the "deformed and myschapyn" Seven Deadly Sins from a fifteenth-century Carthusian miscellany, sloth has broken and mangled feet. An accompanying prose text describes the image as "a vision of saules pat war dampned \& put to helle after pe jugement," some of whom, presumably the slothful, "had fete al to gnawyn and bun [bound] as pai wer brokyn." 5

The Well-author also turns to diseased feet, this time in a story about avarice that, like his exempla about sloth, encourages sinners to get back on the path to salvation through good works and the avoidance of sin. The story begins by chronicling a good man's eventual consumption by avarice. After a lifetime of giving "all pat he my3t spare" to the poor, he begins to think more about himself than those in need:

In his age he dredde pouerte, $\&$ to ben bedrede, nozt trustyng full pat god schulde kepyn hym in his age as he dede in his zouthe. He lefte almesdede, \& 3 af hym full to coueytise, \& gaderyd hym to-gedere a gret summe of monye. Panne fell on his fote a maladye, pat it rotyd, \& in lechecraft he spendyd all pat he had gaderyd. ${ }^{86}$

In his old age, he was afraid of becoming poor and bedridden. He did not trust that God would take care of him in his later years the way He had when he was young. He abandoned almsgiving and gave himself over to avarice, and he accrued for himself a great sum of money. Then his foot began to rot, and he spent everything that he had saved on medical care.

The man abandons almsgiving and gives himself over to greed, ultimately refocusing all of his energy on himself and his own coffers. He is so thoroughly covetous that the sin eats away at his body, causing his foot to rot and ultimately confining him to his bed, a site the Well-author elsewhere associates with both spiritual neglect and social isolation. Facing the amputation of his foot, the avaricious man experiences a kind of charitable conversion as he weeps in his bed the night before his operation:

Whyle I gaf almes, I was heyl in alle my lymes, to getyn my lyiflode, \& now, in my coueytise, I am lame, and to-morwyn my rotyn foot schal be smyten of. My monye is spent per-aboute, I am a beggere. Allas, pat euer gadryd I

84. Prick of Conscience, line 2993.

85. Brantley, Reading in the Wilderness, 252-56 and fig. 6.25; qtd. in Wenzel, Sin of Sloth, 237, n. 64 .

86. Jacob's Well, 125 (lines 7-14). 
monye on hepe, to trustyn pere-vpon, \& lefte myn almesdede! God, I crye pe mercy! $!^{87}$

While I gave alms, my limbs were healthy enough to help me earn my living. Now, in my avarice, I am lame, and tomorrow my rotten foot will be cut off. My money has been spent, and I am a beggar. Alas that I ever trusted that heap of money and gave up almsgiving! God, I cry mercy!

An angel appears, and when the man repents_- "I haue synned!" 88 - the angel touches his foot and heals it. When the doctor arrives the next morning "to smyten of his fote," he finds his patient "goyng at pe plow3, for he had founde a bettyr leche pan him." ${ }^{89}$ The story of the rotten foot appears in a section devoted to avarice, but it makes a broader appeal to the idea of going toward God through penance and good works. As we know from the Ambulate sermon, Augustine likened charitable love to a foot that moves in the direction of God rather than sin, and in Jacob's Well, rotten feet set selfish misers on the wrong path: "Here [their] fote, pat is, here [their] loue rotyth in coveytise," the Well-author writes, "pat pei loue nozt god, ne holy cherch, ne pore peple, ne truthe, ne vertue."9o And the more they "rotyn in here [their] foot of loue," the more they drift away from God and the church, and "the slawlyere [they] gon to goddys servyse, \& pe werse kepyn pe halyday \& goddys comaundmentys." ${ }^{11}$

The story of the rotten foot points to the destruction wreaked by greed, but it also speaks to the more general concern that those who sin do not go the way of God, nor do they contribute to the charitable and penitential practices so closely associated with the parish. The exemplum chronicles an avaricious man's retreat from both; he trades almsgiving for avarice, and the rotting of his foot causes him to focus his attention on bodily "lechecraft" rather than his spiritual health..$^{2}$ Importantly, however, the man changes his course through penance, and the next morning he rises from his bed and plows his fields. The man's last-minute repentance gives him readmittance into the penitential economy of the parish while his turn to the plow taps into the traditional spiritualization of agrarian metaphor, a topic to which I turn my attention in chapter 4. Given the distinctively collective nature of agricultural labor, the man's plowing perhaps also signals his renewed commitment

\footnotetext{
87. Ibid., 125 (lines 17-22).

88. Ibid., 125 (lines 27-28).

89. Ibid., 125 (lines 30-32).

90. Ibid., 126 (lines 1-3).

91. Ibid., 126 (lines 18-20).

92. Ibid., 125 (line 13).
} 
to work that benefits others. Indeed, we might be reminded here of Chaucer's plowman, the "trewe swinker" who loves God and neighbor and lives in "pees and parfit charitee." ${ }^{93}$ In the Well-author's sermon, a layman who had retreated from charity and penance resumes both on healthy feet.

\section{The "Wikkede Way" to Salvation}

The metaphorical association between walking and salvation receives one of its most extended treatments in Piers Plowman, an epic poem framed and motivated by the motif of pedestrian movement. ${ }^{94}$ Replete with walkers, wanderers, and pilgrims, the poem begins with the narrator resting on a hillside, weary from wandering, and ends with Conscience vowing to "walken as wide as the worlde lasteth" as he searches for Piers. ${ }^{95}$ The theme even dictates the poem's formal division into passus, or steps. ${ }^{96}$ Langland first activates the relationship between foot travel, charity, and salvation in passus 1 , when the dreaming narrator encounters the figure of Holy Church. Their wide-ranging dialogue centers on the question of salvation-the narrator wants to know how to save his soul. Throughout their conversation, Holy Church returns again and again to truth and love and the role that both should play in shaping individuals and communities. Her discussion of Lucifer's fall introduces the traditional association of godly feet with good works and salvation; Lucifer put his foot in the north, Holy Church explains, via Augustine, and plummeted down to hell. ${ }^{77}$ But those who "werche wel," she instructs, will end in truth and may be sure, moreover, that their souls will "wende to hevene." ${ }^{8}$ Truth is the very product of love, Holy Church tells the bewildered dreamer, and it inheres in both working well and in avoiding sin. Toward the end of the passus, Holy Church uses the exhortatory letter of James to draw an explicit

93. Chaucer, Canterbury Tales, fragment 1, lines 531-32.

94. For Zeeman, the "activity of travel" constitutes "the great imaginative motif of the whole work." "Piers Plowman and the Pilgrimage to Truth," 8-9. Dyas observes multiple "modes" and "patterns" of pilgrimage in Langland's poem. Pilgrimage in Medieval English Literature, 145-70.

95. Langland, Piers Plowman, 20.382.

96. As Davlin observes in "Devotional Postures in Piers Plowman B," 162. And yet although "the poem's own name for its divisions" seems to suggest "the stages of a journey," Middleton warns that "attempts to recount the whole narration of this journey as a developing succession of acts and events tend to emphasize discontinuity rather than progression." "Narration and the Invention of Experience," 92.

97. Langland, Piers Plowman, 1.116-19. Hill discusses Augustine's notion of the twin feet of the soul in relation to Langland's characterization of Lucifer in "Satan's Pratfall and the Foot of Love," $153-62$.

98. Langland, Piers Plowman, 1.130, 132. 
connection between faith, works, and human feet. "James the genitle jugged in hise bokes," she says,

That feith withouten feet is feblere than nought,

And as deed as a dorenail but if the dedes folwe [follow]:

Fides sine operibus mortua est. [Faith without works is dead.] ${ }^{99}$

As Mary Carruthers points out, Holy Church's translation of fides sine operibus employs a bilingual pun on feet and faites, the French word for deeds. ${ }^{100}$ In doing so, it also taps into the broader association of devotion, charity, and the avoidance of sin with foot travel: faith requires deeds (faites), and deeds require feet. Without the two, faith is defunct and inert-a claim that brings to mind the Parson's warning that sloth can lead to the death of body and soul. $^{101}$

Holy Church's pun is part of her extended commentary on Truth, the meaning of which she never fully clarifies for the dreamer. Her inability to do so becomes, in Laurie Finke's formulation, "a measure of the difference or the distance between language and what it represents," a distance that leaves the dreamer longing for "a language that can express experience unequivocally." ${ }^{102}$ The dreamer wants to know what truth is, but even more importantly, he wants to know where it is and how to get there. The bilingual pun that Holy Church offers by way of explanation only complicates things further because parsing its meaning requires a process of translation, analysis, and contexualization. ${ }^{103}$ Her later description of love as the "gate that goth into hevene" is perhaps even more problematic in this vein because it makes an implicit reference to the concept of walking-one walks through an open gate-without explicitly connecting that idea to her earlier example of faith that has no feet at all. ${ }^{104}$ Holy Church moves from footless faith to the implied footpath to heaven's gates without ever explaining how the footless layperson might acquire feet, or how he might then use those feet as a means to salvation.

Will's allegorical map to truth at the end of passus 5 would seem to work toward closing this interpretive gap. In passus 1 , the dreamer repeat-

99. Ibid., 1.185-87.

100. Carruthers, "Imaginatif, Memoria, and 'The Need for Critical Theory' in Piers Plowman Studies," 112; Davlin, Game of Heuene, 41-42.

101. Sloth results in the "deeth of the soule and of the body also." Chaucer, Canterbury Tales, fragment 10, lines $726-27$.

102. Finke, "Truth's Treasure: Allegory and Meaning in Piers Plowman," 59.

103. Finke observes that "although the question changes, the rhetorical context does not. Commentary necessitates further commentary. Texts proliferate, but the substance, the thing that Will seeks, remains unattainable." Ibid., 61.

104. Langland, Piers Plowman, 1.205. 
edly asks for instruction on truth and on soul saving, and at the end of passus 5, it is Piers who offers the very kind of practical information that the dreamer has been longing for. After the well-known confession of the Seven Deadly Sins, and after Repentaunce's long prayer to God, "a thousand of men" respond to Hope's rallying cry by asking Christ to grant them the grace to "go to Truthe." ${ }^{105}$ But because nobody knows the way there, they wander around aimlessly like beasts on a hillside. ${ }^{106}$ They come upon a decorated pilgrim who, despite his many badges, can offer no help. He knows nothing about Truth or his shrine, and he has never heard any other pilgrim ask about it, either. At this very moment, Piers the Plowman appears and offers to show them the way to truth. "If ye wilneth to wite where that he dwelleth," he claims, "I shal wisse yow the wey wel right to his place." ${ }^{107}$ He then provides a complex map of an allegorical itinerary that begins in the region of meekness, conscience, and neighborly love before winding through the Ten Commandments and ending at the castle of Truth. Each place on the map corresponds to a spiritual or behavioral ideal: for example, after "go[ing] thorough Mekenesse" and "com[ing] into Conscience,"108 Piers tells his listeners to proceed along a brook called "Beth-buxom-of-speche" until they come to a ford called "Youre-fadres-honoureth." ${ }^{109}$ As the itinerary adheres more and more closely to specific catechetical teachings (moving from the general principle of Meekness, for example, to one of the Ten Commandments), the places become longer and longer strings of words: "Swere-noght-but-if-it-be-for-nede- / And-nameliche-on-ydel-the-name-ofGod-almyghty," and "Coveite-noght-mennes-catel-ne-hire-wyves- / Ne-noonof-hire-servaunts-that-noyen-hem-myghte."110

The map seems to offer a fairly straightforward and practical solution to the problem faced by the wandering beast-pilgrims who cannot find their way. In associating the journey to Truth with foot travel, the passage dishes up a panoply of verbs related to movement-bowen, ${ }^{111}$ lepen, ${ }^{112}$ blenchen, ${ }^{113}$ for example. Piers warns the pilgrims to keep moving at certain locations_-"stynt

105. Ibid., 5.510, 512.

106. "Ac there was wight noon so wys, the wey thider kouthe, / But blustreden forth as beestes over baches and hilles." Ibid., 5.513-14.

107. Ibid., 5.554-55.

108. Ibid., 5.561-62.

109. Ibid., 5.566-67.

110. Ibid., 5.570-71, 573-74.

111. "Boweth forth by a brook." Ibid., 5.566. MED, "bouen" v., 6c: "to go forth, go out, depart."

112. "Ye shul lepe the lightloker." Langland, Piers Plowman, 5.569. MED, "lepen" v., 4a: "to travel by hops or jumps, bound."

113. "Thanne shaltow blenche at a bergh." Langland, Piers Plowman, 5.580. MED, "blenchen" v., 2a: "to change one's course, turn (in a certain direction); turn around, retreat." 
thow noght," he says, at the stumps called "Do not steal" and "Do not kill"an injunction that brings to mind the Ambulate sermon and its emphasis on going rather than standing still. ${ }^{114}$ The pilgrimage map presents the journey to truth as a step-by-step process, a point that the pilgrims themselves seem to acknowledge when they express their longing for a guide that can "folwen [them] ech a foot." 115

At first glance, then, Piers's map to truth seems right at home with the traditional association of walking with spiritual action-what better way to take up Paul's injunction about walking in love than with a pedestrian tour of neighborly love and the Ten Commandments? Although the map and its wordy place-names may compensate for earlier linguistic and interpretive problems, as others have suggested, ${ }^{116}$ I want to focus instead on the map's misleading emphasis on travel rather than travail. What makes Langland's treatment of the metaphor of walking so different from what we have encountered in vernacular sermons is that, in insisting that the way to truth constitutes a pilgrimage, he focuses less on walking as spiritual work that is ongoing and labor-intensive and more on walking as a means to a particular geographical end. This is a map that reduces lifelong spiritual and behavioral goals into single-stop destinations and, as Mary Carruthers observes, fundamentally misconstrues actions as things:

The Ten Commandments are commands to action; one either does them or not. They are not really like brooks or towns or crofts, to be waded through or avoided. And to make substantives of them, things rather than actions, is to distort their real nature and to employ a false analogy. ${ }^{117}$

In representing the Ten Commandments as places rather than calls to action, the map ignores the importance of action itself. "Do not Covet" is not a place a person can walk to but rather an objective that a person achieves by actively eschewing covetousness: the work of becoming noncovetous is itself the goal, and yet Piers's map divorces that goal from the diligent, lifelong effort that

114. "Two stokkes ther stondeth, ac stynte [stop] thow noght there: / Thei highte 'Stelenoght' and 'Sle-noght' - strik forth [go, press on] by bothe." Langland, Piers Plowman, 5. 576-77.

115. Langland, Piers Plowman, 6.2.

116. Finke suggests, for example, that the map's "plodding, one-to-one correspondence between physical place and spiritual state" compensates for earlier epistemological failures. "Truth's Treasure," 63. For Mann, the map's wordy place-names "are naked of metaphor, simply straightforward didactic exhortations which refer themselves directly to real life." Langland and Allegory, 18-19.

117. Carruthers, Search for St. Truth, 64. See also Aers, who observes that Will's "attractive map" nevertheless "assumes the very resources that sinners lack." Salvation and Sin, 104. 
meeting it would require. ${ }^{118}$ The map implies, moreover, that there is only one way to achieve salvation, that no alternate or circuitous routes will suffice: travelers must visit each of these sites, and in the order prescribed. ${ }^{119}$

The map's shift from actual pilgrimage to a more interiorized or imaginary pilgrimage further obscures the relationship between walking and work. The journey is an interior one, it turns out, and Piers's listeners learn that once they have crossed the moat of mercy and entered through the gate of grace, they will find truth within themselves. ${ }^{120}$ But the work of getting to Truth-the work of living a life worthy of salvation-cannot be relegated to the imagination. Indeed, the point is not to imagine, but to act-to insure future salvation, that is, by making the climb, by doing the very things that bring one incrementally closer to God. Although the map assumes a journey on foot, it never takes full advantage of walking as a way of thinking through the active and laborious effort involved in saving oneself. It misconstrues the very travail of getting saved as travel, a pun that Langland deploys much later in the poem, when the dreamer first learns about the Tree of Charity: "I wolde travaille [...] this tree to se, twenty hundred myle," he claims, as if charity were something he could travel to rather than travail at or perform. ${ }^{121}$ We might be reminded here of the Middle English Ambulate sermon and its very different use of this pun; the only way to "come to pe londe of liff and blisse," the sermonist claims, is to "traveyll," by which he means to "go besely porowe good [w] erkes." ${ }^{\prime 22}$ As we have seen in a variety of texts, the metaphor of spiritually efficacious walking offered sermonists a way of aligning charity, the avoidance of sin, and the pursuit of salvation with bodily action and effort. To do these things is to climb one's way to God. Unlike the places along Piers's map, charity is not a destination, but a practice, and a lifelong one.

The actions that Piers transforms into dots on a map are also tenets and ideals that were taught from the parish pulpit: neighborly love, the Ten Commandments, the efficacy of penance, prayer, and almsgiving. But as pit stops on a pilgrimage route, they have been physically separated from truth and geographically removed from the parish, its rituals, and its teaching. Instead of being learned and practiced by a parish community, these ideals have become short-term stops to be visited just once by an ad hoc group of strang-

118. Strange has argued that Langland "flatten[s]" working into walking. "Willful Trope," 30.

119. As Harwood puts it, "to have disobeyed one dictate of the moral conscience would be to have turned aside from the road and never have got to Truth." "Piers Plowman" and the Problem of Belief, 149.

120. "And if Grace graunte thee to go in in this wise / Thow shalt see in thiselve Truthe sitte in thyn herte / In a cheyne of charite." Langland, Piers Plowman, 5.605-7.

121. Ibid., 16.10 .

122. Middle English Sermons, 76 (lines 29-30). 
ers on their way to someplace else. They have also been wrested away from the parish pulpit. Vernacular handbooks and sermon collections, filled as they are with treatments of the very topics that appear along Piers's pilgrimage route, were designed for use in the parish where, whether their contents were expounded by priests during their sermons or during confession, they formed part of a network of visual images, ritual practices, and local customs.

The step-by-step process of achieving salvation through charitable living and the avoidance of sin motivated and structured the ritual life of the parish. As a fundamentally collective enterprise, the charitable ideal was perhaps most fully expressed when the parish was on its feet in procession. Bearing palms a week before Easter or tracing the perimeter of the churchyard at Rogation, the parish walked together, celebrating its collective passage from sin to virtue while also acknowledging the many steps yet to come on the long road to salvation. Parishioners were reminded of the importance of staying on task-of putting one foot in front of the other, as it were-throughout the liturgical year. They participated in processions, of course, but they also listened to ambulate-themed sermons about sciopods, rotten-footed sinners, and angels who count churchward steps. And when they left church at the end of the Mass, they were exhorted to go with God. Ite, missa est, the priest would say-go, Mass is finished. Laypeople were taught to listen for the ite: "When pou heris say ite," writes the author of the Lay Folks Mass Book, "pen is po messe al done." ${ }^{123}$ A signal that the end is in sight, the command cues the congregation's final prayer of thanksgiving before going. But the ite also issues a call to action beyond the walls of the church-a call not just to go, but to go with God. After the final prayer, "wele pou may / In gods name wende pi way." $^{124}$

In the parish church of St. George in Trotton (West Sussex), a late fourteenth-century mural on the west wall of the nave offers a kind of visual guide to meeting this closing injunction (fig. 4) ${ }^{125}$ Christ sits in judgment on a rainbow at top center with the Seven Deadly Sins to his right and the Corporal Works of Mercy to his left; below him, Moses holds a pair of tablets inscribed with the Ten Commandments. ${ }^{126}$ As a depiction of the Last

123. Lay Folks Mass Book, 56 (lines 604, 606).

124. Ibid., 58 (lines 608-9).

125. For a comprehensive description of the painting, see Edwards, "Trotton's 'Abbreviated' Doom," 115-25; Tristram, English Wall Painting, 20, 259-60. Photographs of individual details available at http://paintedchurch.org/trottwks.htm and http://paintedchurch.org/ trottds.htm. On the painting's treatment of the Corporal Works of Mercy in relation to female piety, see French, Good Women of the Parish, 191-92.

126. This "accidental transposition" contradicts Matt. 25:31-33, in which the saved appear to God's right and the damned to his left; others have interpreted the reversal differently, sug- 


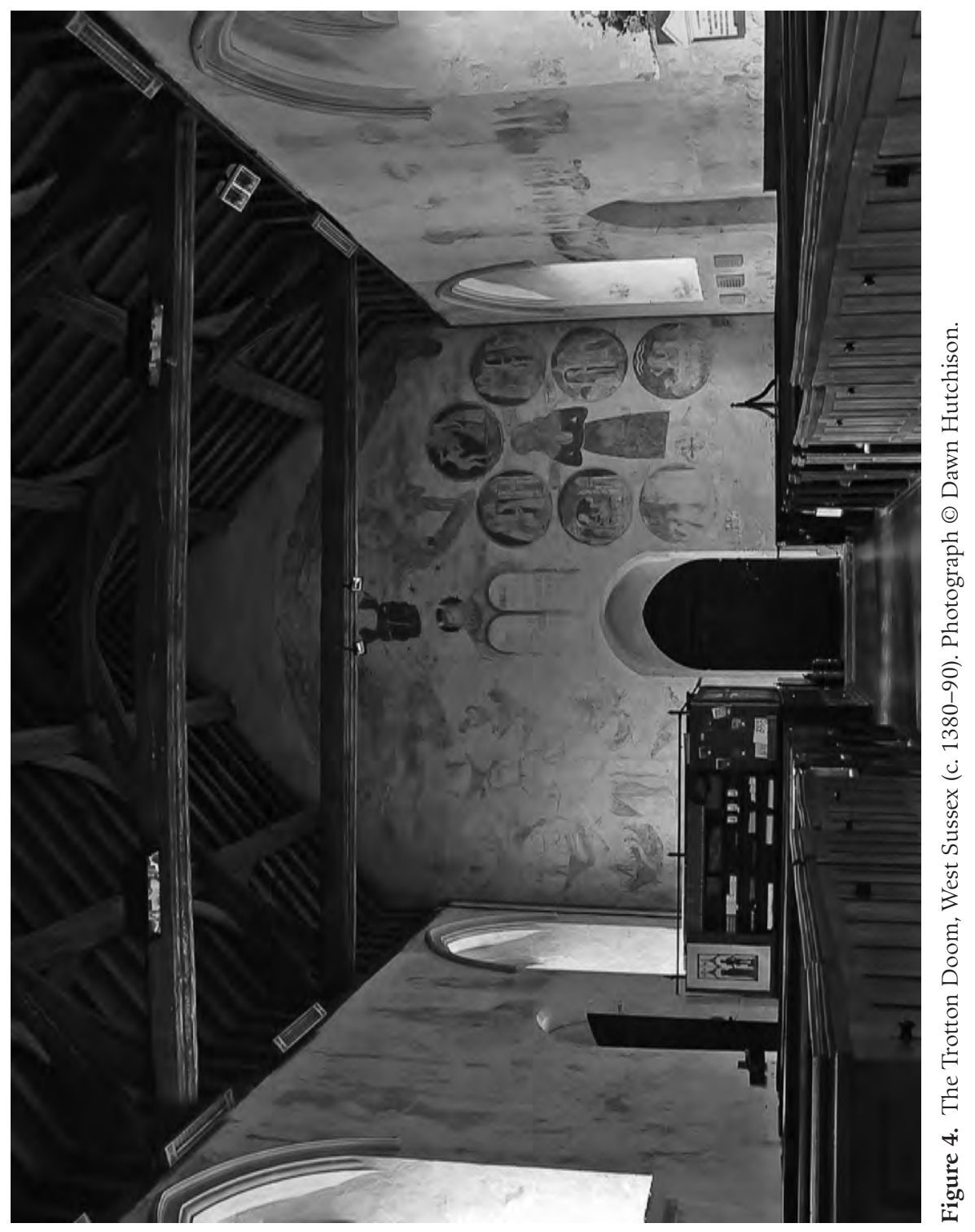


Judgment, the painting explicitly links charitable living with salvation: those who enact the Corporal Works will, like the naked soul at top right, enjoy an angelic welcome into the community of the saved. But the mural offers more than a glimpse into the future end of time. I want to suggest that, by virtue of its unusual location on the back wall of the church, the mural also reinforces the traditional association of charitable living with the mundane, step-by-step pursuit of salvation. Last Judgment paintings typically appear on the chancel arch above the high altar, looming over the congregation as they observe the Mass. At Trotton, however, the mural appears at the opposite end of the church, looming over the congregation as they turn around to exit the building, its imagery not only evoking the priest's closing injunction about going with God but encouraging the viewer to respond to that injunction by walking in charity rather than sin. The mural's guide to salvation certainly resonates with Piers's allegorical map to truth: follow the example set on the right side of the painting, the Trotton mural seems to suggest, and when you have completed the works of mercy, look for an angel and a cloud-shaped path leading to heaven. ${ }^{127}$ But instead of transforming lifelong practices into external places that have been disconnected from the ritual life of the parish, the Trotton mural offers a program of actions explicitly linked to the parish and its teaching. Avoid sin, keep the commandments, perform acts of charity: this is the stuff of Sunday sermons, a visual rendering of what parishioners regularly heard from the pulpit and a reminder of the liturgy's consistent emphasis on social reconciliation and mutual help. The mural issues a parting reminder to all parishioners as they walk west before exiting: ite, missa estwend Godward.

gesting that the Trotton artist, more accustomed to depicting the Last Judgment on the east wall, associated the north side of the church with heaven. Edwards, "Trotton's 'Abbreviated' Doom," 121-24. Medieval parishioners would have exited not through the door located directly underneath Moses (which leads into the tower), but through the door at the western end of the south wall. Moger and Wood, "Hundred of Dumpford," 36-37.

127. Benson has suggested that the mural's iconographical program as a whole not only "shows the visual conventions that lie behind Piers" but also "suggests their popular reception." Public "Piers Plowman," 188. 


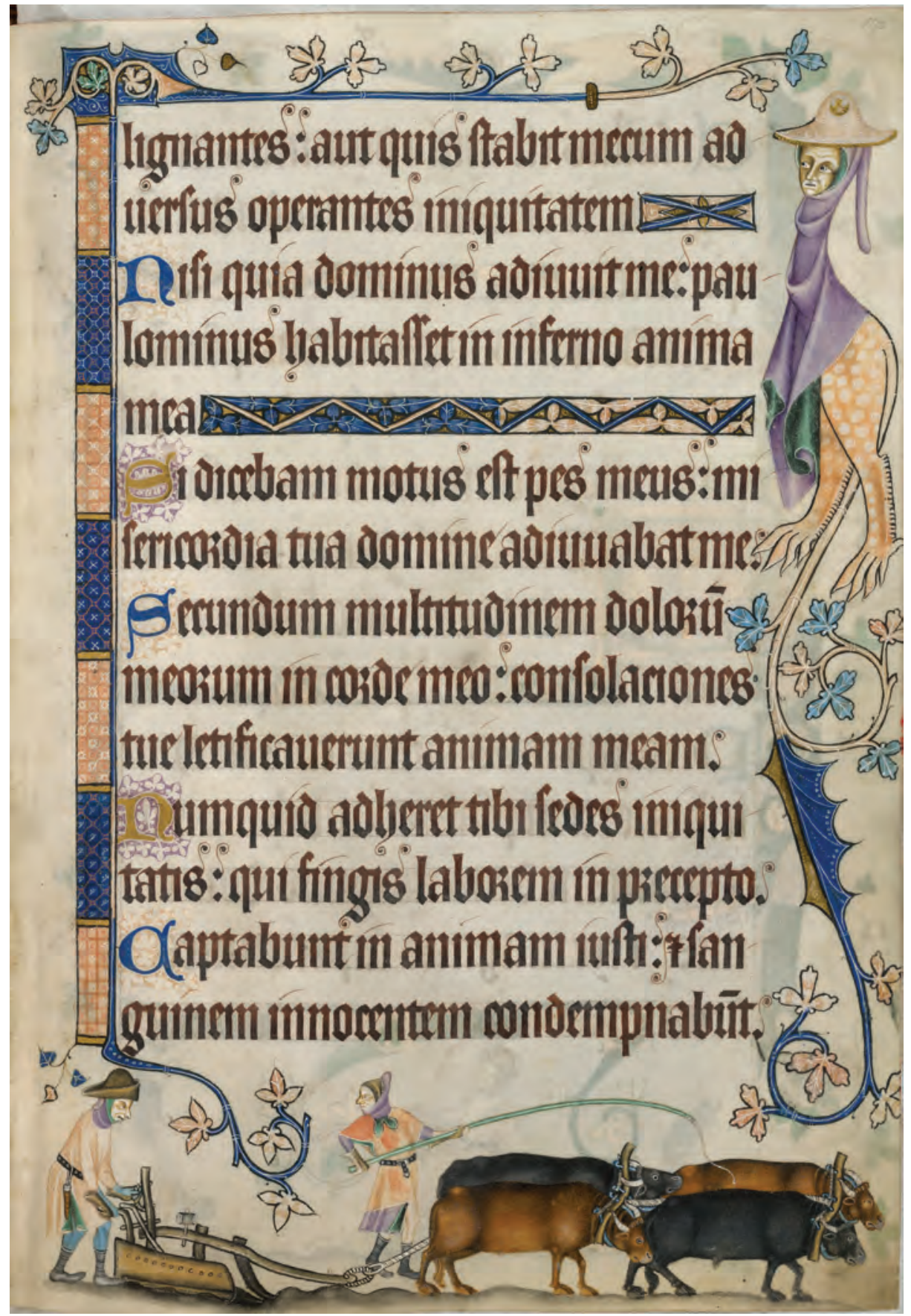

Plate 1. Plowing. (C) The British Library Board, MS Additional 42130 (c. 1330-45), fol. 170r. 


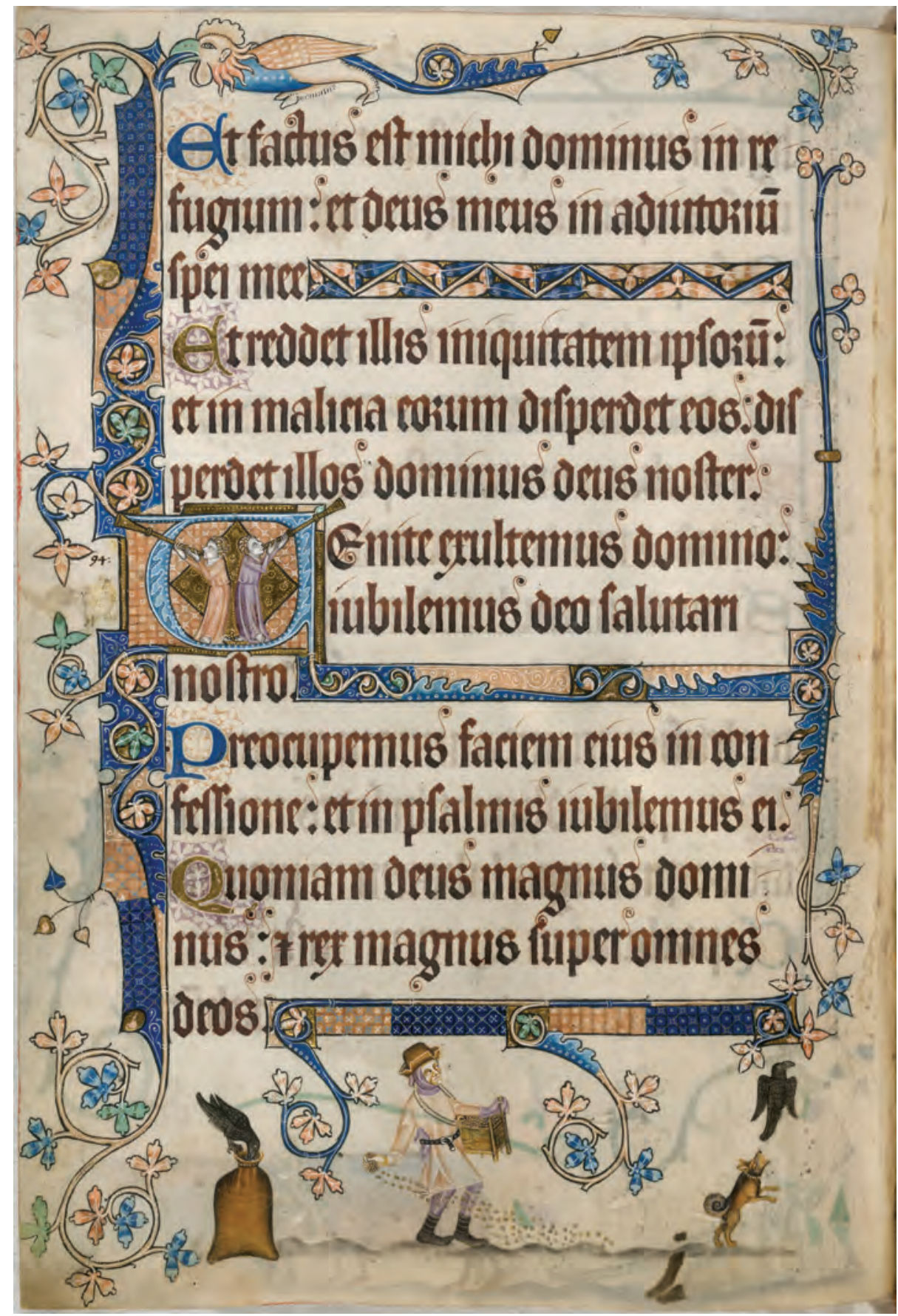

Plate 2. Sowing; Psalm 94. (C) The British Library Board, MS Additional 42130 (c. 1330-45), fol. $170 \mathrm{v}$. 




Plate 3. Harrowing; Sir Geoffrey's shield. () The British Library Board, MS Additional 42130 (c. 1330-45), fol. 171r. 


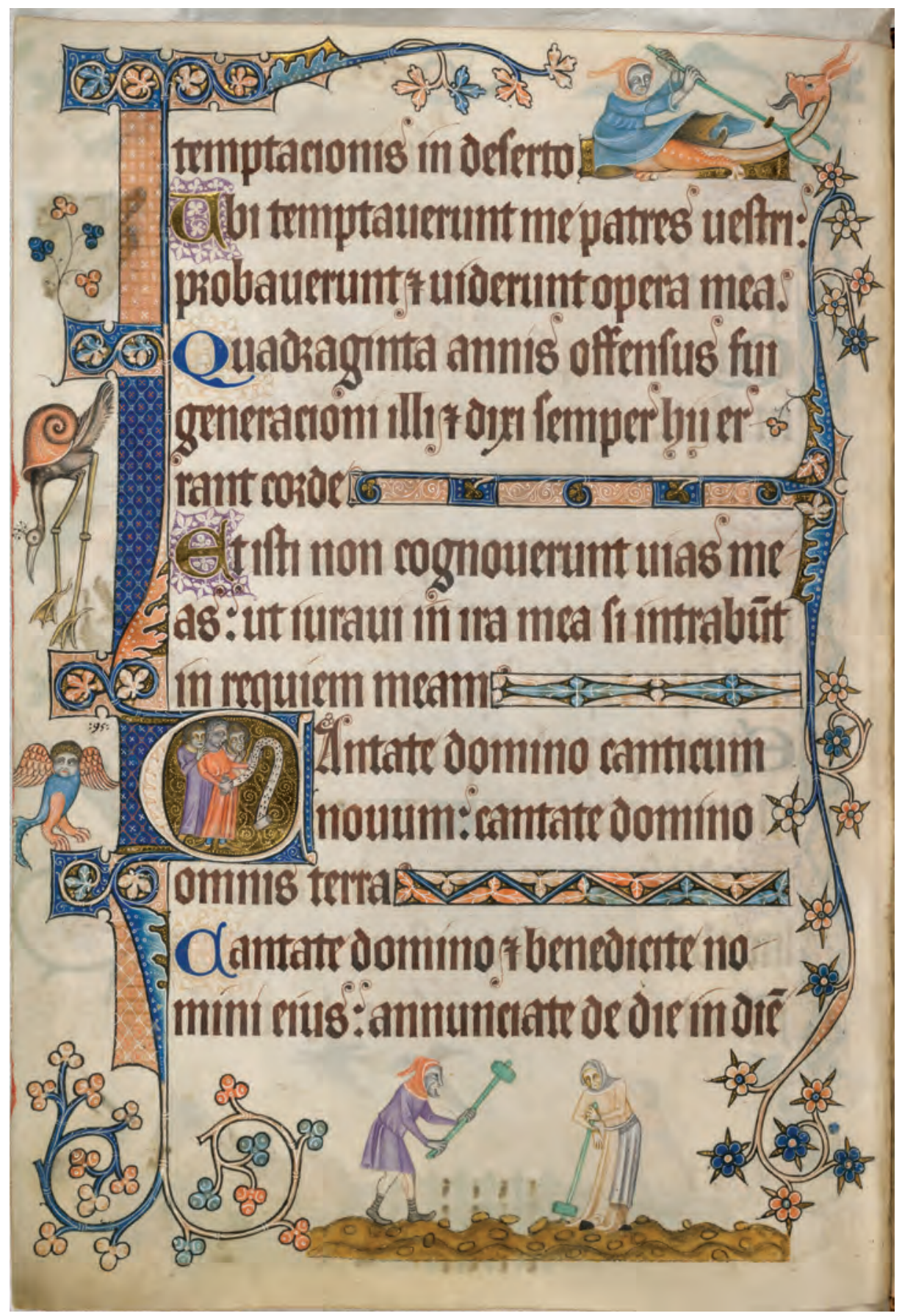

Plate 4. Clod-breaking; clerics with scroll. () The British Library Board, MS Additional 42130 (c. 1330-45), fol. 171v. 




Plate 5. Weeding. ( $)$ The British Library Board, MS Additional 42130 (c. 1330-45), fol. 172r. 


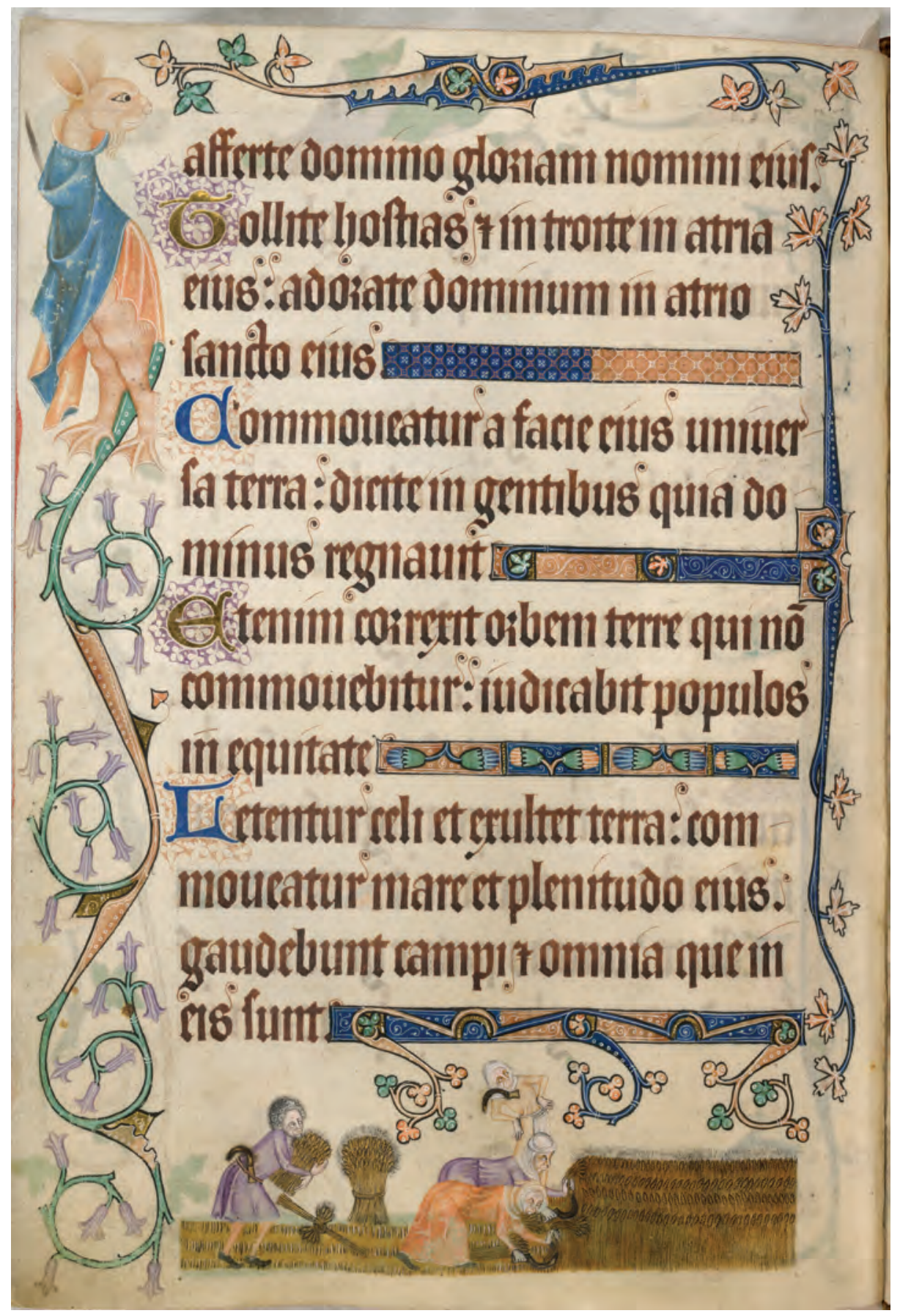

Plate 6. Reaping. (C) The British Library Board, MS Additional 42130 (c. 1330-45), fol. 172v. 


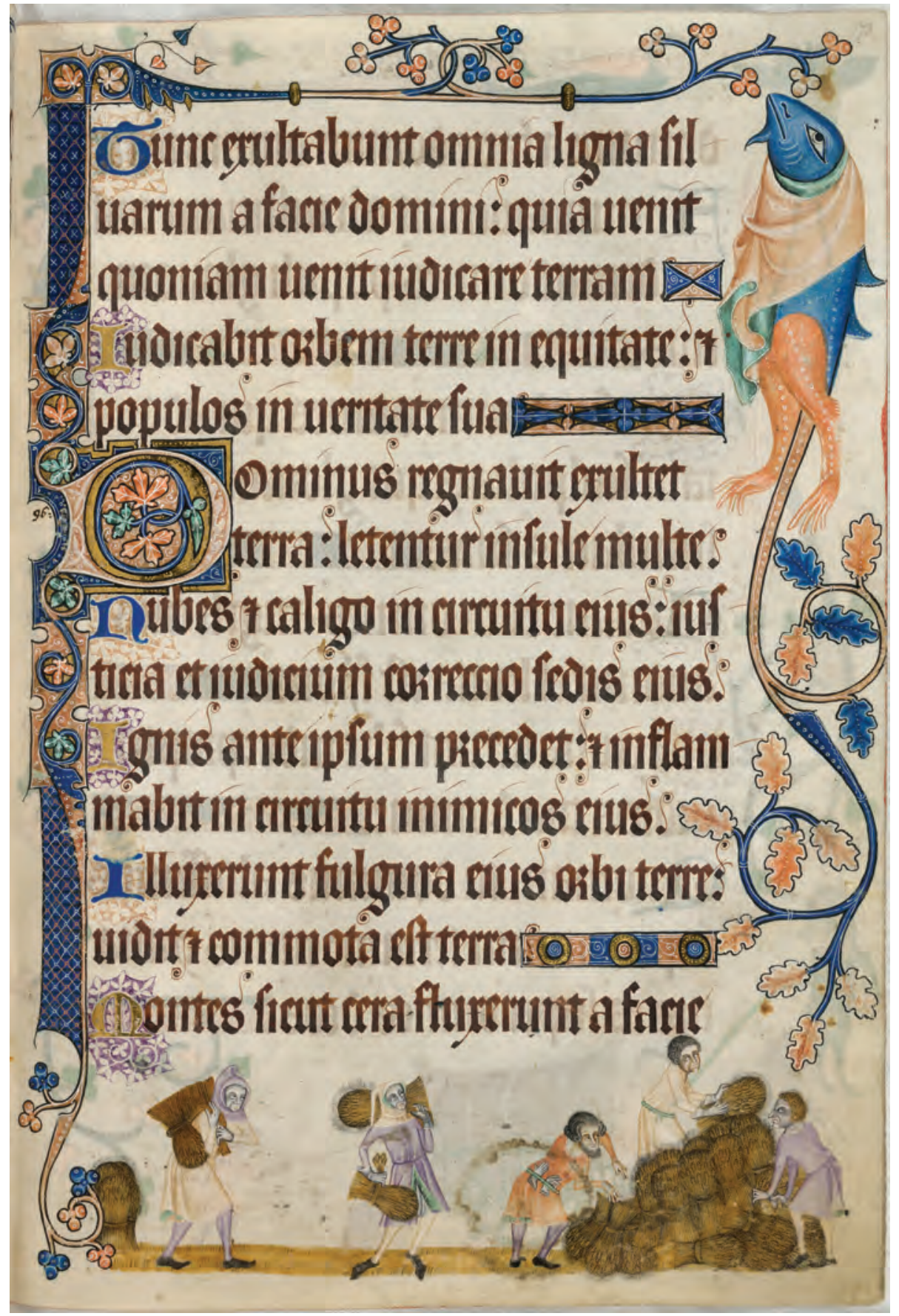

Plate 7. Stacking sheaves. (C) The British Library Board, MS Additional 42130 (c. 1330-45), fol. 173r. 


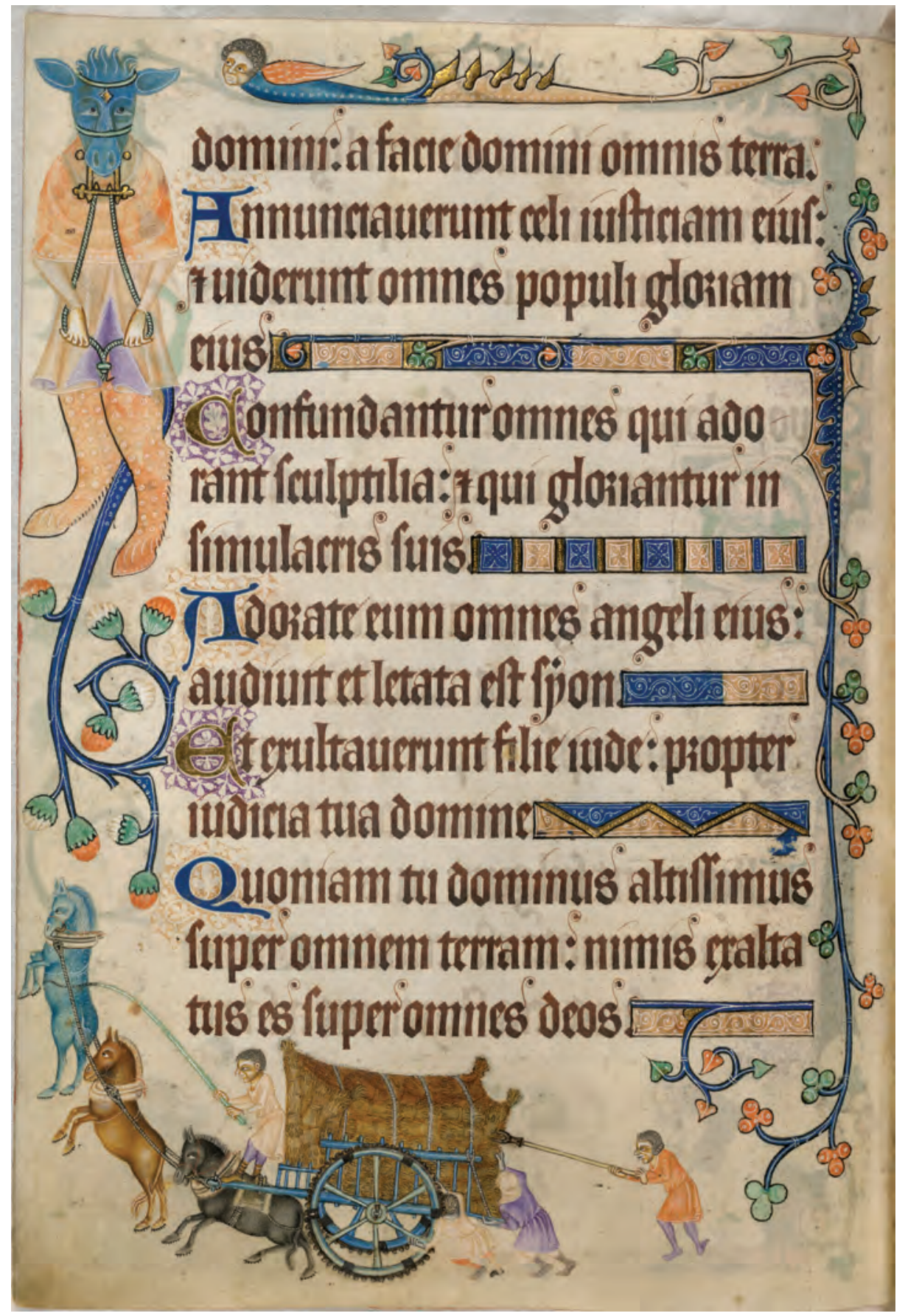

Plate 8. Cart full of sheaves. (C) The British Library Board, MS Additional 42130 (c. 1330-45), fol. $173 \mathrm{v}$. 


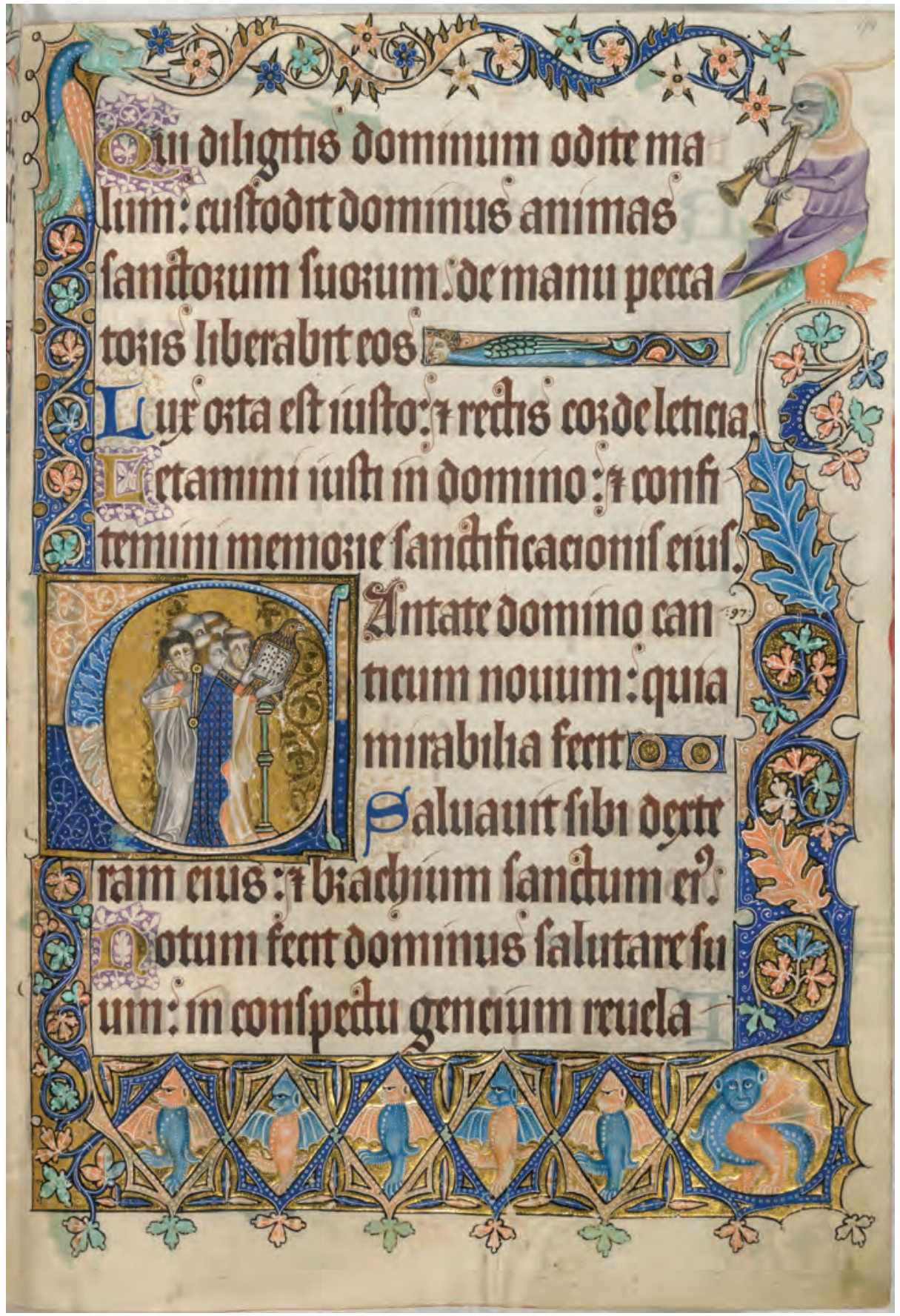

Plate 9. Clerics at a lectern. (C) The British Library Board, MS Additional 42130 (c. 1330-45), fol. $174 \mathrm{r}$. 




\title{
Working the Land, Working the Spirit
}

\author{
Agrarian Metaphor and Spiritual Community
}

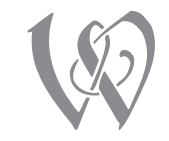

hen Langland builds Holy Church at the end of Piers Plowman, he turns to agrarian models - the cart of Christendom, the Barn of Unity-and in doing so, he taps into a well-established tradition of linking the work of the spirit with the work of the land. Alongside Chaucer's "treweswink[ing]" plowman and the famous series of agricultural images in the Luttrell Psalter, Langland's poem looms large in contemporary scholarship on the representation of labor in late medieval England. ${ }^{1}$ Agricultural labor provided a rich vocabulary for describing the spiritual lives of laypeople, not only as individual penitents but also as members of a broader Christian community working toward salvation. Beyond representing spirituality and penance as work, agricultural metaphor also had the potential to activate the particularly communal nature of that work. Through-

1. Chaucer, Canterbury Tales, fragment 1, line 531. See especially Aers, "Justice and Wage-Labor After the Black Death," 191-205; Camille, "Labouring for the Lord," 430-34; Frank, "'Hungry Gap, Crop Failure, and Famine” 227-43; Harwood, "The Plot of Piers Plowman and the Contradictions of Feudalism," 91-114; Knight, "Voice of Labour," 101-22; Middleton, "Acts of Vagrancy," 208-317. Robertson, Laborer's Two Bodies, 45-50. 
out the fourteenth century, agrarian metaphor offered an emblem of communal devotion and a means of conceptualizing the process of working toward salvation. In sermons from the early fourteenth-century Northern Homily Cycle, for example, manual labor is used to represent pastoral care, penance, and Christian charity. The famous sequence of agrarian images in the Luttrell Psalter, much more than a pictorial record of everyday farm labor, works to represent the Luttrell household-from plowman and reaper to chaplain and lord-as a coherent spiritual community. And in Piers Plowman, the controversial pardon in passus 6 is a harvest-sharing contract that looks to the language of village bylaws to imagine a diverse spiritual community founded on charity and neighborliness.

\section{Preacher-Plowmen in the Northern Homily Cycle}

Both the Luttrell Psalter and Piers Plowman are part of a broader discourse of spiritualized agricultural metaphor with biblical and liturgical roots. ${ }^{2}$ In the Lenten sermons from the earliest version of the Northern Homily Cycle (c. 1295-1306), for example, priests are represented as weeders and sowers who cultivate good, spiritually sound laypeople. During the broad penitential season that stretches from the day after Epiphany to the start of Holy Week, pastoral care takes the form of preparing the ground for the planting season. God himself is the husbandman in charge, and he sends his "sarmouneres"his sermoners-into the fields to "clense man of gastli wede [ghastly weeds]," to "snib" or prune him of his "misdedes," and to sow good seeds that will yield fruit in the form of charity and penance. ${ }^{3}$ This work is mapped onto the hours of the liturgical day: the earliest laborers arrive "about undrone"-or tierce, the third canonical hour-and represent Christ's apostles, while the "gode clerk[s]" Augustine, Bernard, and Gregory arrive "aboute middaye and about none." ${ }^{4}$ These Patristic fathers are diggers and reapers who work with holy writ:

2. On the long Christian tradition of the metaphorical plowman, see especially Barney, "Plowshare of the Tongue," 261-93; Kirk, "Langland's Plowman," 1-21.

3. Northern Homily Cycle, 69 (lines 42-48). The collection circulated widely in the first half of the fourteenth century and remained popular into the late fourteenth and fifteenth centuries, when it was substantially expanded in two different recensions. The first of these two expansions survives in the Vernon and Simeon manuscripts, while the second expansion appears in two fifteenth-century manuscripts. Northern Homily Cycle, 15. The latter manuscripts serve as the base for Nevanlinna's edition, Northern Homily Cycle: The Expanded Version.

4. Northern Homily Cycle, 85 (lines 93, 99, 97). "Undrone" refers to the midmorning liturgical hour; see MED, "undern," n., 1b" "Eccl. (a) The third canonical hour, 9 a.m.; daies; (b) the service of undern, tierce." See also Harper, Forms and Orders of Western Liturgy, 46-47. 
Thai ripid the rote of Hali Writte,

And to Cristen folk undid it;

When thai kende us what boke wald saye,

In gude vyneyard grubbid thaie. ${ }^{5}$

They reaped the roots of holy writ and untangled it for Christian people.

When they taught us what the book said, they worked in God's vineyard.

In the process of grubbing in God's field, these clerks provide lay access to scripture through commentary and exegesis. In a later version of this sermon, a verb change adds a sacramental dimension to these laborer-preachers; they have been "ordand" by God the husbandman to till man's soul-to make it "abill vnto his will" - with their pastoral labors. ${ }^{6}$ Lay penitents, too, are figured as workers, and their baptism in the church signals a kind of labor contract with God: "Criste callid us to do his werk, / When we atte fontestane [font stone] toke his merk." In the same way that "werkemen" such as prophets and exegetes are called into the vineyard, lay penitents are called into the parish church to be baptized at the font. ${ }^{8}$ The sermon's equation of manual labor with spiritual labor is further underscored in the sermon's repeated rhyming of "kirk" and "wirk."

The long Lenten period leading up to Easter coincided roughly with the spring growing season. The preparation of the land began in February and March, when the fields were manured and then plowed. Sowing came next, followed by harrowing. As Homans observed decades ago, the grains grown at this time of year were known as the semen quadragesimale, or "lenten tilth." The traditional association of agricultural metaphor with preaching and penance was further reinforced by the canonically prescribed readings for Septuagesima, the ninth Sunday before Easter, which always included Matthew's parables of the Vineyard and the Sower. ${ }^{11}$ The parallels between agricultural

5. Northern Homily Cycle, 85 (lines 103-6).

6. Northern Homily Cycle: The Expanded Version, 2:11 (lines 5812-14).

7. Northern Homily Cycle, 90 (lines 335-36).

8. Ibid., 85 (line 90).

9. Ibid., 85 (lines 89-90), 88 (lines 225-26); Northern Homily Cycle: The Expanded Version, 2:10-15 (lines 5781-82, 5931-32). The pairing of "wirk" and "irk" illustrates the contrast between productive labor and idle sin: "Parfor alway war gude to wirk / In Goddes wine-zerd, and be noght irk [unwilling, reluctant], / For he pat wirkes gude werk till end, / Withouten wage he sall noght wend." Ibid., 2:13 (lines 5877-80). See also Northern Homily Cycle 87 (lines 171-74).

10. Homans, English Villagers, 364. For a description of the agricultural year, from the spring growing season to the summer harvest, see Bennett, Life on the English Manor, 79-85.

11. As Raschko notes, in such a liturgical context, Middle English sermonists used parables about labor to "encourag[e] spiritual work through penitential disciplines." "Lollard Sermons," 
and penitential labor are striking: just as farmers cleared the land in order to have it sown with seed by the end of April, laypeople were expected to make confession and clear themselves of sin before receiving communion on Easter Sunday. Medieval sermonists took full advantage of this resonance by yoking together agriculture, penance, and the priesthood; in the Northern Homily Cycle, "sarmouneres" rake their parishioners clean of sin in order to convert their souls into smooth, tillable earth that will receive and nurture the good seed of God. ${ }^{12}$

\section{Manual and Liturgical Labor in the Luttrell Psalter}

In the Northern Homily Cycle, agrarian metaphor illustrates the relationship between God, a diligent priesthood, and the salvation-seeking laypeople in their care. A few decades later in the Luttrell Psalter, agrarian metaphor illustrates the relationship between an earthly manorial lord and the members of his household. Planned and produced between 1330 and $1345,{ }^{13}$ the Luttrell Psalter is most widely known for its images of agricultural labor: across eight consecutive folio pages, peasants in colorful dress work the land in chronological harvest order, from plowing to carting (plates 1-9). The series is famous for its accuracy and its meticulous attention to detail, but it offers far more than a visual inventory of late medieval agricultural practice. In bringing together the daily work of laboring in the fields with the daily work of reading through the psalms, the Luttrell Psalter treats manual labor as spiritual enterprise. The scenes of agricultural labor that adorn the manuscript's margins have been paired with images of liturgical performance-a combination that bolsters the manuscript's endeavor not only to equate manual labor with spiritual labor but also to represent the diverse ranks of Sir Geoffrey Luttrell's extended household as a unified Christian community.

178. Gayk has recently explored the use of agricultural imagery in Lollard Septuagesima sermons contemporaneous with Piers Plowman in "As Plouzmen Han Preued," 43-65; see also Cole's discussion of Septuagesima sermons in "Trifunctionality and the Tree of Charity," 4-5. On the place of parables in the medieval liturgy more generally, see Wailes, Medieval Allegories of Jesus' Parables, 5-7.

12. Northern Homily Cycle, 69 (line 42).

13. Brown, Luttrell Psalter: A Facsimile, 4. Sandler posits a date of c. 1325-30 based on stylistic affinities with other contemporary manuscripts, including the Douai Psalter. Gothic Manuscripts, 2:119-20. Given the book's omission from Sir Geoffrey's will, Emmerson and Goldberg have argued that the manuscript was incomplete in 1345 when the will was made, and that it "did not actually belong to Sir Geoffrey" because it was, "save perhaps for the customary advance, unpaid for." "Lordship and Labour in the Luttrell Psalter," 48. 
The manuscript is in many ways a vehicle for the self-display of its patron, Sir Geoffrey Luttrell. ${ }^{14}$ The famous equestrian portrait of Sir Geoffrey appears between psalms 108 and 109, just before a miniature of God and King David; the visual proliferation of lords across this two-page spread, coupled with the repetition of the word dominus, marks the psalter's most explicit statement of lordship. ${ }^{15}$ A more subdued and austere Sir Geoffrey appears at the bottom of folio 208r (fig. 5) in a dining scene that bears a striking resemblance to the depiction of the Last Supper that appears on folio 90v. With a chalice in his right hand, Sir Geoffrey sits in the position typically occupied by Christ, and the silver plate before him, embossed with a Greek cross, further reinforces the connection. ${ }^{16}$ The image depicts not only Sir Geoffrey's immediate family but also members of his extended household - servants, a steward, and a pair of Dominican friars-a spiritual assembly also evoked in Sir Geoffrey's will, in which he makes bequests to his chamberlains, confessor, porter, cooks, and butler, as well as five godsons, three of whom were members of his kitchen staff. ${ }^{17}$ In this visual transformation from decorated knight to pious and wan patriarch at the family dinner table, Sir Geoffrey trades secular for spiritual heraldry, his emblazoned shield for a sacramental chalice. More than a display of Sir Geoffrey's power and prestige, the scene ultimately imagines his broader household as a unified spiritual community whose members all work toward a common salvific goal. At the end of harvest, material labor and wealth are subsumed as Sir Geoffrey and his household come together-on the manuscript page, at least-to share a sacramental meal.

This spiritual agenda begins in the farming sequence. Although the farming and feasting sequences are separated by more than thirty folios, both have

14. On the manuscript's discourses of lordship, see especially Emmerson and Goldberg, "Lordship and Labour," 43-63; Camille, "Labouring for the Lord," 439-45; Marks, "Sir Geoffrey Luttrell and Some Companions," 346-48, 351.

15. This visual juxtaposition has been made possible by codicological engineering: the quire ending with the equestrian portrait contains only ten folios, while all other quire gatherings in the manuscript contain twelve. On this issue, see Camille, Mirror in Parchment, 50; Marks, "Sir Geoffrey Luttrell," 351. Backhouse notes further that "the large initial on the facing page, introducing Psalm 109, is the only initial in the book after the first which does not appear in the position on the page dictated by the run of the text. Instead, the miniature intervenes." Luttrell Psalter, 57.

16. As Emmerson and Goldberg note, the Greek cross resembles "the traditional sign on the host." "Lordship and Labour," 53. For other examples from the first half of the fourteenth century, see Sandler, Psalter of Robert de Lisle 57, plate 12; Brown, Holkham Bible Picture Book, fol. $28 \mathrm{r}$.

17. Camille has even speculated that individual people represented in the kitchen scenes correspond to actual members of the Luttrell household; the man stirring a pot of stew on f.207r., for example, is "probably Geoffrey's Cook, William le Ku." Mirror in Parchment, 317, and see also 82-83. For a transcription of Sir Geoffrey's will, see Millar, Luttrell Psalter, 53. 


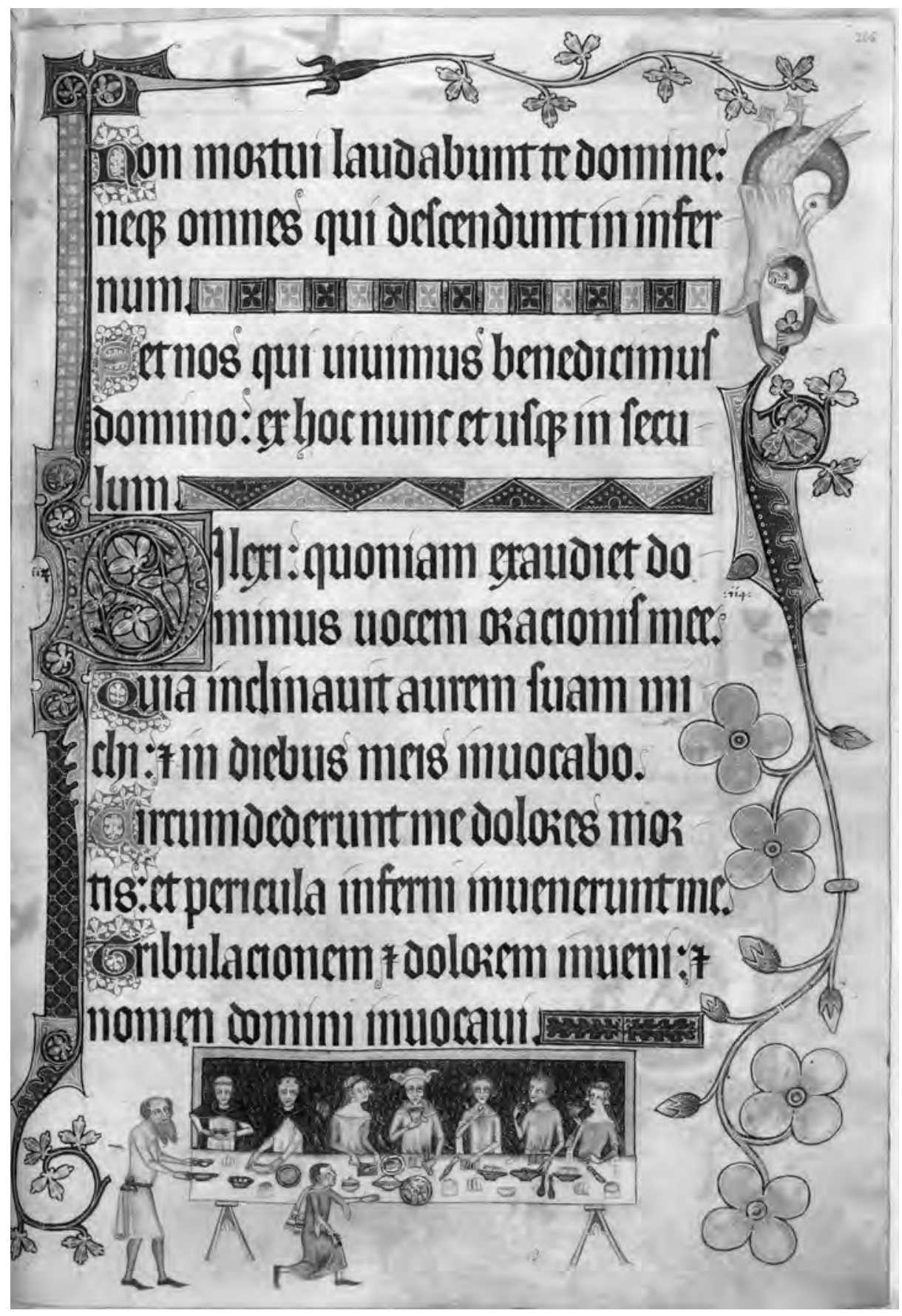

Figure 5. The Luttrell household at dinner. () The British Library Board, MS Additional 42130 (c. 1330-45), fol. 208r. 
been attributed to the psalter's fourth hand ${ }^{18}$ and are linked visually in terms of reading experience. ${ }^{19}$ In the farming sequence, for example, laborers work the land from left to right, their motion reinforced by the dark birds (plates 2-3) that make their way in the same direction across the facing pages. The left-to-right pattern is abruptly reversed on folio $173 \mathrm{v}$ (plate 8 ), where a cart piled high with densely packed sheaves travels from right to left and up the border of the manuscript page. The end of the farming sequence clearly anticipates the feasting sequence-the work of the field laborers puts food on the lord's table. ${ }^{20}$ Although images of productive harvest and heraldic splendor feature prominently in both sequences, the dominant theme engineered on these pages is one of labor as devotion. Grain sales may well have supported the gentle lifestyle of the Luttrells, but the psalter incorporates Sir Geoffrey into a wider program of imagery that equates work, both agricultural and liturgical, with worship. In this light, the heavy-laden cart anticipates not only the meal during which the family will reap the benefits of this productive harvest but also the harvest of the Last Judgment.

When treating the Luttrell Psalter's agricultural imagery, scholars often remark on the artist's intricate knowledge of agricultural equipment and practice. Camille has suggested, for example, that the left-to-right motion of the plow reflects the artist's concern with making a display of the plow's moldboard, which would not be visible if the artist had depicted the opposite side of the plow (plate 1). ${ }^{21}$ Questions of mechanical accuracy aside, however, such a detail also works more figuratively to evoke the traditional association of agricultural labor with the work of priests and exegetes. Sir Geoffrey's plowman recalls the "sarmouneres" of the Northern Homily Cycle who clear away the sinful weeds that clutter the tillable soul of man. The plowing image and

18. The so-called "Luttrell Master" oversaw the decoration of folios 145r-214v. See Camille, Mirror in Parchment, 326-29; Brown, Luttrell Psalter: A Facsimile, 23-25.

19. By this I refer not only to the experience of reading the psalms but also to the sequential reading of the bas-de-page imagery, an impulse sustained in both sets of images across facingpage spreads and through turning the leaves. On "modes of marginal composition" and the practice of reading marginalia from left to right as sequential narrative, see Sandler, "Study of Marginal Imagery," 13.

20. Camille associates the densely packed cart with a profitable, surplus-bearing harvest and suggests that "one of the products of this surplus on Geoffrey's estate was the Psalter itself." Mirror in Parchment, 200.

21. The moldboard, the part of the plow that lifts and turns the soil, "was usually built on the right-hand side of the plough so as always to turn the soil over to the right and create a furrow. It was because of this standard directional method of ploughing," Camille concludes, "that the artist has painted the group moving from left to right so that all the components are fully visible-if it were the other way round, the mould-board would be hidden." "Labouring for the Lord," 427. See also Langdon's description of moldboard plows in "Agricultural Equipment," 88-89. 
the sequence that it inaugurates also direct attention to the psalms that they accompany. ${ }^{22}$ Psalm 94 emphasizes God's creation of the earth: "In his hands are the depths of the earth; the heights of the mountains are his also. The sea is his, for he made it; and the dry land, which his hands have formed." ${ }^{23}$ The earthy concentration resumes in Psalm 95, which opens with a call to collective worship: "O sing to the Lord a new song; sing to the Lord all the earth." ${ }^{24}$

The artist makes the link between manual and spiritual labor even more explicit by pairing the bas-de-page agricultural scenes with historiated initials that depict images of liturgical performance. ${ }^{25}$ At the beginning of Psalm 95, just above the scene of clod-breaking, three open-mouthed clerics sing from a scroll (plate 4). And at the start of Psalm 97, across the page opening from the cart full of sheaves, we find another group of clerics, singing this time from a book propped open on a lectern (plate 9). Beyond dramatizing the psalms that they accompany-both psalms begin with Cantate domino canticum novum [Sing to the Lord a new song] — these images align the work of the cleric with the work of the land laborer. The two forms of labor are already elided, of course, in the psalm text itself, in which "all the earth" is called together in song. On folio $171 \mathrm{v}$, the clerics take up their liturgical music scroll, the clod breakers their mallets. On folio 174r, a second group of singing clerics emphasizes the cyclical nature of both land labor and the liturgy. They appear directly across from the cart of sheaves which, in moving from right to left, signals not only the culmination of the farming sequence and the close of a successful harvest but the turning of seasons: after the harvest, the land will be cleared and prepared for a new season and a fresh crop. The end of harvest is celebrated with song: "O sing to the Lord a new song, for he has done marvelous things." ${ }^{\text {"6 }}$ While the text of Psalm 97 can be seen as celebrat-

22. On "word visualization" and the close relationship between word and image in the Luttrell Psalter, see especially Sandler, "Word in the Text and the Image in the Margin," 87-99; Camille, "Labouring for the Lord," 422. For a recent survey of theories of marginality, with several pages devoted to the Luttrell Psalter, see Smith, "Margin," 29-44; see also Sandler, "Study of Marginal Imagery," 37-40.

23. Ps. $94: 4-5$ (NRSV 95:5).

24. Ps. 95:1 (NRSV 96:1).

25. Images of clerics gathered at lecterns accompany Psalm 97 in numerous fourteenthcentury psalters; see, for example, Sandler, Gothic Manuscripts, figs. 288, 318, 338. Zieman maintains that "despite the convention of singing from memory, the most iconic representation of liturgical singing was one that stressed the presence of the Book as well as communal performance: several clerics, mouths open, gathered around a single book or scroll." Singing the New Song, 43. According to MacKinnon, the motif is standard in psalter iconography from the thirteenth century on. "Musical Instruments in Medieval Psalm Commentaries and Psalters," 17. On the traditional association of monastic singing and manual labor, see Boynton, "Work and Play in Sacred Music," 57-61.

26. Ps. 97:1 (NRSV 98:1). 
ing the harvest of the previous page-a reading bolstered in the image of the clerics, one of whom directs his gaze away from the lectern and toward the cart-text and image also work to link the agricultural year with the liturgical year. Not unlike the labors of the land, psalmody itself was also cyclical: the 150 psalms comprising the psalter were sung in full over the course of the liturgical week, and the recitation continued unceasingly throughout the year. The juxtaposition of this otherwise conventional image with the last in a series of agricultural scenes extends the association of seasonal labor with the cyclical performance of the psalms.

Sir Geoffrey plays an important role in this effort. In addition to his appearance in the equestrian and feasting images, his shield (azure a bend between six martlets argent) appears in the top right-hand corner of the twopage spread that depicts not only sowing and harrowing but also the beginning of Psalm 94, which invites the reader to "come into [the Lord's] presence with thanksgiving, and make a joyful noise to him with songs of praise [psalmis]" (plate 3). ${ }^{27}$ Sir Geoffrey's lordship over the land comes into sharp focus alongside the fourth and fifth verses of Psalm 94: "In his hand are the deep places of the earth: the strength of the hills is his also. The sea is his, and he made it: and the dry land, which his hands have formed." ${ }^{28}$ The laborers, too, are his: "He is our God," the psalm proclaims, "and we are the people of his pasture and the sheep of his hand." ${ }^{29}$ A repetition of possessive pronouns serves to align Sir Geoffrey's temporal lordship over the land being sown and harrowed with God's eternal lordship over the earth, inviting both worship of the Lord God and worship of the lord Geoffrey Luttrell.

The manuscript encourages commemorative worship in particular. Although scholars disagree about the book's intended use, I follow Emmerson and Goldberg in suspecting that the Luttrell Psalter was designed for general liturgical use, including the weekly recitation of the 150 psalms as part of the daily performance of the Divine Office. The book's dimensions and layout suggest that it was designed to accommodate multiple readers at a lectern. Its liturgical function is bolstered, moreover, by the fact that it lacks the vernacular prayers and devotional texts that one might find in a book designed for more personal use. ${ }^{30}$ The Luttrell Psalter may well have been

27. "Praeoccupemus faciem eius in confessione, et in psalmis iubilemus ei." Ps. 94:2 (NRSV 95:2).

28. "Quia in manu eius sunt fines terrae et altitudines montium ipsius sunt. Quoniam ipsius est mare et ipse fecit illud: et siccam manus eius formaverunt." Ps. 94:4-5 (NRSV 95:4-5).

29. "Quia ipse est Deus noster et nos populus pascuae eius et oves manus eius." Ps. 94:7 (NRSV 95:7).

30. See Emmerson and Goldberg, "Lordship and Labour," 50. On the contents and arrangement of medieval psalters, see Harper, Forms and Orders of Western Liturgy, 67-72; Hughes, 
intended to provide the liturgy for Sir Geoffrey's own commemoration in the chantry chapel maintained by the Luttrell family in their parish church of St. Andrew-he left a substantial sum of money for five years' worth of Masses after his death. ${ }^{31}$ The manuscript's inclusion of the full Office of the Dead, complete with music notation, would certainly facilitate such a function. ${ }^{32}$ Sir Geoffrey also provided for clerics reading from a psalter on the day of his burial. ${ }^{33}$ Although these details would seem to confirm a memorial purpose for the Luttrell Psalter, the manuscript itself never appears in Sir Geoffrey's will, a conspicuous omission that suggests that it was unfinished in 1345 at the time of his death. Whether or not the Luttrell Psalter was designed for use in the Luttrell family chantry chapel, it seems clear that Sir Geoffrey wanted to maintain a presence in the ritual life of his parish church. As others have noted, his lavish tomb originally occupied the northeast bay of the chancel crossing, where it probably served as an Easter sepulchre, visited and adored by the entire parish during Holy Week. It may also have functioned throughout the liturgical year as a storage space for the consecrated host, making Sir Geoffrey's tomb a major player not only in the annual celebration of Christ's death and resurrection but in the weekly celebration of the Eucharist. ${ }^{34}$

Tomb, chantry, and psalter all work to remember the life and lordship of Sir Geoffrey, even aligning his commemoration with that of Christ. But the Luttrell Psalter also enables this absent lord to maintain an active presence in the everyday worship of his parish church. Indeed, the manuscript inserts Sir Geoffrey into the daily liturgy by depicting his heraldic shield alongside Psalm 94, the most ubiquitous of psalms: the standard invitatory for matins, it was performed every single day at the start of the Divine Office. ${ }^{35}$ I have argued that the manuscript links manual labor with liturgical performance, all under the gaze of Sir Geoffrey, and that in doing so it represents the extended Luttrell household as a unified spiritual enterprise. This effort is at its most

Medieval Manuscripts for Mass and Office, 224-37; Wright, "Introducing the Medieval Psalter," $1-11$.

31. "Item do lego XX capellanis ad celebrandum pro anima mea per V annos proxime sequentes post decessum meum in ecclesia de Irnham ubi corpus meum requiescat Quincentas marcas sterlingorum, videlicet quolibet anno C marcas.” Millar, Luttrell Psalter, 52. The chantry chapel was established in 1303 by Sir Geoffrey's grand uncle, Robert Luttrell, who served as rector of the parish church of St. Andrew's, Irnham, from 1262 until his death in 1315; see Abbott, History of the Parishes of Irnham and Corby, 36-37, 60.

32. Emmerson and Goldberg, "Lordship and Labour," 50.

33. "Item do lego clericis psalteria dicentibus xl solidos." Millar, Luttrell Psalter, 52.

34. Emmerson and Goldberg, citing the work of Pamela Sheingorn and Veronica Sekules, posit that the "tomb-cum-sacrament-shrine" may have "served to house not just the mortal remains of the lord of Irnham, but the living body of Christ. Commemoration of the dead lord was combined with commemoration of the living Deity." "Lordship and Labour," 52.

35. Hughes, Medieval Manuscripts for Mass and Office, 52. 
explicit in the everyday use of the psalter and in the daily recitation of Psalm 94. In one ritual moment, all members of the extended Luttrell household, living and dead, come together in an act of worship. As the laborers head into the fields at dawn to begin the work of the day, clerics begin the Divine Office and settle in to the daily rhythm of psalm recitation. And from the grave, Sir Geoffrey himself issues the daily call to worship, uniting the parish of St. Andrew in collective psalmody.

\section{Half-Acre Bylaws: Harvest-Sharing in Piers Plowman}

The Luttrell Psalter's blend of agricultural and clerical imagery applies the biblical tradition of the preacher-plowman to the late medieval manor and puts patron Sir Geoffrey at the center of a community in which collective labor in the fields represents the communal work of salvation. The psalter's plowman and ox-driven plow mobilize biblical agricultural metaphors that appear elsewhere in contemporary literature and art from the first half of the fourteenth century, particularly the Northern Homily Cycle, but the connection between the work of the land and the work of the spirit is even more explicit in the later fourteenth-century poem Piers Plowman. Indeed, the image of the Luttrell plowman has become something of an icon for Piers and the spiritual journey that begins on his unplowed half-acre of land. ${ }^{36}$ Langland's poem is concerned not just with the collective nature of manual and spiritual labor, however, but also with the contingent relationship between good communal work and spiritual salvation. As Piers's pardon clearly stipulates, those who do well will end well. I examine the language and form of the pardon in the context of village labor regulation in order to argue that Piers's pardon functions as a kind of labor contract designed to regulate spiritual work on the half-acre: only those who do good work can number themselves among the collective saved at Judgment.

Studies of the pardon have tended to focus either on the moment of its tearing or on the question of whether or not the pardon is, indeed, a pardon. ${ }^{37}$ In arguing that the pardon is a spiritualized labor contract, I begin by

36. A cropped image of the Luttrell plowman without his evangelist-oxen appears on the cover of the Penguin edition. Langland, Piers the Ploughman, ed. Goodridge. The cover of a recent essay collection wraps the full plowing scene around the cover in such a way that that the oxen appear on the front of the book, the plowman and his plow on the back. Hewett-Smith, ed., William Langland's "Piers Plowman": A Book of Essays. For a fascinating survey of the use of reproductions from the psalter since 1794, see Camille, Mirror in Parchment, 25-43.

37. For Baker, the tearing of the pardon marks Piers's conversion from plowman to penitent: "From Plowing to Penitence," 716-17; see also Godden, "Plowmen and Hermits," 131-34. 
examining its basic formula-those who do well will end well, and those who do badly will end badly-within a broader context of liturgical practice and lay instruction. Because the pardon provides access to collective salvation in reward for good work, it effectively extends the contractual agreement that every medieval Christian made at baptism. Baptized Christians agreed to do God's work, and those who made good on that agreement over the course of a lifetime by, for example, loving their neighbors and fulfilling the Seven Corporal Works of Mercy would ultimately be rewarded with salvation. In addition to rooting the pardon and its promise of salvation in the liturgy and teachings of the church, however, Langland also emphasizes the distinctly collective nature of lay spirituality by giving the pardon an agricultural framework that associates communal spiritual work with the tightly controlled labor of the land. As Minnis has recently suggested, Piers's pardon is "a communal or 'group' pardon," and the fair field of folk an "allegorized fraternity" who are eligible to take advantage of the kind of collective indulgence that fourteenth-century confraternities were offering to their members. ${ }^{38}$ But the collectivity of Piers's pardon is also distinctly agricultural. Langland combines the theology of Last Judgment with the prescriptive and regulatory language of the village bylaw - that is, the rules of harvest found in manorial court rolls. He does so, I argue, in order to emphasize the collective spiritual rewards of communal labor.

\section{The Liturgy and Gospel of Pardon: Creeds, Baptism, and the Works of Mercy}

The contractual terms of the pardon are explicitly stated in passus 7 , when Grace gives Piers a pardon "for hym and for his heires for everemoore after." ${ }^{39}$

A review of early interpretations of the Pardon scene appears in Frank, "Piers Plowman" and the Scheme of Salvation, 28-29; see also his "Pardon Scene in Piers Plowman," 317-31; Woolf, "Tearing of the Pardon," 50-75; Schroeder, "Piers Plowman: The Tearing of the Pardon," 8-18; Simpson, "Piers Plowman": An Introduction, 71-75. Lawler has argued that various iterations of the pardon appear throughout the poem and are part of a sustained and "recursive" endeavor to explore various definitions of "Dowel" as a form of penance. "Pardon Formula in Piers Plowman," 135-40. Alastair J. Minnis has warned against the "long-established tendency in Langland studies to keep literal/historical indulgences and Piers' special pardon well apart." The best way to understand Piers's pardon, Minnis suggests, is through an analysis of the literal and historical "valence" of the numerous vehicles Langland deploys in constructing it. "Piers's Protean Pardon," 239, 223. On Piers's pardon and late medieval documentary practice, see Steiner, Documentary Culture, 93-142, 155-57.

38. Minnis, "Piers' Protean Pardon," 227.

39. Langland, Vision of Piers Plowman: A Critical Edition of the B-Text, ed. Schmidt, 7.4. 
A priest recites the pardon's two lines- "Et qui bona egerunt ibunt in vitam eternam; / Qui vero mala, in ignem eternum" - and concludes that the pardon is, in fact, no pardon at all. ${ }^{40}$ "I kan no pardon fynde," the priest pronounces, translating the Latin into English, "But 'Do wel and have wel, and God shal have thi soule,' / And 'Do yvel and have yvel."' ${ }^{41}$ The Latin text of the pardon corresponds with the forty-third clause of the Athanasian Creed, which was recited daily at Prime. ${ }^{42}$ Known popularly as the Quicunque vult, a title taken from the Creed's opening words, "Quicunque vult salvus esse," or "whosoever wishes to be saved," the Creed explicates the doctrines of Trinity and Incarnation. The Et qui bona clause appears in the Creed's closing statement on the theology of Last Judgment:

Who suffered for our salvation, descended to hell, rose from the dead, ascended to heaven, sat down at the Father's right hand whence he will come to judge living and dead: at whose coming all men will rise again with their bodies, and will render an account of their deeds; and those who have behaved well will go to eternal life, those who have behaved badly to eternal fire. This is the Catholic faith. Unless a man believes it faithfully and steadfastly, he will not be able to be saved. ${ }^{43}$

Whoever wishes to be saved, the Creed concludes, must live a life of good works which, when fully accounted at the end of days, will be rewarded with a place in heaven. According to both the Creed and Piers's pardon, those who have behaved well-qui bona egerunt-will be saved, while those who behaved badly_qui mala [egerunt] —will go to hell. The pardon and its promise of salvation in reward for good work have important implications for the poem's representation of spiritualized agricultural labor.

Beyond the scene's resonance with the Athanasian Creed, Piers's pardon is part of the well-established tradition of spiritualized agrarian metaphor found

Unless otherwise indicated, all Piers Plowman quotations are taken from this edition of the Btext, hereafter referred to as Langland, Piers Plowman.

40. Ibid., 7.110a. "Whosoever desires to be saved must above all things hold the Catholic faith." Kelly, Athanasian Creed, 17. The Latin text of the Creed appears in parallel with an English translation at 17-20.

41. Langland, Piers Plowman, 7.111-14.

42. Harper, Forms and Orders of Western Liturgy, 98-100, 312; Kelly, Athanasian Creed, 44.

43. "Qui passus est pro salute nostra, descendit ad inferna, surrexit a mortuis, ascendit ad caelos, sedit ad dexteram Patris, inde venturus iudicare vivos et mortuos: ad cuius adventum omnes homines resurgere habent cum corporibus suis et reddituri sunt de factis propriis rationem; et qui bona egerunt ibunt in vitam aeternam, qui mala in ignem aeternum. Haec est fides catholica: quam nisi quis fideliter firmiterque crediderit, salvus esse non poterit." Kelly, Athanasian Creed, 20. 
in biblical and homiletic texts, and I want to return to a passage from the Northern Homily Cycle that helps illustrate the contractual nature of Piers's pardon. In the sermon for Septuagesima Sunday, lay penitents are figured as workers, and their baptism in the church signals a kind of labor contract:

For Criste callid us to do his werk

When we atte fontestane toke his merk.

His merk beres ilk a Cristen man

That Cristendome hase on him tane $[$ taken $] .{ }^{44}$

In the same way that "werkemen," such as prophets, exegetes, and priests, are called into the fields, lay penitents are called into the parish church to be baptized at the font. ${ }^{45}$ The liturgical ceremony of baptism signals a layperson's entrance into the Christian community, and the Northern Homily Cycle poet represents it as initiation into a communal spiritual workforce: Christ presses "us" into service, he explains, when "we" approach the font at baptism. To enter the church - that is, to assume the "merk" of Christ through baptismis to begin a life of penance, and the poet foregrounds this association by rhyming "werk" with "merk." Throughout the Septuagesima sermon, spiritual activities-baptism and penance, for example-are closely aligned with tilling and harvest, and the vineyard represents both the church and its people; as the poet explains early on, "And be this vyneyard will he mene / The folk of Hali Kirk bedene [together]." ${ }^{46}$ In a late fourteenth-century revision of the sermon, the representation of spiritual practice as agricultural labor is further reinforced by the substitution of "tilth" for "folk." 47

In calling Christians into the fields, the author of the Northern Homily Cycle makes it clear that Christians must do God's "werk" in order to be saved, work that involved not only undergoing penance and avoiding sin but also living charitably and caring for others. In Matthew 25, when Jesus describes the separation of the sheep from the goats at the Last Judgment, he stipulates that only those who have lived charitably will be saved. ${ }^{48}$ Matthew 25 also outlines the Corporal Works of Mercy, the outward expressions of charity that featured so prominently in late medieval catechetical texts and penitential handbooks.

44. Northern Homily Cycle, 90 (lines 335-38).

45. Ibid., 85 (line 90).

46. Ibid., 85 (lines 83-84).

47. Northern Homily Cycle: The Expanded Version, 2:10 (line 5776).

48. "All the nations will be gathered before him, and he will separate the people one from another as a shepherd separates the sheep from the goats, and he will put the sheep at his right hand, and the goats at the left." Matt. 25:32-33. 
In addition to their appearance in instructional texts, the Corporal Works of Mercy were also a standard part of parish church iconography, often in juxtaposition with imagery related to the Seven Deadly Sins. As we have already seen in the west wall painting at the parish church of St. George in Trotton (fig. 4), the Corporal Works of Mercy appear as part of a more complex treatment of the Last Judgment: Christ appears in the middle, with the Seven Deadly Sins on one side and the Seven Works of Mercy on the other. ${ }^{49}$ Salvation at the end of days is contingent upon completing the Corporal Works; just as the Athanasian Creed stipulates that those who live well will end well, the iconography of Last Judgment teaches that those who feed the hungry and visit the sick will enjoy salvation.

The efficacy of the Corporal Works of Mercy is vividly dramatized in the York Cycle's Last Judgment Play, a rendering of Matthew 25 in which Jesus separates the saved from the damned. ${ }^{50}$ Addressing the saved, the figure of Jesus congratulates the "blessed children on [his] right hand" for having fulfilled the works:

When I was hungry, ye me fed;

To slake my thirst your heart was free;

When I was clotheless, ye me clad,

Ye would no sorrow upon me see.

In hard press when I was stead,

Of my pains ye had pity;

Full sick when I was brought in bed,

Kindly ye came to comfort me.

When I was ill and weariest

Ye harboured me full heartfully;

Full glad then were ye of your guest,

And plained my poverty piteously.

Belive ye brought me of the best

And made my bed full easily,

Therefore in heaven shall be your rest,

In joy and bliss to be me by. ${ }^{51}$

49. For further discussion of the Trotton painting, see chapter 3.

50. References to the performance of the York Cycle appear as early as 1376 and 1379, and the Mercers are connected with the Last Judgment play in the 1415 Ordo Paginarum. See Johnston and Dorrell, "York Mercers and their Pageant of Doomsday," 11.

51. York Mystery Plays, 277 (lines 285-300). 
These acts of charity, Jesus further clarifies, were completed when those in need "asked you help and had it soon." ${ }^{2}$ The damned, of course, failed to respond to the less fortunate: "Ye heard them not, your ears ye hid, / Your help to them was not at home." ${ }^{33}$ In the Mercers' Last Judgment play, salvation is entirely predicated on a penitential lifestyle that manifests outwardly in the performance of charitable acts. Jesus' first speech, delivered to the apostles, foregrounds this relationship between penance and redemption:

All tho that would them right repent

Should with you wend and winly [joyfully] wake;

And to your tales who took no tent

Should fare to fire with fiends black.

Of mercy now may nought be meant,

But, after working, wealth [prosperity] or wrake [destruction]. ${ }^{54}$

Those who repent will live in heaven alongside the apostles, while those who pay no attention to the principles laid out in Matthew's Gospel will end up in hell. In suggesting, moreover, that those who do well should count themselves among the saved, Jesus invokes the contractual spirit of the Athanasian Creed; mercy is doled out according to one's "working." Working here means doing well, but work is also linked with penance: those who work well are those who "right repent." Those who failed to listen to Jesus' pleas-those who ignored their even-Cristen and failed to perform charitable works-have accordingly achieved "wrake" rather than "wealth." 55 In the York Cycle, the relationship between good work and salvation relies on the same opposition of saved and damned formulated in the Gospel of Matthew and the Athanasian Creed.

\section{Regulating Labor on the Half-Acre}

In Piers Plowman, working well is associated with agricultural labor in particular. The framework of Piers's pardon is the agricultural year, and the cycle of labors he describes_-sowing, plowing, gleaning-were all performed

\footnotetext{
52. Ibid., 277 (line 311).

53. Ibid., 279 (lines 359-60).

54. Ibid., 274 (lines 195-200).

55. Boboc discusses the relationship between charitable work and salvation in the York Last Judgment play in "Lay Performances of Work and Salvation," 258-62. On the theme of labor in the York Crucifixion, see especially Sarah Beckwith, Signifying God, 65-70.
} 
collectively in the late medieval system of open-field farming. ${ }^{56}$ The labors of the agricultural year provide an analogy to the spiritual life of the Christian laity; in the same way that good farming yields a good harvest, doing the hard work of penance and charity will yield salvation.

The pardon's formula-those who have done good will enter heaven, and those who have done evil will enter hell-appears as early as the prologue, and its collective agrarian framework is spelled out well in advance of the tearing scene in passus $7 .{ }^{57}$ Spiritual pardon refers more broadly to a communal understanding of penance and charity that is ultimately made manifest in agricultural terms. Piers explains that he cannot lead the pilgrimage to truth until his field has been plowed: "I have an half acre to erie," he says; "Hadde I eryed this half acre and sowen it after, / I wolde wende with yow and the wey teche. ${ }^{58}$ Although plowing and pilgrimage are initially conceived in sequential terms, the distinction between the two activities gives way when Piers dresses like a farmer and calls himself a pilgrim: "I shal apparaille me [...] in pilgrymes wise," 59 he says, donning a set of patched leggings and trading his pilgrim bag for a sower's hanging seed basket. ${ }^{60}$ Rather than a chore that must be completed before the pilgrimage can begin, the everyday labor of plowing the half-acre is itself conceived as a spiritual journey, and this is neatly reinforced at 6.103 when Piers describes his "plowpote," the long-handled implement used to scrape dirt from a plow, as his "pikstaf." ${ }^{61}$ Manual labor is the way of the sheep at God's right hand, and those who help Piers will have the right to reap the spiritual fruits of their shared labor. "A busshel of bred corn brynge me therinne," Piers orders,

56. Homans, English Villagers, 70-76; Bennett, Life on the English Manor, 44-46; Ault, Open Field Farming, 21-30; idem, "Some Early Village By-Laws," 217-18; Dyer, "Piers Plowman and Plowmen," 162-63.

57. On the formula of the pardon as a structural principle for the poem's first two visions, see Lawler, "Pardon Formula in Piers Plowman," 135-36.

58. Langland, Piers Plowman, 6.4-6.

59. Ibid., 6.57 .

6o. "He caste on hise clothes, yclouted and hole, / Hise cokeres and his coffes for cold of hise nailes, / And heng his hoper at his hals in stede of a scryppe." Ibid., 6.59-61.

61. Ibid., 6.103. MED, "plough,” n., 1c, e: “ patil, a long-handled spade used to remove earth adhering to a plow, or to chop roots; bat, pot, staf, a stick or staff, prob. having the same function as a plough-patil." Minnis observes a "major semantic shift" in passus 7, "as the text moves from pilgrimage understood as a movement through time and space, through Treuthe's command not to set out on such a journey after all (which is where the allegorical pilgrimage-commutation comes in), to a master narrative based on the notion that life itself is a pilgrimage, and the half-acre its locus." "Piers' Protean Pardon," 233; see also Baker, "From Plowing to Penitence," 716-17. This passage was famously excised from the C-text revision. Crane, "Writing Lesson of 1381," 211; Justice, Writing and Rebellion, 233-37; Robertson, Laborer's Two Bodies, 45-50. 
For I wol sowe it myself, and sithenes [thereafter] wol I wende To pilgrymage as palmeres doon, pardon for to have.

And whoso helpeth me to erie [plow] or sowen here er I wende, Shal have leve, by Oure Lord, to lese [glean] here in hervest And make hym murie thermyd, maugree whoso bigrucche it [And make merry therewith, no matter who begrudges it]. ${ }^{62}$

Whoever helps with the plowing and sowing, Piers explains, will have the right to "lesen," or glean, the fruits of the harvest. This passage represents an iteration of the pardon formula, and the phrase "whoso helpeth" evokes the language of the Athanasian Creed.

Already in passus 6, then, Langland has translated spiritual salvation into fruitful harvest: those who help plow and sow are eligible to glean the fruits of their labor. When the pardon is first announced at the beginning of passus 7 , its contractual terms are steeped in agricultural language:

Treuthe herde telle herof, and to Piers sente

To taken his teme and tilien the erthe,

And purchaced hym a pardoun a pena et a culpa [from punishment and from guilt]

For hym and for hise heires [heirs] for everemoore after;

And bad hym holde hym at home and erien hise leyes [plow his land], And alle that holpen [help] hym to erye [plow], to sette [plant] or to sowe, Or any maner mestier [craft] that myghte Piers availe-

Pardon with Piers the Plowman Truthe hath ygraunted. ${ }^{63}$

Langland relies once again on a contractual "those who" formula: "All that holpen" have been "ygraunted" pardon with Piers. Building on his formulaic use of the Athanasian Creed, Langland reinforces the pardon's agricultural dimension by adding a statute that establishes Piers's coworkers as its perpetual beneficiaries. Grace's pardon is for Piers "and for his heires"-that is, his heirs or descendants. While this phrase is typically read as legitimizing legalese that lends the pardon authority as an ecclesiastical document, its agricultural pun has been ignored. ${ }^{64}$ The pardon is not only for Piers's

62. Langland, Piers Plowman, 6.63-67.

63. Ibid., 7.1-8.

64. Alford, for example, compares the phrase "for hym and for hise heires everemoore after" to the formulas that appear in bequests. "Piers Plowman": A Glossary of Legal Diction, 69-70. Bennett has described the phrase as "a legal formula" that "recalls formulas used in papal documents regarding those who contribute to the support of a church." Langland, Piers Plowman: The Prologue and Passus I-VII of the B Text, ed. Bennett, 216-17, n. 4. 
heirs but for his "eriers," or fellow plowmen: the pun reinforces the harvestsharing dimension of the pardon. ${ }^{65}$ This recasting of spiritual pardon as collective labor contract continues with the prescription that "Alle libbyng laborers that lyven with hir hondes [. . . / Haveth the same absolucion that sent was to Piers" (7.60-63).

Langland's "those who" formula works in passus 6 and 7 to establish the community of the saved on the half-acre: those who help with the harvest may reap its benefits. In constructing this community, Langland necessarily catalogs those who are not included-those who have no right to reap the benefits. While Piers promises to "fynden fode" for anyone who "lyve[s] in truthe," his pledge is immediately followed by a list of people who will not share in the harvest. "Alle kynne crafty men" will be rewarded, he says,

Save Jakke the Jogelour and Jonette of the Stuwes,

And Danyel the Dees-pleyere and Denote the Baude,

And Frere the Faitour [deceiver], and folk of his ordre,

And Robyn the Ribaudour [ribald], for hise rusty wordes.

Truthe tolde me ones and bad me telle it forther:

Deleantur de libro vivencium-I sholde noght dele with hem,

For Holy Chirche is hote [bidden], of hem no tithe to aske,

Quia cum iustis non scribantur.

Thei ben ascaped good aventure-now God hem amende! ${ }^{66}$

These people, Piers mandates, have been written out of the book of life: "Deleantur de libro vivencium [.. .] Quia cum iustis non scribantur." ${ }^{67}$ Jakke, Jonette, and Robyn have "ascaped good aventure," and Piers "sholde noght dele with hem." Piers's exclusion of Jakke and Jonette from the book of life also resonates with the rejection of the damned at the Last Judgment. Those who are condemned to hell can never be saved: "Quia in inferno nulla est redemptio" [For in hell there is no redemption] ${ }^{68}$ This Latin phrase appears in a debate about the Harrowing of Hell in passus 18 of the poem and is based on a nocturnal response in the Office of the Dead which, in addition to being performed at funerals and in chantry chapels, regularly appeared in psalters and even in books of hours, often accompanied by vivid illustrations

65. $M E D$, "erere," n.: "a plowman." $M E D$, “eren," v.1: "to plow or cultivate."

66. Langland, Piers Plowman, 6.70-78.

67. "Let them be blotted out of the book of the living; let them not be enrolled among the righteous." Ps. 68:29 (NRSV 69:28).

68. Langland, Piers Plowman, 18.149a. 
of penance, death, and burial. ${ }^{69}$ In the liturgy and iconography of the Last Judgment, some are saved, and some are damned. In order to articulate the spiritual community of the half-acre, then, Piers must also specify who gets excluded: sinners and wasters have no access to his pardon.

\section{Piers's Bylaws}

Exclusion is also one of the primary functions of village bylaws, the harvest regulations that, beginning in the late thirteenth century, appear in manorial records across England. ${ }^{70}$ The earliest bylaws and those from the fourteenth century are devoted to the regulation of harvest practices such as carting, encroachment, rights of pasture, and, above all, gleaning. ${ }^{71}$ The bylaws' approach to gleaning rights is particularly relevant to my treatment of the pardon scene because the gleaning workforce is explicitly defined in opposition to lists of banned persons and behaviors. During harvest, there was a job for everyone, at least in theory. In order to insure that the less able-bodied had work, however, harvest labor, especially gleaning, was highly controlled and regulated. This last stage of the harvest involved collecting the broken sheaves and stubble that had been left behind by reapers and binders. Slow work that did not require heavy tools or machinery, gleaning was a popular job for children, the elderly, and the infirm. But gleaning was also lucrative. As Ault has noted, "a gleaner could earn almost as much in a day as a reaper."72 "Even being caught and fined was worth the risk," Hanawalt adds, "because the fines were so low."73

In order to keep this sought-after job available for those who were not capable of doing more physically demanding wage labor, manorial officials

69. Gray, "Langland's Quotations from the Penitential Tradition," 58; and for further discussion of the illustration of the Office of the Dead, see Wieck, "Death Desired," 431-76. For the Office of the Dead in Middle English translation, see Prymer, or Lay Folks' Prayer Book, 52-78.

70. Thirsk notes that the "earliest case of regulated cropping" dates to c. 1156-57. "Common Fields," 23.

71. See especially the works of Ault: "Some Early Village By-Laws," 208-31; Open-Field Farming; "By-Laws of Gleaning," 210-17; "Open-Field Husbandry," 1-102; "Vill in Medieval England," 188-211. Ault emphasizes that bylaws sought, above all, to preserve community; they were not issued from the top down but rather "flow[ed] from the common interest of all the 'shareholders' of the farming community." Open-Field Farming, 226. Dyer warns against painting an overly idealized portrait of the medieval village; the preambles about common consent that appear in many bylaws should not be read at face value. "Power and Conflict," 30-31; idem, "English Medieval Village Community," 421-22.

72. Ault, "By-Laws of Gleaning," 212.

73. Hanawalt, "Peasant Women's Contribution," 12. 
exacted heavy fines on penny-a-day workers-reapers and binders, for example-who tried to supplement their incomes by gleaning. In 1319, for example, the homage of Great Horwood warned "that no one among them male or female be allowed to glean who can earn his food and a penny a day for his work. And also that no one of them shall accept any outsider to glean among them." ${ }^{74}$ Similarly, in 1395 the manorial court of Podington, Bedfordshire, ruled that "no one shall glean in autumn if there is anyone who wants to hire him at 1d. a day and food under the pain aforesaid."75 In 1309 Isabella Horn of Castle Acre, Norfolk, was fined for gleaning when she was fully capable of working as a reaper. ${ }^{76}$

In order to protect gleaning, village bylaws use the formulaic phrase quod nullus to set it in direct opposition with other harvest jobs. A bylaw from 1329, for example, stipulates "quod nullus extraneus admittatur ad gleniandum." Similarly, at Podington in 1395, bylaws decree "quod nullus asportat aliqua blada extra campos post tempus cariandi sub pena predicta" and "quod nullus coligat spicas in autumpno si aliquis se velit conducere cap' per diem j d. et mensam sub pena predicta." ${ }^{38}$ As Dyer has made clear, Langland was intimately familiar with manorial account-keeping and the rural landscape. And given Langland's concerns with wasteful consumption, bylaws may have had a certain appeal for the poet. Bylaws worked to ensure both efficiency and fairness, and, according to Ault, "the principle of procedure in harvest was haste without waste." 79 Although the pardon resonates with the exclusivity of village bylaws, it also moves beyond them to offer salvation to a wider circle of people. ${ }^{80}$ In a bylaw, no sower or reaper is permitted to glean. But for Langland, anyone who helps in the fall may glean come spring: "Whoso helpeth me to erie or sowen," he explains, "shal have leve, by Oure lord, to lese here in

74. Ault, Open-Field Farming, 89. Ault includes Latin transcriptions of 200 bylaws in his "Open-Field Husbandry."

75. Ault, Open-Field Farming, 112.

76. Ault, "Open-Field Husbandry," 58. Ault observes that "foremost among the offenders were women: they were able to reap but refused and gleaned" (48).

77. Bylaw from Newton Longville, Buckinghamshire: "Item that no outsider be given leave to glean." Ault, Open-Field Farming, 92. Latin transcription available in Ault, "Open-Field Husbandry," 60-61.

78. Bylaw from Podington, Bedfordshire: "And that no one shall transport any grain outside the fields after the time of carting under the pain aforesaid. And that no one shall glean in autumn if there is anyone who wants to hire him at 1d. a day and food under the pain aforesaid." Ault, Open-Field Farming, 112. Latin transcription available in Ault, "Open-Field Husbandry," 70.

79. Ault, Open-Field Farming, 27. On the related issue of theft prevention, see ibid., 36-38.

80. Dyer, "Piers Plowman and Plowmen," 156. 
hervest." ${ }^{\prime 1}$ The list of potential springtime gleaners is further expanded at the beginning of passus 7, when Truth dictates that anyone who does anything to help Piers will have access to the pardon: "Alle that holpen hym to erye, to sette or to sowe, / Or any maner mestier that myghte Piers availe- / Pardon with Piers the Plowman Truthe hath ygraunted." ${ }^{2}$ The verb lesen and its broad range of meanings perhaps serve to reinforce the pardon's role as a kind of spiritual labor contract; to lesen is to glean, but it can also mean to absolve, or to absolve oneself. ${ }^{83}$ In casting the Christian community as gleaners, Langland emphasizes the important link between penance and future salvation. Those who help on the half-acre can profit spiritually-they can share in the gleaning, or, as Langland puts it in passus 7 , in the pardon-by freeing themselves from sin. Much more than permission to collect the stubble left behind by reapers and binders, "to lese here in harvest" means both to live a penitential lifestyle and to enjoy the salvific rewards that such a lifestyle yields.

\section{Sewing the Half-Acre}

In claiming that those who help to "erie or sowen" can benefit from the harvest, Piers extends these rewards to a wider range of women. Manorial account rolls regularly record payments to women and mixed-gendered groups, and the employment of women as reapers is even taken for granted in late medieval books of estate management. ${ }^{84}$ This would seem to be confirmed in the

81. Langland, Piers Plowman, 6.65-66. For Dyer, "Piers Plowman's encounter with the wasters and beggars implies that a deep gulf had opened between the more substantial peasants and the cottagers and laborers." In restricting gleaning to those who help to plow and sow, "Piers seeks to force the able-bodied laborers to work and makes gleaning conditional on the acceptance of employment at other times of the year." "Piers Plowman and Plowmen," 168.

82. Langland, Piers Plowman, 7.5-7, emphasis mine.

83. MED, "lesen," v.1, from the OE lesan: “(a) to gather (ears of grain, clusters of grapes left by the reapers or pickers); glean." But compare with $M E D$, "lesan," v.5, from the OE lēsan: "(a) Of God, Christ: to redeem (man, the soul, etc.); from, (out) of, deliver (man, etc.) from (hell, the Devil, sin or its consequences, etc.); (b) refl. to free oneself (from suffering in hell), be absolved (of $\sin$ ); (c) to absolve (sb.) of sin, grant absolution." Although the two definitions I have highlighted here-to glean, to be absolved-descend etymologically from two different verbs, I would like to suggest that Langland may be yoking the two together in the service of presenting the pardon as a spiritualized labor contract.

84. On the subject of reaping and binding, the author of the anonymous late medieval Husbandry writes, "you should engage the reapers as a team, that is to say five men or five women, whichever you wish." Walter of Henley and Other Treatises of Estate Management, 445; see also the entry on Walter of Henley in Keiser, Manual of the Writings, 3689, 3902. On women's labor in rural settings more generally, see Goldberg, Women, Work, and Lifecycle, 137-49; Hanawalt, "Peasant Women's Contribution." The employment of women at harvesttime - and, in particular, the issue of pay equity—has been a subject of debate. Most recently, 
Luttrell Psalter, where women join men in the task of reaping. ${ }^{85}$ Whether or not this image represents an accurate picture of harvest practices, however, the inclusion of female labor in the Luttrell Psalter establishes women as part of the spiritual enterprise of the Luttrell household. In Piers Plowman, Langland's strategy is somewhat different. Instead of employing women reapers or gleaners-two tasks often ascribed to women-Langland makes a pun on the verb "sowen" and stretches agricultural metaphor to its fullest capacity in order to put women to work as seamstresses on the half-acre.

Langland lays the groundwork for the inclusion of women on the half-acre as early as passus 5, when a plowman named Piers comes on the scene to help navigate the way to St. Truth. He explains that he has long worked for Truth, as both a field laborer and as a clothworker: "'Peter!' quod a Plowman, and putte forth his heved,"

I knowe hym as kyndely as clerc doth hise bokes.

Conscience and Kynde Wit kenned [conveyed] me to his place

And diden me suren hym sikerly [assure him truly] to serven hym for evere,

Bothe to sowe and to sette the while I swynke myghte.

I have ben his folwere al this fourty wynter-

Bothe ysowen his seed and suwed [tended] hise beestes,

Withinne and withouten waited his profit.

I dyke [ditch] and I delve [dig], I do that he hoteth [orders].

Som tyme I sowe and som tyme I thresshe,

In taillours craft, in tynkeris craft, what Truthe kan devyse,

I weve and I wynde and do what Truthe hoteth. ${ }^{86}$

The first half of the passage emphasizes Piers's agricultural work-sowing is mentioned three times, along with digging, threshing, and caring for animals. But he also works as a weaver and tailor. Agricultural labor and clothworking, two disparate fields of labor, are yoked together under the umbrella term of

Bardsley has suggested that the comparatively high wages reported for women who worked as part of mixed-gendered groups are misleading: "Women's waged work," Bardsley asserts, "was consistently paid at about the same rate as that of the 'second-rate' workforce-boys, old men, and disabled men." "Women's Work Reconsidered," 22-23.

85. For Penn, this image serves as the primary visual source for women reaping. "Female Wage-Earners," 13. Roberts discusses the difference between sickle-reaping, which was often done by women, and scythe-mowing, which was done exclusively by men, in "Sickles and Scythes," 16-17. The reaping image from the Luttrell Psalter is unique in fourteenth-century English illuminated manuscripts, but see the late twelfth-century German example, particularly notable for the high-status clothing of the female reapers, in Sibylle Harksen, Women in the Middle Ages, plate 33.

86. Langland, Piers Plowman, 5.537-48. 
"what Truthe hoteth," what truth calls for. Sometimes he sows and threshes, and sometimes he winds yarn and weaves. Both types of labor are "devyse[d]" by Truth, and, in the closing lines of the passage, which gesture toward the Parable of the Vineyard, both are figured as forms of spiritualized vineyard labor. "I serve hym to paye," Piers claims, "I have myn hire of hym"-I have my pay of him- "wel and outherwhiles moore." The invocation of Matthew's parable recalls the Northern Homily Cycle, in which vineyard labor or "wirk" represents the spiritual operation of "Haly Kirk." ${ }^{88}$ Indeed, the half-acre community will comprise those who sew as well as those who sow.

At the start of passus 6, an unnamed "lady in a scleyre [veil]" asks what the women should do while they wait for the half-acre to be plowed and sown. "This were a long lettyng [delay]," she grumbles, "What sholde we wommen werche the while?" ${ }^{89}$ Her question draws attention to a glaring limitation of the pardon: if plowing constitutes the pilgrimage, then how are women to be saved? And, more particularly, how are women of different classes to be saved? The woman's "scleyre" is a status indicator-she is not a woman who reaps or gleans to help her family get by. ${ }^{90}$ Instead of giving her an agricultural task, Piers expands the parameters of sowing with a pun and puts the veiled lady to work with a needle and thread. The women will sew, and in ways that befit their varied status. "Somme shul sowe the sak," he says, "for shedyng of the whete,"

And ye lovely ladies with youre longe fyngres,

That ye have silk and sandel to sowe whan tyme is

Chesibles [chausubles] for chapeleyns chirches to honoure.

Wyves and widewes, wolle [wool] and flex spynneth:

Maketh cloth, I counseille yow, and kenneth so youre doughtres.

The nedy and the naked, nymeth [take] hede how thei liggeth,

And casteth [make] hem clothes, for so comaundeth Truthe. ${ }^{91}$

Langland forms a social hierarchy in which each woman has an appropriate job to perform on the half-acre, whether working with coarse cloth or fine silk. The first task, "sow[ing] the sak," aligns the women's work with that of the men: making sacks for wheat storage is an essential agricultural task, especially during harvest. In the process of stretching the agricultural meta-

\footnotetext{
87. Ibid., 5.549-50.

88. Northern Homily Cycle, 85, 88 (lines 89-90, 225-26).

89. Langland, Piers Plowman, 6.7-8.

90. MED, "skleire," n. a: "a veil, headdress; also, a cloak or an overgarment."

91. Langland, Piers Plowman, 6.9-16.
} 
phor, however-that is, in shifting from sowing to sewing - clothworking also comes to represent church maintenance and Christian charity. The lady in the veil, for example, will make ecclesiastical garments.

In order to include women on the half-acre, Langland finds a model in the parish church and its teaching on Christian charity. Fourteenth-century laypeople were responsible for the upkeep of the nave as well as the provision of various church fittings, and much of this responsibility was shouldered by women, both as individuals and as members of single-sex guilds. ${ }^{92}$ Katherine French observes that "women's care of their parishes mirrored that of their own households," ${ }^{\prime 3}$ and evidence suggests that some of this work centered on the production, mending, laundering, and tailoring of textiles used in the parish. ${ }^{94}$ In passus 6 , the tasks are socially differentiated: unlike the peasant women who sew wheat sacks, women of means work with silk to produce sumptuous church vestments, and this in turn is contrasted with the wool and flax being sown by wives and widows. The end of the passage, with its imperative commands_-"maketh cloth," "kenneth so youre doghtres," and "casteth" clothing for the needy ${ }^{95}$-reads like a piece of conduct literature, its directives spiritually inflected. In making clothes for "the nedy and the naked," Langland's clothworking women fulfill one of the seven Corporal Works of Mercy. ${ }^{96}$ Their work also aligns them with the Virgin Mary, who is herself sometimes depicted as sewing or knitting in images of the Annunciation. ${ }^{97}$

92. French, Good Women of the Parish, 122-32.

93. Ibid., 18.

94. For further discussion of the relationship between female piety, housekeeping, and the parish, see ibid., 17-49, esp. 29-34.

95. The verb "casteth," which can also refer to taking off or removing clothing ( $M E D$, “casten," v., 15), has perplexed some of the poem's modern editors. Bennett, for example, while acknowledging that the act of clothing the poor was one of the Corporal Works of Mercy, suggests that "cast, when used of clothes, should imply 'remove." Langland, Piers Plowman, ed. Bennett, 198, n. 16. In the context of the clothworking passage, "casten" means to put on, make, or provide. $M E D$, “casten," v., 19, 25.

96. Clothing the naked was closely associated with women in the Middle Ages, partly due to the legend of Tabitha (or Dorcas), a seamstress resurrected by Peter (Acts 9:36-43). See Anderson's recent discussion of the passage in Charity, 170-73. The story was popularized in the late medieval Book of Vices and Virtues, in which clothing the naked is described as a branch of the tree of mercy. The author reminds readers that "bi suche a dede" - that is, by clothing the naked-"seynt Peter arered [raised] pe good womman pat hizt Dorcas, for sche cloped pe pore, as holy writ seip." Book of Vices and Virtues, 205 (lines 17-19). French has suggested that, in gesturing to the Corporal Works of Mercy and in "relat[ing] some of these divisions back to work for the parish," Langland draws upon "broader and more ingrained assumptions about men's and women's piety," including those expressed in parish wall paintings and stained glass. Good Women of the Parish, 197.

97. Biscoglio notes that, in a wide range of visual sources from England and the continent, the motif of spinning works to link women with domestic virtues such as obedience and 
Throughout the fourteenth century, agrarian metaphor was central to the construction of spiritual community in both art and literature because the communal nature of open-field farming lent itself to the collective work of worship and salvation. But agrarian metaphor had its limits: the malecentered work of the land was ultimately an awkward analogy for the parish, rich with opportunities for women's involvement. Piers's pardon borrows language from the manorial regulation of harvest, which allowed for women's work, if in a somewhat limited capacity. More than an agrarian contract, however, Piers's pardon ultimately constitutes a broader and more inclusive statement of Christian charity as it was taught in the late medieval parish. As Langland claims again and again, those who do their part for the community on the half-acre will be rewarded at Judgment. For women in particular, this imperative manifests in acts of clothworking that benefit both the church and the poor. In addition to the imagery of communal harvest that we have seen elsewhere in the poem, the clothworking passage at the beginning of passus 6 puts the pardon formula to work in a context that strongly evokes the parish: those who help others will be saved. The enterprise on the half-acre ideally comprises a spiritually active and charitably minded lay community that includes both men and women.

\section{Field and Parish: The Spiritual Community of the Half-Acre}

If the pardon reads like a village bylaw, this changes the way we think about Piers and the authoritative position he occupies on the half-acre. Grace famously designates Piers as Reeve in the scene of harvest and barn building at the poem's end:

For I make Piers the Plowman my procuratour [agent] and my reve, And registrer to receyve Redde quod debes [what is owed].

My prowor [purveyor] and my plowman Piers shal ben on erthe, And for to tilie [cultivate] truthe a teeme [team (of oxen)] shal he have. ${ }^{98}$

motherhood. In the special case of Mary, spinning evokes her privileged role as "intermediary between God and Man, binding the divine and human together." "'Unspun' Heroes," 171. Rutt includes several examples of "knitting madonnas" from fourteenth-century Italy in History of Hand Knitting, 44-50, figs. 42-45. For a recent discussion of this iconography and its origins, see Miles, "Virgin Mary's Book," 637-38.

98. Langland, Piers Plowman, 19.260-63. 
This proliferation of occupations—reeve, purveyor, registrar, plowman-calls attention to the complexity of manorial administration. ${ }^{99}$ Reeves alone had a staggering number of responsibilities ranging from the hiring and supervision of laborers to the marketing of grain and animals and the collection of rents. ${ }^{100}$ In passus 19, Piers will oversee the tilling of "truthe" with responsibilities that correspond to aspects of Christian theology and devotion: he will drive teams of oxen and horses representing Gospel writers and exegetes; he will sow the cardinal virtues; he will build a barn mortared with the blood of Christ, wattled with the pains of the passion, and roofed with holy writ; and, finally, he will harvest the lord's living sheaves, collect them in a cart called Christendom, and store them in a barn called Holy Church. But his administrative capacity is not unique to passus 19: Piers is consistently described in managerial terms throughout passus 6 as well. Once the plowing of the halfacre has begun, Piers stops his work to supervise everyone else:

At heigh prime Piers leet the plough stonde,

To oversen hem hymself; whoso best wroghte,

He sholde be hired therafter, whan hervest tyme come. ${ }^{101}$

When he notices their laziness, he angrily claims,

Ye ben wastours, I woot wel, and Truthe woot the sothe;

And I am his olde hyne [servant] and highte [bidden] hym to warne

Which thei were in this world his werkmen apeireth [(who) harm his

workmen]. ${ }^{102}$

As overseer and "hyne" or servant of Truth, Piers is responsible for keeping his laborers on task.

When their idleness continues, he asks for Hunger's managerial advice: "Now wolde I wite of thee, what were the beste, / And how I myghte amaistren [govern] hem and make hem to werche." ${ }^{103}$ How can I achieve mastery over my workers, he asks; how can I make them do their jobs? If the pardon reads like

99. On Piers's authoritative roles on the half-acre, see Dyer, "Piers Plowman and Plowmen," 163; Harwood, "Plot of Piers Plowman," 101; Cole, "Scribal Hermeneutics and the Genres of Social Organization," 192-95. See also Barney's recent discussion of the terms "procuratour," "reue," "registrer," and "prowour" in Penn Commentary, 146-48.

100. Dyer, Making a Living in the Middle Ages, 122.

101. Langland, Piers Plowman, 6.112-14.

102. Ibid., 6.130-32.

103. Ibid., 6.210-11. 
a bylaw, this perhaps casts Piers in the role of keeper of the harvest, one of the custodes autumpni or harvest keepers elected to enforce bylaws. ${ }^{104}$ Like reeves, these keepers were part of the peasant elite, and manorial records typically record their election alongside the bylaws they were appointed to enforce. During their yearlong tenure, custodes autumpni were responsible for identifying bylaw offenders and presenting them at the manorial court. ${ }^{105}$ Unlike reeves, however, who served the interests of the lord, harvest keepers protected the interests of villagers. ${ }^{106}$ Piers straddles both worlds. A reeve working for the lord in passus 19, he is, in passus 6 and 7, a kind of harvest keeper who reinforces the agricultural basis of spiritual community on the half-acre: those who help will receive pardon, and those who do not help will be called out by Piers and punished by God. Beyond carrying out the demands of the manorial lord, Piers keeps his laborers in line with God's expectations for the collective Christian laity.

Bylaws are customarily recorded as having been enacted by the common consent of the village community-by agreement of the communitatis (community), ${ }^{107}$ for example, or per assensum tocius homagii (by the assent of the whole homage).$^{108}$ Ault records a number of instances in which bylaws are administered by the consent or ordinance of "the neighbors." 109 But, as Dyer has warned, these formulaic preambles should not be taken at face value; the emphasis on concordant decision making at the local level presents us with an ideal village in which harvest regulations are arrived ananimously by a harmonious cross section of villagers. ${ }^{110}$ Indeed, a number of bylaws specify enactment not by all villagers but by all of the lord's tenants, both free and customary: "Omnis tenentes domini tam liberos." ${ }^{111}$ Positions of authority, Dyer reminds us, were occupied by the "self-sufficient" peasant elite. ${ }^{112}$ Villages were diverse and socially stratified; their inhabitants cooperated, but not without conflict or divisions of interest. But bylaws, by regulating harvest, rights of pasture, and encroachment, sought to preserve and

104. In describing Piers as an authoritative "over-seer" in passus 6, Langland also looks to urban models of labor management; as Cole has recently argued, the treatment of labor on the half-acre is "framed by the language of the guild over-seer." "Scribal Hermeneutics," 194.

105. Dyer, Making a Living in the Middle Ages, 43-46.

106. Dyer, "Power and Conflict," 28; Ault, “Open-Field Husbandry," 44.

107. Ibid., 67 (1373 bylaw from Wistow, Huntingdonshire).

108. Ibid., 68 (1385 bylaw from Great Horwood, Buckinghamshire).

109. Ault, "Village By-Laws by Common Consent," 381.

110. Dyer, "Power and Conflict," 29-30; idem, "Piers Plowman and Plowmen," 163.

111. Ault, "Open-Field Husbandry," 66 (1357 bylaw from Great Horwood, Buckinghamshire); Ault, Open-Field Farming, 102.

112. Dyer, "Power and Conflict," 31; Dyer, "Piers Plowman and Plowmen," 163. 
perpetuate a sense of local community and a tradition of neighborly behavior. The transgressors that bylaws sought to reprimand appear regularly in fourteenth-century handbooks for priests. In Robert Mannyng's Handlyng Synne, for example, "fals husbandes" feature in a section on the Seventh Commandment: encroachment during plowing, Mannyng warns, "ys bope pefte and robborye." ${ }^{113}$ In Piers Plowman, encroachment is one of the many sins of avarice that Hawkyn admits to having committed:

If I yede [went] to the plowgh, I pynched [encroached] so narwe

That a foot lond [foot of land] or a forow [furrow] fecchen I wolde

Of my nexte neghebore, nymen [take] of his erthe;

And if I rope [reaped], overreche, or yaf hem reed that ropen [advised those who reaped]

To seise to me with hir sikel that I ne sew [sowed] nevere. ${ }^{114}$

Not only does Hawkyn greedily plow into his next-door neighbor's land, he filches his neighbor's sheaves, stealing grain he did not sow himself. In regulating the harvest, village bylaws seek to curtail the unneighborly behavior of encroachers and sheaf-stealers, such as Langland's figure of Hawkyn and Mannyng's "fals husbandes." And on Piers's half-acre, only those who help will receive pardon: filchers need not apply.

In stamping out the selfish encroachers chastised in penitential handbooks, village bylaws promote the kind of honest, collective toil rewarded on the half-acre. They also promote the charitable behavior associated with good neighbors and fellow parishioners. Evidence suggests that village bylaws took advantage of the connection between the agrarian community and the spiritual enterprise of the parish; as Ault has observed, beginning in the late fourteenth century, the proceeds from fines for bylaw infractions were, on many manors, shared with the church. ${ }^{115}$ This was increasingly the case in the fifteenth century, when churches all over England were investing in ambitious construction and decoration campaigns. ${ }^{116}$ Field and parish are coterminous: the preservation of the harvest community through the punishment of bylaw violators helps support the parish and its fabric. The bylaws' formulaic enshrinement of an idealized community where harmonious consent prevails resembles the medieval parish, which similarly imagined itself as a unified community, one that worked together to achieve salvation. The charitable

\footnotetext{
113. Mannyng, Handlyng Synne, ed. Sullens, lines 2445-49.

114. Langland, Piers Plowman, 13.371-75.

115. Ault, "Manor Court and Parish," 53-67.

116. Ibid., 62 .
} 
ideal was, in fact, a structural component of the Mass. Being in a state of charity with one's fellow parishioners was, in addition to being cleanly confessed, a prerequisite for receiving communion and participating in the corporate celebration of Christ's body. The "events" of the Mass, ${ }^{117}$ as Bossy has argued, emphasize social reconciliation within the congregation, beginning with the Pater Noster, which emphasizes mutual forgiveness, and ending with the kiss of peace and the priest's invocation of a charitable bond among members of the congregation. ${ }^{118}$ Those who lived charitably and received communion could count on being saved alongside their neighbors at the Last Judgment. Salvation theology and the charitable ideal are powerfully combined with spiritualized agricultural labor in the portrait of the plowman in the General Prologue to the Canterbury Tales. A walking paraphrase of the golden rule that Christians love both God and neighbor, Chaucer's Plowman is a "trewe swinker" who lives "in pees and parfit charitee," and who loves God "with al his hoole herte" and "his neighebore right as himselve." only behind the plow but also in his everyday dealings with others: "trewe swink" on the field and "parfit charitee" toward his even-Cristen.

In quoting from the Athanasian Creed and in evoking the separation not only of the saved from the damned at the Last Judgment but also the charitable from the uncharitable at communion, the pardon ultimately makes an appeal to parish ideology. Indeed, the half-acre and its workers, who share in the labor in order to share in the harvest, resemble a kind of parish in which communal spiritual labor among neighbors and even-Cristen leads to collective salvation. I say a kind of parish because it is, after all, a congregation of Piers's own assembling. Although rooted in parochial teachings and practices, the half-acre cohort has nevertheless been disconnected from the material parish. This disconnection is perhaps at its most acute in Piers's allegorical map to Truth which, as I argued in chapter 3, not only detaches lifelong spiritual pursuits from the material parish but also transforms them from actions into external places. If the half-acre episode trades the parish nave for the muddy field, however, Langland works to reunite the two at the poem's end by making a parish of a barn. In this bold reimagining of the familiar preacherplowman metaphor, Piers assumes the role of reeve and oversees the harvesting of bundles of parishioners, whom he piles into a cart and stores in a barn

117. Bossy, "Mass as a Social Institution," 29-61. See also Thiery's discussion of charity in relation to the liturgy of church dedication in Polluting the Sacred, 41-45.

118. "Habete vinculum pacis et caritatis ut apti sitis sacrosanctis mysteriis Dei", from the York Use, printed as an appendix to Lay Folks Mass Book, 114 (line 1).

119. Chaucer, Canterbury Tales, fragment 1, lines 532-35; Matt. 22:37-39. 
called "Unite" or "Holy Chirche on Englissh." 120 This barn-cum-parish is mortared by Christ's "baptisme and blood," wattled with the pains of his passion, and roofed with Holy Writ. ${ }^{121}$ The "cart highte Cristendom," piled high with Piers's sheaves, is driven to the barn with penitential horsepower from Contrition and Confession. ${ }^{122}$ In passus 19 , Piers is part of a spiritual enterprise in which agricultural work - not just plowing, sowing, and harvesting but barn building, too-represents the many labors of the church and its people, from the pastoral care provided by priests to the active penance of parishioners. To work the land in passus 19 is to build the church, populate it with parishioners, and perform sacraments within it. The salvific harvest collectively sown and reaped in passus 7 is, in passus 19, carted to and stored in a wooden barn made of sacramental and scriptural materials. Although the Barn of Unity has often been compared to an ecclesiastical tithe barn, its timber frame suggests a much more modest type of structure made of goods that could be gathered locally. ${ }^{123}$ The distinction is an important one, given the local nature and composition of the parish. The Barn of Unity and the Cart of Christendom are ultimately made of the stuff of lay devotion, the sacramental and liturgical labors of the local parish and its people.

120. Langland, Piers Plowman, 19.331.

121. Ibid., 19.326.

122. Ibid., 19.333.

123. Niall Brady, "Gothic Barn of England," 100-104; Hill, Manor, the Plowman, and the Shepherd 61-66. On the local materials used in the construction of nonecclesiastical barns see Harvey, History of Farm Buildings in England and Wales, 28-31. Barney suggests an allusion to the friars and their adoption of "a deliberate architecture of humility"; see his survey of scholarship on this topic in Penn Commentary, 155-56. 


\section{5}

\section{Reading the Prick of Conscience in the Parish}

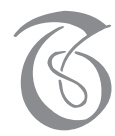

he well-known Prick of Conscience Window (c. 1410-20, fig. 6) ${ }^{1}$ chronicles the fifteen signs of the end of the world, a motif that would have been familiar to its late medieval audience. Beginning at bottom left and moving from left to right and from bottom to top, the window depicts a sequence of strange and terrifying events: the seas rise, retreat, and are restored; fish roar and waters burn; bloody dewdrops spring from trees; buildings collapse and stones strike one another; the earth quakes and is flattened; men emerge from caves, unable to speak; the bones of the dead rise; stars fall from the sky; all remaining people die; and, finally, the earth burns. The list of catastrophic events was synthesized from a variety of biblical and apocryphal sources by early theologians Peter Damian and Peter Comestor, whose Latin accounts formed the basis for the version found in the Golden Legend, where it came to be associated with Advent, the Last Judgment, and the second coming of Christ. ${ }^{2}$ The fifteen signs appear

1. Gee, "Painted Glass of All Saints' Church," 158; Pevsner and Neave, Yorkshire, 158.

2. For a detailed discussion of the motif and its origins, see especially Heist, Fifteen Signs Before Doomsday, 23-32, 109. 




Figure 6. The Prick of Conscience Window (c. 1410-20). All Saints, North Street, York, nIII. Photograph (C) Gordon Plumb. 
in poetry, drama, and sermons $s^{3}$ and in a variety of illuminated manuscripts, including the Holkham Bible. ${ }^{4}$ But the motif is much less common in other visual media, and the Prick of Conscience Window is a rare appearance of the motif in an English parish church..$^{5}$ The window's apocalyptic narrative closely follows the account that appears in the fifth book of the Prick of Conscience, a long, seven-part poem that examines the wretchedness of this life and the pains of the next, all in an attempt to help readers reform themselves and achieve salvation. ${ }^{6}$ Written in northern England between 1325 and $1350,{ }^{7}$ the Prick of Conscience survives in more copies than any other Middle English poem and was, by all accounts, extremely popular. Indeed, the window famously pairs each of the fifteen signs with a truncated Middle English quotation from the poem. ${ }^{8}$ It was commissioned by the local Hesyl family ${ }^{9}$ for

3. The fifteen signs appear in the Prick of Conscience, lines 4758-815; and Cursor Mundi, lines 22457-710. Bengt Lindstrom discusses descriptions of the fifteen signs (one in Middle English prose and the other in Latin verse with an English paraphrase) appearing in two manuscripts of Dives and Pauper. "Two Descriptions of the Signs," 307-11. Fowler lists the appearances of the motif in biblical, Latin, and Middle English literature in "Fifteen Last Days," 323-37. On drama, see Davidson, "Signs of Doomsday," 235-45. Treatments of the fifteen signs are found in a number of Middle English sermon collections including Mirk's Festial, 5 (lines 49-79); and the Northern Homily Cycle, 31-32 (lines 107-46). The earliest manuscript of the Northern Homily Cycle (Edinburgh, MS Royal College of Physicians) also includes a description of the fifteen signs in Latin, along with a note that the Latin verses are to be omitted when the sermon is delivered before a lay audience. Northern Homily Cycle, 31-32 (lines 147-180a). On the fifteen signs and homiletic tradition, see O'Mara, "Doomsday in Middle English," 282-84; idem, "Last Judgment in Medieval English," 29-31.

4. Gee surveys the appearance of the fifteen signs in illuminated manuscripts in an appendix to "Painted Glass of All Saints' Church," 199-202. For a discussion of the fifteen signs in the Holkham Bible, the Prick of Conscience Window, and English alabasters, see Gayk, "Present of Future Things." I thank Professor Gayk for sharing this forthcoming article with me.

5. As Powell notes, "It is the only stained glass window on the subject of the fifteen signs of doom extant, or known ever to have been extant, in England." "Text and Image," 294.

6. In the poem, stars fall on day 12 and bones rise on day 13; these events are reversed in the window, where bones rise on day 12, and stars fall on day 13. In an appendix to her article, Powell offers a useful comparison of the extant inscriptions with both a 1670 transcription of the window and Morris's 1863 edition of the poem. "Text and Image," 310-16.

7. For a discussion of the poem's dating, see Prick of Conscience, xxxv-xxxvi.

8. Edwards, "Middle English Inscriptional Verse Texts," 32; Richard Marks, "Picturing Word and Text," $180-83$.

9. No complete transcription of the Prick of Conscience Window's inscription survives; it was already "broken" in 1659 when Matthew Hutton saw it. But both he and later visitor Henry Johnston, who sketched the window in 1670, were able to make out the names of Abel Hesyl and his wife Agnes, as well as their daughter Cecily and her husband, Roger Henryson de Ulleskelf: "Rogeri Henrison et Cecilie uxoris ejus. Abel Hesyl et Agnete [words missing] et omni fidelium defunct." Roger Henryson married Cecily Hesyl, daughter of Abel Hesyl, who served as chamberlain of York from 1329-30 and bailiff from 1336-37. Cecily's brother Thomas Hesyl, a local merchant, married the daughter of a goldsmith. See Powell, "Text and Image," 
the north aisle of the York parish church of All Saints, North Street, between 1410 and 1420, at the height of what Michael Sargent calls the poem's "point of "market saturation.'" ${ }^{\prime \prime}$ In fact, by the time it appeared, the residents of York had already been leaving copies of the poem to friends and family members for several decades. ${ }^{11}$ I want to suggest that, in glazing this window, the Hesyls effectively bequeathed the poem-or, rather, a portion of it-to their parish church.

Making such an argument requires moving beyond the conventional observation that the window cites and illustrates the poem's treatment of the fifteen signs of the end of the world. Unfortunately, the window's engagement with the poem has received very little attention. ${ }^{12}$ This is perhaps unsurprising, given the general dearth of scholarship on the Prick of Conscience itself. ${ }^{13}$ Although the poem is in many ways oriented toward individual salvation, it continually engages the importance of communal worship, making repeated reference to the Mass and even imagining the occupants of heaven as an idealized liturgical community. The window takes up this theme, translating it into the local context of York and, more particularly, the parish of All Saints, North Street. The central panels draw special attention to the local impact of apocalypse, imagining how the end might look and feel and modeling appropriate modes of response for the window's viewers. These include shock and

298, n. 40. For a discussion of the window's transcription and a genealogy of the Hesyl family, see Gee, "Painted Glass of All Saints' Church," 161-62, 192-93, 198.

10. Sargent, "What Do the Numbers Mean?" 219. Hughes, writing about penance and pastoral care in late medieval York, claims that the poem "rapidly circulated throughout the diocese [...] in the second half of the fourteenth century. "Administration of Confession," 95.

11. For further discussion of Yorkshire bequests, see ibid., 107-9. Allen makes reference to several local testators (Thomas Roos of Ingmanthorpe left a copy to William de Helagh in 1399, and the third Lord Scrope of Masham left one to his sister in 1415) in Writings Ascribed to Richard Rolle, 384. On northern book ownership more generally, see Friedman, Northern English Books, 1-30; Goldberg, "Lay Book Ownership," 181-89. In treating the relationship between the Prick of Conscience and the parish of All Saints, North Street, scholars often cite the will of York chaplain William Revetour, who left his copy of the poem to Alice Bolton, daughter of a prominent All Saints parishioner named Nicholas Blackburn. For a transcription and translation of Revetour's will, see Johnston, "William Revetour," 158-71. But the document appears in 1446, more than twenty-five years after the window was glazed. As Powell has recently warned, we should not overemphasize the link between will, parish, and poem. "At the most," she writes, "it suggests that the right sort of people knew the text at roughly the right sort of time." "Text and Image," 299.

12. An important exception is Powell's close analysis of the window, particularly her discussion of its inscriptions in relation to seventeenth-century antiquarian records and the window's 1861 restoration by Knowles. Ibid., 310-16.

13. In recent years, the poem has begun to garner more attention from literary scholars. See especially Chickering, "Rhetorical Stimulus," 191-230; and Fitzgibbons, "Enabled and Disabled 'Myndes,"' 72-94. 
horror, of course, but in the panels along the window's bottom row, a group of nine kneeling figures also encourage viewers to channel their fear of the end into parochial worship in the present. Beyond offering a glimpse of the end of time, the Prick of Conscience Window issues a call to prayer and ultimately imagines the parish working together to achieve salvation.

\section{Figuring Community in the Prick of Conscience}

The Prick of Conscience aims to terrify. As the author repeatedly warns his readers, the purpose of his book is to stir up "drede", and he delivers on that promise by detailing at great length (over 9,600 lines) the wretchedness of this life and the pains of death, Purgatory, and hell. ${ }^{14}$ Even in the poem's seventh and final book, the poet explores the joys of heaven while drawing them into sharp contrast with the horrors of hell. ${ }^{15}$ If the book intends to terrify, however, it does so in the service of drawing readers from sin to salvation. Fear and dread, the poet explains, will put readers on the road to a "gude endyng." "Yf pai rede or here," he explains in the prologue, fear and dread will encourage them to "wirk gude werkes and fle foli." ${ }^{17}$ The book's frightening subject matter seeks to tenderize the conscience of the reader in such a way that he will reform himself in the here and now in order to enjoy salvation in the future..$^{18}$ Although the Prick-author aims to encourage his readers to "amende" their behavior, he offers little practical advice on moving from fright to actual change. ${ }^{19}$ The poem's lack of instruction on, for example, the tenets of the faith or strategies for avoiding sin, sets it apart from contemporary spiritual guides and, as Chickering argues, points to its different, more preparatory focus on the achievement of attrition, or "generalized awareness of one's own sinfulness." ${ }^{20}$ Instead of exploring remedies for sin, the poem "seems intended mainly to scare its audience." ${ }^{21}$

Even as he stirs up fear and dread, however, the Prick-author repeatedly gestures to the ideal of communal worship. When describing Purgatory in

14. "Pis buke es on Ynglese drawen [. . . for to stir pam til right drede." Prick of Conscience, lines $334,342$.

15. Chickering makes this observation in "Rhetorical Stimulus," 217.

16. Prick of Conscience, line 8 .

17. Ibid., lines 330, 335 .

18. "For if a man it rede and understandes wele, / And pe materes parin til hert wil take, / It may his conscience tendre make, / And til right way of rewel bring it bilyfe." Ibid., lines 9549-52.

19. Ibid., line 9555 .

20. Chickering, "Rhetorical Stimulus," 220.

21. Ibid., 193. 
book 4, for instance, he repeatedly emphasizes the crucial role that living "frendes" play in lessening the suffering of the dead, whether through prayer, the provision of alms, or the celebration of the Mass. Indeed, in illustrating the spiritual reciprocity that characterizes the relationship between the living and the dead, the Prick-author repeats the term "frende" nearly a dozen times in book $4 .{ }^{22}$ The dead can be helped "thurgh prestes hande" during the celebration of the Mass, as well as "thurgh prayer of his lyms [limbs], / Pat es, of gude men pat toward heven clyms [climbs]. ${ }^{23}$ The needy dead in Purgatory may "in pat nede," he continues,

Be boght fra payn thurgh almusdede;

Ande thurgh penance for pam here don,

pe dette of payn may be qwitte son.

Right als a man pat duelles in prison

Til he haf payed a certayn raunson,

May be delyverd and broght away

Thurgh a frende pat wille it for hym pay.

On pis wyse may pe saules pat wendes

Til purgatory, be helped thurgh frendes. ${ }^{24}$

Those in need may be bought from pain through alms and through penance done here on their behalf, their painful debt soon repaid. Just as a man imprisoned until he pays a ransom may be released and taken away by a friend who pays it on his behalf, in this same way may the souls in Purgatory be helped by friends.

Friends among the living can, through prayer and almsgiving, pay down the debt of their loved ones in Purgatory. The extent to which the dead rely on the help of the living in order to proceed along the path to salvation is reinforced in the rhyming of "wendes" and "frendes." The soul that "wendes" down to Purgatory can be brought back up, his downward spiral reversed, by the actions of vigilant "frendes" on earth. The living themselves also wend to heaven - those who pray for the dead are "gude men pat toward heven clyms," their actions in this life both anticipating and ensuring their own future reward among the saved. ${ }^{25}$ Ultimately, the dead in Purgatory and the living here on earth are conceived as parts of a unified whole: "Alle er als lymes of a

\footnotetext{
22. Prick of Conscience, lines 3091, 3225, 3567, 3621, 3623, 3624, 3626, 3718, 3796, 3888.

23. Ibid., lines 3598, 3600-601.

24. Ibid., lines 3614-23.

25. Ibid., line 3601 .
} 
body, / pat here er, and in purgatory." ${ }^{26}$ This body excludes the dead limbs that rot in hell-these must be "cutted" or "hewed." 27

Excerpts from book 4 of the Prick of Conscience appear in a fifteenthcentury Carthusian miscellany from northern England, where they are accompanied by an image that illustrates how the imperative to help one's dead "frendes" might be met within the parish. ${ }^{28}$ The excerpts make up part of a poem entitled "Of pe relefying of saules in purgatory." ${ }^{29}$ On the right-hand side of the page, a mechanical diagram consisting of a rope and a bucket links heaven, the church, and Purgatory (fig. 7). The bucket is filled with souls, "drawn up oute of purgatory by prayer and almos dede," an accompanying caption explains. The bucket rises up to heaven, leaving behind a fiery pit full of people. At the top of the page, God and the saved are gathered inside an ornate stone structure that resembles the top of a well while also evoking the decorative carving of church windows and arches. On the left side of the diagram, almsgiving and the Mass provide counterweights for the heavy bucket as it approaches the open doors of the building above. This two-part approach provides a practical illustration of the Prick-author's suggestion that help can be provided "thurgh prestes hande" as well as "thurgh prayer of his lyms": in fact, the rope passes through the hands of both the priest and his charitably minded parishioners. ${ }^{30}$

In both the poem and the fifteenth-century bucket image, the living play a central role in shaping heaven through their prayer, their almsgiving, and their participation in the Mass. This purgatorial reciprocity prefigures the liturgical community that the Prick-author envisions in heaven. Having spent

26. Ibid., lines 3630-31.

27. "For als lymmes pat are dede er pai / Pat er hewed fra pe body oway. / And als nathyng may help kyndely / pe lymes pat er cutted fra pe body, / Right swa alle helpes pat men can telle, / Availles pam noght pat er in helle." Ibid., lines 3712-17.

28. See especially Brantley's recent study of the manuscript in Reading in the Wilderness, 147-52; Gray, "Spiritual Encyclopedia," 99-116; Matsuda, Death and Purgatory, 151-67. For a black and white facsimile of the manuscript, see Hogg, Illustrated Yorkshire Carthusian Religious Miscellany. See also Wormald, "Some Popular Miniatures," 279-85.

29. Matsuda includes a transcription of the entire poem in Death and Purgatory, 243-44; cf. Prick of Conscience, lines 3566-71, 3586-89. Hanna and Wood observe a "close translation" of Hugh Ripelin's Compendium Theologicae Veritatis (Compendium of the True Theology, c. 1268) in this particular section of the poem. Prick of Conscience, 315, n. 3576-611. The relationship between the Prick of Conscience and the lyric found in the Carthusian miscellany has not been acknowledged by recent commentators. Lewis and McIntosh do not list this poem as one of the "extracts" contained in British Library, MS Additional 37049: see their Descriptive Guide to the Manuscripts, 155-56. Brantley describes the poem on f. $24 \mathrm{~V}$ as an "anonymous lyric." Reading in the Wilderness, 256.

30. Prick of Conscience, lines $3598,3600$. 




Figure 7. "Of pe relefyng of saules in purgatory." () The British Library Board, MS Additional 37049 (c. 1460-70), fol. 24v. 
much of the poem exposing readers to the wretchedness of life, death, and worlds beyond, he turns in book seven to the wonders of heaven. Unlike the "thraldom" or servitude of hell, ${ }^{31}$ heaven is a place of "fraunches," or franchise, a term that signals not only immunity or freedom but nobility, generosity, and, even more importantly for my purposes, membership or citizenship. ${ }^{32}$ Heaven is associated with a powerful sense of belonging. It feels like a family, the Prick-author explains, its residents like brothers and sisters. ${ }^{33}$ This sense of belonging is even more potently expressed in terms of musical concord. The Prick-author draws a sharp contrast, for example, between the sweet sound of heaven's "blisful company" 34 and the strife and debate of hell. ${ }^{35}$ The throats of the damned are filled with bitterness,$^{36}$ he explains, while the souls in heaven come together in "swete" speech and song. ${ }^{37}$ We might think here of the noisy cacophony of Dante's Inferno, which gives way to unison song in Purgatorio. In the Prick of Conscience, music similarly functions as what Stevens calls a "medium of spiritual experience"; it unifies the residents of heaven, bringing the saved together with angels, all singing with "ful delitabel voyces and clere," and all "lov[ing] God ay in pair sang." ${ }^{8}$

This heavenly chorus is also a kind of liturgical enterprise, constituted through the singing of the psalms. Quotations from the psalms appear throughout the Prick of Conscience, but in book 7, which focuses on the joys of heaven, the Prick-author uses them differently, attributing them to David but also putting them directly into the mouths of the saved. For instance, those in heaven are described as singing in thanksgiving for God's mercy, just as David does in Psalm 88:

31. Ibid., line 8002 .

32. Ibid., line 7992. Among its broad range of meanings in Middle English, fraunchise can refer to the rights and privileges of a city or town as well as to the body of people constituting that city or town. The state of being "of" or "in" the franchise refers to "having membership in the corporation" or "belonging to the corporation." $M E D$, "fraunchise."

33. "Pare sall ilk man als wele knaw other / Als a man here knawes hys syster or brother, / And wyt of what contre pai ware, / And wha pam gatt and wha pam bare." Prick of Conscience, lines 8274-77.

34. Ibid., line 9297.

35. "Pai salle ay stryfe and be at debate, / And ilkan other sal despice and hate. / Omang pam sal never be pees, / Bot hatreden and stryfe pat never sal cees." Ibid., lines 9422-25.

36. "Pair throtes sal ay be filled omang / Of alle thyng pat es bitter and strang." Ibid., lines 9426-27.

37. The music heard in heaven is associated with "delitabel voyces," "melody," "delytable noys," and "swet tones." Ibid., lines 9253-57.

38. Stevens, "Dante and Music," 5; Prick of Conscience, lines 9294-95. As Francesco Ciabbatoni reminds us, music becomes synonymous with the love of God in 1 Cor. 13:1-2 ("If I speak in the tongues of mortals and of angels, but do not have love, I am a noisy gong or a clanging cymbal"). "Dante's Organa," 17. 
Parfor pai sall luf him pe mare,

And pe mare him love and thank pare,

And als wele for other mens trispas

And other mens syn pat he heled has,

Als for pair awen pat pai wroght here.

Parfor says David on pis manere:

Misericordias Domini

in eternum cantabo.

He says: "I sall pe mercyes syng

Of our Loverd ay, withouten cesyng."

And swa sall all syng withouten ende,

pat tyll pe blys of heven sall wende. ${ }^{39}$

Therefore they shall love him the more, and the more love and thank him, both for forgiving other men of their trespasses and sins as well as forgiving themselves of their own. Therefore David says, in this manner, Misericordias Domini in eternum cantabo. He says, "I will sing the mercies of our Lord without ceasing." And so shall all those who go to heaven.

At first, the Prick-author uses the psalm quotation to substantiate his claim about the grateful feeling of those in heaven and to show the extent to which their experience compares with David's. But David's "manere" proves ultimately to be the same manner practiced among those in heaven: as David sang, so shall they all sing. But they do not just sing in the manner or style in which David sang - they sing the very same words. As the Prick-author shifts tenses, the biblical past comes into contact with the eternal time of the future, and the solo song of David becomes a collective endeavor. ${ }^{40}$ English translation adds yet another temporal dimension, making the song accessible to the present-tense reader. In moving from past to future to present, and in transitioning from solo voice to chorus, the Prick-author ultimately conceptualizes heaven in liturgical terms. He relishes the otherworldly and ineffable sound of heavenly music, which surpasses anything heard on earth, and all "with-

39. Prick of Conscience, lines 8344-55. "I will sing of your steadfast love, O Lord, forever." Ps. 88:2 (NRSV 89:1). See also lines 9304-11, where those in heaven follow David in singing Ps. 89:15.

40. For Kuczynski, the "speaking voice of the psalms is always both singular and plural, the utterance of an individual poetic voice and the sentiments of a community." Prophetic Song: The Psalms as Moral Discourse, xx. See also Zieman, who explains that "the Psalms, above all, were indicative of choral singing and the desire for univocality and community singing expressed." Singing the New Song, 42. 
outen any travayle" - that is, without instruments, hands, or mouths. ${ }^{41}$ And yet the song sung in heaven is also fundamentally mundane and recognizable because its words consist of the very same psalms that were sung in standard weekly rotation in the medieval church.

Even the poet's discussion of the end of the world in book 5 engages the ideal of spiritual community. He warns his readers to prepare themselves for an experience that will be "ful harde." ${ }^{2}$ "We shuld make us redy here," he warns, because the end might come at any time. ${ }^{43}$ From the rising of the seas to the fiery end of the earth, the Prick-author's chain of catastrophes centers on the destruction of the natural world, but it also witnesses a devastating societal breakdown. Amid the rubble, people will find themselves profoundly isolated from one another:

Pe ellevend day, men sal com out

Of caves and holes, and wend about

Als wode men, pat na witt can,

And nane sal spek til other pan. ${ }^{44}$

On the eleventh day, men will emerge from caves and holes and go about like crazy men who know no reason, and none will speak to the other.

Such a foreclosure of communication and social interaction is also a pervasive feature of hell, whose residents are compared to "wode men" who come together only in strife. ${ }^{45}$ As Fitzgibbons observes, the Prick-author repeatedly "compares the behavior of the damned to the actions of earthly mad people," a strategy designed to shock readers into a state of "uncomfortable mindfulness." ${ }^{46}$ If readers "embrace the fear and love of God to which their reason directs them," Fitzgibbons suggests, they will mitigate their own suffering at the end of time and avoid the isolation of hell. ${ }^{47}$ The kind of mindfulness that the Prick-author advocates is also deeply social: hell is, we remember, a place of discordant cacophony, and heaven a place of unison song. The social disruption of the end parallels and prefigures the experience of the damned,

\footnotetext{
41. Prick of Conscience, line 9263.

42. Ibid., line 3998.

43. Ibid., line 4008.

44. Ibid., lines 4798-801.

45. "Pai salle ilkane on other stare and gryn [snarl, gnash], / Als wode men dose here." Ibid.,

46. Fitzgibbons, "Enabled and Disabled 'Myndes," 91, 94.

47. Ibid., 94 .
} lines $7422-23$. 
but the Prick-author also makes it clear that the sequence of events ultimately constitutes a punitive measure against uncharitable behavior in the earthly present. "Byfor his last commyng," he explains, God will condemn the earth to destruction "agayn pe dasednes [lack] of charite." 48 The Prick-author uses fear to generate love, or caritas-love of God but also, as Matthew's golden rule prescribes, love of one's neighbor.

\section{The End Is Here and Now}

Scholars have long observed a close relationship between the treatment of the fifteen signs in the Prick of Conscience and the appearance of the motif in the Prick of Conscience Window. The window chronicles the end of the world in fifteen richly colored main panels, each neatly framed with an architectural canopy and each inscribed along the bottom with a two-line quotation from the poem. ${ }^{49}$ Despite this famous pairing of image and text, however, the window's broader engagement with the poem has received little attention, and many of its visual elements-its tracery lights, for example, which cap the window with traditional Last Judgment imagery, and the unidentified figures who kneel in prayer along its bottom row-have been largely ignored. In representing the fifteen signs, the Prick of Conscience Window not only illustrates an excerpt from the Prick of Conscience but also tailors it for a lay audience seeking instruction on how best to prepare for the end of time.

In a departure from typical representations of the fifteen signs, the Prick of Conscience Window emphasizes human observation, studding the window's main panels with human figures who model different forms of response to the signs..$^{50}$ Indeed, while a viewer might focus on any of the window's scenes of destruction, several panels offer a narrative that is more particularly focused on human fear and dread. The top center panel, for instance, features a domestic scene in which a small group of people, two of whom are confined to a bed, confront a skeletal figure of death..$^{51}$ Directly below this panel, we find another gathering of people emerging from caves. Across the middle row of

48. Prick of Conscience, lines 4903, 4906.

49. On aspects of glazier John Thornton's style, including his characteristic use of architectural canopies, see O'Connor, "Stained and Painted Glass," 365-67; Marks, Stained Glass in England, 51-53, 183.

50. As Gayk argues, the window "implies the need for an affective and repentant response to sight of the final days." "Present of Future Things."

51. Powell observes a discrepancy between the panel as it now appears (with two people in the bed) and the panel as it seems to have appeared in 1670 (with only one figure in the bed), when Johnston sketched it. "Text and Image" 304. 
the window, which covers days seven through nine, the robed prophet figures who occupy the architectural frames spring to life in their niches, gesturing with their hands to the nearby scenes of destruction as they look on in utter astonishment (fig. 8). These looks are echoed at eye level along the window's very bottom row, where nine kneeling laypeople react in wide-eyed horror to the drama unfurling above (fig. 9).

The window's representation of shocked people works in part to remind viewers that the end will come as a terrible surprise, a point foregrounded in the poem. When discussing doom in book 5 of the Prick of Conscience, for instance, the poet emphasizes its startling unpredictability. Paraphrasing the Gospel of Luke, he explains that the end of the world will happen suddenly and that the experience will rival the Flood and the destruction of Sodom. As it did during the days of Noah and Lot, apocalypse will take people by surprise as they go about the mundane business of daily life: eating and drinking, getting married, building houses, buying and selling things at market, planting crops. On the very day when Noah entered the ark, the Prick-author writes, "men ete and drank + war glade / And wedded wyfes and bridalles made." ${ }^{2}$ And when fire "rayned" down on Sodom, men "salde and boght / And planted, and bygged [built] and houses wroght." ${ }^{33}$ Not unlike the poem, the Prick of Conscience Window emphasizes the epic nature of the end-even the prophets are terrified. But the window pays even closer attention to the impact of the end of the world on the lives of everyday people.

Part of the window's strategy in conveying the horror of the end is to localize the catastrophe and imagine its effect on the city of York and the parish of All Saints, North Street. The window closely echoes the poem's description of falling buildings, towers, and castles on day seven, but its visual narrative offers a much more localized account of the destruction, setting day seven in a late medieval townscape that eerily evokes the city of York. To the right, a doorway with a portcullis recalls York's own impressive circuit of walls and gates. The center of the image is occupied by the ruins of a stone church, its toppled spire, now resting diagonally across a pile of rubble, perhaps evoking the spire of All Saints itself (fig. 8). ${ }^{54}$ The wasted cityscape envisioned in this panel invites viewers to imagine church and city tumbling down around them, an invitation reinforced by the astonished prophet figures who lean out of their architectural niches on the left- and right-hand sides of the panel and by the horrified laypeople along the bottom row.

52. Prick of Conscience, lines 4841-42.

53. Ibid., lines 4853, 4849-50.

54. The church's tower and spire, erected c. 1420, were probably either under construction or had been recently completed when the window was glazed. Tillot, "The Parish Churches," 369 . 


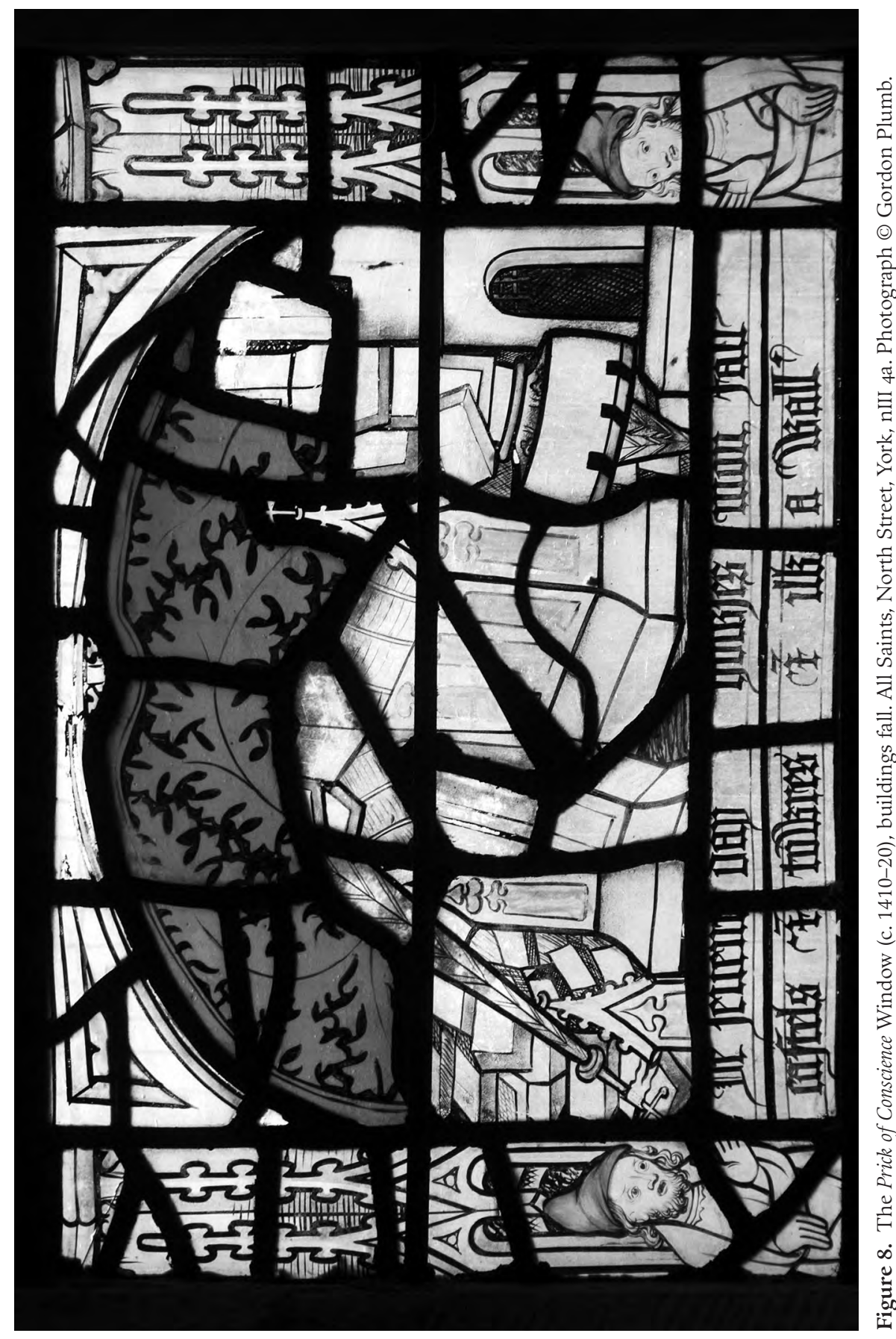




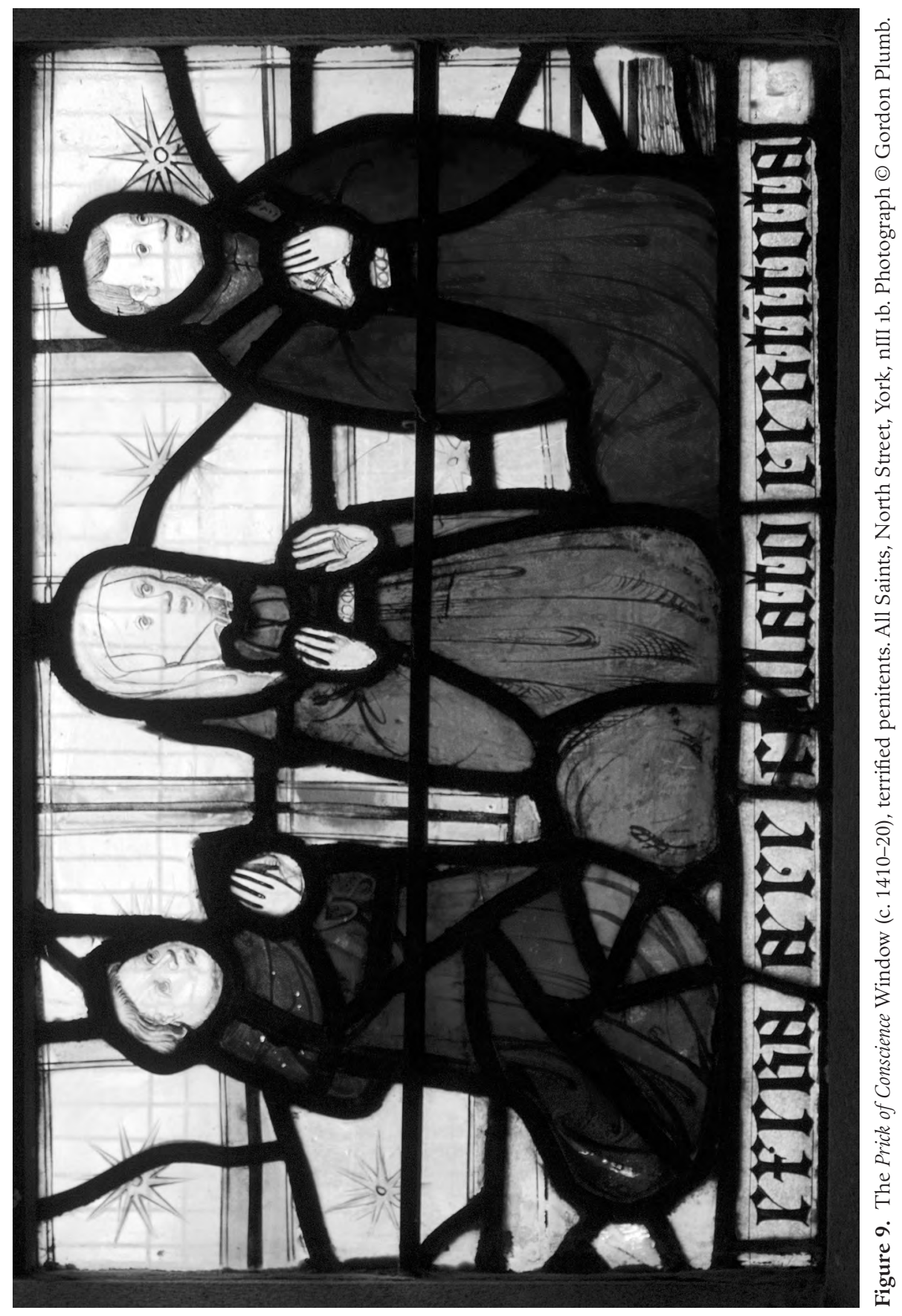




\section{Moving from Fear to Worship}

In addition to bringing doom closer to home and dramatizing its impact on both city and parish, the window also positions the fifteen signs in the broader context of the Last Judgment in order to encourage viewers to think about the spiritual implications of the end of time. Although the bedroom scene in the window's top central panel reminds viewers that the end will interrupt and even intrude upon everyday domestic life, this kind of deathbed scenario is not generally associated with apocalypse. In the Holkham Bible, for instance, the death of all remaining people is represented by a pile of limp bodies. ${ }^{55}$ The unusual addition of this image helps to link the narrative of the window's main panels with the Last Judgment scene appearing in the small tracery lights at its apex. As we know from Henry Johnston's 1670 transcription of the window, the top tracery light, now fragmented, once held an image of God the father. In the bottom right quatrefoil, still visible, brown devils push the souls of the damned down to hell, and at bottom left, a key-wielding St. Peter welcomes the saved at the gate of heaven. ${ }^{56}$ Such an iconographical program gives the domestic scene in the top row a key secondary function. Positioned beneath images of heaven and hell, the depiction of the death of all remaining people becomes a kind of deathbed ars moriendi scene. As the figure of death appears, holding a spear, two possible outcomes loom above the ailing couple. Will they be saved, or will they be consigned to hellmouth?

The nine figures depicted along the window's bottom row model the same wide-eyed response, but they also offer a practical guide for turning from fear to worship (fig. 9). Indeed, these panels seem to capture them in the very process of making this move: the kneeling figures have all turned to the east, but while some have already clasped their hands in prayer, others are just bringing their hands together in front of their bodies. The fact that they kneel-and that they kneel to the east, facing the high altar-signals their participation in the Mass. Kneeling was the central posture of the everyday Mass, a "liturgical commonplace," as Davlin puts it. ${ }^{57}$ The ceremony began with the laity on their knees for the opening prayer of confession and ended with the laity kneeling for the priest's final prayer of benediction. At other times of the year-Good Friday, for example-the posture was even more prominent..$^{88}$

55. Brown, Holkham Bible Picture Book, f. 41v. The scene juxtaposes the death of all remaining people with the dead rising from their tombs.

56. For a description of the tracery lights, including Johnston's 1670 account of the portions that are now lost, see Gee, "Painted Glass of All Saints' Church," 158.

57. Davlin, "Devotional Postures in Piers Plowman B," 163.

58. As observed by Weldon in his discussion of the liturgy of Holy Week. "Gesture of Perception," 63-64. 
Kneeling was also a posture that a congregation consciously assumed together. In the early fourteenth-century Lay Folks Mass Book, readers are instructed to kneel in tandem with their fellow parishioners at the beginning of the Confiteor, the prayer of confession at the start of the Mass: "Knelande on pi knese," the author writes, "als pou bisyde pe oper sese, / shryue pe pere of all pi synnes." ${ }^{29}$ This advice is part of the Mass Book's efforts to help nonLatinate readers negotiate the Latin Mass by offering useful tips on what to do and when. Kneeling is a central part of the experience, an outward expression of one's active involvement in the celebration of the Mass. If, as Veronica O'Mara has suggested, the very idea of doomsday could function as a "spur to good behaviour," in the Prick of Conscience Window, the fifteen signs issue a call to collective worship. ${ }^{60}$ The window's nine figures look ahead to the spiritual community of heaven while also modeling the ideal parish in the here and now. Throughout the Prick of Conscience, the poet repeatedly brings fear and dread into sharp contrast with, for example, purgatorial friendship and the liturgical harmony of heaven, presenting his readers with the ideal of collective worship even as he aims to instill terror. The poem's terrified readers should move from fear to love and, ultimately, salvation in heaven. In the Prick of Conscience Window, the nine kneeling figures offer a practical model for achieving this goal, their posture suggesting to viewers that the best way to avoid the horrifying outcomes that the window depicts might be to kneel before the high altar with the rest of the congregation. ${ }^{61}$ The fifteen signs inspire fear, but in the Prick of Conscience Window, they also become a tool of collective worship.

\section{The Prick of Conscience in the North Aisle}

Medieval laypeople were regularly confronted with the end of the world, typically in the form of a Last Judgment mural looming over the nave from the chancel arch. But in the parish of All Saints, North Street, the apocalypse makes a somewhat more unusual appearance in the north aisle. In bringing the Last Judgment and the end of the world down to eye level and linking

59. Lay Folks Mass Book, 6 (lines 53-55).

6o. O’Mara, "Doomsday in Middle English," 283. Burgess argues that the "arrangement of stimuli" in a Last Judgment painting "acted as a mainspring to prompt action, be they good works, almsdeeds, or service for others and in the interests of the parish." "Death and Commemoration in an English Parish," 47.

61. As Stevenson has recently observed, the kneeling donors, appearing at eye level, "inhabit the viewer's physical space, kneeling and praying alongside his or her body." Performance, Cognitive Theory, and Devotional Culture, 75. 
both with parochial worship, the Prick of Conscience Window works in tandem with other pastorally inclined windows in the north aisle, most notably the Corporal Works of Mercy Window (c. $1410-35,{ }^{62}$ fig. 10), which emphasizes mutual help and charity. The window was commissioned by one of York's leading citizens, the merchant and one-time mayor Nicholas Blackburn $\mathrm{Sr}^{63}$ It appeared at about the same time as the Prick of Conscience Window, and both are believed to have been produced by the workshop of Coventry glazier John Thornton. ${ }^{64}$ The Corporal Works of Mercy Window features Blackburn himself performing the acts of charity prescribed in the Gospel of Matthew; greeting the needy with baskets of food and armfuls of clothing, he welcomes strangers with a gesture of his hand in the window's upper right-hand panel and visits a prison and the home of a sick person in two of the middle-row panels. In making such a display of charitable provision, the window takes up a subject that was popular in other local media, particularly the York Corpus Christi plays. ${ }^{65}$ The Corporal Works of Mercy are central to the York Last Judgment, for example, in which the merciful treatment of the poor is presented as a hallmark of social unity. As Kate Crassons notes in her study of late medieval poverty, when the figure of God separates the saved from the damned, he chastises the latter for chasing away the poor, shutting them out at their doors and gates. ${ }^{66}$ "When I had mister of meat and drink," he announces, "ye catched me from your gate," and when he "wist never where for to rest," they "drove [him] from [their] door." ${ }^{67}$ The saved, by contrast, have upheld a social ideal "defined by consistent and concerned interaction between rich and poor," keeping their gates and doors open rather than closed. ${ }^{68}$ Blackburn, too,

62. Gee, "Painted Glass of All Saints' Church," 162.

63. Nicholas Blackburn Sr. was Lord Mayor from 1411-12, and his son and grandson followed suit in the 1420 s and 1430s. Gee, "Painted Glass of All Saints' Church," 197.

64. For a discussion of an inventory from 1409-10 that may link Thornton with All Saints, North Street, see Royal Commission on Historical Monuments, City of York, 3-4; Marks, Stained Glass in England, 181-82. Powell warns that the link "is perhaps not as strong as is usually suggested." "Text and Image," 297. In addition to his windows at All Saints, North Street (the Prick of Conscience, Corporal Works, and Nine Orders of Angels Windows), John Thornton was also responsible for a number of windows elsewhere in the city of York (including York Minster and the parishes of St. Denys, Walmgate, and St. Michael, Spurriergate) and the wider region. Marks, Stained Glass in England, 182-83. On Yorkshire Glass Painters more generally, see Pevsner and Neave, Yorkshire, 50-59.

65. Nicholas Blackburn enacts the six Corporal Works of Mercy outlined in Matt. 25:34-36; the seventh, burying the dead (described in Tob. 1:16-17), is not pictured in the window. For further discussion of the Corporal Works of Mercy, see chapter 3.

66. Crassons, Claims of Poverty, 253.

67. York Mystery Plays, 278 (lines 325-26, 337-38).

68. Crassons, Claims of Poverty, 254. For Boboc, the charity performed by the good souls is "a social solution meant to address (and arguably redress) the socio-economic gaps of the medieval city onstage." "Lay Performances of Work and Salvation," 261. 


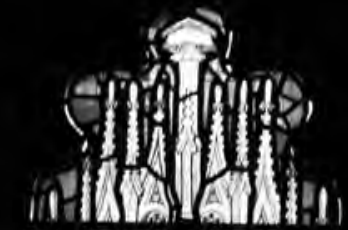

(i) iles

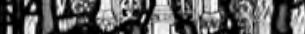

Ito :

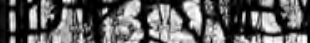

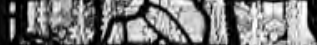

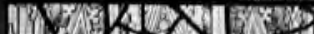

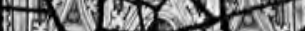

I

If $3 x$ ind

If

$102 \mathrm{~N}^{2}$

Maras

- Aration

-

निए

a $F$ on

$12.25)^{4}$

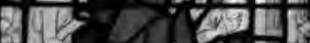

ANo $=5$

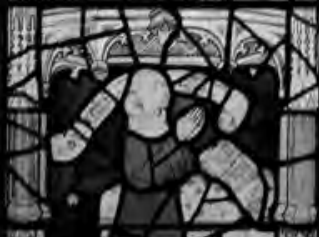

III



IA

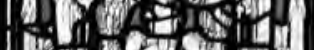
(14) 5 exp in


De

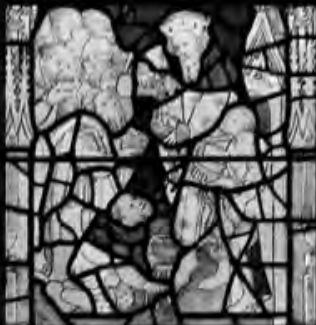

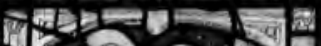
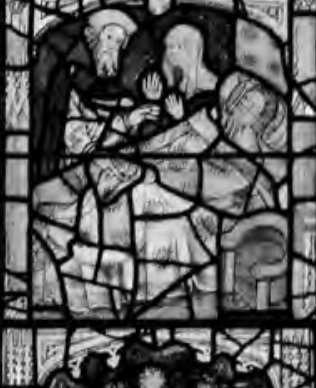

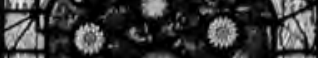



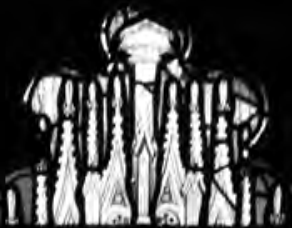
if Th= Perat 140.501 138 25 X्र 1) 201210 (6) at 60 Co

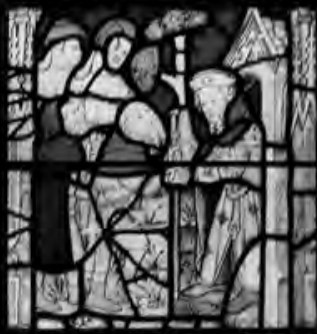
अंत्या


ing 201 - Min 1.1020 5. 6.2 C

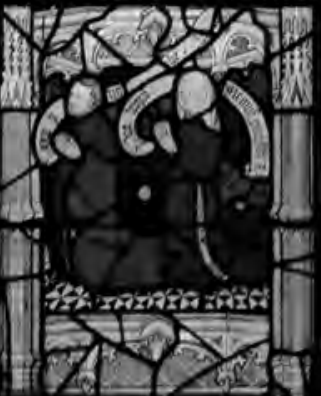

Figure 10. The Corporal Works of Mercy Window (c. 1410-35). All Saints, North Street, York, nIV. Photograph @ C Gordon Plumb. 
works to close the gap between himself and the less fortunate. Instead of barricading himself against the poor with walls and gates, he opens his door to strangers and makes the rounds among prisoners and the sick. ${ }^{69}$ The spiritual implications of his actions would have been familiar to the window's viewers. The Corporal Works of Mercy were regularly preached from the pulpit and were a popular subject in the art of the parish church. We might also think of the Prick-author's appeal to mutual help and friendship and, even more to the point, to his warning that God will punish humans at the end of time for their lack of charity. In treating subjects that were part of the standard repertoire of lay instruction and in encouraging viewers to engage with their fellow parishioners, whether liturgically or through an act of charity, both the Prick of Conscience Window and the Corporal Works of Mercy Window offer practical guides to a life worthy of salvation. And yet although the main panels of the Corporal Works of Mercy Window pay tribute to Blackburn's selfless charity, their altruistic message was tempered by two donor panels explicitly devoted to expressing his professional status. The panels disappeared at some point between 1730 and 1846, when the two-light window was moved to its current location, and its panels were reset across three main lights. ${ }^{70}$ In 1691 , however, when antiquarian James Torre viewed the window in its original location and layout, he recorded having seen "the figure of Nicholas Blackburn in one light and his achievement of arms in the other." ${ }^{\prime 1}$ Even as it celebrates the charity of a fellow parishioner whose benevolence knocks down barriers between rich and poor, the window ultimately reinforces the divide by reminding the viewer of Blackburn's prominence.

The family's wealth and piety are also on display in another north aisle window (fig. 11). ${ }^{72}$ Although it now occupies the east wall of the church, the Blackburn Window originally appeared alongside the Prick of Conscience Window, just one bay to the viewer's left. The window's central light features an image of St. Anne teaching the Virgin Mary how to read, and the reading motif appears again in the donor panels at bottom left and right, in which Margaret Blackburn and her daughter-in-law kneel alongside their husbands,

69. In her discussion of the "emergent capitalist environment" of late medieval York, King has suggested that the Corporal Works of Mercy Window offers "a model for how cash profit could be used, as opposed to fasting, praying, or fighting the infidel, to give the tradesman access to heaven." "York Plays, Urban Piety, and the Case of Nicholas Blackburn," 42, 43.

70. Gee discusses the movement and resetting of the window in "Painted Glass of All Saints' Church," 162. The window's current donor panels, featuring a couple at prayer and an image of local merchant Reginald Bawtre, do not belong to the window. Ibid., 164.

71. Ibid., 162, 194.

72. Gee suggests that the window "probably" dates to $1412-17$, but "possibly as late as c. 1435." Ibid., 153. 


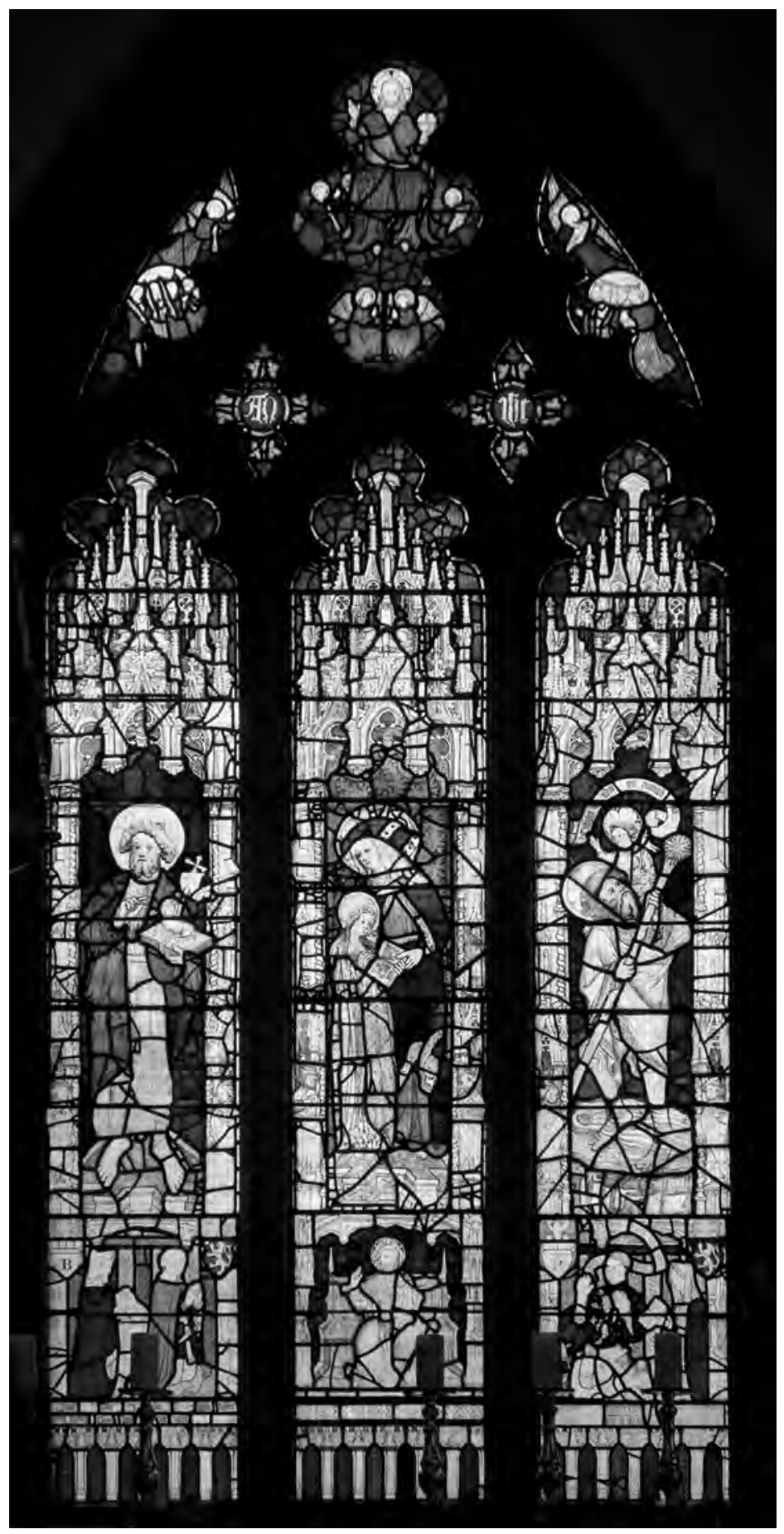

Figure 11. The Blackburn Window (c. 1412-35). All Saints, North Street, York, I. Photograph (c) Gordon Plumb. 
each woman holding a Latin-inscribed book in her hands. ${ }^{73}$ The window emphasizes both book ownership and devotional literacy, particularly among the female members of the Blackburn family. Like St. Anne, the window suggests, Blackburn wives own and avidly use personal Latin prayer books, and they teach their daughters how to read. It is likely that the well-known Bolton Hours were first commissioned by Margaret Blackburn for use with her young daughters, and the window itself seems to represent the Blackburn wives using this very sort of book. ${ }^{74}$ As others have pointed out, the text visible at bottom left-Domine labia mea aperies et os meum-is the opening phrase of the Office of the Virgin, a centerpiece of the medieval book of hours. ${ }^{75}$ The caption fits well with the window's Marian focus, of course, but it also reflects a broader concern with the promotion of bookish piety-the window pairs the opening lines of the Office of the Virgin with a sampling of other primer texts, including excerpts from the Penitential Psalms and the Office of the Dead. ${ }^{76}$ In addition to showcasing the Blackburns' spiritual interests and habits, the books figured in the window also work to express their wealth and status. The Blackburn shield of arms remains visible at bottom left and right, and the border once displayed the family's merchant's mark, held aloft by angels. ${ }^{77}$ In the bottom right-hand panel, Nicholas Blackburn Sr. sports armor and a pair of spurs in homage to his brief service as Admiral of the Fleet. ${ }^{78}$ The prestigious prayer books are yet another marker of the family's success.

73. Margaret kneels next to Nicholas Blackburn Sr.; her daughter-in-law (also named Margaret) kneels beside Nicholas Jr. On the window and its expression of female piety, see especially King, "Nicholas Blackburn," 46-47; Pederson, "Piety and Charity in the Painted Glass of Late Medieval York," 34-37. Zieman treats this image in her discussion of books of hours and "repertory-based" lay literacy, a "social practice, whereby texts were transmitted from page to person." Singing the New Song, 131. For Scase, images such as these are "exemplary representation[s] of learning" that offer "education in Marian worship." "St. Anne and the Education of the Virgin," 93. Clanchy also discusses the Blackburn Window in "Did Mothers Teach Their Children to Read?" $146-49$.

74. The book eventually came to be owned by Margaret's daughter Alice, after her marriage to John Bolton. See Cullum and Goldberg, "How Margaret Blackburn Taught her Daughters," 225; King, "Nicholas Blackburn," 47; Rees Jones and Riddy, "Bolton Hours of York," 220-24.

75. "O Lord, open my lips, and my mouth will declare your praise." Ps. 50:17 (NRSV 51:15). As Scase notes, this particular text is "wittily appropriate for someone learning to read aloud." "St. Anne and the Education of the Virgin," 93.

76. At bottom left, Margaret Blackburn reads from Ps. 6; one of the Seven Penitential Psalms, it was also used in the Office of the Dead. In the main center light, Mary and Anne read from Ps. 142, the seventh of the Seven Penitential Psalms. Gee, "Painted Glass of All Saints' Church," 155-56. On the liturgical contents of books of hours, see especially Wieck, Time Sanctified, 157-67.

77. As Gee notes, consulting Johnston's notes on the bottom left panel, "the shield now containing the B had a merchant's mark in it in 1670." "Painted Glass of All Saints' Church," 156.

78. He held the position from 1406-7. Kermode, Medieval Merchants, 51. 
The Blackburn Window and the Prick of Conscience Window appear in the fashionable north aisle, an area that became increasingly crowded with altars, grave slabs, and chantry chapels during the later medieval period. In fact, the location of the windows seems to have been dictated, at least in part, by the changing floorplan; their glazing coincided with the founding of William Vescy's chantry chapel, an addition that required the widening of the aisle. ${ }^{79}$ Surrounded by "parclose" wooden screens (solid or "blind" on the bottom but consisting of open tracery on top), ${ }^{80}$ chantry chapels offered a partial form of enclosure that allowed occupants "to be at once both seen and removed," as Graves puts it. ${ }^{81}$ The screens have long since been taken down, but Barnwell reminds us that the interior of the church would originally have been "fragmented into a series of semi-private spaces, the main public area being relatively constricted and probably feeling very closed-in on itself by the screens." ${ }^{\prime 2}$ Even as they crowded the aisle, however, parclose screens were designed to preserve sightlines in cramped quarters, and Barnwell suggests more optimistically that, at All Saints, North Street, "laymen standing in the nave could see into the chapels, with their colourful windows." ${ }^{83}$ And yet even if chantry screens did not obstruct the Prick of Conscience Window entirely, they certainly framed the view.

In the elite context of the north aisle, the Blackburns and Hesyls use visual imagery to cultivate very different relationships between themselves and the wider parish. Both windows position their patrons in relation to wider Christendom with formulaic inscriptions that commemorate not only the family but the faithful departed more generally. Pray for the souls of Mayor Nicholas Blackburn and his wife Margaret, one inscription reads, and for "omni fidelium defunctorum," all of the faithful departed. ${ }^{84}$ But reading practices, writ-

79. Barnwell, "Care of Souls," 71-73. York had more perpetual chantries "than any provincial town in fifteenth-century England." Dobson, "Citizens and Chantries," 314. On Yorkshire piety more generally, see Vale, "Piety, Charity and Literacy," 1-32.

80. Roffey, Medieval Chantry Chapel, 55.

81. Graves, Form and Fabric of Belief, 81. Duffy sees chantry chapels as part of the "complex space" of the parish, made up of a "constellation of groups, families and individuals." "Late Medieval Religion," 6o. Burgess has argued that the endowment of chantry chapels benefited the parish as a whole, enriching not only the founders' religious experience but that of their fellow parishioners as well. "Chantries in the Parish," 46-65.

82. Barnwell, "Care of Souls," 77. Woodcock notes that "the further east one travels [in the north aisle], the more restricted spaces become." "Social and Symbolic Space," 69. Duffy includes photographs of extant chapels with parclose screens in two recent publications. See "Late Medieval Religion," 61 (fig. 34); and Marking the Hours, 55 (fig. 41).

83. Barnwell, "Care of Souls," 77.

84. Roger Dodsworth transcribed the inscription in 1618: "Orate pro animabus Nicolai Blakeburn senioris quondam maior istius civitatis Ebor, et Margarete uxoris sue et omnium fide- 
ten texts, and parochial ritual are deployed to very different ends in the two windows. Books and reading function as markers of status and piety in the Blackburn Window. In the Prick of Conscience Window, however, vernacular reading issues a call to parochial worship and positions the Hesyls among their fellow parishioners, all kneeling together and working toward salvation. Although we might be tempted to conclude that the Latin books in the Blackburn Window evoke an explicitly private form of devotion, Eamon Duffy has argued that we ought to think of books of hours as promoting interiority rather than isolation. They did so, Duffy suggests, in a wide range of contexts that included both the privacy of home and the more public context of the parish nave. "Precisely because they were part of the liturgy," he reminds us, "the prayers of these books were not merely used privately" ${ }^{\prime 5}$ Beyond reflecting the domestic piety of the Blackburn women, then, the window points to their use of Latin primers as a means of enriching their worship at All Saints, North Street. It is important to note, however, that the window also depicts the family praying at an altar of its own - a stark contrast with the Prick of Conscience Window just one bay to the viewer's left, in which nine unidentified kneeling figures face the high altar at the end of the church. In the Blackburn Window, reading is, above all, a familial enterprise: women teach their daughters to read (perhaps even from primers that will be passed from one daughter to the next), and successive generations of husbands and wives kneel together in penitential prayer.

In the Prick of Conscience Window, reading becomes a parochial enterprise. We may never know for certain whether or not the nine kneeling figures along the window's bottom row represent members of the Hesyl family. In fact, the panels seem to de-emphasize the connection by eschewing the traditional iconography of patronage. There are no shields, for example, to signal the family's pedigree. ${ }^{86}$ Nor are there books or reading lecterns: the Hesyls have not depicted themselves as book owners. In fact, the uncertainty of their connection to the Prick of Conscience has frustrated generations of scholars. Regardless of whether or not the Hesyls actually owned a copy of the Prick of Conscience, I want to suggest that they shared the poem-an excerpt of it, to be more precise-with their parish when they glazed the Prick of Conscience Window. The window is itself a kind of monumental book, its pairing

lium defunctorum." Gee, "Painted Glass of All Saints' Church," 156. On the Hesyl family and the Prick of Conscience Window's inscription, see above, note 9.

85. Duffy, Marking the Hours, 53-64, at 60.

86. See especially Griffith, "Portrait of the Reader," 209-35; Marks, Stained Glass in England, 1-10. On donor portraits in manuscript illumination, see Morgan, "Patrons and Devotional Images," 93-121. 
of text and image reminiscent of the Holkham Bible, for example, in which vivid images of the fifteen signs are paired, four to a page, with vernacular captions. $^{87}$

One wonders, of course, whether or not the average layperson standing in the nave would have been able to read and properly identify the window's Middle English captions. In terms of its visual iconography, the Prick of Conscience Window is unique among English stained-glass windows. But its incorporation of vernacular verse is perhaps not all that unusual. As a number of scholars have recently suggested, vernacular inscriptions were quite common in the medieval parish church, appearing not only in the context of wall paintings but in tapestries, painted tables, and monuments of brass and stone. ${ }^{88}$ Madeleine Gray, for one, sees the addition of textual material as a strategy for lending authority and prestige to an image. ${ }^{89}$ Beyond enriching the image itself, however, textual material also enriched and expanded a viewer's experience of it, occasioning a wide range of interpretive possibilities in the process. For Edwards, verse inscriptions facilitate the "public display" of written material..$^{\circ}$ In doing so, they have the potential to substantially widen the ambit of a text by transforming the viewers of an image-both literate and nonliterate, lay and clerical-into a kind of textual community.

As we know from Brian Stock and others, medieval textuality stands at the busy intersection of individual, community, and social practice..$^{91}$ In glaz-

87. The images that appear in churches have often been seen as books for the illiterate layperson-libri laicorum, as Gregory the Great famously put it. Gayk observes that “Gregory's emphasis on the pedagogical import of the image became the standard defense of visual art in the West throughout the Middle Ages." Image, Text, and Religious Reform, 5. For a discussion of Gregory's treatment of word and image, see especially Nichols, "Books-for-Laymen," 458-59. Duggan offers a useful overview of post-Gregorian approaches to visual art throughout the late medieval period and beyond. "Was Art Really the 'Book of the Illiterate'?" 63-107.

88. On the wide range of parochial media in which inscriptional verse texts appear, see especially Marks, "Picturing Word and Text."

89. Textual captions often serve an identificatory function, but they also "add weight to [a wall painting's] message," Gray writes. "Text was," she adds, "one of many strategies to impress." "Images of Words", 17, 26.

90. Edwards, "Middle English Inscriptional Verse Texts," 42.

91. As Stock explains, "relationships between the individual and the family, the group, or the wider community are all influenced by the degree to which society acknowledges written principles of operation." Textual communities are "groups of people whose social activities are centered around texts, or more precisely, around a literate interpreter of them." Implications of Literacy, 88. For Briggs, textual community constitutes "a group of people, each of whose members identify with the others not according to family, status, or locale, or at least not principally, but according to a common viewpoint as defined by a body of written texts." "Literacy, Reading, and Writing," 405. See also Kelly and Thompson, who argue that books are "constitutive of a community's sense of itself." "Imagined Histories of the Book," 9. For a recent discussion of books as "associative objects" that produce and are themselves the products of "social interaction," see Coleman, Cruse, and Smith, Social Life of Illumination, 2. 
ing the Prick of Conscience Window, the Hesyls transformed their parish into a textual community by folding the Prick of Conscience into the ritual life of All Saints, North Street. Although we often think of the poem as offering instruction for the individual penitent, the window reframes its treatment of the fifteen signs as a spur to collective worship. The Prick of Conscience inspires fear and dread, we may recall, while also reminding readers of the importance of mutual help and the Mass and, ultimately, of the ideal spiritual community they are likely to enjoy in heaven if they amend their behavior in this life. The Hesyls' window takes up some of the poem's most central concerns by localizing the horror of the end and linking it with the urgency of the Last Judgment and, moreover, by encouraging viewers to move from fear to worship. By virtue of the window's location in the north aisle, this collective enterprise also includes the clergy. If Miriam Gill is right in speculating that priests gestured to north-aisle wall paintings during their sermons, they were perhaps just as likely to make use of north-aisle windows..$^{92}$ Gee has suggested that James Baguley, who served as vicar of All Saints, North Street, between 1413 and 1440, was "the prime mover of the whole scheme of glazing,"93 and it is possible that he himself had access to a copy of the poem. ${ }^{94}$ To what extent might the window reflect Baguley's own desire, with the support of the Hesyls, to help his parishioners learn from this extremely popular poem? Nicole Rice has suggested that the Prick of Conscience "offers a certain independent literary access to means of 'self-correction"” while also "locat[ing] the lay reader firmly within the penitential nexus, in need of assistance and frequent recourse to the clerical advisor." 95 Indeed, the Prick of Conscience Window endorses and facilitates such a relationship between the lay viewer in the nave and the priest in the pulpit. In the context of the church service and even, perhaps, in the context of Baguley's sermons, image and text become tools for collective salvation. The nine kneeling figures along its bottom row are a model of how the parish of All Saints, North Street, might go about preparing for the Last Judgment.

In excerpting and adapting the Prick of Conscience for a parochial audience, the window is nothing short of an "act of vernacular theology," to borrow Gillespie's phrase. ${ }^{96}$ And a versatile one, given its appearance on the heels of Arundel's Constitutions and the "draconian" antiheretical campaign that

92. Gill, "Preaching and Image", 175.

93. Gee, "Painted Glass of All Saints' Church," 190.

94. As Powell reminds us, the poem was probably being copied by northern priests "for their own teaching and preaching use." "Text and Image," 299.

95. Rice, Lay Piety and Religious Discipline, 14.

96. Gillespie, "Vernacular Theology," 419. 
many have seen as flipping the switch on vernacular theological writing. ${ }^{97}$ Whether or not we agree that Arundel's efforts sharply curtailed the writing of new texts, his actions seem to have reinvigorated the market for fourteenthcentury books by driving lay readers back to their old favorites..$^{98}$ The Prick of Conscience Window may even present a case in point, as Richard Marks has suggested. ${ }^{99}$ But the window is not simply a testament to the ongoing popularity of a favorite northern poem. Beyond illustrating the fifteen signs, the window shapes its viewers' understanding of them by pairing them with images of the Last Judgment. The window inspires fear, as does the poem, but it ultimately urges viewers to turn from fear to worship-to turn, more particularly, to the parish of All Saints, North Street. To be sure, the Prick of Conscience Window reclaims and preserves a decades-old poem, but it does so by interpolating it into the parish and, in so doing, reframing the parish as a textual community. By engaging with the poem in this way, the window works toward redefining the reading and interpretation of the Prick of Conscience as a parochial enterprise, one that encompasses both the laity and the priesthood, and one that will, in drawing Christians to the parish, lead them together to salvation at the end of days.

97. Watson, "Censorship and Cultural Change," 826. Gillespie urges scholars to think more deeply about the "strength and resourcefulness" of vernacular theology, particularly "its ability to recombine a wide spectrum of cognate theological discourses robustly and flexibly available in the mother tongue." "Vernacular Theology," 403.

98. The Prick of Conscience, immediately popular when it first circulated in the middle of the fourteenth century, would remain "staple reading" for the next century and beyond. Watson, "Censorship and Cultural Change," 835.

99. Noting the increasing use of vernacular verse and prose in the "image-cum-text of parish churches," Marks suggests that the Prick of Conscience Window might be an "early example" of the sentiment that what had already been written in the vernacular "could unproblematically stay in the vernacular." "Picturing Word and Text," 182-83. 


\section{EPILOGUE}

\section{How Do I Save My Soul?}

\footnotetext{
Timan
}

n concluding this book, I am reminded of one of the central questions of Piers Plowman. Looking out over the field of folk, the dreamer wonders what it all means and what, even more importantly, he is supposed to do. Tell me, he asks Holy Church, "How I may save my soule." I have argued throughout this book that a wide variety of vernacular devotional literature insists upon the importance of collective parochial worship. Sermonists and poets often turn to parochial space, fabric, and ritual in order to understand and conceptualize the layperson's lifelong journey to salvation. Rooted in the parish, the lay religious experience was characterized by local rituals that emphasized the creation and preservation of parochial community: font and grave, both emblems of parochial identity in sermon exempla and poetry, played an important role in assembling and shaping the parish. And as we saw in chapter 2, although penance is often understood as an individual practice, it was essential to the collective ritual life of the parish. The very process of getting oneself

1. Langland, Vision of Piers Plowman: A Critical Edition of the B-Text, ed. Schmidt, 1.84 . 
to heaven is often conceptualized through tropes-ascent and procession, for example, or cooperative agricultural labor-that foreground the shared nature of the endeavor. Indeed, although medieval Christians understood that they would be judged by God individually at the end of time, they also considered the long process of achieving salvation to be a collective enterprise rooted in parochial practice. As Emily Steiner has recently observed, even though Piers asks how he might go about saving his own soul, "community is at the heart of this desire to be saved, and the ethics of association articulates the link between being saved and doing well." ${ }^{2}$ We have certainly seen such a link in the Prick of Conscience Window, in which fear of the end prompts viewers to kneel together before the altar in the here and now.

As I have shown throughout this book, medieval texts and images often celebrate the ideal of collective parochial worship. We might recall, for example, the direct relationship between penance and parochial community in Handlyng Synne, in which a cleanly confessed layman, now free of the devil, blends in with his fellow parishioners and becomes invisible to his former captor. Or we might think of the De profundis exemplum from Mirk's Festial, in which a churchyard full of risen souls comes to the aid of the living layman who prayed for them daily. Parishioners come together in a spirit of mutual help and a shared commitment to penance. They kneel side by side in prayer, and they walk one before the other in Eastertide processions that celebrate their collective triumph over the devil. The visual rhetoric of the parishthe axis formed by font, altar, and Last Judgment mural, for example-provides further articulation of the powerful link between parochial worship and membership in the eternal community of the saved.

I have suggested that what motivates my diverse collection of texts and images is their orientation toward the parish-they are the images parishioners saw, the stories they heard from the pulpit, and the prayers and tenets they learned. Even as these texts and images promote the ideal of collective worship, however, they register a certain anxiety about the parish and its vulnerability to sin and violence. And if the poems and exempla I have considered in this book emphasize collective salvation, they also admit that not everyone will be saved: some will be deleted from the book of life, their bodies dramatically ejected from humble churchyard graves. These texts are also unfailingly attentive to the fact that, even for those who do achieve salvation, the task will not be an easy one. As we saw in chapter 3, when the fourteenthcentury Shoreham poet describes the arduous climb to salvation, he reminds readers that heaven is high and that laypeople are heavy with sin. The road

2. Steiner, Reading "Piers Plowman," 60. 
to salvation is often depicted as fraught with hesitation, slothful inertia, even abject failure.

This is perhaps especially true in Piers Plowman. Although the poem begins and ends with the dreamer wandering on his own, it makes elliptical turns back to parochial ritual as it moves from one episode to the next. But if Piers Plowman is a poem about the desire to be saved and about the central role that community plays in helping Christians achieve salvation, it is also a poem about not quite or not fully getting to the parish-a poem about getting there, only to fall asleep in the middle of it all. ${ }^{3}$ How do I save my soul? The answer seems to be, at least in part, by trying and failing, again and again. Frustration and difficulty are inherent to the process. Devotional literature holds up the ideal of parochial worship, but it also attends to the reality of spiritual fits and starts. That it does so is, of course, in keeping with the very theology of penance. The life worthy of salvation is not necessarily the perfect life but the actively penitential life-a lifetime of confessing one's sins, of struggling to redirect one's movement back to God after a swerve off course, of climbing back up the ladder after a fall.

In seeking to answer a question that was on every layperson's mind, Middle English texts locate the arduous process of getting saved in the parish and in the work that parishioners undertake there together. Even as they encourage readers and listeners to engage in self-reflection and self-reform, and even as they attend to the inherent difficulty of getting saved, late medieval authors ultimately understand the parish, its spaces, and its rituals to be the nexus of these concerns. The parish mattered because it offered a framework for negotiating a complex web of relationships between individual, community, and God. And as a place where past, present, and future came together, the parish promised an ongoing relationship between the living and the dead and positioned the here and now of the local parish in the long trajectory of eschatological time.

Middle English devotional writing looks different when we pay close attention to the parish. Sermon exempla, liturgical texts, and instructional handbooks-the parish-oriented texts at the core of this book-have often been sidelined in discussions of late medieval vernacular theology. Their sustained interest in collective worship and in the cultivation of lay spiritual community makes it clear that the parish mattered and that it mattered, moreover, at a time when laypeople were increasingly seeking out more personalized forms of devotion. Many scholars have seen the parish as a victim of "privatiza-

3. As Zeeman has suggested, Piers Plowman unfurls in "cycle[s] of deprivation and desire." "Piers Plowman" and the Medieval Discourse of Desire, 16. 
tion," to borrow from Colin Richmond's oft-cited article on fifteenth-century religious culture. Pews fostered privacy and "non-participation," Richmond argues; the laypeople who occupied them "insulated themselves against communal religion," in part by turning their attention to the books of hours that they brought with them to church. ${ }^{4}$ As I mentioned in the previous chapter, Eamon Duffy has argued against such a narrow view of books of hours. While Richmond associates primers with isolation, Duffy suggests that, by virtue of their liturgical content, these books fostered more active participation in the ritual life of the parish. ${ }^{5}$

A report written by a Venetian nobleman who visited England in 1500 offers a rare bit of insight into the relationship between primers and the parish in late medieval religious culture. In A Relation, or Rather a True Account, of the Island of England, we learn that English laypeople "attend Mass every day" and that women tend to come to church with books of hours: they "take the office of our Lady with them," the Venetian traveler observes, "and with some companion recite it in the church, verse by verse, in a low voice, after the manner of churchmen." It is no surprise that a visitor to England would notice laywomen's penchant for primers. Beyond observing the popularity of books of hours, however, the Venetian visitor also acknowledges their association with the parish and its liturgy; women bring the books with them to church and use them during the service. Books of hours would seem to be much more closely connected to the collective context of parochial worship than we have made them out to be. We need look no further than the Office of the Dead which, in numerous primers, is accompanied by an illustration of church practice-a funeral scene in the nave, for example, or a churchyard burial. As Duffy reminds us, these books are used both privately (at home) and publicly (at church). In addition to this dual function, however, to what extent might images of church ritual allow the user to engage with collective worship, even when using the book in a more private, domestic context? To what extent do they offer a portable extension of the parish and its practices, a kind of parish away from the parish?

In addition to shedding light on the complex function of books of hours, the Venetian visitor's account also attests more generally to the powerful draw of the parish. Although they attend mass daily, he explains, English laypeople "always hear Mass on Sunday in their parish church."' And yet,

4. Richmond, "Religion and the Fifteenth-Century English Gentleman," 198-99.

5. Duffy, Marking the Hours, 60.

6. Relation ... of the Island of England, 23 .

7. Ibid., 23 . 
even as the parish continues to play a central role in the ritual lives of laypeople, the anonymous report positions it in the context of an evolving religious climate, one in which laypeople engage in modes of worship that traffic in both the communal and the individual. The Venetian nobleman's observation that English laypeople "always" attend Sunday mass in their parish churches suggests, of course, that laypeople had a number of options when it came to church attendance and that many of them were attending masses elsewhere during the week. Indeed, we have already seen how the parish itself could offer its members a range of devotional experiences; at All Saints, North Street, parishioners understood and expressed their piety in a variety of ways-through participation in the collective liturgy of the Mass, for example, but also by way of the more personalized chapel, reading lectern, and family book. In praising the English for their regular church attendance, the Venetian traveler also hints at the complexity of English piety at the close of the fifteenth century: "There are," he writes, "many who have various opinions concerning religion."

I have argued throughout this book that a wide variety of fourteenthcentury poems, sermons, and handbooks emphasize the importance of collective devotion and the idea that salvation is achieved through the ritual life of the parish. In attending to the parish in Middle English religious writing, this book has sought to understand how and why collective parochial worship mattered to laypeople and how it shaped their experience of devotion, their understanding of salvation, and their conception of themselves as Christians. Recent work on fifteenth-century religious culture suggests that the parish was at the heart of several heated religious debates-about the spiritual value of parish paintings and about the nature of the sacraments, for example, and even about the value of the material church as a whole. ${ }^{9}$ In what ways would the collective contexts of devotion continue to shape lay spiritual identity and inform laypeople's understanding of salvation and of the relationship between past, present, and future? To what extent was parochial worship itself an object of scrutiny? Although the Venetian visitor himself seems to register something of the changing religious climate, his description of English laypeople flocking to their parish churches on Sundays certainly emphasizes the staying power of parochial worship. His observations bring to mind the opening lines of What the Church Betokeneth, a contemporary vernacular treatise on the church and its rituals: "The churche betokenyth ij things," the author writes. Much more than "the place where the seruyce of God is said

8. Ibid., 23.

9. See especially Gayk, Image, Text, and Religious Reform. 
and songe," it is "pe gadryng place togeder of alle true cristen people." And in this gathering place, he continues, they "serve God with one wylle in loue and charyte. ${ }^{{ }^{10}}$ For the Venetian visitor and the author of What the Church Betokeneth-both writing at the very end of the fifteenth century-the English parish church remains, above all, a ritual space in which the Christian community constitutes its best, most ideal self.

10. What the Church Betokeneth, 87 (lines 1-4). See also Varnam's recent discussion of this text and its representation of the church as "a space of ritual practice." "Church," 303 . 


\section{B IB LIOGRAPHY}

\section{Primary Sources}

Augustine. De Doctrina Christiana. Ed. J. Martin. In Aureli Augustini Opera. Corpus Christianorum, Series Latina 32. Turnhout: Brepols, 1962.

- Sancti Augustini Opera: Enarrationes in Psalmos 1-50. Ed. Clemens Weidmann. Wien: Verlag der Österreichischen Akademie der Wissenschaften, 2003 .

Sancti Augustini Opera: Enarrationes in Psalmos 101-50. Ed. Franco Gori. Wien: Verlag der Österreichischen Akademie der Wissenschaften, 2001.

Bernard of Clairvaux. Bernard of Clairvaux on the Song of Songs. Trans. Kilian Walsh and Irene M. Edmonds. 4 vols. Kalamazoo: Cistercian Publications, 1979.

Sancti Bernardi Opera. Ed. Jean Leclerq, C. H. Talbot and Henri Rochais. 8 vols. Rome: Editiones Cisterciensis, 1956.

The Book of Margery Kempe. Ed. Barry Windeatt. London: Longman, 2000.

The Book of Vices and Virtues: A Fourteenth-Century English Translation of the "Somme Le Roi" of Lorens D'Orléans. Ed. W. Nelson Francis. EETS o.s. 217 (1942).

Chaucer, Geoffrey. The Canterbury Tales. Ed. Jill Mann. London: Penguin, 2005.

Councils and Synods: With Other Documents Relating to the English Church. Ed. F. M. Powicke and C. R. Cheney. 2 vols. Oxford: Clarendon Press, 1964.

Cursor Mundi. Ed. Richard Morris. EETS o.s. 57, 59, 62, 66, 68, 99, 101 (1874-93).

Decrees of the Ecumenical Councils. Vol. 1, Nicaea 1-Lateran V. Ed. Norman Tanner. Washington, DC: Georgetown University Press, 1990. 
Disciplinary Decrees of the General Councils: Text, Translation, and Commentary. Ed. H. J. Schroeder. St. Louis: Herder Book Co., 1937.

The English Register of Godstow Nunnery. Ed. Andrew Clark. EETS o.s. 129 (1911).

FitzRalph, Richard. Defensio Curatorum. Trans. John Trevisa. In Dialogus inter Militem et Clericum, ed. A. J. Perry. EETS o.s. 167 (1925).

Jacob's Well: An Englisht Treatise on the Cleansing of Man's Conscience. Ed. Arthur Brandeis. EETS o.s. 115 (1900).

Langland, William. Piers Plowman: A Parallel-Text Edition of the A, B, C and Z Versions. Rev. ed. Ed. A. V. C. Schmidt. Kalamazoo: Medieval Institute Publications, 2011.

- Piers Plowman: The A version. Rev. ed. Ed. George Kane. London: Athlone Press, 1988.

- Piers Plowman: The B Version. Rev. ed. Ed. George Kane and E. Talbot Donaldson. London: Athlone Press, 1975.

C. Piers Plowman: The Prologue and Passus I-VII of the B Text as Found in Bodleian MS Laud. 581. Ed. J. A. W. Bennett. Oxford: Clarendon, 1972.

—. Piers the Ploughman. Trans. J. F. Goodridge. Harmondsworth: Penguin, 1959.

- The Vision of Piers Plowman: A Critical Edition of the B-Text Based on Trinity College Cambridge MS B.15.17. 2nd ed. Ed. A. V. C. Schmidt. London: Everyman, 1995.

- The Vision of William Concerning Piers the Plowman in Three Parallel Texts. Ed. Walter J. Skeat. Oxford: Oxford University Press, 1886.

The Lay Folks Mass Book. Ed. Thomas Frederick Simmons. EETS o.s. 71 (1879).

The Lay Folks' Catechism. Ed. Thomas Frederick Simmons and Henry Edward Nolloth. EETS o.s. 118 (1901).

Mannyng, Robert. Handlyng Synne. Ed. Idelle Sullens. Binghamton: Medieval and Renaissance Texts and Studies, 1983.

- Handlyng Synne, A.D. 1303, with Those Parts of the Anglo-French Treatise on Which It Was Founded, William of Wadington's "Manuel des Pechiez." Ed. F. J. Furnivall. EETS o.s. 119, 123 (1901, 1903).

Memoriale Credencium: A Late Middle English Manual of Theology for Lay People; Edited from Bodley MS Tanner 201. Ed. J. H. L. Kengen. Nijmegen: University of Nijmegen, 1979.

Middle English Sermons, Edited from British Museum Royal 18 B.xxiii. Ed. Woodburn O. Ross. EETS o.s. 209 (1940).

Mirk, John. Instructions for Parish Priests. Ed. Edward Peacock. EETS o.s. 31 (1868).

—. John Mirk's Festial: Edited from British Library MS Cotton Claudius A.II. Ed. Susan Powell. EETS o.s. 334-35 (2009-11).

—. John Mirk's Instructions for Parish Priests. Ed. Gillis Kristensson. Lund: Gleerup, 1974.

- The Northern Homily Cycle. Ed. Anne B. Thompson. Kalamazoo: Medieval Institute Publications, 2008.

The Northern Homily Cycle: The Expanded Version in MSS Harley 4196 and Cotton Tiberius E.VII. Ed. Saara Nevanlinna. 3 vols. Mémoires de la Société Néophilologique de Helsinki 38, 41, 43 (1972-84).

Of Shrifte and Penance: The Middle English Prose Translation of "Le Manuel des Péchés." Trans. Klaus Bitterling. Heidelberg: Universitätsverlag, C. Winter, 1998.

The Piers Plowman Tradition: A Critical Edition of Pierce the Ploughman's Crede, Richard the 
Redeless, Mum and the Sothsegger, and the Crowned King. Ed. Helen Barr. London: J. M. Dent, 1993.

The Poems of William of Shoreham. Ed. Matthias Konrath. EETS o.s. 86 (1902).

Prick of Conscience. [See Richard Morris's Prick of Conscience.]

The Prymer, or Lay Folks' Prayer Book. Ed. Henry Littlehales. EETS o.s. 105 (1895).

The Register of Henry Chichele. Ed. E. F. Jacob. Oxford: Clarendon Press, 1945.

The Register of John Chandler, Dean of Salisbury, 1404-1407. Ed. T. C. B. Timmins. Wiltshire Record Society 39 (1983).

A Relation, or Rather a True Account, of the Island of England. Trans. Charlotte Augusta Sneyd. London: The Camden Society, 1847.

A Repertorium of Middle English Prose Sermons, Part 2: London, British Library (Arundel) to London, Westminster Abbey Library. Ed. Veronica O'Mara and Suzanne Paul. Turnhout: Brepols, 2007.

Richard Morris's Prick of Conscience: A Corrected and Amplified Reading Text. Ed. Ralph Hanna and Sarah Wood. EETS o.s. 342 (2013).

Selected English Works of John Wyclif. Ed. Thomas Arnold. 3 vols. Oxford: Clarendon Press, 186971.

Six Ecclesiastical Satires. Ed. James M. Dean. Kalamazoo: Western Institute Publications, 1991.

The South English Legendary. Ed. Charlotte D'Evelyn and Anna Jean Mill. EETS 235, 236, 244 (1956-59).

Speculum Sacerdotale. Ed. Edward H. Weatherly. EETS o.s. 200 (1936).

Voragine, Jacobus de. The Golden Legend: Readings on the Saints. Trans. William Granger Ryan. 2 vols. Princeton: Princeton University Press, 1993.

- Legenda Aurea, Vulgo Historia Lombardica Dicta, ad Optimorum Librorum Fidem Recensuit Dr. Th. Graesse. Ed. Theodor Graesse. Repr. Osnabrück: Otto Zeller Verlag, 1965.

Waddington, William. Manuel des Péchés. [See Mannyng, Handlyng Synne, ed. Furnivall.]

Walter of Henley and Other Treatises of Estate Management and Accounting. Ed. and trans. Dorothea Oschinsky. Oxford: Clarendon Press, 1971.

What the Church Betokeneth. In Supplementary Lives in Some Manuscripts of the Gilte Legende. Ed. Richard Hamer and Vida Russell. 85-128. EETS o.s. 315 (2000).

York Mystery Plays: A Selection in Modern Spelling. Ed. Richard Beadle and Pamela M. King. Oxford: Oxford University Press, 1995.

\section{Secondary Sources}

Abbott, Arthur. History of the Parishes of Irnham and Corby. Lincoln: J. W. Ruddock and Sons, 1927.

Aers, David. "Justice and Wage-Labor after the Black Death: Some Perplexities for William Langland." In The Work of Work: Servitude, Slavery, and Labor in Medieval England, ed. Allen J. Frantzen and Douglas Moffat. 169-90. Glasgow: Cruithne Press, 1994.

- Salvation and Sin: Augustine, Langland, and Fourteenth-Century Theology. Notre Dame: University of Notre Dame Press, 2009. 
Alford, John A. "Piers Plowman": A Glossary of Legal Diction. Cambridge: D. S. Brewer, 1988.

Allen, Elizabeth. False Fables and Exemplary Truth in Later Middle English Literature. New York: Palgrave Macmillan, 2005.

Allen, Hope Emily. Writings Ascribed to Richard Rolle, Hermit of Hampole, and Materials for His Biography. New York: Modern Language Association, 1927.

Anderson, Gary A. Charity: The Place of the Poor in Biblical Tradition. New Haven: Yale University Press, 2013.

Ashley, Kathleen. "Introduction: The Moving Subjects of Processional Performance." In Moving Subjects: Processional Performance in the Middle Ages and Renaissance, ed. Kathleen Ashley and Wim Hüsken. 7-34. Amsterdam: Rodopi, 2001.

Atchley, Clinton. “The 'Wose' of Jacob's Well: Text and Context.” Ph.D. diss., University of Washington, 1998.

Ault, W. O. "By-Laws of Gleaning and the Problems of Harvest." Economic History Review 14, no. 2 (1961): 210-17.

"Manor Court and Parish in Fifteenth-Century England: A Study of Village By-Laws." Speculum 42, no. 1 (1967): 53-67.

- Open-Field Farming in Medieval England: A Study of Village By-Laws. London: George Allen and Unwin, 1972.

—. "Open-Field Husbandry and the Village Community: A Study of Agrarian By-Laws in Medieval England." Transactions of the American Philosophical Society 55, no. 7 (October 1965): 1-102.

. “Some Early Village By-Laws." English Historical Review 45 (1930): 208-31.

“The Vill in Medieval England." Proceedings of the American Philosophical Society 126 (1982): 188-211.

—. "Village By-Laws by Common Consent." Speculum 29, no. 2 (1954): 378-94.

Backhouse, Janet. The Luttrell Psalter. London: British Library, 1989.

Baker, Denise N. "From Plowing to Penitence: Piers Plowman and Fourteenth-Century Theology." Speculum 55, no. 4 (1980): 715-25.

Banks, Robert. "'Walking' as a Metaphor of the Christian Life: The Origins of a Significant Pauline Usage." In Perspectives on Language and Text, ed. Edgar W. Conrad and Edward G. Newing. 303-13. Winona Lake, IN: Eisenbrauns, 1987.

Bardsley, Sandy. “Women's Work Reconsidered: Gender and Wage Differentiation in Late Medieval England." Past and Present 165 (1999): 3-29.

Barney, Stephen. The Penn Commentary on "Piers Plowman." Vol. 5, C Passus 20-22; B Passus 18-20. Philadelphia: University of Pennsylvania Press, 2006.

—. "The Plowshare of the Tongue: The Progress of a Symbol from the Bible to Piers Plowman.” Mediaeval Studies 35 (1973): 261-93.

Barnwell, P. S. “'Four Hundred Masses on the Four Fridays Next after my Decease': The Care of Souls in Fifteenth-Century All Saints,' North Street, York." In Mass and Parish in Late Medieval England: The Use of York, ed. P. S. Barnwell, Claire Cross, and Ann Rycraft. 57-89. Reading: Spire Books, 2005.

Barr, Helen. Signes and Sothe: Language in the "Piers Plowman" Tradition. Cambridge: D. S. Brewer, 1994.

- Socioliterary Practice in Late Medieval England. Oxford: Oxford University Press, 2001. 
Beckwith, Sarah. Signifying God: Social Relation and Symbolic Act in the York Corpus Christi Plays. Chicago: University of Chicago Press, 2001.

Bennett, H. S. Life on the English Manor: A Study of Peasant Conditions, 1150-140o. Cambridge: Cambridge University Press, 1960.

Bennett, Michael. "Spiritual Kinship and the Baptismal Name in Traditional European Society." In Principalities, Powers, and Estates: Studies in Medieval and Early Modern Government and Society, ed. L. O. Frappell. 1-13. Adelaide: Adelaide University Press, 1980. Repr. in Studies on the Personal Name in Later Medieval England and Wales, ed. Dave Postles and Joel T. Rosenthal. 115-46. Kalamazoo: Medieval Institute Publications, 2006.

Benson, C. David. Public "Piers Plowman": Modern Scholarship and Late Medieval English Culture. University Park: Pennsylvania State University Press, 2004.

Benson, C. David, and Lynne S. Blanchfield, eds. The Manuscripts of "Piers Plowman": The BVersion. Cambridge: D. S. Brewer, 1997.

Binski, Paul. "The English Parish Church and its Art in the Later Middle Ages: A Review of the Problem." Studies in Iconography 20 (1999): 1-25.

- Medieval Death: Ritual and Representation. London: British Museum, 1996.

Biscoglio, Frances M. “'Unspun' Heroes: Iconography of the Spinning Woman in the Middle Ages." Journal of Medieval and Renaissance Studies 25 (1995): 159-76.

Boboc, Andreea. "Lay Performances of Work and Salvation in the York Cycle." Comparative Drama 43, no. 2 (2009): 257-71.

Bond, Francis. An Introduction to English Church Architecture from the Eleventh to the Sixteenth Century. 2 vols. London: Oxford University Press, 1913.

Bossy, John. "Blood and Baptism: Kinship, Community and Christianity in Western Europe from the 14th-17th Centuries." Studies in Church History 10 (1973): 129-43.

—. "The Mass as a Social Institution, 1200-1700." Past and Present 100 (1983): 29-61.

_. "The Social History of Confession in the Age of the Reformation." Transactions of the Royal Historical Society 25 (1975): 21-38.

Bowen, Lee. “The Tropology of Mediaeval Dedication Rites." Speculum 16, no. 4 (1941): 469-79.

Boyle, Leonard E. "The Fourth Lateran Council and Manuals of Popular Theology." In The Popular Literature of Late Medieval England, ed. Thomas J. Heffernan. 30-43. Knoxville: University of Tennessee Press, 1985.

Boynton, Susan. "Work and Play in Sacred Music and its Social Context, c. 1050-1250." Studies in Church History 37 (2002): 57-79.

Brady, Niall. "The Gothic Barn of England: Icon of Prestige and Authority." In Technology and Resource Use in Medieval Europe: Cathedrals, Mills, and Mines, ed. Elizabeth Bradford Smith and Michael Wolfe. 76-105. Aldershot: Ashgate, 1997.

Braekman, W. L. "Bollard's Middle English Book of Planting and Grafting and Its Background." Studia Neophilologica 57 (1985): 19-39.

Brantley, Jessica. Reading in the Wilderness: Private Devotion and Public Performance in Late Medieval England. Chicago: University of Chicago Press, 2007.

Brigden, Roy. Ploughs and Ploughing. Princes Risborough: Shire Publications, 1984.

Brigden, Susan. "Religion and Social Obligation in Early Sixteenth-Century London." Past and Present 103 (1984): 67-112.

Briggs, Charles F. "Literacy, Reading, and Writing in the Medieval West." Journal of Medieval History 26, no. 4 (2000): 397-420. 
Brodman, James William. Charity and Religion in Medieval Europe. Washington, DC: Catholic University of America Press, 2009.

Brown, Andrew D. Popular Piety in Late Medieval England: The Diocese of Salisbury, 1250-1550. Oxford: Clarendon Press, 1995.

Brown, Michelle P. The Holkham Bible Picture Book: A Facsimile. London: British Library, 2007.

—. The Luttrell Psalter: A Facsimile. London: British Library, 2006.

Bryan, Jennifer. Looking Inward: Devotional Reading and the Private Self in Late Medieval England. Philadelphia: University of Philadelphia Press, 2008.

Buhrer, Eliza. "From Caritas to Charity: How Loving God Became Giving Alms." In Poverty and Prosperity in the Middle Ages and the Renaissance, ed. Cynthia Kosso and Anne Scott. 113-28. Turnhout: Brepols, 2012.

Burgess, Clive. "'A Fond Thing Vainly Invented': An Essay on Purgatory and Pious Motive in Later Medieval England." In Parish, Church and People: Local Studies in Lay Religion, 1350-1750, ed. S. J. Wright. 56-84. London: Hutchison, 1988.

_ "For the Increase of Divine Service': Chantries in the Parish in Late Medieval Bristol." Journal of Ecclesiastical History 36, no. 1 (1985): 46-65.

—. "'Longing to Be Prayed For': Death and Commemoration in an English Parish in the Later Middle Ages." In The Place of the Dead: Death and Remembrance in Late Medieval and Early Modern Europe, ed. Bruce Gordon and Peter Marshall. 44-65. Cambridge: Cambridge University Press, 2000.

Burgess, Clive, and Eamon Duffy, eds. The Parish in Late Medieval England. Donington: Shaun Tyas, 2006.

Bushnell, Rebecca. Green Desire: Imagining Early Modern Gardens. Ithaca: Cornell University Press, 2003.

Cahn, Walter. "Ascending to and Descending from Heaven: Ladder Themes in Early Medieval Art." In Santi e demoni nellalto medioevo occidentale (secoli V-XI). 697-724. Spoleto: Centro italiano di studi sull'Alto Medioevo, 1989.

Caiger-Smith, A. English Medieval Mural Paintings. Oxford: Clarendon Press, 1963.

Camille, Michael. "Labouring for the Lord: The Ploughman and the Social Order in the Luttrell Psalter." Art History 10 (1981): 423-54.

- Mirror in Parchment: The Luttrell Psalter and the Making of Medieval England. Chicago: University of Chicago Press, 1998.

Carruthers, Mary. "Allegory without the Teeth: Some Reflections on Figural Language in Piers Plowman." Yearbook of Langland Studies 19 (2005): 27-43.

—_. "Imaginatif, Memoria, and 'The Need for Critical Theory' in Piers Plowman Studies." Yearbook of Langland Studies 9 (1995): 103-20.

—. The Search for St. Truth: A Study of Meaning in "Piers Plowman." Evanston: Northwestern University Press, 1973.

Chickering, Howell. "Rhetorical Stimulus in the Prick of Conscience." In Medieval Paradigms: Essays in Honor of Jeremy Duquesnay Adams, ed. Stephanie Hayes-Healey. 191-230. New York: Palgrave Macmillan, 2005.

Ciabbatoni, Francesco. "Dante's Organa: The Comedy from Unholy Racket to Sacred Music." Italian Quarterly 43 (2006): 5-23.

Clanchy, Michael. "Did Mothers Teach Their Children to Read?" In Motherhood, Religion, and 
Society in Medieval Europe, 400-140o: Essays Presented to Henrietta Leyser, ed. Conrad Leyser and Lesley Smith. 129-53. Farnham: Ashgate, 2011.

Cole, Andrew. "Scribal Hermeneutics and the Genres of Social Organization in Piers Plowman." In The Middle Ages at Work: Practicing Labor in Late Medieval England, ed. Kellie Robertson and Michael Uebel. 179-206. New York: Palgrave MacMillan, 2004.

. "Trifunctionality and the Tree of Charity: Literary and Social Practice in Piers Plowman." English Literary History 72 (1995): 1-27.

Coleman, Joyce, Mark Cruse, and Kathryn A. Smith, eds. The Social Life of Illumination: Manuscripts, Images, and Communities in the Late Middle Ages. Turnhout: Brepols, 2013.

Connolly, Daniel K. The Maps of Matthew Paris: Medieval Journeys through Space, Time and Liturgy. Woodbridge: Boydell, 2009.

Cook, G. H. The English Mediaeval Parish Church. London: Phoenix House, 1954.

Cooper, Helen. "Gender and Personification in Piers Plowman." Yearbook of Langland Studies 5 (1990): 31-48.

Cox, J. Charles. Parish Registers of England. London: Methuen, 1910.

Crane, Susan. "The Writing Lesson of 1381." In Chaucer's England: Literature in Historical Context, ed. Barbara Hanawalt. 201-21. Minneapolis: University of Minnesota Press, 1992.

Crassons, Kate. The Claims of Poverty: Literature, Culture, and Ideology in Late Medieval England. Notre Dame: University of Notre Dame Press, 2010.

Cullum, Patricia, and Jeremy Goldberg. "How Margaret Blackburn Taught Her Daughters: Reading Devotional Instruction in a Book of Hours." In Medieval Women: Texts and Contexts in Late Medieval Britain, ed. Jocelyn Wogan-Browne. 217-36. Turnhout: Brepols, 2000.

Cullum, P. H. "'Yf Lak of Charyte Be Not Ower Hynderawnce': Margery Kempe, Lynn, and the Practice of the Spiritual and Bodily Works of Mercy." In A Companion to the "Book of Margery Kempe," ed. John A. Arnold and Katherine J. Lewis. 177-93. Cambridge: D. S. Brewer, 2004.

Cylkowski, David G. "A Middle English Treatise on Horticulture: Godfridus Super Palladium." In Popular and Practical Science of Medieval England, ed. Lister M. Matheson. 301-29. East Lansing: Colleagues Press, 1994.

Dallen, James. The Reconciling Community: The Rite of Penance. New York: Pueblo Publishing, 1986.

Daniell, Christopher. Death and Burial in Medieval England. London: Routledge, 1997.

Davidson, Clifford. "The Signs of Doomsday in Drama and Art." Historical Reflections 26, no. 2 (2000): $235-45$.

Davies, J. G. The Architectural Setting of Baptism. London: Barrie and Rockliff, 1962.

Davis, Natalie Zemon. "Some Tasks and Themes in the Study of Popular Religion." In The Pursuit of Holiness in Late Medieval and Renaissance Religion: Papers from the University of Michigan Conference, ed. Charles Trinkhaus and Heiko A. Oberman. 307-36. Leiden: Brill, 1974.

Davis, Rebecca A. "Spiritual Charity and the Logic of Conversion in Piers Plowman." Yearbook of Langland Studies 19 (2005): 59-79.

Davlin, Mary Clemente. "Devotional Postures in Piers Plowman B, with an Appendix on Divine Postures." The Chaucer Review 42, no. 2 (2007): 161-79.

. A Game of Heuene: Word Play and the Meaning of "Piers Plowman" B. Cambridge: D. S. Brewer, 1989. 
“Kynde Knowynge as a Major Theme in Piers Plowman B." Review of English Studies 22 (1971): 1-19.

Dinn, Robert. "'Monuments Answerable to Mens Worth': Burial Patterns, Social Status and Gender in Late Medieval Bury St. Edmunds." Journal of Ecclesiastical History 46, no. 2 (1995): 237-55.

Dobson, Barrie. "Citizens and Chantries in Late Medieval York." In Church and City, 100-1500: Essays in Honour of Christopher Brooke, ed. David Abulafia, M. J. Franklin, and Miri Rubin. 267-84. Cambridge: Cambridge University Press, 1992.

Dolan, T. P. “English and Latin Versions of FitzRalph's Sermons.” In Latin and Vernacular: Studies in Late Medieval Texts and Manuscripts, ed. A. J. Minnis. 27-37. Cambridge: D. S. Brewer, 1989.

Dudley, Martin, and Jill Pinnock. "Rites of Penance and Reconciliation." In Confession and Absolution, ed. Martin Dudley and Geoffrey Rowell. 181-205. Collegeville: The Liturgical Press, 1990.

Duffy, Eamon. “The Dynamics of Pilgrimage in Late Medieval England.” In Pilgrimage: The English Experience from Becket to Bunyan, ed. Colin Morris and Peter Roberts. 164-77. Cambridge: Cambridge University Press, 2002.

—. "Late Medieval Religion." In Gothic: Art for England 1400-1547, ed. Richard Marks and Paul Williamson. 56-67. London: Victoria and Albert Publications, 2003.

- Marking the Hours: The English People and Their Prayers, 1240-1570. New Haven: Yale University Press, 2006.

. The Stripping of the Altars: Traditional Religion in England, 1400-1580. New Haven: Yale University Press, 1992.

Duggan, Lawrence G. "Was Art Really the 'Book of the Illiterate'?" In Reading Images and Texts: Medieval Images and Texts as Forms of Communication, ed. Marielle Hageman and Marco Mostert. 63-107. Turnhout: Brepols, 2005.

Dyas, Dee. Pilgrimage in Medieval English Literature, 700-1500. Cambridge: D. S. Brewer, 2001.

Dyer, Christopher. “The English Medieval Village Community and Its Decline." Journal of British Studies 33 (1994): 407-29.

- Making a Living in the Middle Ages: The People of Britain, 850-1520. New Haven: Yale University Press, 2002.

_. "Piers Plowman and Plowmen: A Historical Perspective." Yearbook of Langland Studies 8 (1994): 155-76.

. "Power and Conflict in the Medieval English Village." In Medieval Villages: A Review of Current Work, ed. Della Hooke. Oxford University Committee for Achaeology, monograph no. 5. 27-32. Oxford: University of Oxford, 1985.

Edden, Valerie. “The Devotional Life of the Laity in the Late Middle Ages." In Approaching Medieval English Anchoritic and Mystical Texts, ed. Dee Dyas, Valerie Edden, and Roger Ellis. 38-49. Cambridge: D. S. Brewer, 2005.

Edwards, Anthony S. G. “Middle English Inscriptional Verse Texts.” In Texts and Their Contexts: Papers from the Early Book Society, ed. V. J. Scattergood and Julia Boffey. 26-43. Dublin: Four Courts Press, 1997.

Edwards, John. “Trotton's 'Abbreviated' Doom.” Sussex Archaeological Collections 123 (1985): 115225 .

Elich, Tom. "Communal Reconciliation in Pre-Reformation England: Lessons from the SevenSacraments Fonts of East Anglia." Studia Liturgica 36 (2006): 138-65. 
Emmerson, Richard K., and P. J. P. Goldberg. “'The Lord Geoffrey Had Me Made': Lordship and Labour in the Luttrell Psalter." In The Problem of Labour in Fourteenth Century England, ed. James Bothwell, P. J. P. Goldberg, and W. M. Ormrod. 43-63.Woodbridge: York Medieval Press, 2000.

Fiero, Gloria K. "Death Ritual in Fifteenth-Century Manuscript Illumination." Journal of Medieval History 10 (1984): 271-94.

Finke, Laurie A. "Truth's Treasure: Allegory and Meaning in Piers Plowman." In Medieval Texts and Contemporary Readers, ed. Laurie A. Finke and Martin B. Schichtman. 51-68. Ithaca: Cornell University Press, 1987.

Fisher, J. D. C. Christian Initiation: Baptism in the Medieval West. London: SPCK, 1965.

Fitzgibbons, Moira. "Disruptive Simplicity: Gaytryge's Translation of Archbishop Thoresby's Injunctions." In The Vernacular Spirit: Essays on Medieval Religious Literature, ed. Renate Blumenfeld-Kosinski, Duncan Robertson, and Nancy Bradley Warren. 39-58. New York: Palgrave, 2002.

. "Enabled and Disabled 'Myndes' in The Prick of Conscience." In Medieval Poetics and Social Practice: Responding to the Work of Penn R. Szittya, ed. Seeta Chaganti. 72-94. New York: Fordham University Press, 2012.

"Jacob's Well and Penitential Pedagogy." Studies in the Age of Chaucer 27 (2005): 213-37.

Flanigan, C. Clifford. "The Moving Subject: Medieval Liturgical Processions in Semiotic and Cultural Perspective." In Moving Subjects: Processional Performance in the Middle Ages and the Renaissance, ed. Kathleen M. Ashley and Wim N. M. Hüsken. 35-51. Amsterdam: Rodopi, 2001.

Fletcher, David. "The Parish Boundary: A Social Phenomenon in Hanoverian England." Rural History 14 (2003): 177-96.

Ford, Judy Ann. "The Autonomy of Conscience: Images of Confession in Mirk's Festial." Renaissance and Reformation 23, no. 3 (1999): 5-27.

_. John Mirk's "Festial": Orthodoxy, Lollardy and the Common People in Fourteenth-Century England. Cambridge: D. S. Brewer, 2006.

Fowler, J. T. "The Fifteen Last Days of the World in Medieval Art and Literature." Yorkshire Archaeological Journal 23 (1915): 313-37.

Frank, Robert Worth. "The 'Hungry Gap,' Crop Failure, and Famine: The Fourteenth-Century Agricultural Crisis and Piers Plowman." In Agriculture in the Middle Ages: Technology, Practice, and Representation, ed. Del Sweeney. 227-43. Philadelphia: University of Pennsylvania Press, 1995.

—_. "The Pardon Scene in Piers Plowman." Speculum 26, no. 2 (1951): 317-31.

_. "Piers Plowman" and the Scheme of Salvation. New Haven: Yale University Press, 1957.

Freccero, John. "The Firm Foot on a Journey without a Guide." In Dante: The Poetics of Conversion, ed. Rachel Jacoff. 29-54. Cambridge: Harvard University Press, 1986.

French, Katherine L. The Good Women of the Parish: Gender and Religion after the Black Death. Philadelphia: University of Pennsylvania Press, 2008.

. The People of the Parish: Community Life in a Late Medieval English Diocese. Philadelphia: University of Pennsylvania Press, 2001.

French, Katherine L., Gary Gibbs, and Beat Kümin, eds. The Parish in English Life, 1400-160o. Manchester: Manchester University Press, 1997.

Friar, Stephen. A Companion to the English Parish Church. Stroud: Alan Sutton, 1996. 
Friedman, John B. Northern English Books, Owners, and Makers in the Late Middle Ages. Syracuse: Syracuse University Press, 1995.

Galloway, Andrew. "The Making of a Social Ethic in Late Medieval England: From Gratitudo to 'Kyndenesse." Journal of the History of Ideas 55 (1994): 365-83.

—. The Penn Commentary on "Piers Plowman." Vol. 1, C Prologue_Passus 4; B Prologue-Passus 4, A Prologue-Passus 4. Philadelphia: University of Pennsylvania Press, 2006.

Garrison, Jennifer. "Mediated Piety: Eucharistic Theology and Lay Devotion in Robert Mannyng's Handlyng Synne." Speculum 85, no. 4 (2010): 894-922.

Gasquet, Francis Aidan. Parish Life in Mediaeval England. London: Methuen, 1907.

Gayk, Shannon. “'As Plouzmen Han Preued': The Alliterative Work of a Set of Lollard Sermons." Yearbook of Langland Studies 20 (2006): 43-65.

- Image, Text, and Religious Reform in Fifteenth-Century England. Cambridge: Cambridge University Press, 2010.

_. "The Present of Future Things: The Fifteen Signs of Judgment in Early England." In Alabaster Sculpture in Medieval England: A Reassessment, ed. Jessica Brantley, Elizabeth Teviotdale, and Stephen Perkinson. Kalamazoo: Medieval Institute Publications (forthcoming).

Geary, Patrick. Living with the Dead in the Middle Ages. Ithaca: Cornell University Press, 1994.

Gee, E. A. “The Painted Glass of All Saints' Church, North Street, York.” Archaeologia 102 (1969): 151-202.

Geertz, Clifford. The Interpretation of Culture. New York: Basic Books, 1973.

Gertsman, Elina. The Dance of Death in the Middle Ages: Image, Text, Performance. Turnhout: Brepols, 2010.

Gilchrist, Roberta. Norwich Cathedral Close: The Evolution of the English Cathedral Landscape. Woodbridge: Boydell, 2005.

Gill, Miriam. "Preaching and Image: Sermons and Wall Paintings in Later Medieval England." In Preacher, Sermon and Audience in the Middle Ages, ed. Catherine A. Muessig. 155-80. Leiden: Brill, 2002.

Gillespie, Vincent. "Design and Function of Some Pastoral Manuals." Leeds Studies in English 11 (1980): 36-58.

—. "Mystic's Foot: Rolle and Affectivity." In The Medieval Mystical Tradition in England, ed. Marion Glasscoe. 199-230. Exeter: Exeter University Press, 1982. Repr. in Vincent Gillespie. Looking in Holy Books: Essays on Late Medieval Religious Writing in England. 243-76. Turnhout: Brepols, 2011.

—. Vernacular Theology." In Middle English, ed. Paul Strohm. 401-20. Oxford: Oxford University Press, 2007.

Gittings, Claire. Death, Burial and the Individual in Early Modern England. London: Croom Helm, 1984.

Godden, Malcolm. "Plowmen and Hermits in Langland's Piers Plowman." Review of English Studies 35 (1984): 129-63.

Le Goff, Jacques. The Birth of Purgatory. Trans. Arthur Goldhammer. Chicago: University of Chicago Press, 1984.

Goldberg, P. J. P. "Lay Book Ownership in Late Medieval York: The Evidence of Wills." The Library 16 , no. 3 (1994): 181-89.

- Women, Work, and Lifecycle in a Medieval Economy: Women in York and Yorkshire, c. 1300-1520. Oxford: Clarendon Press, 1992. 
Graves, Pamela C. The Form and Fabric of Belief: An Archaeology of the Lay Experience of Religion in Medieval Norfolk and Devon. British Archaeological Reports Series 311. Oxford: Archaeopress, 2000.

. "Social Space in the English Medieval Parish Church." Economy and Society 18, no. 3 (1989): 297-322.

Gray, Douglas. "London, British Library Additional MS 37049-A Spiritual Encyclopedia." In Text and Controversy from Wyclif to Bale, ed. Helen Barr and Ann M. Hutchinson. 99-166. Turnhout: Brepols, 2005.

Gray, Madeleine. "Images of Words: Iconographies of Text and the Construction of Sacred Space in Medieval Church Wall Painting." In Sacred Text-Sacred Space: Architectural, Spiritual and Literary Convergences in England and Wales, ed. Joseph Sterrett and Peter Thomas. 13-34. Leiden: Brill, 2011.

Gray, Nick. "Langland's Quotations from the Penitential Tradition," Modern Philology 84, no. 1 (1986): 53-60.

Greenspan, Kate. "Lessons for the Priest, Lessons for the People: Robert Mannyng of Brunne's Audiences for Handlyng Synne." Essays in Medieval Studies 21 (2004): 109-21.

Grenville, Jane. Medieval Housing. London: Leicester University Press, 1997.

Griffith, David. "A Portrait of the Reader: Secular Donors and Their Books in the Art of the English Parish Church." In Imagining the Book, ed. Stephen Kelly and John J. Thompson. 209-35. Turnhout: Brepols, 2005.

Hanawalt, Barbara. "Peasant Women's Contribution to the Home Economy in Late Medieval England." In Women and Work in Preindustrial Europe, ed. Barbara Hanawalt. 3-19. Bloomington: Indiana University Press, 1986.

Hanna, Ralph. "'Meddling with Makings' and Will's Work." In Late Medieval Religious Texts and Their Transmission: Essays in Honour of A. I. Doyle, ed. A. J. Minnis. 85-94. Cambridge: D. S. Brewer, 1994.

__ "School and Scorn: Gender in Piers Plowman." New Medieval Literatures 3 (1999): 213-27. . "Will's Work." In Written Work: Langland, Labor, and Authorship, ed. Steven Justice and Kathryn Kerby-Fulton. 23-66. Philadelphia: University of Pennsylvania Press, 1997.

Harding, Vanessa. "Burial Choice and Burial Location in Later Medieval London." In Death in Towns: Urban Desponses to the Dying and the Dead, 100-160o, ed. Steven Bassett. 119-35. Leicester: Leicester University Press, 1992.

. The Dead and the Living in Paris and London, 1500-1670. Cambridge: Cambridge University Press, 2002.

—. "Space, Property and Propriety in Urban England." Journal of Interdisciplinary History 32 , no. 4 (2002): 549-69.

Haren, Michael J. "Friars as Confessors: The Canonist Background to the Fourteenth-Century Controversy." Peritia 3 (1984): 503-16.

Harksen, Sibylle. Women in the Middle Ages. New York: Abner Schram, 1975.

Harper, John. The Forms and Orders of Western Liturgy from the Tenth Century to the Eighteenth Century. Oxford: Clarendon Press, 1991.

Harvey, Nigel. A History of Farm Buildings in England and Wales. London: David and Charles, 1984.

Harwood, Britton J. "Langland's Kynde Wit." Journal of English and Germanic Philology 75, no. 3 (1976): 330-36. 
"Piers Plowman" and the Problem of Belief. Toronto: University of Toronto Press, 1992.

"The Plot of Piers Plowman and the Contradictions of Feudalism." In Speaking Two Languages: Traditional Disciplines and Contemporary Theory in Medieval Studies, ed. Allen J. Frantzen. 91-114. Albany: State University of New York Press, 1991.

Hasenfratz, Robert. "Terror and Pastoral Care in Handlyng Synne." In Texts and Traditions of Medieval Pastoral Care: Essays in Honour of Bella Millett, ed. Cate Gunn and Catherine Innes-Parker. 132-48. Woodbridge: York Medieval Press, 2009.

Heist, William H. The Fifteen Signs before Doomsday. East Lansing: Michigan State College Press, 1952.

Helmholz, R. H. "Excommunication in Twelfth-Century England." Journal of Law and Religion 11, no. 1 (1994-95): 235-53.

Hewett-Smith, Kathleen M., ed. William Langland's "Piers Plowman": A Book of Essays. New York: Routledge, 2001.

Hill, Ordelle G. The Manor, the Plowman, and the Shepherd: Agrarian Themes and Imagery in Late Medieval and Early Renaissance English Literature. Selinsgrove: Susquehanna University Press, 1993.

Hill, Thomas D. "Satan's Pratfall and the Foot of Love: Some Pedal Images in Piers Plowman A, B and C." Yearbook of Langland Studies 14 (2000): 153-62.

Hindle, Steve. "A Sense of Place? Becoming and Belonging in the Rural Parish, 1550-1650." In Communities in Early Modern England: Networks, Place, Rhetoric, ed. Alexandra Shepard and Phil Withington. 96-114. Manchester: Manchester University Press, 2000.

Hogg, James. An Illustrated Yorkshire Carthusian Religious Miscellany, British Library London Additional MS 37049. Vol. 3, The Illustrations. Analecta Cartusiana 95. Salzburg: Institut für Anglistik und Amerikanistik, 1981.

Holsinger, Bruce, ed. "Literary History and the Religious Turn.” Special issue, English Language Notes 44, no.1 (2006): 77-137.

Homans, George Caspar. English Villagers of the Thirteenth Century. New York: Russell and Russell, 1960.

Horner, P. J. "Preachers at Paul's Cross: Religion, Society, and Politics in Late Medieval England." In Medieval Sermons and Society: Cloister, City, University, ed. Jacqueline Hamesse. 261-82. Louvain-La-Neuve: Fédération Internationale des Instituts d'Etudes Médiévales, 1998.

Houlbrooke, Ralph. Death, Religion, and the Family in England, 1480-1570. Oxford: Clarendon, 1998.

Hughes, Andrew. Medieval Manuscripts for Mass and Office: A Guide to Their Organization and Terminology. Toronto: University of Toronto Press, 1982.

Hughes, Jonathan. "The Administration of Confession in the Diocese of York in the Fourteenth Century." In Studies in Clergy and Ministry in Medieval England, ed. David M. Smith. 87-163. York: Borthwick Institute, 1991.

Hutton, Ronald. The Stations of the Sun: A History of the Ritual Year in Britain. Oxford: Oxford University Press, 2001.

James, Mervyn. "Ritual, Drama, and Social Body in the Late Medieval Town." Past and Present $98(1983): 3-29$.

Johnston, Alexandra. "William Revetour, Chaplain and Clerk of York, Testator." Leeds Studies in English 29 (1998): 153-78.

Johnston, Alexandra F., and Margaret Dorrell. "The York Mercers and Their Pageant of Doomsday, 1433-1526." Leeds Studies in English n.s. 6 (1972): 10-35. 
Jones, Edward. "Langland and Hermits." Yearbook of Langland Studies 11 (1997): 67-86.

Jung, Jacqueline. "Beyond the Barrier: The Unifying Role of the Choir Screen in Gothic Churches." Art Bulletin 82 (2000): 622-57.

Jungmann, Josef. The Mass of the Roman Rite: Its Origins and Development. Trans. Francis A. Brunner. 2 vols. Westminster: Christian Classics, 1986.

Justice, Steven. Writing and Rebellion: England in 1381. Berkeley: University of California Press, 1994.

Kamerick, Kathleen. Popular Piety and Art in the Late Middle Ages: Image Worship and Idolatry in England, 1350-1500. New York: Palgrave, 2002.

Karnes, Michelle. Imagination, Meditation, and Cognition in the Middle Ages. Chicago: University of Chicago Press, 2011.

Katzenellenbogen, Adolf. Allegories of the Virtues and Vices in Mediaeval Art from Early Christian Times to the Thirteenth Century. New York: Norton, 1964.

Kay, Sarah. The Place of Thought: The Complexity of One in Late Medieval French Didactic Poetry. Philadelphia: University of Pennsylvania Press, 2007.

Keiser, George R. A Manual of the Writings in Middle English. Vol. 10, Works of Science and Information, ed. Albert E. Hartung. New Haven: Archon, 1967-.

- "Noght How Lang Man Lifs; Bot How wele': The Laity and the Ladder of Perfection." In De Cella in Seculum: Religious and Secular Life and Devotion in Late Medieval England, ed. Michael G. Sargent. 145-59. Cambridge: D. S. Brewer, 1989.

Kelly, J. N. D. The Athanasian Creed. New York: Harper and Row, 1964.

Kelly, Stephen, and John J. Thompson. "Imagined Histories of the Book: Current Paradigms and Future Directions." In Imagining the Book, ed. Stephen Kelly and John J. Thompson. 1-16. Turnhout: Brepols, 2005.

Kerby-Fulton, Kathryn. Reformist Apocalypticism and "Piers Plowman." Cambridge: Cambridge University Press, 1990.

Kermode, Jennifer. Medieval Merchants: York, Beverley, and Hull in the Later Middle Ages. Cambridge: Cambridge University Press, 1998.

Kinch, Ashby. "Affirmative Negation: The Affective Economy of Late Medieval Illustrations of the Office of the Dead." Anglistik 25, no. 1 (2014): 15-27.

King, Pamela. "York Plays, Urban Piety and the Case of Nicholas Blackburn, Mercer." Archiv für das Studium der neueren Sprachen und Literaturen 232 (1995): 37-50.

Kirk, Elizabeth D. "Langland's Plowman and the Recreation of Fourteenth-Century Religious Metaphor." Yearbook of Langland Studies 2 (1988): 1-21.

Knight, Stephen. “The Voice of Labour in Fourteenth-Century English Literature." In The Problem of Labour in Fourteenth-Century England, ed. James Bothwell, P. J. P. Goldberg, and W. M. Ormrod. 101-22. Woodbridge: York Medieval Press, 2000.

Konsmo, Erik. Pauline Metaphors of the Holy Spirit: The Intangible Spirit's Tangible Presence in the Life of the Christian. New York: Peter Lang, 2010.

Kuczynski, Michael P. Prophetic Song: The Psalms as Moral Discourse in Late Medieval England. Philadelphia: University of Pennsylvania Press, 1995.

Kümin, Beat. The Shaping of a Community: The Rise and Reformation of the English Parish $c$. 1400-1560. Aldershot: Scolar Press, 1996.

Kumler, Aden. Translating Truth: Ambitious Images and Religious Knowledge in Late Medieval France and England. New Haven: Yale University Press, 2011. 
Langdon, John. "Agricultural Equipment." In The Countryside of Medieval England, ed. Grenville Astill and Annie Grant. 86-107. Oxford: Basil Blackwell, 1988.

Lawler, Traugott. "Harlots' Holiness: The System of Absolution for Miswinning in the C Version of Piers Plowman." Yearbook of Langland Studies 20 (2006): 141-89.

—. "The Pardon Formula in Piers Plowman: Its Ubiquity, Its Binary Shape, Its Silent Middle Term." Yearbook of Langland Studies 14 (2000): 85-117.

Lewis, C. S. Studies in Words. Cambridge: Cambridge University Press, 1960.

Lewis, Robert E. "Medieval Popularity, Modern Neglect: The Case of the Pricke of Conscience." Fourteenth-Century English Mystics Newsletter 2, no. 4 (1976): 3-30.

Lewis, Robert E., and Angus McIntosh. A Descriptive Guide to the Manuscripts of the "Pricke of Conscience." Medium Aevum Monographs n.s. 12. Oxford: Society for the Study of Medieval Languages and Literatures, 1982.

Lindstrom, Bengt. "Two Descriptions of the Signs before the Last Judgment." Studia Neophilologica 48, no. 2 (1976): 307-11.

Little, Katherine C. Confession and Resistance: Defining the Self in Late Medieval England. Notre Dame: University of Notre Dame Press, 2006.

Little, Lester K. Benedictine Maledictions: Liturgical Cursing in Romanesque France. Ithaca: Cornell University Press, 1993.

Lochrie, Karma. Covert Operations: The Medieval Uses of Secrecy. Philadelphia: University of Pennsylvania Press, 1999.

MacKinnon, James. "Musical Instruments in Medieval Psalm Commentaries and Psalters." Journal of the American Musicological Society 21 (1968): 3-20.

Macy, Gary. "Commentaries on the Mass during the Early Scholastic Period." In Medieval Liturgy: A Book of Essays, ed. Lizette Larson-Miller. 25-59. New York: Garland, 1997.

Mann, Jill. Langland and Allegory. Morton W. Bloomfield Lectures on Medieval Literature 2. Kalamazoo: Medieval Institute Publications, 1992.

Mansfield, Mary. The Humiliation of Sinners: Public Penance in Thirteenth-Century France. Ithaca: Cornell University Press, 1990.

Marks, Richard. "Picturing Word and Text in the Late Medieval Parish Church." In Image, Text, and Church, 1380-160o: Essays for Margaret Aston, ed. Linda Clark, Maureen Jurkowski, and Colin Richmond. 162-202. Toronto: Pontifical Institute, 2009.

__. "Sir Geoffrey Luttrell and Some Companions: Images of Chivalry c. 1320-50." Wiener Jahrbuch für Kuntsgeschichte 46-47 (1993/94): 343-55.

—. Stained Glass in England during the Middle Ages. London: Routledge, 1993.

Mason, Emma "The Role of the English Parishioner, 1100-150o." Journal of Ecclesiastical History 27, no. 1 (1976): 17-29.

Matsuda, Takami. Death and Purgatory in Middle English Didactic Poetry. Woodbridge: D. S. Brewer, 1997.

Mercer, Eric. “'Domus Longa' and 'Long House.” Vernacular Architecture 3 (1972): 9-10.

Middleton, Anne. "Acts of Vagrancy: The C Version 'Autobiography' and the Statute of 1388." In Written Work: Langland, Labor, and Authorship, ed. Steven Justice and Kathryn KerbyFulton. 208-317. Philadelphia: University of Pennsylvania Press, 1997.

—. "Narration and the Invention of Experience: Episodic Form in Piers Plowman." In The 
Wisdom of Poetry: Essays in Early English Literature in Honor of Morton W. Bloomfield, ed. Larry D. Benson and Siegfried Wenzel. 91-122. Kalamazoo: Medieval Institute Publications, 1982.

Miles, Laura Saetveit. “The Origins and Development of the Virgin Mary's Book at the Annunciation." Speculum 89, no. 3 (2014): 632-69.

Millar, Edward G. The Luttrell Psalter: Two Plates in Colour and One Hundred and Eighty-Three in Monochrome from the Additional Manuscript 42130 in the British Museum. London: British Museum, 1932.

Miller, Mark. "Displaced Souls, Idle Talk, Spectacular Scenes: Handlyng Synne and the Perspective of Agency." Speculum 71, no. 3 (1996): 606-32.

Minnis, Alastair. "Piers's Protean Pardon: The Letter and Spirit of Langland's Theology of Indulgences." In Studies in Late Medieval and Early Renaissance Texts in Honour of John Scattergood, ed. Anne Marie D’Arcy and Alan J. Fletcher. 218-40. Portland: Four Courts Press, 2005.

Moger, Olive M., and Margaret E. Wood. “The Hundred of Dumpford.” In The Victoria History of the County of Sussex, ed. William Page. Vol. 4, The Rape of Chichester, ed. L. F. Salzman. 3-39. The Victoria History of the Counties of England. Oxford: Oxford University Press, for the Institute of Historical Research, 1953.

Morey, James H. "Legal and Spiritual Sanctuary in the Northern Homily Cycle and Piers Plowman B, XVII, 1-126." Journal of English and Germanic Philology 93 (1994): 326-35.

Morgan, Gerald. "The Meaning of Kind Wit, Conscience and Reason in the First Vision of Piers Plowman." In The Shaping of English Poetry: Essays on "Sir Gawain and the Green Knight," Langland, Chaucer, and Spenser, ed. Gerald Morgan. 63-74. Bern: Peter Lang, 2010.

Morgan, Nigel. "Patrons and Devotional Images in English Art of the International Gothic." In Reading Texts and Images: Essays on Medieval and Renaissance Art and Patronage in Honour of Margaret M. Manion, ed. Bernard J. Muir. 93-121. Exeter: Exeter University Press, 2002.

Morris, Colin. "Pilgrimage to Jerusalem in the Late Middle Ages." In Pilgrimage: The English Experience from Becket to Bunyan, ed. Colin Morris and Peter Roberts. 141-63. Cambridge: Cambridge University Press, 2002.

Mortlock, D. P. The Guide to Suffolk Churches. Cambridge: Lutterworth Press, 2009.

Nichols, Ann Eljenholm. "Books-for-Laymen: The Demise of a Commonplace." Church History 56, no. 4 (1987): 457-73.

. "The Etiquette of Pre-Reformation Confession in East Anglia." The Sixteenth Century Journal 17, no. 2 (1986): 145-63.

- Seeable Signs: The Iconography of the Seven Sacraments, 1350-1544. Woodbridge: Boydell, 1994.

O’Connor, David. E. “The Stained and Painted Glass.” In A History of York Minster, ed. G. E. Aylmer and Reginald Cant. 313-93. Oxford: Clarendon Press, 1977.

O’Mara, Veronica. “'Go, 3e Curselynges, to Euerlasting Fier': Doomsday in Middle English Prose Sermons." In Prophecy, Apocalypse and the Day of Doom: Proceedings of the Harlaxton Symposium, ed. Nigel Morgan. 277-91. Donington: Shaun Tyas, 2004.

. "The Last Judgment in Medieval English Prose Sermons: An Overview." In The Last Judgment in Medieval Preaching, ed. Thom Mertens, Maria Sherwood-Smith, Michael Mecklenberg, and Hans-Jochen Schiewer. 19-41. Turnhout: Brepols, 2013.

O'Reilly, Jennifer. Studies in the Iconography of the Virtues and Vices in the Middle Ages. New York: Garland, 1988. 
Orme, Nicholas. "The Charnel Chapel of Exeter Cathedral." In Medieval Art and Architecture at Exeter Cathedral, ed. Francis Kelley. London: British Archaeological Association, 1991.

Pantin, W. A. The English Church in the Fourteenth Century. South Bend: University of Notre Dame Press, 1962.

Paxson, James J. "Gender Personified, Personification Gendered, and the Body Figuralized in Piers Plowman." Yearbook of Langland Studies 12 (1998): 65-96.

- The Poetics of Personification. Cambridge: Cambridge University Press, 1994.

Pederson, Sarah. "Piety and Charity in the Painted Glass of Late Medieval York." Northern History 36 , no. 1 (2000): 33-42.

Penn, Simon A. C. "Female Wage-Earners in Late Fourteenth-Century England." Agricultural History Review 35 (1987): 1-14.

Pevsner, Nikolaus. The Buildings of England. Vol. 28, Suffolk, rev. ed. London: Penguin, 1974.

Pevsner, Nikolaus, and David Neave. The Buildings of England. Vol. 43, Yorkshire: York and the East Riding. London: Penguin, 1995.

Pickering, O. S. "Notes on the Sentence of Cursing in Middle English; or, a Case for the Index of Middle English Prose." Leeds Studies in English n.s. 12 (1981): 229-44.

Piehler, Paul. The Visionary Landscape: A Study in Medieval Allegory. Montreal: McGill Queen's University Press, 1971.

Pocock, J. G. A. "Texts as Events: Reflections on the History of Political Thought." In Politics of Discourse: The Literature and History of Seventeenth-Century England, ed. Kevin Sharpe and Steven N. Zwicker. 21-34. Berkeley: University of California Press, 1987.

Poleg, Eyal. "A Ladder Set Up on Earth': The Bible in Medieval Sermons." In The Practice of the Bible in the Middle Ages: Production, Reception, and Performance in Western Christianity, ed. Susan Boynton and Diane J. Reilly. 205-27. New York: Columbia University Press, 2011.

Powell, Susan. "All Saints' Church, North Street, York: Text and Image in the Pricke of Conscience Window." In Prophecy, Apocalypse and the Day of Doom: Proceedings of the Harlaxton Symposium, ed. Nigel Morgan. 292-316. Donington: Shaun Tyas, 2004.

_. "The Festial: The Priest and His Parish." In The Parish in Late Medieval England, ed. Clive Burgess and Eamon Duffy. 160-76. Donnington: Shaun Tyas, 2006.

Ragon, Michael. The Space of Death: A Study of Funerary Architecture, Decoration, and Urbanism. Trans. Alan Sheridan. Charlottesville: University of Virginia Press, 1983.

Randall, Lilian. Medieval and Renaissance Manuscripts in the Walters Art Gallery. Baltimore: Johns Hopkins University Press, 1989.

Raschko, Mary. “'To Be Worschipe of God and Profite of Peple': Lollard Sermons on the Parable of the Labourers in the Vineyard." In Wycliffite Controversies, ed. Mishtooni Bose and Patrick Hornbeck. 175-92. Turnhout, Belgium: Brepols, 2011.

Raskolnikov, Masha. Body against Soul: Gender and Sowlehele in Medieval Allegory. Columbus: Ohio State University Press, 2009.

Raymo, Robert R. A Manual of the Writings in Middle English. Vol. 7, Works of Religious and Philosophical Instruction, ed. Albert E. Hartung. New Haven: Archon, 1967-.

Rees Jones, Sarah, and Felicity Riddy. "The Bolton Hours of York: Female Domestic Piety and the Public Sphere." In Household, Women, and Christianities in Late Antiquity and the Middle Ages, ed. Anneke B. Mulder-Bakker and Jocelyn Wogan-Browne. 215-60. Turnhout: Brepols, 2005.

Reinert, Laura. "A Middle English Text on Planting and Grafting in Cambridge, Trinity College, 0.5.26." American Notes and Queries, n.s. 19 (2006): 9-16. 
Reynolds, Roger E. “The Drama of Medieval Liturgical Processions." Revue de Musicologie 86, no. 1 (2000): $127-42$.

Rice, Nicole. Lay Piety and Religious Discipline in Middle English Literature. Cambridge: Cambridge University Press, 2008.

Richmond, Colin. "Religion and the Fifteenth-Century Gentleman." In The Church, Politics, and Patronage in the Fifteenth Century, ed. R. B. Dobson. 193-208. Gloucester: Alan Sutton, 1984.

Roberts, Charlotte A. "Analysis of Some Human Femora from a Medieval Charnel House at Rothwell Parish Church, Northamptonshire, England." Ossa 9-11 (1982): 119-34.

Roberts, Michael. "Sickles and Scythes: Women's and Men's Work at Harvest Time." History Workshop 7 (1979): 3-28.

Robertson, D. W. “The Cultural Tradition of Handlyng Synne." Speculum 22, no. 2 (1947): 162-85.

Robertson, Kellie. The Laborer's Two Bodies: Literary and Legal Productions inBritain, 1350-1500. New York: Palgrave MacMillan, 2006.

. "Medieval Things: Materiality, Historicism, and the Premodern Object." Literature Compass 5 (2008): 1060-80.

Roffey, Simon. The Medieval Chantry Chapel: An Archaeology. Woodbridge: Boydell, 2007.

Rogers, Nicholas. "'Hic Iacet . . . : The Location of Monuments in Late Medieval Parish Churches." In The Parish in Late Medieval England, ed. Clive Burgess and Eamon Duffy. 261-77. Donnington: Shaun Tyas, 2006.

Root, Jerry. "Space to Speke": The Confessional Subject in Medieval Literature. New York: Peter Lang, 1997.

Rosewell, Roger. Medieval Wall Paintings in English and Welsh Churches. Woodbridge: Boydell and Brewer, 2008.

Royal Commission on Historical Monuments. An Inventory of the Historical Monuments in the City of York. Vol. 3, South-West of the Ouse. London: H. M. Stationery Office, 1962-68.

Rubin, Miri. Corpus Christi: The Eucharist in Late Medieval Culture. Cambridge: Cambridge University Press, 1991.

. "Small Groups: Identity and Solidarity in the Late Middle Ages." In Enterprise and Individuals in Fifteenth-Century England, ed. Jennifer Kermode. 132-50. Stroud: Alan Sutton, 1991.

Rutt, Richard. A History of Hand Knitting. Loveland: Interweave Press, 1987.

Sandler, Lucy Freeman. Gothic Manuscripts, 1285-1385. 2 vols. A Survey of the Manuscripts Illuminated in the British Isles 5. Oxford: Oxford University Press, 1986.

- Omne Bonum: A Fourteenth-Century Encyclopedia of Universal Knowledge from British Library MSS Royal 6 E VI-6 E VII. 2 vols. London: Harvey Miller, 1996.

- The Psalter of Robert de Lisle in the British Library. London: Harvey Miller, 1983.

"The Study of Marginal Imagery: Past, Present, and Future." Studies in Iconography 18 (1997): $1-49$.

- "The Word in the Text and the Image in the Margin: The Case of the Luttrell Psalter." The Journal of the Walters Art Gallery 54 (1996): 87-99.

Sargent, Michael G. "The Program of Illustration in National Library of Scotland, Advocates' Library MS 18.1.7 and New York, Pierpont Morgan Library MS 648 of Nicholas Love's Mirror of the Blessed Life of Jesus Christ." In Tributes to Kathleen L. Scott: English Medieval Manuscripts; Readers, Makers and Illuminators, ed. M. Villalobos Hennessey. 251-67. London: Harvey Miller, 2009. 
"What Do the Numbers Mean? A Textual Critic's Observations on Some Patterns of Middle English Manuscript Transmission." In Design and Distribution of Late Medieval Manuscripts in England, ed. Margaret Connolly and Linne R. Mooney. 205-44. York: York Medieval Press, 2008.

Scanlon, Larry. Narrative, Authority, and Power: The Medieval Exemplum and the Chaucerian Tradition. Cambridge: Cambridge University Press, 1994.

Scase, Wendy. "Piers Plowman" and the New Anticlericalism. Cambridge: Cambridge University Press, 1989.

—. "St. Anne and the Education of the Virgin: Literary and Artistic Traditions and Their Implications." In England in the Fourteenth Century, ed. Nicholas Rogers. Harlaxton Medieval Studies 3. 81-96. Stamford: P. Watkins, 1993.

Schemmann, Ulrike. Confessional Literature and Lay Education: The "Manuel de Pechez" as a Book of Good Conduct and Guide to Personal Religion. Düsseldorf: Droste, 2000.

Schroeder, M. C. “Piers Plowman: The Tearing of the Pardon.” Philological Quarterly 49 (1970): $8-18$.

Scott, Anne M. "For Lewed Men Vndyr Toke on Englyssh Tonge to Make This Boke: Handlyng Synne and English Didactic Writing for the Laity." In What Nature Does Not Teach: Didactic Literature in the Medieval and Early-Modern Periods, ed. Juanita Feros Ruys. 377-40o. Turnhout: Brepols, 2008.

Senior, Matthew. In the Grip of Minos: Confessional Discourse in Dante, Corneille, and Racine. Columbus: Ohio State University Press, 1994.

Shaw, Judith. "The Influence of Canonical and Episcopal Reform on Popular Books of Instruction." In Popular Literature of Medieval England, ed. Thomas J. Heffernan. 44-6o. Knoxville: University of Tennessee Press, 1985.

Simpson, James. "Piers Plowman": An Introduction to the B-Text. 2nd ed. Exter: Exeter University Press, 2007.

Smith, D. Vance. “Negative Langland." Yearbook of Langland Studies 23 (2009): 35-59.

Smith, Kathryn A. “Margin.” Studies in Iconography 33 (2012): 29-44.

Somerset, Fiona. “'Mark Him Wel for He Is On of Do': Training the 'Lewed' Gaze to Discern Hypocrisy.” English Literary History 68, no. 2 (2001): 315-34.

Stanbury, Sarah. The Visual Object of Desire in Late Medieval England. Philadelphia: University of Pennsylvania Press, 2008.

Steiner, Emily. Documentary Culture and the Making of Medieval English Literature. Cambridge: Cambridge University Press, 2003.

—. Reading "Piers Plowman." Cambridge: Cambridge University Press, 2013.

Stevens, John. "Dante and Music." Italian Studies 23 (1968): 1-18.

Stevenson, Jill. Performance, Cognitive Theory, and Devotional Culture: Sensual Piety in Late Medieval York. New York: Palgrave, 2010.

Stock, Brian. The Implications of Literacy: Written Language and Models of Interpretation in the Eleventh and Twelfth Centuries. Princeton: Princeton University Press, 1983.

Strange, William. "The Willful Trope: Some Notes on Personification with Illustrations from Piers (A).” Annuale Medievale 9 (1968): 26-39.

Strohm, Paul. "Afterword: What Happens at Intersections?” In Bodies and Disciplines: Intersections of Literature and History in Fifteenth-Century England, ed. David Wallace and Barbara Hanawalt. 223-32. Minneapolis: University of Minnesota Press, 1996. 
- Hochon's Arrow: The Social Imagination of Fourteenth-Century Texts. Princeton: Princeton University Press, 1992.

Sullivan, Matthew. "The Author of the Manuel des Péchés." Notes and Queries 38, no. 2 (1991): $155-57$.

"A Brief Textual History of the Manuel des Péchés." Neuphilologische Mitteilungen 93 (1992): 337-46.

Swanson, R. N. Church and Society in Late Medieval England. Oxford: Blackwell, 1989.

__. "The Origins of the Lay Folks' Catechism." Medium Aevum 60 (1991): 92-100.

. "Prayer and Participation in Late Medieval England." Studies in Church History 42 (2006): $130-38$.

—. Religion and Devotion in Europe, c. 1215-1515. Cambridge: Cambridge University Press, 1995.

Szittya, Penn R. The Antifraternal Tradition in Medieval Literature. Princeton: Princeton University Press, 1986.

Tambling, Jeremy. Confession: Sexuality, Sin, and the Subject. Manchester: Manchester University Press, 1990.

Tanner, Norman, and Sethina Watson. "Least of the Laity: The Minimum Requirements for a Medieval Christian." Journal of Medieval History 32 (2006): 395-423.

Tentler, Thomas N. Sin and Confession on the Eve of the Reformation. Princeton: Princeton University Press, 1977.

Thiery, Daniel. Polluting the Sacred: Violence, Faith and the "Civilizing" of Parishioners in Late Medieval England. Leiden: Brill, 2009.

Thirsk, Joan. "The Common Fields." Past and Present 29 (1964): 3-25.

Tillot, P. M. “The Parish Churches." In The Victoria History of the Counties of England: A History of Yorkshire; The City of York, ed. P. M. Tillot. 365-404. The Victoria History of the Counties of England. Oxford: Oxford University Press, for the Institute of Historical Research, 1961.

Tristram, Ernest William. English Wall Painting of the Fourteenth Century. London: Routledge and Kegan Paul, 1955.

Trudel, Guy. "The Middle English Book of Penance and the Readers of the Cursor Mundi." Medium Aevum 74, no. 1 (2005): 10-33.

Vale, Malcom G. A. "Piety, Charity and Literacy among the Yorkshire Gentry, 1370-1480." Borthwick Papers 50 (1976): 1-32.

Varnam, Laura. "Church." In A Handbook of Middle English Studies, ed. Marion Turner. 299-314. Malden: John Wiley and Sons, 2013.

Vauchez, André. The Laity in the Middle Ages: Religious Beliefs and Devotional Practices. Ed. Daniel E. Bornstein. Trans. Margery J. Schneider. Notre Dame: University of Notre Dame Press, 1993.

Vitz, Evelyn Birge. "Liturgical versus Biblical Citation in Medieval Vernacular Literature." In Tributes to Jonathan J. G. Alexander: The Making and Meaning of Illuminated Medieval and Renaissance Manuscripts, Art and Architecture, ed. Susan L'Engle and Gerald B. Guest. 44349. London: Harvey Miller, 2006.

Wailes, Stephen L. Medieval Allegories of Jesus' Parables. Berkeley: University of California Press, 1987.

Walsh, Katherine. "Archbishop FitzRalph and the Friars at the Papal Court in Avignon, 1357-60." Traditio 31 (1975): 223-45. 
A Fourteenth-Century Scholar and Primate: Richard FitzRalph in Oxford, Avignon, and Armagh. Oxford: Clarendon Press, 1981.

Walters, H. B. Church Bells of England. London: Oxford University Press, 1912.

Warner, Lawrence. The Lost History of "Piers Plowman": The Earliest Transmission of Langland's Work. Philadelphia: University of Pennsylvania Press, 2011.

Watson, Nicholas. "Censorship and Cultural Change in Late Medieval England: Vernacular Theology, the Oxford Translation Debate, and Arundel's Constitutions of 1409." Speculum 70, no. 4 (1995): 822-64.

Weldon, James F. G. "Gesture of Perception: The Pattern of Kneeling in Piers Plowman B. 18-19." Yearbook of Langland Studies 3 (1989): 49-66.

Wenzel, Siegfried. “Medieval Sermons." In A Companion to "Piers Plowman,” ed. John A. Alford. 155-72. Berkeley: University of California Press, 1988.

—. “The Pilgrimage of Life as a Late Medieval Genre." Mediaeval Studies 35 (1973): 370-88.

- The Sin of Sloth: Acedia in Medieval Thought and Literature. Chapel Hill: University of North Carolina Press, 1967.

White, Hugh. Nature and Salvation in "Piers Plowman." Cambridge: D. S. Brewer, 1988.

Wieck, Roger S. “The Death Desired: Books of Hours and the Medieval Funeral.” In Death and Dying in the Middle Ages, ed. Edelgard E. DuBruck and Barbara I. Gusick. 431-80. New York: Peter Lang, 1999.

- Painted Prayers: The Book of Hours in Medieval and Renaissance Art. New York: George Braziller, 1997.

- Time Sanctified: The Book of Hours in Medieval Art and Life. New York: George Braziller, 1988.

Williams, Arnold. "Relations between the Mendicant Friars and the Secular Clergy." Annuale Medievale 1 (1960): 22-95.

Williams, David J. Paul's Metaphors: Their Context and Character. Peabody: Hendrickson Publishers, 1999.

Winston-Allen, Anne. Stories of the Rose: The Making of the Rosary in the Middle Ages. University Park: Pennsylvania State University Press, 1997.

Wood, Sarah. Conscience and the Composition of "Piers Plowman." Oxford: Oxford University Press, 2012.

Woodcock, Alex. "Social and Symbolic Space in the Late Medieval Parish Church: An Archaeology of All Saints, North Street, York.” MA thesis, University of York, 1996.

Woods, Marjorie Curry, and Rita Copeland. "Classroom and Confession." In The Cambridge History of Medieval English Literature, ed. David Wallace. 376-406. Cambridge: Cambridge University Press, 1999.

Woolf, Rosemary. “The Tearing of the Pardon." In "Piers Plowman”: Critical Approaches, ed. S. S. Hussey. 50-75. London: Methuen, 1969.

Wormald, Francis. "Some Popular Miniatures and Their Rich Relations." In Miscellanea pro Arte: Hermann Schnitzler zur Vollendung des 6o. Lebensjahres am 13 Januar 1965. 279-85. Düsseldorf: L. Schwann, 1965.

Wright, Rosemary Muir. "Introducing the Medieval Psalter." In Studies in the Illustration of the Psalter, ed. Brendan Cassidy and Rosemary Muir Wright. 1-11. Stamford: Shaun Tyas, 2000. 
Wrightson, Keith. "Mutualities and Obligations: Changing Social Relationships in Early Modern England." Proceedings of the British Academy 139 (2006): 157-94.

Zeeman, Elizabeth. "Piers Plowman and the Pilgrimage to Truth." Essays and Studies 11 (1958): $1-16$.

Zeeman, Nicolette. "The Condition of Kynde." In Medieval Literature and Historical Inquiry: Essays in Honor of Derek Pearsall, ed. David Aers. 1-30. Woodbridge: D. S. Brewer, 2000.

. "Piers Plowman" and the Medieval Discourse of Desire. Cambridge: Cambridge University Press, 2006.

Zieman, Katherine. Singing the New Song: Literacy and Liturgy in Late Medieval England. Philadelphia: University of Pennsylvania Press, 2008. 


\section{INDEX}

Aers, D., 86n117

agriculture: as communal labor, 107, 116; and liturgy, 98-99; as metaphor for spiritual community, 23 , 82-83, 91-92, 94-120, 150, 153. See also grafting; harvest; horticulture; labor

Alighieri, Dante, 73, 130

Allen, E., 46n 48

alms, giving of, 21, 81-82, 87, 128. See also charity

Ambulate sermons, 73-76, 82, 86-88. See also sermons; walking

Anne, Saint, 141-43

Antichrist (in Piers Plowman), 59

apocalypse: signs of, 122-26, 133-34, 137,148 ; and spiritual community, 132-33. See also Last Judgment

Arundel, Thomas, 3, 148

Ashley, K., 67

Athanasian Creed, 103, 106, 108, 120.

See also salvation

Augustine, Saint, 6, 64, 72-73, 75-76, 82,92

Ault, W. O., 110, 111, 118, 119 avarice, and charity, 81-82. See also Seven Deadly Sins

Backhouse, J., 95n15

Banks, R., $65 n 3$

baptism, 8-9, 12-17; and burial, 11, 29-32; and community, 13-17, 31-32, 104; as contract, 33, 102; and naming, 13; and penitence, 93; and salvation, 13, 15-17, 37, 55; spatial aspects of, 12-13. See also burial; churchyards; fonts, baptismal

Bardsley, S., $113 n 84$

Barnwell, P. S., 144

Barr, H., 3n9, 57 n104

bede roll, 62

Bennett, H. S., 14n22

Benson, C. D., 5n24, $90 n 127$

Bernard of Clairvaux, 76-77, 92

Binski, P., 3n1o

Biscoglio, F., 115-16n97

Blackburn Window (York), 142-44

Bond, F., 25n 62 
books of hours, 19, 109, 143, 145, 152

Bossy, J., 14, 36n6, 120

boundaries, violation of, 53-55. See also gates; threshold

Briggs, C., 146n91

Brown, P., 2

Bryan, J., 4

Burgess, C., 17, 138n6o, 144n81

burial: anonymous, 24-25, 41; and baptism, $11,15,29-32$; ceremony of, 26, 79; in charnels, 24-25; exclusion from, 16-17, 35 ; in friaries, 10-11, 60-62; by kynde, 29-32; as memorial, 100, 144; in the parish, 11, 23, 29, 31; in Piers Plowman, 10-11, 29-32; rights of, 23. See also baptism; churchyard

Bushnell, R., 58

bylaws, village, 102, 110-12; and charity, 119; and community, 119; creation of, 118-19

Camille, M., 95n17, 97, 101n36

canon 21 (Fourth Lateran Council), 35-36, $45,48,54$

Carruthers, M., 75-76, 84, 86

catechism, 41-42, 72, 85. See also instruction

chapels, private, $144-45$

charity: and avarice, $81-82$; as call to action, 72; definitions of, 70-71; and labor, 92; in the Mass, 71; opposed to sloth, 76-77; and patronage, 141; and salvation, 88-90, 104, 106; and the space of the church, 71; and village bylaws, 119; and walking, 64-65, 72-75, 84, 87. See also good works

Chaucer, Geoffrey, 1n1, 56n94, 76-77, 83, 120

Chickering, H., 126

Church of All Saints, North Street (York), 7, 122-26, 134, 153. See also Blackburn Window; Corporal Works of Mercy Window; Prick of Conscience Window

Church of St. Andrew, Irnham (Lincolnshire), 100-101

Church of St. George, Trotton (West Sussex), 88-90, 105

churchyards: as final resting places, 22, 41; gates of, 47-48; misuse of, 26-28, 119; as porous, 52-53; as shared spaces, 6 , $23-24,28$; as sites of reciprocity, 17-28; as thresholds, 50-51, 63. See also burial; community; space

Ciabbatoni, F., $130 n 38$

Clanchy, M. 143n73

communion, 34-35; and confession, 48-49; at Easter, 40-41, 69. See also sacraments community: and baptism, 32, 104; and bylaws, 119; and confession, 39; household as, 95-96; and labor, 94-101, 107, 110-12, 116, 120; and the Mass, 120; parish as, 1, $11,26,41,125-27,138$; and processions, 66-69; and salvation, 2-6, 14, 63, 65, 67, 94, 109, 119-20, 149-54

confession: as collective parochial enterprise, 6, 33-46; and communion, 49; and Easter, 93-94; failed, 54-55, 60, 63; heard by friars, 34-35, 55-63; heard by parish priests, 35, 39, 48-49; in Handlyng Synne, 45-53; individual, 35-36; and Mass, 34, 37-41; in Piers Plowman, 5354, 85; as rejection of the devil, 47-49, 53; spatial dimensions of, $37-38$; virtues of, 46,48 ; ; visual depictions of, 37

Confiteor (prayer), 6, 37-41, 45-46, 138

Conscience (Piers Plowman), 30, 53-54, 85, 113

contracts: agricultural, 106, 108-9; baptism as, 102; spiritual, 33, 106

Corporal Works of Mercy, 72, 88-90, 102, 104-5, 141

Corporal Works of Mercy Window (York), 139-41

Crassons, K., 139

creation, of the world, 98

Cullum, P., 72 n34

Dancers of Colbek, $17 \mathrm{n}$

Davies, J. G., 12n

Davis, N. Z., 26n

Davlin, M., 137

De profundis, 18-19, 32, 150

dead: as forming community with the living, $1,11,15,18-21,24-26,29,32,39$, $62,126-28,151$; prayers for, $18-21,128$; 
resurrection of, 21, 22-23. See also baptism; burial; churchyards; community; Purgatory

dedications, of churches, 65

devil: blinding of, 46-49; struggle against, 6 , 34, 46-49, 67-70. See also sin

Dolan, T. P., $56 \mathrm{n} 98$

Donaldson, E. T., 30

dragons, in Rogation processions, 67-68

Duffy, E., 2, 62, 66, 144n81, 145, 152

Dyas, D., 83 n94

Dyer, C., 110n71, 111, 112n81, 118

Easter: communion on, 35, 40-41, 69; and confession, 93-94; and penance, 65-66, 69; processions on, 69, 73

education. See instruction

Edwards, A., 146

Elich, T., 37

Emmerson, R., 94n13, 95n16, 99, 10on34

Eucharist. See communion; sacraments

even-Cristen, behavior towards, 4, 32, 71, 106, 120. See also charity; community; neighbors

exclusion: ceremonies of, $42-44$; of the devil, $47-48$; from burial, $16-17,25-26$; from the church, 41-44; from communion, 40 ; from the parish community, 25-26; from salvation, 79-80, 109

excommunication, 41-44

fear: as spur to salvation, 126-27, 133-34, 138, 147. See also Last Judgment; Prick of Conscience

feet: as symbol of love, $64,72,75$; as symbol of $\sin , 80-83$. See also processions; walking

Festial (Mirk), 5, 6, 17-18, 21-24, 40-41, 44, 66-70, 150. See also Mirk, John; sermons

Finke, L., 84, 86n116

Fitzgibbons, M., 14n19, 132

FitzRalph, Richard, 56-57

fonts, baptismal, 5-6, 12-17, 149; as artworks, 12; spatial aspects of, 29-30. See also baptism
Ford, J., $5 \mathrm{n} 2 \mathrm{O}$

Foucault, M., 34

Freccero, J., 73, 76n59

French, K., 2, 44n43, 115

Friar, S., 25n6o

friars: and burial, 10-11, 61-62; confession heard by, 34-35, 55-63, 59-60; suspicion of, 31, 34-35, 53-63

Galloway, A., 9, 28n72

Garrison, J., 46n49

gates, metaphorical significance of, 84 . See also boundaries; thresholds

Gayk, S., 133n5o, 146n87

Geary, P., 65n2

Gee, E. A., 147

Geertz, Clifford, 3n9

General Sentence, 34, 41-45

Gerson, Jean, 37

Gill, M., 147

Gillespie, V., 3n11, 73n46, 147

gleaning, 110-12. See also agriculture; harvest godparents, 14-16

Goldberg, P. J. P., 94n13, 95n16, 99, 10on34

Golden Legend, 18-19, 122

good works, and salvation, 77, 81-83, 103-6, 126. See also charity; Corporal Works of Mercy

grafting, as metaphor, 34-35, 56-62. See also agriculture; harvest; horticulture; labor

Graves, P., 66n5, 144

Gray, M., 146

Gregory the Great, 76, 92, 146

Grenville, J., 23n

Hanawalt, B., 110

Handlyng Synne (Mannyng), 5-6, 15-17, $21-23,25,28,31,34,45-53,63,78,119,150$

Hanna, R., 9n, 52n

Harding, V., 23n51, 24n54, 28n74

harvest, 106-112, 116-21; Last Judgment as, 23, 97; as metaphor for salvation, 108, 
121; in the Luttrell Psalter, 94-101; in Piers Plowman, 101-3, 106-12, 116-21; regulations concerning, 102, 110-12, 116-18. See also agriculture; grafting; horticulture

Harwood, B., $87 n 119$

Hasenfratz, R., 46n5o

heaven: as community, 1, 125, 130, 147; depictions of, 126, 130, 137; ladder to, 77; and liturgy, 125, 131; and the parish, 39. See also Last Judgment; salvation

Heidegger, Martin, 13

hell, 17, 103, 109, 132; depictions of, 126, 130, 137; sounds of, 130, 132. See also devil; Last Judgment; Prick of Conscience

hermits, 46-47, 50-53, 80

Holy Church (Piers Plowman), 8-12, 29, 83-84, 91

horticulture, as metaphor, 56-62. See also agriculture; grafting; harvest; labor

Homans, G., 93

identity, parochial, 2, 6, 9, 11, 29-30, 32, 68, 149. See also community

images, and texts, 128-29, 145-47

instruction: catechetical, 72, 85, 104-5; lay, 2, 45-46; liturgical, 41-42, 66; and reading, 45, $143-46$

Instructions for Parish Priests (Mirk), 42, 72

Jacob's Well, 13, 77, 79-83

Jones, E., 52n72

Jung, J., 44n43

Justice, S., 68

Kamerick, K., 5n23

Kane, G., 30

Kay, S., $10 n 8$

Kelly, S., 146n91

Kempe, Margery, 52n72, 55n89

Kerby-Fulton, K., 56

King, P., $141 n 69$

Kinship, 13-14. See also community; kynde
Kuczynski, M., 72n41, 131n

Kümin, B., 1 n1

kynde, 6; and burial, 10-11, 29-32; meanings of, 28

labor: agricultural, 91-93; and charity, 92; communal, 101, 107, 110-12, 116-20; and the Last Judgment, 101-2; and liturgy, 98-100; as metaphor, 6-7; as penance, 91-92; and salvation, 116; as spiritual enterprise, 94, 97; and walking, 87; by women, 110-16; and worship, 97. See also agriculture; gleaning; harvest; horticulture

ladder, as metaphor, 73, 77. See also procession; walking

Langland, William. See Piers Plowman

Last Judgment: depiction of, 4, 11, 14, 21-23, 44-45, 88-90, 105-6, 109-10, 120, 133, 137-39, 147, 150; and good works, 88-90, 104; as harvest, 23, 97; and labor, 101-2; and sloth, 78; theology of, 103. See also heaven; hell; salvation

Lateran Council, Fourth (1215), 4, 9n4, 34-37, 40, 46, 56. See also canon 21

Lawler, T., $102 \mathrm{n} 37$

Lay Folks Mass Book, 5, 38-39, 88, 138

Lay Folks' Catechism, 70

literacy. See instruction; reading

Little, K., 46n 48

liturgy: and agricultural labor, 98-100; and the baptismal font, 12; and heaven, 125, 131; and music, 131-32; processions, 65-66. See also Mass

Lochrie, K., 36n6

longhouse, parish as, 22-23. See also agriculture

Luttrell, Geoffrey, 95, 99-101

Luttrell Psalter, 7, 91-92, 94-101, 113

Mann, J., 86n116

Mannyng, Robert. See Handlyng Synne

Mansfield, M., 36

Manuel des Péchés, 45, 51-52. See also Handlyng Synne 
Marks, R., 148

Mary (Mother of Jesus), 39, 42, 115, 141-43

Mass: and charity, 71; and community, 114, 120; and confession, 34, 37-41; efficacy of, 21; and Purgatory, 19-21, 128. See also communion; liturgy

Matthew, Gospel According to, 93, 104-6, 114,139

Meed (Piers Plowman), 60-63

Mercer, E., 23n49

Middleton, A., 9n3, 83n96

Miller, M., 46n48

Minnis, A., 102, 107n61

Mirk, John. See Festial; Instructions for Parish Priests

Morey, J., 5n21

Mortlock, D. P., 25n61

music: and liturgy, 131; in the Prick of Conscience, $130-31$

neighbors, love of, 70-71, 133. See also charity; community; even-Cristen

Nichols, A., 13n17, 37n11

Northern Homily Cycle, 6, 7, 92-94, 97, 101, 103-4. See also sermons

O'Mara, V., 124n3, 138

Office of the Dead, 19, 100, 109, 152

Omne Bonum, 37n12, 43-45

Palm Sunday: liturgy of, 55; procession on, $40,45,55,66-67$

Pantin, W. A., 4

pardon, in Piers Plowman, 102-3, 106-8, 112, $116,120-21$

patronage, religious, 60-63, 95, 99-101, 124-25, 139, 141, 143-45, 153. See also Blackburn Window; charity; Corporal Works of Mercy Window; friars; Luttrell Psalter; Prick of Conscience Window

Paul, Saint, writings of, 55n92, 71, 72, 75

Paxson, J., 10 8

penance, $6,19,33-63,87,104$; and baptism,
93-94; and charity, 107; communal, 33 , 37-40, 43-5, 107, 149-50; and Easter, 69, 93-94; and healing, 54, 82; and parochial space, 37-38; processions as expression of, 40-41, 67; and salvation, 43-44, 107, 112; work as, 91-92

Penetrans Domos (Piers Plowman), 53-55, 58. See also friars, suspicion of

Pevsner, N., 25n61

Pickering, O. S., 41-42n31

Piers Plowman, 4-8, 29-35, 53-54, 58-63, 78, 83-87, 91-92, 101-2, 149-50; agricultural labor in, 101-3, 106-18; female labor in, 112-16; pardon in, 102-3, 106-8, 112, 116, 120-21; pilgrimage in, 85-86, 107; wandering in, 31. See also Conscience; Holy Church; Meed; Penetrans Domos

pilgrimage: distinguished from walking, 64-65, 73-74, 85-87; in Piers Plowman, $85-86,107$

Pocock, J. G. A., 3n9

Powell, S., 40n27, 124n5, 125n11, 139n64

Prick of Conscience, 5, 7, 14, 21, 33, 80-81, 124-25, 126-33, 144-48; popularity of, 124-25; use of fear in, 126-27

Prick of Conscience Window, 7, 122-26, 133-34, 141, 144-45, 148, 150; creation of, 124-25, 139

priests: and confession, $35-39,48-49,56-57$; as doctors, 35-37, 54, 57; failures by, 35 , 40; as farmers, 7, 92, 98; parochial, 2, 30, 35-36, 45-46, 49, 56-57; and parochial space, 49

processions: dedicatory, 55; and Easter, 65-66, 69-70, 73; as expression of community, 66-68; as liturgical instruction, 66; for Palm Sunday, 40, 45, 55, 66-67; parochial, 65-70, 73; and penitence, 40-41, 67; for Rogation, 67-69, 88

Psalm 88, 130-31

Psalm 94, 98-100

Psalm 95, 98

Psalm 97, 98-99

psalms, reading of, 97-101

Purgatory: proximity of, 19-21; and reciprocity, 17-21, 126-30; and sloth, 78. See also reciprocity, of the dead and the living 
Raschko, M., 93n11

reading, 143-46. See also instruction; psalms, reading of

reciprocity, of the dead and the living, 1, 11, $15,17-21,24-25,29,32,39,62,126-28$, 151. See also community

reeves, function of, 116-18, 120-21. See also agriculture

Rice, N., 4, 147

Richmond, C., 152

ritual, in the parish, 4-5, 10, 30, 66, 88. See also baptism; burial; Mass; liturgy; processions

Robertson, K., 13

Rogationtide, 65, 67-69, 88

Rogers, N., 23n53

Rubin, M., 36n6, 67n12

sacraments, in the parish, 6, 9, 15, 23, 37, 46 . See also burial; communion; confession; friars; priests

salvation: and baptism, 13-17, 37, 55; and charity, 88-90, 106-7; as communal enterprise, 2-6, 14, 63, 65, 67, 94, 109, 119-20, 149-54; fear as spur to, 126, 138; and good works, 77, 81-83, 103-6, 126; harvest as metaphor for, 108, 121; and labor, 116; and penance, 37, 43-44, 107, 112; and walking, 64-65, 70, 73-77, 83-90. See also heaven; Last Judgment

Sandler, L., 44n42, 94n13, 98n22

Sargent, M., 67n11, 124-25

Sarum Rite, 12, 14

Scanlon, L., 46n

Scase, W., 30, 52n, 59, 143n

Schemmann, U., 22n

Schmidt, A. V. C., 31n, 61

Scott, A., 46n 48

sermons, 2-3, 6, 17, 66-67, 73-74, 77, 88, 92-93, 103-4, 147. See also Ambulate sermons; Festial; Handlyng Synne

Seven Deadly Sins, 58, 69-71, 81, 85, 88, 105

Simmons, T. F., 39n22

Simpson, J., 9 n 4 sin: avoidance of, 45-53, 64-65, 67-68, 88, 126; concealment of, 54 ; and feet, $80-83$; and inaction, 75. See also Seven Deadly Sins

sloth, 76-81; feet of, 81 ; as obstacle to salvation, 79-80; as opposed to charity, 76-77; and Purgatory, 78

Smith, D. V., 10

Sodom, destruction of, 134

Somerset, F., $49 n 60$

sowing, 112-16; linked with sewing, 113-15. See also agriculture; horticulture; labor space: and confession, $37-38$; in the parish church, 1, 9-11, 29-30, 34-35, 41, 44-45, 49-50, 71; and priests, 49

Speculum Sacerdotale, 24, 40, 66, 68-69

stained glass, 122, 133-48

Stevenson, J., 138n61

Stock, B., 146

Strohm, P., 3

Swanson, R. N., 38n19, 41, 7on27-28

Tanner, N., 14n21

Ten Commandments, $85-88$, 119. See also catechism

Tentler, T., 36

theology, vernacular, 3-4, 147-48

Thompson, J., 146n91

Thoresby, John, 9, 70-71

threshold: churchyard as, 47-49; symbolic value of, 6, 34. See also boundaries

Torre, James, 141

Truth (Piers Plowman), 84-85, 87, 107, $113-14,117$

vineyard, as metaphor, 104; parable of, 93. See also agriculture; harvest; horticulture; labor

Vitz, E., 12 n12

walking: and avoidance of sin, 69-71; and charity, 72-75, 84, 87; distinguished from pilgrimage, 64-65, 73-74, 85-87; and Easter, 65-66, 69-70, 73; and labor, 
87; as metaphor, $6-7,47-48,64-65,150-$ 51; and salvation, $64,70,73-77,83-90$ wall paintings, 4, 11, 14, 21, 88-90, 105, 147 wandering: of friars, 57; in Piers Plowman, 31,83

Watson, N., 3

Watson, S., 14n21

Wenzel, S., 73n 45

What the Church Betokeneth, 153-54

Wieck, W., 26n66

William of Shoreham, 73

Woodcock, A., 144n82 work. See labor

worship: collective, 2, 4-6, 100-101, 126-27, 138, 145, 147, 149, 151; and labor, 97. See also community; Mass

Wrath (Piers Plowman), 58-59

York Corpus Christi Plays, 105-6, 139

Zeeman, E., 83n94

Zeeman, N., 29n75, 151n3

Zieman, K., 131n40, 143n73 


\section{INTERVENTIONS: NEW STUDIES IN MEDIEVAL CULTURE}

\section{Ethan Knapp, Series Editor}

Interventions: New Studies in Medieval Culture publishes theoretically informed work in medieval literary and cultural studies. We are interested both in studies of medieval culture and in work on the continuing importance of medieval tropes and topics in contemporary intellectual life.

\section{Imagining the Parish in Late Medieval England} ELLEN K. RENTZ

Truth and Tales: Cultural Mobility and Medieval Media EDITED BY FIONA SOMERSET AND NICHOLAS WATSON

Eschatological Subjects: Divine and Literary Judgment in Fourteenth-Century French Poetry J. M. MOREAU

Chaucer's (Anti-)Eroticisms and the Queer Middle Ages TISON PUGH

Trading Tongues: Merchants, Multilingualism, and Medieval Literature JONATHAN HSY

Translating Troy: Provincial Politics in Alliterative Romance ALEX MUELLER

Fictions of Evidence: Witnessing, Literature, and Community in the Late Middle Ages JAMIE K. TAYLOR

Answerable Style: The Idea of the Literary in Medieval England EDITED BY FRANK GRADY AND ANDREW GALLOWAY

Scribal Authorship and the Writing of History in Medieval England MATTHEW FISHER

Fashioning Change: The Trope of Clothing in High-and Late-Medieval England ANDREA DENNY-BROWN

Form and Reform: Reading across the Fifteenth Century EDITED BY SHANNON GAYK AND KATHLEEN TONRY

How to Make a Human: Animals and Violence in the Middle Ages KARL STEEL

Revivalist Fantasy: Alliterative Verse and Nationalist Literary History RANDY P. SCHIFF

Inventing Womanhood: Gender and Language in Later Middle English Writing TARA WILLIAMS

Body Against Soul: Gender and Sowlehele in Middle English Allegory MASHA RASKOLNIKOV 